\title{
A atuação política da agência de informação dos Estados Unidos no Brasil (1953-1964)
}

\author{
Fernando Santomauro
}

SANTOMAURO, F. A atuação política da Agência de Informação dos Estados Unidos no Brasil (1953-1964) [online]. São Paulo: Editora UNESP; São Paulo: Cultura Acadêmica, 2015, 354 p. ISBN 978-85-7983-705-0. Available from SciELO Books $<$ http://books.scielo.org $>$.

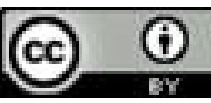

All the contents of this work, except where otherwise noted, is licensed under a Creative Commons Attribution 4.0 International license.

Todo o conteúdo deste trabalho, exceto quando houver ressalva, é publicado sob a licença Creative Commons Atribição $\underline{4.0}$.

Todo el contenido de esta obra, excepto donde se indique lo contrario, está bajo licencia de la licencia Creative Commons Reconocimento 4.0. 
A ATUaÇÃo POLÍtica da AgÊnCIA de InFORMAÇÃo DOS EsTAdos Unidos NO BRASIL (1953-1964) 
Conselho Editorial Acadêmico responsável por esta publicação

Samuel Alves Soares

Suzeley Kalil Mathias Flávia de Campos Mello

Sebastião Velasco e Cruz 
FERNANDO SANTOMAURO

A atuação POlítica DA AgÊnCia de INFORMAÇÃO DOS ESTADOS UNIDOS NO BRASIL (1953-1964) 
(C) 2015 Editora Unesp

\section{Cultura Acadêmica}

Praça da Sé, 108

01001-900 - São Paulo - SP

Tel.: (0xx11) 3242-7171

Fax: (0xx11) 3242-7172

www.editoraunesp.com.br

www.livrariaunesp.com.br

feu@editora.unesp.br

CIP - BRASIL. CATALOGAÇÃO NA PUBLICAÇÃO

SINDICATO NACIONAL DOS EDITORES DE LIVROS, RJ

$\mathrm{S} 23 \mathrm{a}$

Santomauro, Fernando

A atuação política da Agência de Informação dos Estados Unidos no Brasil (1953-1964) / Fernando Santomauro. São Paulo: Cultura Acadêmica, 2015.

Recurso digital

Formato: ePub

Requisitos do sistema: Adobe Digital Editions

Modo de acesso: World Wide Web

Inclui bibliografia

ISBN 978-85-7983-705-0 (recurso eletrônico)

1. Brasil - Condições econômicas. 2. Desenvolvimento econômico Brasil. 3. Política externa - Brasil. 4. Relações internacionais. 5. Política externa - Estados Unidos. 6. Livros eletrônicos. I. Título.

$15-28924$

CDD: 327

CDU: $327^{\prime} 1953 / 64^{\prime}$

Este livro é publicado pelo Programa de Publicações Digitais da Pró-Reitoria de Pós-Graduação da Universidade Estadual Paulista "Júlio de Mesquita Filho" (UNESP)

Editora afiliada:

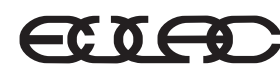

Asociación de Editoriales Universitarias de America Latina y el Caribe

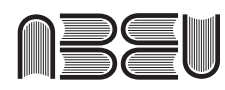

Associação Brasileira de Editoras Universitárias 
A Janayna, que saiu dos meus melhores sonhos para fazer da minha vida uma manhã de domingo 


\section{Agradecimentos}

Agradeço as orientações preciosas e suporte constante do professor Clodoaldo Bueno que, sempre com calma e sabedoria, me guiou nos passos da pesquisa histórica em Relações Internacionais - que resultaram em minha tese de doutorado, base para esse livro. Ao meu supervisor durante a pesquisa nos Estados Unidos, James Woodard, um agradecimento especial pela orientação precisa para a consulta aos arquivos americanos, pelo apoio e amizade. Obrigado ao prefeito de Guarulhos, Sebastião Almeida, pelo apoio, aprendizado e amizade.

Obrigado a Marianne Craven, Caryn Danz, Dana Shaw e Kathy Brion, por me ajudarem a encontrar os ex-funcionários da USIA no Brasil aqui entrevistados: Donald E. Mathes e Carl Dean Howard, a quem agradeço pela gentileza, disponibilidade e atenção dispensada. A Trina Hodges, obrigado por D.C. Agradeço ao mano Emanuel Brito, e a Roseanah França, pelas revisões amorosas. Obrigado a Jéssica e Celso, pelo tratamento das fotos e pelo Vicente. A Capes/ Fulbright, pela bolsa de doutorado "sanduíche" oferecida (20132014), que possibilitou a pesquisa nos arquivos norte-americanos. Muito obrigado aos professores do Programa San Tiago Dantas, especialmente a Tullo Vigevani e Samuel Soares. Agradeço igualmente a Elio Gaspari, pela atenção e sugestões preciosas. 
Meu muitíssimo obrigado aos amigos queridos e suas famílias, minhas fontes de alegria e força para continuar: Alberto, Ana Luiza, Borny, Brunos (Benatti e Langeani), Cler, Felipinho, Gabrielas (Bitencourt e Cano), Jean, João Roberto, José Maurício, Laio, Leo, Marcelo, Marco Antônio, Paula, Renata, Ricardos (Cruz, Drummond, Neves e Posada), Rodrigo e Nardini.

Agradeço eternamente a meus avós, tios, padrinhos, primos, sobrinhos, sogros e cunhados. A meus irmãos Renato, arquiteto do meu eu; e Beatriz, minha "irmãezinha". Obrigado a meu pai Edgar, primeiro doutor da família: meu amigo, exemplo e fortaleza. A minha mãe Silvia, a quem devo o amor pelo que "é histórico" e tantas outras coisas boas da vida. Minha mais importante professora, obrigado por sempre.

A Clara, obrigado pelo amor incondicional. Muito obrigado ao amor da minha vida, Janayna Gonçalves Rodrigues, por ser meu lar e oásis onde estivermos e pelo que somos, a melhor coisa do mundo. 


\section{SUMÁRIO}

Prefácio, por Clodoaldo Bueno 11

Prólogo: o golpe e o filme sobre o golpe 17

1 A formação da política de informação americana no exterior 29

2 A USIA no Brasil de 1953 a 1964179

3 O ocaso da USIA 309

Referências bibliográficas 319 


\section{Prefácio}

Mesmo razoavelmente bem estudado, o papel que os Estados Unidos desempenharam na crise interna do Brasil, nos idos de março-abril de 1964 e no período imediatamente posterior, ainda desperta o interesse dos analistas das relações internacionais, mercê, nomeadamente, da liberação de documentos guardados em arquivos oficiais norte-americanos. Fernando Santomauro, apesar e por causa disso, conseguiu elaborar com cuidado, profusão de detalhes e originalidade, um texto situado a cavaleiro da História e da Ciência Política, tendo por base sua tese de doutorado, agora liberada dos aspectos estritamente acadêmicos e enriquecido com novas achegas. Redigido em linguagem clara e escorreita, destina-se não somente ao leitor especializado, mas também a todos os que se interessam pela história nacional, de modo especial o referente ao caráter e significado do acompanhamento levado a efeito pela Casa Branca e o Departamento de Estado do que se passava no Brasil, visto em Washington como o país chave da América do Sul. O esforço de Santomauro resultou em trabalho embasado, em sua maior parte, em sólida documentação gerada pelas autoridades daquele país, a partir da qual ele demonstra a estrutura e funcionamento da USIA (United States Information Agency), criada em 1953 por Eisenhower. O esforço desta, não mensurável, pode ser considerado bem sucedido em 
suas atividades de propaganda no âmbito da Guerra Fria. A agência foi um instrumento a mais da política externa dos Estados Unidos e trabalhou em consonância com outros atores e componentes do seu soft power, cujas ações eram facilitadas pelo fascínio que despertava em outros povos o american way of life.

Ao fazer o histórico da USIA, Santomauro analisa e esclarece que os EUA desenvolviam atividades dessa natureza desde a Primeira Guerra Mundial, da qual foram partícipes no teatro de operações a partir de 1917, para em seguida demonstrar a estrutura e teia organizacional da agência no Brasil, os resultados da sua ação no período de 1953 a 1964, bem como seus meios e modos utilizados para acompanhar e ao mesmo tempo influenciar a opinião pública brasileira. Ao enfatizar o relativo ao advento do regime militar, contextualizando-o na visão dos norte-americanos então preocupados com o quadro mundial de tensão entre os dois pólos de poder, fica explicitada a disposição do Presidente Lyndon Johnson de ir até onde fosse necessário com vistas a impedir o surgimento de uma "nova Cuba" no continente. A Casa Branca acompanhou minuciosamente o desenrolar dos acontecimentos, mas descartando, já no início do levante militar, o desembarque de forças e apoio aberto aos revolucionários na avaliação de que se reverteriam em fortalecimento de João Goulart. Para os norte-americanos e atores brasileiros, como Juscelino Kubitschek, Goulart estava entregando o país aos comunistas. As notícias que foram apresentadas no Brasil e nos principais cinemas do continente, logo após o desfecho do movimento de 1964, foram produzidas pela USIA. Esses documentários só foram encontrados cinqüenta anos após os eventos no National Archives Administration (NARA) norte-americano.

A partir da década de 1970 a USIA perdeu relevância junto à Casa Branca. A partir de então suas ações passaram a ser direcionadas para as lideranças políticas, as do mundo cultural, da mídia e das universidades, realçando, mormente, acadêmicos de tendências próprias da social-democracia. O caráter da agência estava distante daquele da década de 1960; seguiu um novo compasso, adaptado ao fim da bipolaridade e ao fim do risco pelo qual passara o Brasil.. 
A atenção norte-americana voltava-se para outras áreas do planeta. Clinton encerrou as atividades da USIA em 1999. A fim de se evitar simplificações, é oportuno registrar a observação de Santomauro de que os presidentes democratas e republicanos agiram da mesma forma em relação às atividades e funcionamento da agência. $O$ autor nos lembra, em momento apropriado, que ela não foi a única do mundo a ter sucesso; os soviéticos dispunham, também, de eficiente aparelho para a mesma finalidade, focado, notadamente, na denúncia do que eles consideravam os males do capitalismo. Os órgãos de propaganda travaram verdadeira batalha ideológica em nível mundial.

Cabe finalmente realçar o equilíbrio do jovem autor ao elaborar sua narrativa, alicerçada também em arquivos brasileiros e em entrevistas com ex-diretores da USIA. Rica bibliografia e ilustrações completam as qualidades de uma obra relevante, cuja leitura torna-se necessária para os interessados em ampliar a composição do quadro das relações Brasil-Estados Unidos na segunda metade do século XX, justamente no período de enrijecimento da bipolaridade do poder mundial. 
[out of a]decent respect to the opinions of mankind,... [we urge that] facts be submitted to a candid world,... [and appeal to the Supreme Judge of ] the world for the rectitude of our intentions

Declaração da Independência dos Estados Unidos, 04 jul. 1776 (Documento 37)

Public sentiment is everything.

With public sentiment on its side, everything succeds; with public sentiment against it, nothing succeeds

Abraham Lincoln, em debate com Stephen Douglas, em 21 ago. $1858^{2}$

A man can be forced to carry a gun, but until he accepts an idea, his masters cannot be sure that he will use it in the direction they wish

Dwight D. Eisenhower, discurso de abertura da "Crusade for Freedom", 11 nov. $1952^{3}$

1 Documento 37.

2 Idem.

3 Documento 39. 


\section{Prólogo: o golpe e o FILME SOBRE O GOLPE}

Na noite de 30 de março de 1964, dois dias antes do "April Fool's Day" nos Estados Unidos, o $1^{\circ}$ de abril, popularmente conhecido como o "Dia da Mentira" no Brasil, o Presidente Lyndon Johnson atendeu, no Texas, um telefonema. Ele conversava com seu Secretário de Estado, Dean Rusk, que estava acompanhado de sua equipe e de representantes da CIA em Washington D.C. para definirem as ações a serem adotadas pelos Estados Unidos diante da crise política que dividia o Brasil entre os pró e os antipresidente João Goulart. ${ }^{1}$

Rusk alertou o Presidente americano que naqueles próximos dias, ou mesmo naquela noite, a situação brasileira poderia se agravar com uma reviravolta dos que, segundo ele, "resistiam" a Jango, isto é, parte das Forças Armadas e alguns governadores, principalmente dos Estados mais populosos do Leste, como Minas Gerais e São Paulo.

O secretário de Estado avisou o Presidente Johnson que, por precaução, já havia solicitado ao secretário de Defesa Robert McNamara, o envio de cargueiros com munição e armas não registradas. Segundo Rusk, "os representantes da CIA sugerem que essa força-tarefa inclua um LSD carregado com barcaças contendo

1 Documento 1. 
armamento apropriado e munições, no caso do suprimento de armas semiclandestinas ser aceito. O Secretário McNamara foi consultado para decidir sobre isso". ${ }^{2} \mathrm{Na}$ denominação da marinha americana, um LSD é um "Landing Ship, Dock", 3 navio de desembarque de doca, um cargueiro com capacidade para carregar armamentos, helicópteros e veículos anfíbios.

Além disso, Rusk já descrevia a Johnson os planos de ação militar, e se essa fosse necessária, descartava o uso dos marines americanos. Segundo a carta que o Secretário enviaria ao embaixador Gordon, lida a Johnson por telefone: "Obviamente, em um país com mais de 75 milhões de pessoas, maior que os Estados Unidos continental, esse não é um trabalho para um punhado de marines dos Estados Unidos". ${ }^{4}$

Ao mesmo tempo, o Secretário de Estado defendia o auxílio aos revoltosos com o envio de equipamentos militares que poderiam chegar mais rápido em aviões, pousando no Recife ou outro local do nordeste brasileiro. Rusk pedia a aprovação do Presidente para enviar a carta ao Embaixador no Brasil, Lincoln Gordon. Nela, pedia ao Embaixador que mobilizasse os adidos militares no País para definir as demandas de armamentos mais adequados à situação.

Na conversa, o secretário Rusk salientava que a decisão do Presidente deveria levar em conta, principalmente, a avaliação do embaixador Lincoln Gordon, que estava acompanhando as ações in loco. A carta a Gordon, aprovada pelo Presidente após a leitura pelo telefone, determinava que, a todo custo, os Estados Unidos deveriam evitar a tomada do Brasil por uma ditadura comunista - o que os governos de Jango e Leonel Brizola representavam claramente naquele momento, tanto para o Departamento de Estado, quanto para a CIA e Lyndon Johnson.

Na tarde do dia seguinte, 31 de março, o Presidente Johnson voltou a falar sobre o assunto com o sub-secretário de Estado, George

2 Documento 2.

3 Disponível em <http://www.navy.mil/navydata/fact_display. asp? cid=4200\&tid=1000\&ct=4>. Acesso em: $25 \mathrm{dez} .13$.

4 Transcrição da carta lida disponível em Documento 3. 
Ball, e com o assessor para assuntos inter-americanos, Thomas C. Mann, para saber da situação política brasileira e dos preparativos americanos. ${ }^{5}$ Com base nas reuniões entre o Departamento de Defesa e Embaixada no Brasil, ${ }^{6}$ foram confirmadas as intenções de envio de armamentos por navios, o que poderia levar até dez dias. Se fosse necessário uma ajuda mais rápida, poderiam ser acionados os navios que já estavam em Aruba e, dependendo da situação, como já havia sido proposto, aviões.

O subsecretário Ball atualizou o Presidente sobre as movimentações dos principais governadores e exércitos em nove Estados brasileiros, entre eles Minas Gerais, Rio de Janeiro e possivelmente São Paulo (segundo Ball, esse era chave para a definição da situação). Além disso, acompanhavam a movimentação política orquestrada no Congresso para o impeachment de Jango. Ball só esperava a definição de São Paulo para que a conjuntura se confirmasse nas próximas 12 horas e os Estados Unidos pudessem tomar uma posição oficial.

Desde janeiro de 1964, o Presidente Johnson também enfrentava no Panamá outra crise política na região, considerada por ele uma ameaça comunista. ${ }^{7}$ No auge da crise panamenha, em março de 1964, Johnson deixava claro que não permitiria nenhuma nova Cuba no continente, em conversa com o Senador Richard Russel:

Eu só disse que nós não vamos ter nenhuma Cuba por lá. Eles dizem que os comunistas têm uma base de apoio lá, que vão fazer o inferno e tentar dar um golpe comunista [...] [Eu disse] que nós não vamos ter outra Cuba no hemisfério, mesmo se eles tivessem homens suficiente, se ele não tivesse; eu mandaria mais do que ele. ${ }^{8}$

5 Documento 4. Algumas das gravações telefônicas desse dia também aparecem nos documentários brasileiros "O Dia que Durou 21 Anos", dirigido por Camilo Galli Tavares, e "Dossiê Jango", de Paulo Henrique Fontenelle, ambos de 2013.

6 Documento 5.

7 Mais sobre as instruções de Johnson para a crise no Panamá, em março de 1964, em Documento 6.

8 Documento 6. 
No Panamá, os Estados Unidos tinham respondido, desde janeiro, com uma intervenção militar com soldados americanos, que acabaram, entre outras coisas, matando 22 pessoas, após uma manifestação de estudantes. Os jovens queriam colocar a bandeira pananamenha na zona do canal, construído e cedido aos Estados Unidos até então. Até final de março, Johnson não se mostrava disposto a ceder ao governo panamenho, que por conta do incidente de janeiro, tinha rompido relações diplomáticas com os Estados Unidos, e queria rever a cessão do canal. Apesar da resistência inicial, as negociações entre EUA e Panamá avançaram a partir de abril de 1964.

Nos mesmos dias de março e durante os mesmos telefonemas com o Departamento de Estado, Johnson tinha que enfrentar o que acreditava ser duas crises comunistas no "hemisfério": no Panamá e no Brasil. E para as duas, ele acreditava que os EUA tinham que garantir o mesmo resultado, a todo custo, isto é, que não houvesse uma "nova Cuba" na região.

Diretamente do Texas, em 31 de março, na última recomendação ao Departamento de Estado antes do golpe militar, Johnson foi claro sobre o que fazer em relação ao Brasil: "Eu acho que nós devemos fazer tudo a nosso alcance e estarmos preparados para fazer tudo o que precisarmos, assim como estávamos no Panamá, se isso tudo for factível". 9

$\mathrm{Na}$ tarde do dia $1^{\circ}$ de abril, após as movimentações militares previstas no dia anterior e com o golpe em marcha, o Secretário de Estado e seus assessores ${ }^{10}$ fizeram uma teleconferência ${ }^{11}$ com o embaixador Gordon para saber dos acontecimentos das últimas horas e construir o cenário de ações a serem adotadas a partir de então.

Além de perguntarem sobre os desdobramentos políticos e deslocamentos militares (inclusive sobre a resistência de Brizola no Sul), o Departamento de Estado pediu orientações a Gordon para, se preciso fosse, desenvolver alguma atividade, oficial ou não, e reforçar a

9 Documento 9.

10 Pelo Departamento de Estado estavam Ball, Adams e Burton, Documento 7.

11 Documento 8. 
onda anti-Goulart: "Será que a adesão ao movimento anti-Goulart continuará sem algum encorajamento, velado ou explícito, vindo do nosso lado? [...] Algum dos líderes da revolução pediu a você algum apoio explícito? Algum sinal público de nosso apoio ajudará Goulart nesse momento?". ${ }^{12}$ Outra interessante informação da teleconferência do dia $1^{\circ}$ era a preocupação do Departamento de Estado sobre a situação e a posição de Juscelino Kubitschek, e se esse já havia sido contactado por Lincoln Gordon naquelas últimas horas.

Em sua resposta, Gordon disse serem preocupantes a ocupação das rádios gaúchas pelas forças comandadas por Brizola, a movimentação do $3^{\circ}$ exército no Sul e a greve geral convocada pelo Comando Geral dos Trabalhadores (CGT). Na mesma fala, o Embaixador mencionou a possibilidade de deslocar três destroieres e um submarino para a Baía de Guanabara, ${ }^{13}$ bem como a dificuldade de combustível para a locomoção desse submarino.

Segundo Gordon, um dos únicos a pedir apoio aberto dos americanos, além de possibilidade de auxílio de armas e força naval, foi Adhemar de Barros e seu grupo político, localizado em São Paulo, o que não foi levado em consideração pelo Embaixador Americano. Para Gordon, o apoio aberto dos americanos iria fortalecer Jango:

Com exceção de Adhemar e alguns de seus aliados Paulistas que continuam a falar não claramente sobre necessidades de armas e possível vontade de mostrar força naval ali, não houve nenhuma pressão por apoio declarado. Eu não considero que a abordagem Paulista seja séria ou responsável. Nesse momento, sinais abertos de nosso apoio seriam um erro político que jogaria a favor de Goulart. Nós devemos, é claro, continuar a estudar essa questão de hora em hora, na medida em que a situação evolua. ${ }^{14}$

12 Documento 8.

13 Documento 8.

14 Documento 8. 
Finalmente Gordon contava ao Departamento de Estado sobre o seu encontro com Kubitschek no dia 31 de março de 1964 e as impressões políticas dele em relação ao golpe. Segundo o documento, JK teria feito uma análise da política nacional, dito ao representante americano o que achava de Jango (associando-o ao comunismo), declarando sua ruptura com o seu ex-vice-Presidente e acreditando no sucesso de sua derrota. Segundo comentou Gordon ao Departamento de Estado, em $1^{\circ}$ de abril de 1964:

Eu encontrei Kubitschek às 21:15 e mandei uma mensagem que aparentemente não foi enviada no meio da confusão de ontem à noite. [...] Kubitschek disse que a movimentação de São Paulo seria crítica para o sucesso e se a rebelião fosse branda, Goulart abriria seu caminho para a ditadura. [...] Nós discutimos sobre o problema da legitimidade, que ele pensou que seria facilmente cuidado pelo Congresso, se o aspecto militar fosse resolvido. Ele tinha visto Goulart no meio da tarde e suplicou a ele que salvasse seu mandato fazendo uma ruptura clara com a CGT e os comunistas, mas Goulart disse que isso seria sinal de uma fraqueza que ele não poderia mostrar. [...] A hora teria claramente chegado e nessas horas não seria necessário nenhum apoio especial dos EUA. Acabei de saber que o relatório da conversa com Kubitschek foi enviado ontem como Embtel 2134. ${ }^{15}$

Outro relato de Kubitschek ao governo americano é registrado em um telegrama do dia 31 de março, em sua conversa com James Minotto, assessor americano para as relações com o Senado. Segundo o telegrama, JK confiava que o Golpe em marcha seria vitorioso, que as greves durariam até que "a fome começasse" e garantiu ao interlocutor americano ter rompido com Goulart, pois ele entregaria o País aos comunistas:

Em uma conversa com James Minotto, membro da equipe para o comitê de apropriações no Senado, Kubitschek disse que "para

15 Documento 8. 
razões práticas a situação já estava acabada. Aconteceria um golpe bem sucedido contra Goulart, e que a resistência a isso se resumiria a uma greve geral de dois ou três dias. Os trabalhadores, no entanto, iriam voltar ao trabalho assim que começassem a ficar com fome". Kubitschek também relatou que contou a Goulart que "ele estava rompendo com ele já que o Presidente estava seguindo um caminho que acabaria por entregar o país aos comunistas". ${ }^{16}$

Pouco mais de 45 dias depois do Golpe, os cinemas do Brasil e da América Latina, começaram a exibir um documentário de notícias, que aparecia antes dos principais filmes americanos em cartaz, nas melhores e mais movimentadas salas comerciais do continente. Apesar de aparentar ser uma produção brasileira, de caráter jornalístico, o filme era feito pela agência de informação norte-americana, a United States Information Agency (USIA).

Seu roteiro, encontrado depois de 50 anos nos National Archives norte-americanos em College Park (Maryland), era um dos diversos produzidos pela agência para o público brasileiro no período e esse, particularmente, foi o primeiro filme confeccionado pela USIA para narrar o que teria sido uma revolução democrática no Brasil.

O filme Victory for democracy ${ }^{17}$ contava como o povo brasileiro teria feito uma revolução popular em nome da democracia, salvando o país de uma ditadura comunista iminente. Segundo o documentário, em sua introdução, chegara ao fim "uma era de incerteza e medo. Por quatro anos, [o povo] sofreu com uma espiral inflacionária, alarmantes greves de trabalhadores, e promessas vagas e não cumpridas. Agora a nação parece tomar uma nova direção... e uma nova esperança". ${ }^{18}$

A seguir, o filme mostrava cenas de militantes "comunistas" sendo trazidos em um bonde, para servirem de "claque"19 oficial dos discursos comunistas do Presidente no dia 13 de março (discurso da

16 Documento 9.

17 O roteiro do filme está disponível em Documento 10.

18 Documento 10.

19 Documento 10. 
Central do Brasil), onde teria sido usada a velha tática comunista de confundir a população com discurso nacionalista e reformista, mas que no fundo seria de "tumulto e destruição". ${ }^{20} \mathrm{Na}$ continuação, citava as revoltas na Marinha brasileira, que segundo o filme da USIA teriam sido apoiadas por Jango, uma "clássica estratégia comunista de dividir para conquistar":

Marinheiros mais à esquerda e ligados à Associação da Marinha se trancaram no prédio da União Metalúrgica. Eles denunciavam a falta de comando, mas tinham o apoio do Presidente Goulart. Um encontro de almirantes no Clube Naval concluiu que esse era um esforço para dividir as forças armadas em diferentes campos... outro velho truque comunista. ${ }^{21}$

A partir daí, o documentário narrava a reação do Exército, apoiado pela população, registrada pelos jornais e a consequente vitória de seis Estados "resistentes" ao regime de Jango, liderados por Minas Gerais, Rio de Janeiro e São Paulo. Segundo o filme da USIA, em São Paulo, onde houve uma maciça comoção da população anti-Jango, não foi sequer necessária nenhuma ação militar durante os dias da "Revolução". ${ }^{22}$

O newsreel mostrava uma "revolução pacífica, rápida e feliz". ${ }^{23}$ Como saldo da "Revolução", o filme produzido pela USIA mostrava que alguns centros de subversão foram fechados e quartéis reconhecidamente comunistas foram averiguados pelo Exército. No Rio de Janeiro, foram presos espiões comunistas chineses que teriam tramado matar algumas lideranças democráticas. ${ }^{24}$

20 Documento 10

21 Documento 10.

22 Documento 10.

23 Documento 10.

24 Documento 10. O caso dos nove chineses acusados de espionagem em 1964 é tratado profundamente em Guedes e Fiuza (2014). A Comissão da Verdade, iniciativa do governo brasileiro finalizada em 2014, inocentou os nove chineses, que teriam sido acusados e condenados injustamente após o Golpe. 
Como conclusão, o documentário mostrava a chuva de papel picado e serpentinas durante a "Marcha da Família, com Deus e pela Liberdade", narrada como uma "manifestação da vitória, outra demonstração espontânea do apoio popular à mudança, e uma volta ao curso natural da Nação". ${ }^{25}$

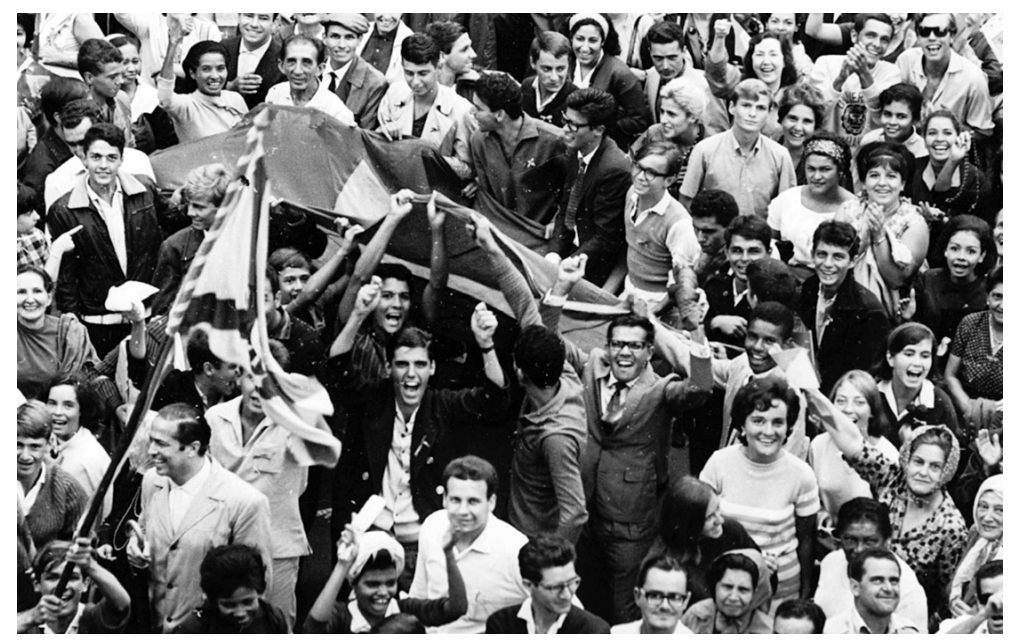

Figura 1 - População na comemoração da Marcha da Família, com Deus, pela Liberdade, em 02/04/64. Foto tirada e distribuída pelo USIS no Rio de Janeiro.

Por fim, a bandeira brasileira aparecia ao fundo e a narração anunciava que ainda havia muito a ser feito depois da eleição de Castelo Branco pelo Congresso, para cumprir o mandato restante e liderar a nação nos desafios que se impunham a seguir. O filme terminava em tom triunfante: "O povo está determinado que esse deve ser um grande ponto de mutação na sua história”. ${ }^{26}$

Como se percebe, as ações imediatas da USIA em total coordenação com as orientações da Casa Branca, demonstram perfeitamente o papel que a agência exerceu entre as ações da Política Externa

25 Documento 10. Todas as imagens do livro estão disponíveis, em seu formato original, em: <http://usianobrasil.blogspot.com.br>.

26 Documento 10. 
Americana no Brasil, confundindo a opinião pública nacional por meio de ações midiáticas não-assinadas e passando aos espectadores brasileiros a visão conveniente ao governo estadunidense.

Portanto para melhor compreender as relações Brasil-Estados Unidos, não é possível deixar de considerar a influência norte-americana nos modos de viver e de pensar do brasileiro, o que acaba por se refletir também nas relações políticas e econômicas entre os dois países. A história mostra que essa influência não aconteceu por acaso. Durante grande parte do século XX, o governo norte-americano se preparou com uma grande estrutura para atingir de forma eficiente a opinião pública brasileira.

A presente obra procura demonstrar como o governo norte-americano agiu, por meio da USIA, baseando-se em pesquisas quantitativas e qualitativas, bem como usando o entretenimento, a propaganda e a comunicação para influenciar grande parte dos brasileiros de acordo com os seus interesses políticos e econômicos.

Criada em 1953 pelo Presidente Eisenhower, a USIA foi a agência americana de maior presença no exterior, com postos em mais de 300 cidades ao redor do mundo, entre os anos 1950 e 1960. Durante o período mais acirrado da Guerra Fria dificilmente alguma atividade do governo americano no exterior deixava de se relacionar direta ou indiretamente com alguma ação da USIA.

Entretanto as diversas ações estratégicas da USIA não foram resultado só da oposição entre EUA e URSS no pós-guerra. A USIA foi fruto de um longo processo que se confunde com a história da política externa norte-americana no século XX, relacionando-se diretamente com sua postura em relação ao mundo, com seus avanços e retrocessos, e com a sofisticação do uso de diversos instrumentos de política externa ao mesmo tempo (cultura, informação, cooperação, comércio e política).

Para tentar explicar esse processo, no capítulo 2 são analisados os antecedentes da USIA ao longo da primeira metade do século XX. A análise parte desde os esforços de propaganda americana da $1^{\mathrm{a}}$ Guerra, seus métodos e criação de uma política americana de "informação" no exterior, chegando às ações tomadas durante a 2a Guerra, 
inclusive no Brasil. Além disso, observa-se como essas estruturas criadas e abandonadas foram reinventadas e potencializadas no pós$-2^{\text {a }}$ Guerra, naquele momento com novo foco na batalha ideológica entre os blocos capitalista e comunista.

O capítulo 3 procura demonstrar a formação, os objetivos, as ações e os resultados alcançados pela USIA no Brasil (ponto focal das políticas de informação americana na América Latina), desde sua criação, em 1953, até o golpe civil-militar de 1964 (ano em que Edward Murrow renuncia ao cargo de diretor da USIA).

Durante esse período, a agência era responsável por acompanhar e influenciar a opinião pública brasileira por meio de vários canais: uma agência de notícias própria (com publicações em jornais e revistas), produção de programas de rádio e TV, constantes pesquisas de opinião pública, além de alianças estratégicas com políticos, jornalistas, associações civis, bem como entre cidades americanas e brasileiras.

Essas ações atingiam direta ou indiretamente, desde donas de casa até agricultores, sindicatos, igrejas, estudantes e lideranças políticas (muitas vezes em conjunto com Departamento de Estado, CIA, USAID, Consulados e ONGs), misturando pesquisa de mercado, propaganda pró-EUA, contrainformação, comunicação de massa, turnês artísticas e bibliotecas públicas. Tudo isso sendo feito em harmonia com os interesses econômicos norte-americanos.

A USIA possuía, como coordenadores locais, agentes de relações públicas que trabalhavam nos postos da agência, os USIS (United States Information Services). Geralmente o agente de relações públicas chefiava uma equipe com pelo menos um agente de informação e um agente de relações culturais, que disseminavam as mensagens americanas ao público brasileiro de acordo com as instruções de Washington, mesclando propaganda e entretenimento.

$\mathrm{Na}$ maioria das vezes, os USIS eram baseados nos consulados americanos das principais cidades brasileiras (como São Paulo, Rio de Janeiro, Belo Horizonte, Belém, Salvador, Recife, Curitiba e Porto Alegre), e com postos móveis para cidades no interior do Brasil. Os postos locais da USIA criaram e gerenciaram bibliotecas públicas e centros-binacionais Brasil-Estados Unidos, onde era oferecido o 
ensino de inglês e de onde eram irradiadas as informações para os públicos locais. Nos anos 1960, o Brasil contou com o maior número de centros binacionais no mundo, com 64 deles espalhados pelo País.

Além disso, a agência era responsável pela pesquisa periódica de mídia e da opinião pública brasileira, que avaliava a imagem dos Estados Unidos, de seus Presidentes e de suas ações internacionais nos principais meios de comunicação brasileiros. As pesquisas também cobriam a situação de temas como reforma agrária, eleições locais e, principalmente, a reação de diferentes grupos brasileiros em momentos de crise política nacional ou internacional (como na renúncia de Jânio e nas crise dos mísseis). Tais pesquisas se intensificaram nos primeiros anos da década de 1960, sempre medindo a popularidade de líderes tidos como subversivos, como Jango, Brizola, Julião, Che Guevara e Fidel Castro. Em seguida, os relatórios de opinião pública no Brasil eram enviados aos diversos órgãos do governo americano, inclusive ao Presidente da República, subsidiando importantes decisões norte-americanas no País durante o período.

Já o tema do capítulo 4 é a forma como a USIA se adequou às novas realidades impostas a partir do governo Lyndon Johnson, perdendo sucessivamente orçamento e importância no interior do governo americano durante a segunda metade dos anos 1960 e 1970, até o seu ocaso nos anos 1980 e 1990, com fim em 1999.

A obra foi baseada essencialmente na consulta direta aos arquivos norte-americanos em Washington D.C. (National Archives and Records Administration/NARA), Maryland (NARA, College Park), Nova York (NARA/Manhattan, Public Library, Rockefeller Archives Center/RAC); e brasileiros, no Rio de Janeiro (Biblioteca Nacional e Arquivo Nacional). Além disso foram usados como referência os livros e estudos de ex-funcionários da USIA, bem como realizadas entrevistas com ex-diretores da USIA no Brasil. 


\title{
1 \\ A FORMAÇÃO DA POLÍTICA DE INFORMAÇÃO AMERICANA NO EXTERIOR
}

\begin{abstract}
o imenso impacto cultural que se produziu como resultado dessa presença americana no Brasil não foi aleatório, mas obedeceu a um planejamento cuidadoso de penetração ideológica e conquista de mercado
\end{abstract}

Gerson Moura ${ }^{1}$

Enquanto as principais potências europeias desenvolviam políticas de educação, cultura e propaganda no exterior desde fins do século XIX, os Estados Unidos começaram a sistematizar sua política com certo atraso, a partir da $1^{\text {a }}$ Guerra, organizando uma política de "informação"2 no plano internacional, que seria o embrião de sua forma de agir durante todo século XX.

1 O historiador brasileiro Gerson Moura (1985, p.11) foi uma das principais referências para esta obra, principalmente por seu estudo sobre a presença ideológica americana no país durante a $2^{\mathrm{a}}$ Guerra.

2 Quando referida a política americana de informação anterior à $1^{a}$ Guerra decidi usar aspas em informação, por ser esse um conceito com seu significado próprio, definido pelos americanos apenas a partir de 1917, como veremos no ponto 2.1. Como uso para designar uma ação anterior a essa decisão, faz-se essa ressalva. 
França, Alemanha e Inglaterra, por exemplo, já se utilizavam de elementos de educação, cultura e propaganda como instrumentos de política internacional e como complementos importantes para consecução de seus interesses (políticos e econômicos) no exterior, inclusive no Brasil. ${ }^{3}$

A França, por exemplo, a partir do final do século XIX, utilizou-se da educação voltada para às elites brasileiras por meio das escolas religiosas (financiadas pela Terceira República), ${ }^{4}$ desde a base da educação, enquanto internamente fazia o contrário, com reformas educacionais em defesa da educação laica. ${ }^{5}$

Desde os anos 1920, a França elaborou uma estratégia centralizada em um órgão do Ministério das Relações Exteriores, chamado Service des Oeuvres Françaises à l'Étranger (SOFE), ${ }^{6}$ responsável pela disseminação da cultura e da educação francesa no exterior, e durante o entre-guerras se contrapunha principalmente à propaganda alemã.

A partir dos anos 1930 o Estado francês financiou a vinda de seus professores para a recém-formada Universidade de São Paulo. Esses professores - entre eles, ${ }^{7}$ Claude Lévi-Strauss - foram selecionados e vieram para o Brasil também como agentes políticos do governo francês, exercendo essa dupla função secretamente. ${ }^{8}$

3 O diplomata brasileiro Edgard Telles Ribeiro, em obra pioneira no Brasil (Diplomacia Cultural, 1989), analisou o uso da cultura como complemento importante para a política externa de diversas potências ocidentais, como a Alemanha, a Inglaterra, além de citar os casos de França, Estados Unidos e Brasil.

4 Que durou desde 1870 até 1940.

5 Santomauro (2012a, p.213). A Aliança Francesa, que também exerceu importante papel, foi fundada em 1883 e com apoio governamental se instalou nas principais cidades do mundo para a difusão do francês.

6 Fundamentais para entender a ação do SOFE no Brasil são os livros de Hugo Suppo (1998), Denis Rolland (2000) e Gilles Matthieu (2000).

7 Garric (Literatura francesa), Cornaert (História da Civilização), Deffontaines (Geografia), Arbousse-Bastide (Sociologia), Berveiller (Literatura Greco-Latina) e Borne (Filosofia e Psicologia) foram os primeiros a serem mandados pelo governo francês, para a USP, em 1934. Lévi-Strauss, assim como Monbeig, Hourcade e Maugüé vieram ao Brasil em 1935. Santomauro (2012a, p.223).

8 (Id., 2012b, p.219). A política cultural francesa no Brasil também foi tema de meu Mestrado, defendido no Departamento de História da PUC-SP, em 2007, sob orientação do professor Antonio Pedro Tota. Mais sobre a necessidade do 
Depois da segunda metade do século XIX, a presença americana no exterior começou a se dar de maneira mais espontânea, muitas vezes por meio de missionários religiosos que de certa forma abriam caminho para as frentes comerciais. Mas isso ainda era feito sem o apoio sistemático ${ }^{9}$ do governo americano, em contraposição ao que já fazia o governo francês com seus religiosos, no mesmo período. Os historiadores americanos Sellers, May e Mcmillen (1990, p.264) descrevem essas missões religiosas como o começo do fim do isolamento americano no exterior:

Uma missão divina constitui outro fator nas mudanças ocorridas na política externa: Protestantes evangélicos - em especial as seitas que possuíam missões no exterior - promoviam um imperialismo de retidão moral, isto é, que os norte-americanos liderariam não só pelo exemplo remoto mas pela presença física entre raças ainda não remidas do pecado. $\mathrm{O}$ expoente mais influente dessa doutrina foi o reverendo Josiah Strong, autor do sucesso de livraria "Our Country” (1855), que insistia em que os Estados Unidos, com seu "gênio anglo-saxão para a colonização", deviam espalhar as bênçãos do protestantismo e democracia, "na direção do México..., América Central e do Sul, para as ilhas do mar, para África e além”. E lembrava a seus leitores as implicações práticas da presença norte-americana no ultramar: o processo civilizatório cria "mais e mais nobres necessidades" e "o comércio segue o missionário".

Com a industrialização do país, a formação das grandes corporações americanas e das grandes fortunas, a filantropia americana cresceu na América Latina. Sem que se exclua o objetivo de expandir as classes médias no novo mundo e abrir mercado para a construção

caráter secreto dos professores franceses no exterior, François-Poncet (1922), MATTHIEU (2000, p.67).

9 Hixson (1997, p.1) no entanto, destaca que mesmo sem uma estrutura própria, a propaganda, com objetivo de moldar atitudes das "massas" no exterior já fazia parte das atividades do Estado Americano desde a declaração de independência do país. 
de estradas, carros, petróleo, eletricidade e produtos americanos. As associações filantrópicas americanas nasceram nesse contexto, como o Rotary Club (em 1905), a Carnegie Endowment (1910), ${ }^{10}$ a Fundação Rockefeller (1914), o Lions Club (1915) e Kiwanis (1917), e rapidamente se espalharam em mais de 190 países, por meio da ação de missionários, educadores, e com campanhas específicas, como a eliminação da pólio e da cegueira. ${ }^{11}$

A criação de uma política de "informação" no exterior, na América Hispânica e também no Brasil, portanto, nasce nesse contexto quando as potências europeias já tinham atividades sólidas, respaldadas pelo governo, e que fortaleciam as suas políticas externas.

Como será observado ao longo deste capítulo, por mais que os Estados Unidos tivessem inimigos ideológicos prioritários na América Latina, muito bem definidos durante a $1^{\mathrm{a}}$ e $2^{\mathrm{a}}$ Guerras e Guerra Fria é importante salientar que a presença ideológica europeia se manteve como motivo constante de preocupação americana. ${ }^{12}$

Um memorando ${ }^{13}$ do posto local da USIA no Uruguai (United States Information Service ${ }^{14}$ de Montevidéu), enviado à sede da USIA em Washington mostra que, mesmo em 1963, quando os EUA tinham o comunismo como principal alvo e já consideravam ganha a disputa ideológica com os franceses no Brasil, eles ainda

10 Mais sobre as ações das fundações norte-americanas no exterior em Pells (1997, p.14-15).

11 Arndt (2005, p.22). Arndt, uma referência entre os estudos da USIA, ex-funcionário da USIA e do Departamento de Estado, foi ex-professor das Universidades de Columbia, Virgínia e George Washington (mais informações sobre o autor disponível em <http://www.state.gov/p/io/unesco/members/49225. htm >. Acesso em: 15 jan. 2014.

12 Haines (1989, p.165-175) observa que no auge da batalha ideológica anticomunista nos anos 1950 e 1960, os Estados Unidos continuaram monitorando as ações de propaganda francesa na região, mesmo considerando ganha a disputa entre a nova geração de brasileiros.

13 Documento 12. Pode-se observar aqui também a proximidade entre o Instituto Gallup e USIA. Nos capítulos 2 e 3 esse assunto será aprofundado.

14 Os United States Information Services serão chamados de USIS ao longo desta obra. 
monitoravam fortemente as ações de propaganda dos países europeus no Brasil, Argentina e Uruguai.

Baseado em relato de Jorge Ferreira, um ex-agente exclusivo do USIS Montevidéu e então diretor do Instituto Gallup do Uruguai, o documento descrevia as pesquisas de opinião pública feitas sob encomenda dos serviços de propaganda francês e alemão. Nessas, estavam postas as preferências de rádio e imagem das populações da Argentina, Brasil e Uruguai como base para os programas de propaganda daqueles países. As informações eram repassadas pelo funcionário do Gallup aos Estados Unidos, que acompanhavam as ações alemãs e francesas de perto e, na ocasião, ainda se preocupavam com a forte presença econômica alemã na região. ${ }^{15}$

O que se percebe pela documentação e relatos de funcionários é que acima dos adversários ideológicos ${ }^{16}$ principais em diferentes momentos do século XX, os Estados Unidos buscavam ser a principal influência em toda América Latina, com fins econômicos e políticos. ${ }^{17}$

O historiador da CIA, Gerald Haines, em seu livro The americanization of Brazil, essencial para entender como os Estados Unidos montaram a estratégia de americanizar o Brasil para conseguir mais facilmente seus objetivos políticos e econômicos no pós-guerra, explicita que o interesse americano não era momentâneo, e sim uma vontade de afastar qualquer influência "externa" no Brasil: "Enquanto tentavam vencer a batalha psicológica com a União Soviética, os representantes americanos também procuravam substituir

15 Documento 12.

16 Aqui não será adotado nenhum conceito específico de ideologia, ou "ideológico”. O sentido será o mesmo adotado pelos próprios agentes, com a conotação mais ampla, de "conjunto de ideias.

17 Moura (1985, p.11), ao estudar a $2^{\text {a }}$ Guerra, também detecta o esforço mais profundo dos EUA: "esse processo de exportação cultural era parte integrante de uma estratégia mais ampla, que procurava assegurar no plano internacional o alinhamento do Brasil (e da América Latina) aos Estados Unidos, país que naquele momento procurava afirmar-se como uma grande potência e centro de um novo sistema de poder no plano internacional.". 
a tradicional influência europeia no Brasil pelos valores, estilos e padrões americanos". ${ }^{18}$

Ao longo deste capítulo será observado como essa política de informação americana se construiu ao longo do século XX. De maneira mais estruturada a partir da $1^{\text {a }}$ Guerra, essa se tornou mais marcante a partir do entre-guerras, atingindo seu auge durante as primeiras décadas da Guerra Fria.

\section{Wilson, o CPI e as bases da política de informação norte-americana}

Como o Secretário Baker ${ }^{19}$ destacou, a guerra não foi travada somente na França. Atrás das linhas de tiro, atrás dos exércitos e marinhas, atrás dos grandes armazéns de suprimentos, outra luta era travada com a mesma intensidade e com quase o mesmo significado, atrelada às vitórias e derrotas. Eram as lutas pelas mentes dos homens, pela "conquista das suas convicções", a frente de batalha dava-se em cada casa, em cada país. A Grande Guerra diferenciou-se, essencialmente, de todos os conflitos anteriores pelo reconhecimento da Opinião Pública como uma Força Armada Maior. ${ }^{20}$

George Creel ${ }^{21}$

18 Haines (1989, p.176). Haines também foi pesquisador do National Archives e no NSA (National Security Agency), nos anos 1980. Além de ser especialista sobre as ações da CIA, especialmente no Brasil, o historiador se tornou célebre por estudar as políticas americanas para os objetos não identificados. Sobre o autor, disponível em <http://www.colorado.edu/cwa/bios. html? id=130\&year=2001> Acesso em: 06 nov. 2014.

19 Newton D. Baker, Ministro da Guerra dos Estados Unidos de 1916 a 1921.

20 Creel (1920a, p.3), How we advertised America. A edição original tem uma curiosa epígrafe ao título, que explicita a missão, quase que religiosa, da cultura americana mundo afora: "The First Telling of the Amazing Story of the Committee on Public Information that Carried the Gospel of Americanism to Every Corner of the Globe".

21 Diretor do Commitee on Public Information. 
Apesar de haver uma crescente preocupação com a opinião pública nacional e estrangeira já nos primeiros anos do século $\mathrm{XX}^{22}$ os princípios fundamentais que estabeleceram a forma de "contar a história americana ao mundo" ${ }^{23}$ nasceram durante a $1{ }^{\text {a Guerra, durante }}$ o governo Wilson.

Foi a partir do recém-criado Committee on Public Information (CPI) que o termo "informação" foi cunhado para designar as ações de propaganda, difusoras da visão americana e do american way of life. Também nessa oportunidade, foram criados os postos locais de informação no exterior (United States Information Services/USIS) com uma estrutura que misturava relações públicas, cultura e informação. Finalmente, com o CPI foi formada uma relação direta entre o Presidente da República e as ações de informação.

O jornalista George Creel, que apoiou Wilson e trabalhou na campanha de sua reeleição em 1916, ${ }^{24}$ foi o escolhido pelo Presidente para comandar o CPI; seu cargo foi anunciado em abril de 1917, uma semana antes da entrada dos Estados Unidos na Guerra. O papel do CPI era definir a estratégia de propaganda e divulgar as ideias wilsonionas: tanto internamente, ${ }^{25}$ para convencer os americanos da importância de lutar na Guerra; quanto externamente, para justificar

22 Elder, (1968, p.34) comenta que as relações públicas ganharam cada vez mais importância na política externa norte-americana, principalmente a partir de 1913, quando secretários de Estado começam a explicar suas ações aos públicos interno e externo em coletivas de imprensa regulares.

23 "Telling the American Story to the World" era o lema da USIA, que aparecia abaixo do logo da agência, na entrada de sua sede, Pennsylvania Avenue, 1776, em Washington D.C. (Elder, ibidem, p.x).

24 Henderson (1969, p.24). Creel era também editor do jornal liberal (no sentido americano) Rocky Mountain News. Sobre a relação de Creel com Wilson antes, durante e após a $1^{\text {a }}$ Guerra, uma referência importante é o livro de Creel "The War, The World And Wilson” (Creel, 1920 b).

25 Sellers, May e Mcmillen (1990, p.303) criticam as ações do CPI. Para eles, eram manipuladoras da opinião pública americana, com campanhas que justificavam a participação americana na Guerra, por meio de mais de 75 milhões de panfletos e publicações como "Porque estamos lutando" e "O significado da América". 
a sua presença militar no exterior e levar o "americanismo" a cada canto da terra.

O CPI tinha uma plataforma de ação que articulava a diplomacia governamental, as políticas culturais e de propaganda, mobilizando diversos setores da sociedade americana. Durante a guerra, Wilson controlava pessoalmente as atividades do CPI, comitê chefiado por Creel e também formado pelos Secretários de Estado, de Guerra e da Marinha. Wilson chegou a afirmar: "Sou muito ciumento quando o assunto é propaganda, eu quero manter os casos de publicidade, totalmente, nas minhas próprias mãos". ${ }^{26}$

Foi por decisão de Creel que o termo "propaganda" foi rechaçado para denominar o nome da instituição recém-criada e sua forma de agir; para ele, essa palavra carregava a ideia de distorção da verdade. Como nome das ações de seu Departamento, Creel escolheu o termo "informação".

Segundo Creel, ${ }^{27}$ as principais potências europeias, que tinham seus órgãos oficiais de propaganda, ${ }^{28}$ usavam a mentira como forma de manipulação da opinião pública mundial, o que os mantinha na "escuridão e desilusão". Como resposta a isso e para fazer "amizade" com os países neutros até então, Creel propunha uma política de comunicação, que fosse "educativa e informativa".

O curioso é que ao mesmo tempo em que Creel nega o termo propaganda para denominar as ações do CPI, a sua própria editora, em How we advertised America, classificava o livro como "International Propaganda and Communications", em sua folha de rosto. Desde Creel e o CPI, as diversas agências americanas responsáveis pela propaganda americana no exterior adotaram o termo "informação", e nunca propaganda, como será demonstrado nos subcapítulos seguintes.

Para o esforço de guerra, Creel conseguiu formar uma estrutura governamental sem precedentes na história americana, convocando

$26 \operatorname{Arndt}(2005$, p.29).

27 Creel (1920a, p.4).

28 Para Creel (ibidem) a Alemanha "carregou" o termo propaganda com o sentido de despitar e desvirtuar. 
diversos talentos do jornalismo, publicitários, escritores, professores, cineastas e líderes sindicais para a produção de filmes, exposições, palestras, publicações, cartazes e pôsteres nos EUA e em mais de 650 escritórios de comércio dos EUA no mundo. ${ }^{29}$

No exterior, o CPI (por meio dos USIS) usava as embaixadas americanas para a publicação de anúncios e notícias sobre os EUA em jornais estrangeiros. A maioria dos USIS ficava nas capitais de países aliados e neutros, com atenção especial aos países da América do Sul e Central, onde se identificava forte presença alemã. ${ }^{30}$ É com o CPI que também começaram a se formar centros binacionais em países da América do Sul. ${ }^{31}$

Outra particularidade da política de informação dos EUA no exterior que se iniciou com Creel, foi a de juntar os órgãos responsáveis pela "informação" (propaganda e às vezes contrainformação) com os responsáveis pela cultura. A partir do CPI, a estrutura básica de um USIS no exterior, chefiada por um Public Affairs Officer (PAO) tinha como subordinados um Cultural Affairs Officer (CAO), cargo responsável pela cultura, que dirigia principalmente as atividades de longo prazo, em educação e arte, e ao seu lado um Information Officer (IO), responsável pela comunicação e informação imediatas. ${ }^{32}$

Para desenhar a estratégia do CPI na América do Sul, Creel (1920a, p.365) designou o jornalista e tenente F. E. Ackerman, cedido pela Marinha, e que fez uma viagem prospectiva ao continente sul-americano para estudar os materiais que seriam mais efetivos e definir os locais dos postos do CPI (USIS). Ele visitou, entre outras cidades e estados, Pernambuco, Rio de Janeiro, Santiago, Lima, Valparaíso e Buenos Aires.

29 Arndt também destaca a ação de Creel, ao misturar cultura e informação no mesmo "omelete", como o começo dessa forma de agir dos EUA a partir de então, Arndt (p.29 e 34): "Creel swirled the scholars and advertisers into one omelette, to win the war - and to serve the ends of US power".

30 Creel (1920a, p.365).

31 Arndt (Id., p.93).

32 Tanto Telles Ribeiro (1989, p.69) quanto Arndt (2005, p.xix) destacam essa singularidade americana no jeito de mesclar cultura e informação na sua estratégia de propaganda no exterior. 
Com auxílio direto dos consulados e embaixadas locais, o CPI promoveu aulas gratuitas de inglês, criou bibliotecas e salas de leitura para divulgar as publicações norte-americanas. Além disso, estimulou a exibição dos filmes mudos produzidos em Hollywood ${ }^{33}$ e a exibição radiofônica da programação de canais comerciais norte-americanos, transmitido por ondas curtas, emitidas por navios norte-americanos localizados na costa brasileira.

O CPI tinha um acordo com a Marinha que possibilitava a transmissão de discursos e programas traduzidos para cada país, nas principais capitais do mundo, nos USIS e centros binacionais (Henderson, 1969, p.26). Além disso, para lugares mais distantes, onde jornais pró-EUA não chegavam, ou não havia bibliotecas, panfletos eram lançados como bombas pelos aviões americanos. Em alguns casos, o CPI chegou a utilizar balões para torpedear os seus folhetos pelo ar (Hixson, 1997, p.1).

O próprio Creel (1920a, p.5) descreve a amplidão das atividades do CPI durante a $1^{\text {a }}$ Guerra:

Não houve nenhuma parte da grande máquina da guerra que nós não atingimos, nenhum meio de mobilização que não empregamos. A mídia impressa, a mídia falada, os filmes, o telégrafos, com cabos, sem cabos, os cartazes - tudo isso foi usado na nossa campanha para fazer que nossa população e todas as populações entendessem as causas que levaram à América a pegar em armas.

Para Argentina, Uruguai e Paraguai, um jornalista de Austin (Texas) chamado H.H. Sevier, foi nomeado diretor regional do CPI para a América do Sul. De seu escritório, em Buenos Aires, tinha a missão de fazer a voz americana chegar às cidades longínquas e vilarejos daqueles países. Em relatório de Sevier para Creel (1920a, p.368), o diretor regional observou que antes da presença do CPI na região a grande maioria das publicações sul-americanas não cobriam

33 Pells (1997, p.8) observa que o conteúdo dos programas e filmes do CPI sempre valorizava a prosperidade, a inovação, o progresso e a democracia americana. 
notícias sobre os EUA, pois as agências internacionais eram majoritariamente europeias.

No mesmo relato, Sevier descrevia a relevância da distribuição de notícias, fotos, pôsteres sobre os EUA, mas salientava, sobretudo, a importância da aproximação pessoal com a elite política da América do Sul. Para isso, entre outras atividades, ele palestrava constantemente em escolas e universidades locais.

Para o comando no Brasil, que tinha um diretor próprio (independente da América do Sul), foi designado o próprio embaixador dos EUA no país, Edwin V. Morgan (Creel, 1920a, p.248), que no geral seguiu as mesmas orientações e atividades do Committee na região. Relatos (ibidem, p.373) de Morgan ao CPI mostram que a implantação de duas agências de notícias americanas no país, fruto do esforço do CPI, ${ }^{34}$ facilitaram o trabalho de informação no país. A Associated Press e a United Press, segundo Morgan, tiveram um crescimento drástico de clientes a partir de então, e foram decisivas para construir a campanha permanente de entendimento e amizade para com os EUA.

Entre outras ações no Brasil, o CPI traduzia publicações próprias para o português, que explicavam os motivos da entrada dos Estados Unidos na guerra, como o panfleto de 36 páginas How the war came to America, ${ }^{35}$ que explicava a luta pelos princípios universais de democracia e liberdade que regiam o país, desde a guerra de independência americana até aquele momento.

O panfleto de 1918 acusava a Alemanha de lutar clandestinamente, por meio da manipulação da opinião pública nos países sul-americanos, apoiando formadores de opinião, e comprando ou subsidiando jornais. Em How the war came to America, os EUA explicavam para a população dos países sul-americanos que o motivo pelo qual entravam na guerra era para evitar a separação de

34 Segundo Ninkovic, (1981, p.13), em sua curta duração, o CPI sincronizava as atividades culturais com os esforços do setor privado.

35 Documento 13. O folheto teve tiragem de 5.428.048, sendo 9.375 em português. Outra publicação produzida pelo CPI, "German Plots and Intrigues", teve uma tiragem de 15.000 exemplares em português Creel (1920a, p.477-478). 
um continente americano unido pelos mesmos ideais universais de liberdade e democracia, consagrados pela Doutrina Monroe. ${ }^{36}$

Apesar do relativo sucesso das ações de propaganda do CPI tanto internamente quanto externamente, com o fim da guerra em novembro de 1918, o Congresso norte-americano começou a investigar e criticar pesadamente as ações do CPI, as quais não seriam condizentes com a democracia americana, principalmente em tempos de paz. Em março de 1919, o Congresso americano, (que ainda imporia derrotas maiores à política externa de Wilson no pós-guerra), paralisou as ações do CPI abruptamente (Elder, 1968, p.34) e algumas ações ainda em curso foram interrompidas.

Em junho de 1919, o CPI foi dissolvido formalmente pelo Congresso, que vetou o orçamento para todas as suas atividades. ${ }^{37} \mathrm{Nem} o$ relatório final sobre as atividades do CPI teve orçamento disponível para sua impressão. ${ }^{38} \mathrm{~A}$ partir daí, mesmo com a falta de uma política de governo para a informação americana no exterior, a demanda privada para a expansão cultural americana no exterior continuou. ${ }^{39}$ Durante os anos 1920 e 1930, os EUA continuaram se fazendo cada vez mais presentes, principalmente nos países europeus e

36 Documento 13, p.9.

37 Creel, (1920 a, p.427), criticou veementemente o fechamento do CPI e a falta de visão da medida repentina tomada pelo Congresso, deixando sem pagamento ações já contratadas e aluguéis sem pagamento.

38 Segundo Henderson (1969, p.28), o relatório final, assim como todos os documentos do CPI foram mandados, no mesmo momento, para os arquivos nacionais (National Archives). Segundo ele, "The first U.S. information program come to an inglorious end.". Para Arndt (2005, p.27), mesmo com final melancólico, o CPI foi modelo para futuros formuladores de políticas de propaganda no exterior, como Goebbels e Mussolini. Além disso, as atividades do CPI plantaram as sementes para os futuros mercados de publicidade e relações públicas nos EUA: "CPI's alumni would found two great American industries: advertising and public relations, both legitimized forms of lying".

39 A falta de política de propaganda, cultural, ou de informação do governo americano no exterior nos anos 1920 e 1930 é apontada por diversos autores, como Frankel (1965, p.25), Henderson (1969, p.29), Arndt (2005, p.40), Elder (1968, p.34), Ninkovic (1981, p.14), Tuch (1990, p.14) e Pells (1997, p.22). Todos eles também destacam a significativa presença cultural privada nas mesmas décadas. 
latino-americanos, fosse pelos grandes conglomerados de meios de comunicação de massa, como o rádio e o cinema, ou pelas fundações privadas americanas no exterior, com a disseminação de programas assistenciais e de cooperação técnica e educacional.

No entre-guerras, enquanto a indústria cinematográfica dos principais países europeus, até então de ponta, não tinha grande capacidade de investimento para produção e distribuição de seus filmes (principalmente pela crise econômica causada pela guerra), Hollywood viveu seu boom, atraindo grandes nomes da Europa, como Charles Chaplin, e ocupando e ampliando definitivamente o espaço para seu cinema em todo o mundo (Pells, 1997, p.15).

A indústria radiofônica norte-americana também se expandiu na América Latina e Europa, principalmente nos anos 1930. Mesmo sem apoio do governo, as empresas de rádio se expandiram no hemisfério americano: por iniciativas sem fins lucrativos, como a World Wide Broadcasting Foundation, que começou a transmissão do programa University of the Air, produzido pela rádio WRUL de Boston; por iniciativas com fins comerciais, como as redes latino-americanas de rádio formadas pela Columbia Broadcasting Corporation (CBS) e por sua concorrente, a National Broadcasting Corporation (NBC), cujos programas eram patrocinados por empresas americanas (Henderson, 1969, p.29).

Sem o apoio do governo e do Congresso, ${ }^{40}$ foram principalmente as fundações privadas norte-americanas que retomaram o intercâmbio e as políticas artística, cultural e educacional no exterior no entre-guerras. Se destacaram principalmente as fundações nova-iorquinas Carnegie Endowment, Guggenhein e Rockefeller.

A fundação Simon Guggenhein tinha no livre intercâmbio de ideias para moldar um "global kind of thinking" 41 a motivação para

40 Uma exceção a essa regra é destacada por Frankel (1965, p.25), que aponta a exportação de materiais científicos e livros feitas pelo Smithsonian Institution para o exterior, aprovados e estabelecidos pelo Congresso no entre-guerras.

41 Ninkovic (1981, p.15) vê a formação de um "global kind of thinking" o príncipio buscado pelas fundações no entre-guerras. Foi isso que teria motivado iniciativas como a de John D. Rockefeller Jr., que em nome da promoção de uma 
as bolsas de estudos a acadêmicos latino-americanos. A Carnegie Endowment financiava diversos projetos educacionais dentro e fora do país, como a expansão de bibliotecas americanas (Arndt, 2005, p.40) em parceria com a American Library Association (ALA) ${ }^{42}$ Esta tinha papel central na organização e na ampliação de bibliotecas americanas no exterior. Durante a $1{ }^{\mathrm{a}}$ Guerra ambas foram importantes centros de divulgação dos produtos do CPI.

Nos anos 1920, a ALA continuou propagando a língua inglesa, livros, jornais e revistas americanas, realizando o intercâmbio de estudantes, livros e o treinamento de funcionários nas principais cidades da América Latina, em locais onde era encontrada certa dificuldade de assimilação. ${ }^{43}$

A fundação Rockefeller, por sua vez, tinha um foco maior no financiamento das atividades culturais e filantrópicas no exterior, também com programas na área médica, saúde pública e cooperação artística e universitária. Esta financiou a ida de 303 acadêmicos europeus aos EUA durante o período, muitos deles vítimas dos regimes de inspiração nazifascista. Para esse feito, despendeu cerca de

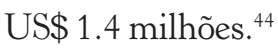

Mesmo sem a parceria com o governo, como aconteceu com o CPI durante a $1^{\text {a }}$ Guerra, as fundações privadas americanas continuaram sua missão, abrindo portas no mundo para os EUA por meio da educação, do ensino de inglês, das bolsas de estudos

irmandade cultural internacional financiou alojamentos estudantis internacionais nos EUA (Columbia, Chicago e Berkeley) e até a casa americana da Cité Universitaire de Paris, na década de 1920.

42 Além das fundações já citadas, Pells destaca o American Council of Learned Societies, e o Commonwealth Fund que também financiaram bolsas para atividades de acadêmicos americanos no exterior e apoio para o intercâmbio de intelectuais estrangeiros nas universidades norte-americanas. Pells (1997, p.22).

43 Ninkovic (1991, p.18) diagnostica a aliança entre fundações e ALA, a motivação de caráter missionário dessa e as dificuldades dos métodos das bibliotecas americanas na América Latina.

44 Para Pells (1997, p.27) fundações como a Rockefeller importaram não só os acadêmicos (que seriam úteis nos programas de informação americana durante a $2^{\mathrm{a}}$ Guerra), mas a cultura e a civilização europeia para os EUA no entre-guerras. 
a estrangeiros, da cooperação técnica e artística, e da abertura de bibliotecas americanas no exterior. Essas ações filantrópicas aconteceram ao mesmo tempo em que as grandes corporações de meios de comunicação (como o rádio e cinema) ocupavam cada vez mais espaço no mercado mundial e garantiram a ampliação da presença americana no cenário internacional nas décadas de 1920 e 1930.

\subsection{FDR e o aparato montado para a $2^{\text {a }}$ Guerra: Birô, OWI e OSS}

Mais uma missão de boa vontade e declaramos guerra aos Estados Unidos.

(Oswaldo Aranha $)^{45}$

O Presidente Roosevelt, que havia sido chefe de gabinete da missão do CPI em Nápoles, quando secretário-assistente da Marinha (Arndt, 2005, p.33) durante a $1^{\text {a }}$ Guerra, em um primeiro momento se dedicou fundamentalmente às demandas sociais e econômicas internas dos Estados Unidos pós-crise de 1929.

Só no fim da década de 1930 - com a preocupação pela forte presença italiana e alemã na América Latina (Pells, 1997, p.33), bem como pela iminência da entrada americana na $2^{a}$ Guerra Mundial -é que o Governo e o Congresso norte-americano começaram a discutir e propor uma estratégia para o combate ideológico contra a propaganda oficial nazifascista.

O marco inicial do governo Roosevelt, para a cooperação cultural e educacional internacional, teve foco na América Latina, principalmente por causa da presença cada vez maior da propaganda e do comércio com a Alemanha nesses países. Pela primeira vez desde o

45 Cull (2005, p.13); Moura (1987, p.49). Segundo Cull (ibidem), o ministro brasileiro das relações exteriores declarou isso em tom de brincadeira, após receber seguidas missões americanas de cooperação, como maestros de orquestras, estrelas de cinema e escoteiros americanos. 
CPI de Creel, o governo americano se voltou para essas questões, criando em 1936 uma plataforma de cooperação científica e cultural para os países latino-americanos, durante a Conferência Interamericana de Manutenção da Paz, em Buenos Aires. ${ }^{46}$

Nessa ocasião, a delegação americana propôs que o seu governo financiasse o intercâmbio entre professores, estudantes universitários e professores de escola secundária dos EUA e países latino-americanos. O programa foi aprovado pelo Congresso e começou a ser executado pelo Departamento de Estado, pela primeira vez, a partir de $1940 .{ }^{47}$

Como decorrência dessas atividades, em maio de 1938 o governo criou (por decreto presidencial) o Interdepartamental Committee for Scientific and Cultural Cooperation with the American Republics. ${ }^{48}$ Em julho desse mesmo ano, criou a Division of Cultural Relations, dentro do Departamento de Estado. Essas iniciativas, com foco principal no continente americano, apresentavam um caráter de cooperação cultural e educacional, mais do que "informacionais". ${ }^{49}$

Mas não só os interesses culturais e ideológicos eram motivo de atenção do governo norte-americano na América Latina do final dos anos 1930. A aliança já existente entre meios de comunicação de massa e interesses econômicos no continente latino-americano também deveria ser preservada. Naquela altura, as atividades das cadeias de rádio como CBS e NBC eram bem sucedidas no mercado latino-americano; tinham como patrocinadoras grandes empresas americanas, como United Fruit Co. e Standard Oil. A operadora de ondas curtas de Cincinatti, Crossley Company, também contava com patrocínio de empresas como Kleenex, Alka-Setltzer, Palnter's

46 Documento 27, p.2.

47 Documento 27, p.3.

48 Segundo Arndt (2005, p.60), o Indepartmental Committee ofereceu 3.700 bolsas de intercâmbio para latino-americanos entre 1938 e 1948.

49 O foco inicial, nesses casos, eram a reciprocidade cultural, de mão dupla, e a longo prazo. Mais detalhes sobre essas primeiras iniciativas de cooperação cultural na América Latina, Henderson (1969, p.29); Elder (1968, p.35); Pells (1997, p.34). 
Peanuts e Carter's Little Liver Pills, em suas transmissões para o subcontinente Dizard Jr. (2004, p.24).

Diante da presença nazifascista nos países latino-americanos, a resposta norte-americana começou a ser pensada na forma de política de informação nos moldes do CPI ${ }^{50}$ mas já diante de uma nova realidade de interesses econômicos e levando em consideração os novos meios de comunicação de massa.

Como líder dessa nova empreitada do governo, foi escolhido Nelson A. Rockefeller, ${ }^{51}$ uma pessoa que reunia várias facetas, como: a experiência nos negócios com América Latina (a família Rockefeller controlava a Standard Oil, entre outros variados empreendimentos na região); a experiência na área de artes (o museu de arte moderna de Nova York/MoMA, também tinha sido uma iniciativa da família); a experiência na área da cooperação técnica e educacional (a Rockefeller, como já observado, era uma das principais fundações americanas); a experiência na direção de grandes empreendimentos, como o Rockefeller Center, o maior centro empresarial do mundo de então.

Em 16 de agosto de 1940, foi criada a primeira das agências americanas de informação que surgiriam no âmbito da $2^{\text {a }}$ Guerra, o Office of the Coordinator of Commercial and Cultural Relations between the American Republics, chefiado por Nelson A.

50 Segundo Arndt, (2005, p.31) Rockefeller repete e potencializa o modelo de articulação entre propaganda, entretenimento, cooperação e interesses econômicos americanos, iniciada pelo CPI de Creel. Ele também chama Ivy Lee, ex-assessor de relações públicas do CPI para assessorá-lo. Assessoria de Lee também citada em Tota (2000, p.47).

51 Sobre o perfil de Nelson Rockefeller, a maioria dos livros sobre diplomacia pública e história da USIA descrevem esse mesmo perfil. Desde os mais recentes, como Dizard Jr. (2004, p.9); Arndt (2005, p.31); Cull (2005, p.12) e Reich (1996); até os mais antigos, como Henderson (1969, p.30); Gellman (1979), Ninkovic (1981, p.35-36) e Elder (1968, p.34). Na bibliografia brasileira, destacam-se os historiadores já citados Moura (1987) e Tota (2000). Outras referências americanas que se dedicam especificamente sobre Nelson Rockefeller e o Brasil são Cobbs (1992) e Colby; Dennett (1998). 
Rockefeller. ${ }^{52} \mathrm{O}$ Birô, uma agência semi-independente do Departamento de Estado, ${ }^{53}$ era responsável por articular a informação, a cultura, os interesses econômicos e a cooperação na América Latina durante a guerra. ${ }^{54}$

Diante da iminência da entrada dos EUA na $2^{\text {a }}$ Guerra, o Birô de Rockefeller propunha uma agenda unilateral que cumprisse seus objetivos no curto prazo. Seus métodos, portanto, deveriam ser apropriados para o cumprimento desses objetivos. Em reunião do Departamento de relações culturais do Birô, em setembro de 1940, Rockefeller deixava claro que a boa vizinhança não era o foco naquele momento, mas sim impor uma interpretação norte-americana, unilateral, na América Latina: "a grande ênfase deve ser na interpretação dos EUA para América Latina e não o contrário”. ${ }^{55}$

Naquele momento, a cultura era vista como uma arma estratégica para a defesa americana. Para Rockefeller, defender a primazia das ideias americanas no continente era tão importante quanto evitar uma invasão militar: "imperialismo intelectual, o imperialismo das ideias era, naquele momento, tão ameaçador quanto o risco à segurança e à defesa do hemisfério, da possibilidade de uma invasão militar.". ${ }^{56}$

52 Elder (1968, p.34). Esse mesmo órgão, depois chamado de Office of the Coordinator of Inter-American Affairs (CIAA) e depois de Office of Inter-American Affairs (OIAA) será chamado ao longo desta obra de Birô, de acordo com a denominação adotada por Gerson Moura (1987), mais antigo estudo brasileiro sobre as ações do Birô de Rockefeller no Brasil a que tive acesso.

53 A caracterização do Birô como semi-independente do Departamento de Estado foi feita por Dizard Jr. (2004, p.24).

54 Henderson (1969, p.30). Segundo Arndt (2005, p.XVIII), até 1938 o Estado norte-americano só participava de $5 \%$ das ações do total do intercâmbio cultural na América Latina, até então uma via de mão dupla ("free-flowing, two-way cultural relations"). A partir da criação do Birô, esse quadro mudaria.

55 Ninkovic (1981, p.36): [CIAA Policy Board minutes, 27 September 1940, Papers of William Benton, privately held, Box 5712; Minutes of meeting in Charles Thomson's office, 30 September 1940, in ACLS MSS, Box B-95].

56 Idem. [U.S., Office of Inter-American Affairs, History of the Office of the Coordinator of Inter-American Affairs (Washington, D.C.: Government printing office, 1947), p.7n; U.S., Congress, House, Subcommittee of the Committee on 
Assim como fazia o CPI, o Birô, que tinha seu comando central em Washington D.C., operava por meio dos postos locais (USIS) localizados nas embaixadas e consulados. Além disso, da mesma forma que o comitê de Creel, o Birô incentivou a criação de centros binacionais, ${ }^{57}$ em aliança com comunidades locais pró-EUA, multiplicando o número de bibliotecas ${ }^{58}$ para promover os EUA politicamente e a reforçar os interesses das empresas americanas.

Com isso, durante a sua existência, o Birô de Rockefeller multiplicou exponencialmente o seu orçamento e pessoal, passando dos iniciais US\$ 3,5 milhões para US\$ 144 milhões no período até 1944 (Colby; Dennett, 1998, p.143), chegando a ter 1100 funcionários nos Estados Unidos e 200 no exterior (Cobbs, 1992, p.39; Moura, 1987, p.10). Só para o ano de 1945, o orçamento era de US\$ 30 milhões, dez vezes maior que o orçamento anual de $1940 .{ }^{59}$

Por trás do aumento das atividades culturais do Birô, obedecendo ao padrão das ações de informação americanas desde Creel, estavam os interesses econômicos na região. E em época de conflito, garantia o abastecimento ${ }^{60}$ das matérias-primas necessárias para a Guerra.

Appropriations, Hearings, Second Deficiency Appropriation Bill for 1941, 77th Cong., 3rd sess., 1940, p.684-92.].

57 Para Cull, (2005, p.12), o centros binacionais foram irradiadores da política unidimensional de informação do Birô, que mesclava interesses comerciais e projetos culturais já existentes, partindo da América Latina para o mundo. Arndt (2005, p.10) também vê na capilaridade e modo de agir dos centros binacionais, uma das principais heranças do Birô de Rockefeller para o esforço ideológico americano no mundo a partir de então. Segundo Dizard Jr. (2004, p.181), o primeiro centro binacional no Brasil, no modelo do que seria replicado depois, foi fundado no Rio de Janeiro, em 1937, antes mesmo da criação do Birô.

58 Arndt, (2005, p.85) nota que a experiência latino-americana com bibliotecas do Birô (inspirada em ação anterior de Creel) também reforçou o caminho para as futuras bibliotecas da USIA no mundo todo.

59 Arndt (Id., p.90).

60 Para Colby; Dennett (1998, p.143), o glamour das turnês de artistas e exposições do Birô, que cresciam sem parar, era uma cortina de fumaça que ocultava a agenda norte-americana de "arrastar a América Latina para a matriz econômica dos programas de abastecimento de guerra executados por lideranças empresariais". Tota (2000, p.57) comenta que Rockefeller convenceu as grandes empresas americanas a patrocinarem as atividades do Birô, mesmo sem ter o que 
O programa de centros binacionais, de responsabilidade do Birô, foi gerido localmente por uma organização da sociedade civil (o que também faz parte do perfil das ações de informação norte-americana) o American Council of Learned Societies (ACLS), de julho de 1942 a junho de $1943 .{ }^{61}$ O ACLS teve dificuldade para encontrar pessoal local que falasse inglês e dedicou seus primeiros esforços para qualificação dos funcionários da região e na criação dos acervos de materiais didáticos e equipamentos para bibliotecas locais.

A partir de julho de 1943, a divisão de relações culturais do Departamento de Estado começou a gerir o programa de centros binacionais na América Latina (depois chamado de Cultural Centers Program), custeando cerca de $20 \%$ das despesas operacionais dos centros (US\$ 42.700). O restante (80\%) era bancado por contribuições e financiamentos locais, como mensalidades e aulas de inglês, cobradas dos alunos. Em 1946, o programa já contava com 27 centros culturais no continente e o governo norte-americano pagava o salário de 20 diretores e 27 professores de inglês, arcando com cerca de US\$110 mil em salários e de US\$ 50 mil em materiais, por ano.

O Birô de Rockefeller tinha dois principais eixos de ação (Cobbs, 1992, p.39): o eixo de propaganda, desempenhada pela divisão de publicações e informação; ${ }^{62}$ e o eixo de cooperação hemisférica, ${ }^{63}$ desempenhada pelas divisões de alimentação e de saúde. ${ }^{64}$ Da mes-

vender. Tota (2000, p.82) também descreve o interesse americano na borracha brasileira para o seu uso durante a $2^{\mathrm{a}}$ guerra.

61 Documento 14.

62 Como cunhado por Creel, o termo informação para designar as atividades de propaganda aparecia nesse momento com a mesma conotação. Tota (2000, p.55) também fala sobre a preocupação dos "altos funcionários" do Birô em não usar o termo "propaganda".

63 Para Dizard Jr. (2004, p.10), ações de cooperação do Birô em áreas como a habitação e construção de estradas serviram como modelo para os programas de cooperação internacional do pós-guerra, como a USAID.

64 Segundo Moura (1987, p.10), o Birô tinha uma estrutura com quatro divisões: a de comunicações (que englobava rádio, cinema, imprensa, viagem e esportes); a divisão de relações culturais (que lidava com arte, música, literatura, publicações, intercâmbio e educação); a divisão de saúde (principalmente saneamento) e divisão comercial/financeira (para exportação, transporte, finanças e 
ma maneira que havia pensado Creel, o Birô também se utilizou dos métodos de relações públicas e pesquisa de mercado (estudos qualitativos e quantitativos), práticas utilizadas pelas agências de propaganda para atingir os mercados latino-americanos. ${ }^{65}$

No comando da divisão de informações estava o jornalista Frances Jamieson, ${ }^{66}$ responsável pelas equipes ${ }^{67}$ que produziam material para jornais e revistas. Além de publicações próprias, o Birô também traduzia e adaptava exemplares semanais do New York Times (Cobbs, 1992, p.39), além da Reader's Digest (revista Seleções) para o público latino-americano (Moura, 1987, p.34; Tota, 2000, p.59).

Entre as publicações de mais sucesso estava o Em Guarda, que chegou a alcançar uma circulação mensal de 500 mil exemplares na América Latina (só no Brasil, em 1943, a tiragem era de 658 mil folhetos, sendo que os estudos do Birô apontavam que cada cópia era lida por cinco leitores, em média). ${ }^{68} \mathrm{O}$ sucesso foi tanto que as

desenvolvimento). Para Tota (2000, p.51) o Birô tinha três divisões (comercial/ financeira, comunicações e relações culturais).

65 Cobbs (1992, p.42) comenta que Rockefeller adotou técnicas da publicidade se utilizando sempre de estatísticas, gráficos, tabelas e projeções como métodos de seu trabalho. Segundo Tota $(2000$, p.60, 61) Rockefeller buscou auxílio de George Gallup e seu instituto para pesquisas na região. Arndt (2005, p.89) comenta que Rockefeller coordenava as atividades de pesquisa com as de "inteligência”, usando informações estratégicas para atividades de contra-informação (grey propaganda).

66 Jamieson era jornalista premiado, ganhador do prêmio Pulitzer. Seu trabalho na divisão de informação do Birô inspirou o modelo seguido no Office of War Information e mais tarde a USIA. Cobbs (1992, p.39) e Tota (2000, p.55).

67 A divisão de informações contava também como uma equipe de pesquisa. Moura (1987, p.33) cita como fundamental o trabalho do historiador de relações internacionais, o americano Dr. Charles Chandres, que "mediante intensa atividade de pesquisa, palestras e publicações tornou possível o desenvolvimento do tema de que as relações brasileiro-americanas não eram um expediente de momento, mas tinham razão em muitos anos de história”. O Birô, como será visto mais adiante, também financiou o intercâmbio de jornalistas e escritores brasileiros e americanos. Tota (2000, p.56) cita que mais de 200 jornalistas trabalharam na divisão nos EUA, entre eles os brasileiros Orígenes Lessa, Marcelino de Carvalho, Raimundo Magalhães e Carlos Cavalcante.

68 Moura (1987, p.35). O “Em Guarda” era uma versão da revista Life, para o público latino. Segundo Arndt (2005, p.83), Rockefeller mobilizou Henry Luce 
revistas Em Guarda eram roubadas das caixas de correio para serem lidas. A Alemanha, sem o mesmo sucesso, tentou fazer uma versão da revista, mas com uma visão pró-germânica e antiamericana, que se chamava De Guarda. ${ }^{69}$

Para garantir uma relação privilegiada com os proprietários de jornais no Brasil, o Birô facilitou e incentivou o trabalho daqueles jornais que se mostravam pró-americanos. O Birô subsidiou e facilitou as importações de papel jornal, que estava escasso por conta da Guerra, para as empresas brasileiras. Além de romper as barreiras de importação, o papel jornal era garantido aos pró-EUA, sendo levado por navios americanos. ${ }^{70}$

O Birô também produziu programas de rádio próprios para a América Latina, principalmente com atenção para as transmissões em ondas curtas, com treinamento de radialistas latino-americanos em conjunto com emissoras de rádio americanas e parcerias com estações da região (Colby; Dennett, 1998, p.141; Tota, 2000, p.73, 78; Dizard Jr., 2004, p.24; Cull, 2005, p.12-13). Os programas produzidos pelo Birô combinavam informação (pró-americana) e entretenimento, formando o modelo que seria adotado pela rede e canais Voice of America (Dizard Jr., 2004, p.10, 24).

Moura (1987, p.21) descreve com detalhes os programas de rádio do Birô no Brasil:

... a seção de rádio do Birô no Rio de Janeiro podia orgulhar-se em 1943 de distribuir programas de notícias para 92 estações de rádio brasileiras. Um sem-número de programas ouvidos pelos brasileiros em seus rádios provinha do Birô. Era o caso de "A Marcha

(proprietário da Time, Life, Sports Illustrated, entre outras revistas) e os editores da Life, para ajudar na produção da "Em Guarda".

69 Cull (2005, p.12, 13). Tota (2000, p.56) comenta que o nome inicial proposto para a revista seria "Em Marcha", mas vetada pelo secretário de Estado Cordell Hull por parecer muito agressiva, e assim foi chamada de "Em Guarda”, que passava a ideia menos violenta.

70 Segundo Colby; Dennett (1998, p.142), mais de 1.200 donos de jornais da América Latina foram beneficiados com o papel jornal americano. 
do Tempo", "Rádio Teatro", "Canções da América", "Espírito da Vitória" e "Sim ou não". O programa "A marcha da Guerra" entremeava comentários informais às principais notícias do dia, além de entrevistar altas autoridades sobre a "perspectiva brasileira" a propósito da marcha da guerra. Novidades naquele mesmo ano de 1943 foram: "Família Borges" (que colocava uma família brasileira nos Estados Unidos observando o estilo americano); "Barão Eixo" (que procurava responder à propaganda de rádio de Berlim, transmitida para o Brasil); e "O Brasil na guerra" (acentuando a contribuição brasileira aos Aliados).

Em trabalho conjunto com os grandes estúdios de Hollywood, que tinham suas salas de cinema próprias na América Latina, o Birô conseguiu impedir a exibição de filmes e cinejornais italianos e alemães nestas salas, os substituindo pelos newsreels e filmes próprios. Para isso, produziu conteúdo próprio com grandes diretores de Hollywood em filmes e documentários ${ }^{71}$ que mostravam o lado positivo dos Estados Unidos e características comuns dos países do continente. $^{72}$

Em 1941, o Birô (em conjunto com o estúdio RKO) contratou Orson Welles para um documentário que demonstraria a amizade entre os povos das Américas, mas esse nunca fora finalizado. ${ }^{73} \mathrm{Em}$ 1942, foi lançado um dos exemplos mais citados desse esforço de

71 Alguns dos documentários do Birô estão disponíveis na Internet. Um exemplo é o filme feito sobre a pujança do Estado de São Paulo. Disponível em: $<$ https://www.youtube.com/watch? v=InWifglIkQ0\&eurl=http://colunistas. ig.com.br/flaviogomes /\&feature=player_embedded $>$ Acesso em: 11 out. 2014.

72 Colby; Dennett (1998, p.141). Tota, (2000, p.63 a 73), também descreve as relações do Birô em produções de Walt Disney, Frank Capra e Orson Welles, além dos newsreels.

73 Dizard Jr. (2004, p.167). O documentário "It's All True”, de 1993, dirigido por Richard Wilson, Bill Krohn e Myron Meisel, conta a saga de Welles no Brasil e a importância disso em sua carreira subsequente. Tota, (2000, p.71), também descreve o trabalho de Welles no Brasil, tanto na produção de seu filme, quanto em programas de rádio. 
guerra em Hollywood, a animação "Alô Amigos", produzida pelo Birô e realizada por Walt Disney. É quando surge o personagem Zé Carioca, que apresenta o Brasil ao marinheiro americano Pato Donald..$^{74}$

Por fim, Rockefeller, em trabalho conjunto com museus americanos e o Departamento de Estado, ${ }^{75}$ também organizou turnês artísticas e intercâmbios de músicos, artistas modernos e intelectuais americanos e latino-americanos.

No entanto, apesar de pioneiro, o Birô não foi a única frente de trabalho na área da informação americana no exterior. Com a iminência da entrada dos EUA na Guerra, o Presidente Roosevelt criou diferentes Departamentos que posteriormente também se mesclariam e viriam a ser importantes influências para o trabalho a ser retomado pela USIA no pós-2 ${ }^{\text {a }}$ Guerra.

Em julho de 1941, Roosevelt nomeou William B. Donovan como coordenador de informação de seu governo e cria, abaixo dele, o Foreign Information Service (FIS), chefiado por Robert E. Sherwood (Elder, 1968, p.34; Henderson, 1969, p.30). Em 1941 foi criado, no Departamento de Estado, o Office of Facts and Figures (OFF), ${ }^{76}$ comandado por Archibald Macleish, para organizar as pesquisas e ser um think-tank para pensar, a longo prazo, a defesa (também ideológica) do país durante e para o pós-guerra.

Um pouco mais de dois meses após o ataque a Pearl Harbor, ${ }^{77}$ em 24 de fevereiro de 1942, o Voice of America (VOA) ${ }^{78}$ começou a

74 Mais sobre o Zé Carioca e a política de boa vizinhança na dissertação de Herz, (1986) e também em Tota (2000, p.72), que data a exibição de "Alô Amigos" em 1943. Entre autores estrangeiros podemos citar menções em Cobbs, (1992, p.39-40), Cull, (2005, p.12-13).

75 Cobbs (1992, p.39-40); Cull (2005, p.12-13). Segundo Dizard Jr., (2004, p.10), esse intercâmbio artístico do Birô, impulsionado por Nelson A. Rockefeller, também criou importante precedente para o que a USIA viria a fazer.

76 Henderson (1969) e Arndt (2005, p.87) destacam a participação de acadêmicos importantes como Harold Lasswell (cientista político e estudioso da Teoria da Comunicação), o historiador Arthur Schlesinger, entre outros, no Office of Facts and Figures, durante a 2 a Guerra.

77 Que ocorreu em 7 de dezembro de 1941.

78 Segundo Henderson (1969, p.31), o VOA já era transmitido pela emissora WRUL anteriormente, mas o seu começo efetivo é considerado a partir de 
ser transmitido em ondas curtas, começando a levar a versão do governo americano da história (Pells, 1997, p.34) para todas as partes do mundo.

Em 13 de junho de 1942, Roosevelt criou o Office of War Information (OWI), que ficou responsável por idealizar e difundir as informações, interna e externamente, com exceção da América Latina, que para isso tinha o Birô. Para o comando do OWI, que contava com 26 postos USIS na Europa, África e Leste asiático (Hixson, 1997, p.2; Pells, 1997, p.34; Tota, 2000, p.84), Roosevelt nomeou Elmer Davis, escritor, acadêmico e radialista da CBS. Como seu assessor e substituto (deputy), Davis escolheu Milton Eisenhower, que já havia sido responsável pelo Departamento de Informação do Ministério da Agricultura nos anos 1930 (Arndt, 2005, p.87). O FIS, criado um ano antes, passa a ser o braço estrangeiro do OWI, e continuou a ser chefiado por Sherwood (Elder, 1968, p.34). O OWI também acabou absorvendo o Office of Facts and Figures, de MacLeish.

O OWI adaptou algumas das atividades já realizadas pelo Birô para as realidades dos outros continentes e, sobretudo, para o público interno. Esse gabinete trabalhava em consonância com Hollywood, visando mobilizar o público interno semanal de 80 milhões de pessoas ${ }^{79}$ nos cinemas americanos. Externamente fortaleceu, principalmente, o VOA. ${ }^{80}$

Além disso, tanto o OWI quanto o Birô, em parceria com o Departamento de Estado, fortaleceram ainda mais o intercâmbio de

fevereiro de 1942. Segundo Elder (1968, p.34), Robert Sherwood, chefe do FIS, participou da primeira transmissão doVOA.

79 Hixson (1997, p.2) comenta que foi formada uma aliança entre o OWI e Hollywood para justificar e ganhar legitimidade para o esforço de guerra.

80 Bogart (1995, p.xiii) vê nas ações do OWI, de Davis, uma clara inspiração do CPI de Creel, e nas ações britânicas durante a $2^{\text {a }}$ Guerra. Segundo Bogart, o VOA também foi criado com base nas transmissões externas da BBC. Para ele, a doutrina de propaganda americana do "Truth is our weapon", só acabaria com os comunicados de imprensa do Pentágono para a guerra do Vietnã, durante o governo Johnson, que não tinham preocupação de informar ou justificar moralmente as ações norte-americanas. 
intelectuais, formadores de opinião e lideranças locais, ${ }^{81}$ principalmente as que se mostravam independentes ou resistentes em apoiar a causa americana. O Departamento de Estado oferecia um programa de 3 semanas de intercâmbio a estrangeiros com esse perfil (o Exchange of Persons Program).

Relatórios e estudos internos, como o produzido por Leo Bogart, ${ }^{82}$ comentam que o foco do programa era convencer estrangeiros formadores de opinião que ainda não haviam se decidido se eram pró-americanos. Mas, em relação aos estrangeiros cultos e com espírito critico, o programa poderia provocar o efeito contrário, já que esses poderiam notar as verdadeiras intenções do governo. Outro efeito negativo seria, caso houvesse a americanização, a rejeição do formador de opinião em seu país de origem, pois poderia ser visto pelos seus conterrâneos como "americanizado" ou "comprado" (Bogart, 1995, p.189).

Entre os brasileiros, de 1941 a 1944, lideranças em várias áreas foram "premiadas" com a bolsa de intercâmbio da política de boa vizinhança. Estiveram nos EUA em 1941, entre outros: Jorge Americano (promotor público, deputado, que assumia a reitoria na Universidade de São Paulo naquele mesmo ano); Sergio Buarque de Hollanda (historiador); Pedro Calmon (advogado, na ocasião ex-deputado e futuro ministro de Dutra), e Érico Veríssimo (escritor e jornalista). ${ }^{83}$

81 Para Arndt (2005, p.92), a atração de líderes estrangeiros é política americana desde a Conferência Inter-Americana de 1885, e que se reforça principalmente a partir de 1938. Segundo o autor, esta atividade tem caráter unidimensional: os estrangeiros vão aos Estados Unidos para aprender, os americanos vão aos outros países para ensinar.

82 Em junho de 1953, o cientista social Leo Bogart coordenou um grupo de pesquisadores da Universidade de Columbia, a pedido da recém-criada USIA, para uma pesquisa qualitativa (com base em entrevistas dos funcionários e documentos) sobre as ações de informação norte-americanas até então. O estudo completo, disponível nos arquivos nacionais americanos (NARA/College Park), foi compilado e lançado como livro em 1997, com o título "Cool words, cold war: a new look at USIA's premises for propaganda". Esses e outros estudos serão observados nos capítulos subsequentes.

83 Documento 26. 
Segundo o próprio Veríssimo (1984, p.43), ele foi convidado pelo Departamento de Estado para passar 3 meses nos Estados Unidos, "para viajar, conhecer pessoas e coisas, e se necessário, fazer conferências (se não houver outro remédio)". O diário de bordo dessa experiência resultou no livro "Gato preto em branco de neve".

Veríssimo (ibidem, p.214), recebido e acompanhado por funcionários do Departamento de Estado, ${ }^{84}$ encontrou escritores, artistas e intelectuais e fez palestras em universidades americanas. No geral, mostrou simpatia pelos programas sociais de Roosevelt (como o “relief', que ajudava os desempregados a sustentarem suas famílias), se espantou positivamente com as grandes cidades ${ }^{85}$ e com políticos americanos (chamou o prefeito de Nova York, La Guardia, de "Pequeno Napoleão”) (ibidem, p.192), mas ao mesmo tempo demonstrou uma visão crítica à política de aproximação dos Estados Unidos com intelectuais estrangeiros.

Ao se hospedar em alojamento estudantil em Chicago, Veríssimo (ibidem, p.251) descreveu a experiência que teve na International House, assim como na nova-iorquina de Riverside Drive (financiada pela família Rockefeller), desconfiando da boa vontade americana e se solidarizando com outros bolsistas, na mesma situação:

Nesta casa, como na de Nova York, hospedam-se estudantes de várias partes do mundo. Tive esta manhã à minha mesa um escuríssimo doutor da Índia, uma moça de Kansas e um cabeçudo e pensativo filho do Iraque. Tenho a impressão que somos pobres "nativos", afilhados duma senhora muito rica e caritativa - madrinha América - que nos dá prêmio de viagem, bolsas de estudo e

84 Quem o recebe nos Estados Unidos é um funcionário do Departamento de Estado que falava português, Richard Patee, segundo Veríssimo (1984, p.45) "um tipo saudável e simpático”.

85 Veríssimo (1984, p.46) ao descrever a $5^{\text {a }}$ avenida, em Nova York, teve um impacto positivo: "Lanço um olhar rápido para a perspectiva da mais famosa avenida do mundo: um enorme cânion a fugir para o céu lírico: as calçadas fervilhantes duma humanidade ativa e sortida: a rua coalhada de veículos em movimento". 
matrículas gratuitas, para que sejamos sempre bons meninos. E por isso que eu me sinto um pouco parente daquela havaiana que ali está lendo ao pé da janela ogival, do mulato de São Domingo que agora atravessa o hall com ar desconfiado e daquele melancólico japonês que há vários minutos está brincando com a corrente do relógio, sob a luz duma lâmpada velada.

Ao final da viagem, Veríssimo (1984, p.176) encontrou o escritor, jornalista e historiador Hendrik W. Van Loon, holandês naturalizado americano, que também apresentava diagnóstico crítico da política de boa vizinhança:

Boa vizinhança é besteira - diz ele. - Você acredita em goodwill e em todas estas bobagens? Se você gosta de mim, vem à minha casa, conversa comigo, come à minha mesa e amanhã eu faço o mesmo na sua casa. Tudo isso natural, sem discursos ou publicidades. Passamos a vida inteira ignorando a América do Sul. E agora, de repente, toca a fazer boa vizinhança a todo vapor! É ridículo.

Veríssimo acaba voltando aos Estados Unidos, de 1943 a 1944, também com uma bolsa do Departamento de Estado para intercâmbio de acadêmicos, como professor visitante de literatura brasileira, na Universidade da Califórnia. Esse segundo período nos Estados Unidos é descrito no seu segundo livro sobre sua estada naquele país: A volta do gato preto (escrito em 1947).

De 1942 a 1944, fizeram parte do programa de intercâmbio, entre outros brasileiros: o compositor Francisco Mignone; o historiador Dante de Laytano; a escritora Nilda Bethlen; um dos primeiros geneticistas brasileiros e um dos fundadores da USP, André Dreyfus; o médico Heitor Froes; as assistentes sociais Maria Kiehl e Maria Junqueira Schmidt e os jornalistas Sérgio Milliet e Francisco de Assis Chateaubriand (que dispensa apresentações). ${ }^{86}$ 
Entre as figuras de destaque no Brasil, Heitor Villa-Lobos se apresentou no Panamá, em Cuba e nos Estados Unidos, com apoio do Birô e do Museu de Arte Moderna de Nova York (administrada pelos Rockefeller), ${ }^{87}$ regendo a orquestra americana de Werner Janssen. A exibição de Villa-Lobos com a sinfônica de Janssen teve a sua apresentação no auditório filarmônico de Los Angeles transmitida por rádio (em ondas curtas) para todo o continente e também devidamente registrada em fotos e filmes, exibidos por todo continente. ${ }^{88}$

No Brasil, apesar de muitas críticas às missões de boa vizinhança (como a citada por Veríssimo, ou até na fala do ministro Oswaldo Aranha, epílogo do subcapítulo), alguns intelectuais americanos deixaram impressões positivas no país. Segundo Moura (1987, p.50):

É claro que havia exceções louváveis entre os que vieram ao Brasil e não usavam os óculos do preconceito e do utilitarismo empresarial ou político. Cientistas sociais como Herskowitz e Wagley produziram nessa época textos relevantes sobre o Brasil, discrepando frequentemente da visão primária e utilitária que fluía dos escritos oficiais do governo americano.

No período de 1940 a 1946, entre os acadêmicos americanos que vieram ao Brasil (na maioria das vezes também com bolsas de 3 a 4 meses de duração e estágios em alguma universidade brasileira), sete ficaram na Universidade do Brasil (Rio de Janeiro), cinco na Universidade de São Paulo, dois na Escola de Sociologia e Política de São Paulo e um na Escola Paulista de Medicina. No total, vieram ensinar no Brasil 15 professores, enquanto apenas um professor brasileiro esteve nos EUA com a mesma função. ${ }^{89}$

87 Documento 26. Interessante notar que, nos documentos de organização da turnê de Villa-Lobos se revezavam cartas timbradas do Birô com cartas registradas do Museu de Arte Moderna de Nova York, sobre os mesmos assuntos.

88 Documento 25. A apresentação em Los Angeles ocorreu em 19 de novembro de 1944.

89 Documento 27, p.4. Até 1946, o único professor brasileiro nos EUA foi Érico Veríssimo. De 1946 a 1948, outros três professores brasileiros deram aulas em universidades americanas. 
No mesmo período, o total de estudantes/lideranças brasileiros que estiveram nos EUA para "aprender" foram 59, enquanto estiveram no Brasil seis estudantes/lideranças americanas. ${ }^{90}$

Mesmo com toda possível crítica dos intercambistas, os programas de atração de lideranças e intelectuais estrangeiros alcançaram os seus objetivos e trouxeram ganhos imediatos aos Estados Unidos. Alguns dos intelectuais que voltaram aos seus países ficaram com boas impressões do país, outros ficaram nos Estados Unidos e chegaram a trabalhar com o Departamento de Estado, OWI e OSS, no esforço de guerra (inclusive no pós-guerra). ${ }^{91}$

O próprio Secretário de Estado norte-americano, William Benton, em 1945, alertava para a importância dos programas de intercâmbio no início da era atômica:

O intercâmbio de competências, conhecimento, estudantes, cientistas e outros especialistas é uma ideia relativamente nova e portanto, para alguns, heterodoxa. Não devemos limitar nossas mentes por causa disso. Nós devemos, ao contrário, com o desenvolvimento da bomba atômica e outras armas de destruição aterrorizadoras, fazer nossas apostas pequenas e discretas em medidas de longo prazo, que contenham alguma possibilidade concreta para garantir que o mundo possa viver junto, em paz e entendimento. ${ }^{92}$

Mas nem só de cooperação cultural e acadêmica se baseava a política de informação americana. $\mathrm{O}$ batalhão americano formado por Roosevelt para o "psychological warfare" durante a 2a Guerra, formado pelo Departamento de Estado, o Birô e o OWI, era complementado pelo Office of Strategic Services (OSS), criado em junho

90 Documento 27, p.3.

91 Pells (1997, p.30) cita a contribuição de intelectuais franceses e europeus no combate ideológico da $2^{\text {a }}$ Guerra e no início da Guerra Fria, além de outros campos, como até a concepção e produção da bomba atômica, com o OSS, o OWI e o Departamento de Estado.

92 Documento 27: p.13, "Bulletin of Oct. 21, 1945, p.591”. 
de 1942 e responsável por implementar as ações de inteligência ${ }^{93}$ e de black propaganda, ${ }^{94}$ principalmente no fronte europeu.

Segundo a terminologia dos próprios agentes, a black propaganda é a realizada sem assinatura do governo, ou com uma autoria fictícia/errônea, com objetivo de confundir, ou ludibriar o público a ser atingido. Para Bogart (1995, p.xiii), o OSS era especialista nisso: "'guerra psicológica' (psychological warfare) voltada contra o inimigo - incluindo 'black' propaganda (clandestina) no rádio - foi conduzida pelo Office of Strategic Services".

Arndt vê que, a partir de 1942, as atividades de black propaganda foram incorporadas definitivamente à maneira americana de fazer política de informação: "relações culturais ainda estavam intactas quando, em 1942, as pressões da guerra e um perspicaz Nelson Rockefeller começaram a 'muddying the waters' [enlamear as águas] ... Até o final do século vinte, a ideia de uma diplomacia cultural americana independente foi gradualmente se corroendo" ${ }^{95}$

Quem comandava o OSS era o advogado e herói da 1a Guerra, William D. Donovan, conhecido como "Wild Bill" Donovan, ${ }^{96} \mathrm{o}$ mesmo que tinha sido nomeado por Roosevelt como Coordenador de Informação em setembro de 1941. Durante a $2^{\text {a }}$ guerra o OSS chegou a ter mais de 12 mil agentes em cinco frentes simultâneas de batalha. ${ }^{97}$ Hixson (1997, p.3), citando um ex-funcionário de Donovan, exemplificava o trabalho secreto que era feito pelo OSS: “'Bill Donovan', como um colega lembrou, é o tipo do cara que não

93 Segundo Arndt (2005, p.87), entre outras atividades o OSS formou uma equipe de pesquisadores sociais e historiadores, comandada pelo chefe do Departamento de História de Harvard, William L. Langer, para "melhor entender os inimigos".

94 Como será visto no segundo capítulo, a USIA no Brasil também se utilizou de artifícios parecidos.

95 Arndt (2005, p.xii) foi funcionário da USIA durante décadas.

96 Documento 28. Segundo Dizard Jr. (2004, p.9-13), "Wild Bill” foi autorizado pela Casa Branca para realizar operações secretas e não ter que justificar gastos para suas ações, de acordo com o modelo de "black operations", observadas por Donovan em Londres.

97 Documento 28. 
pestanejava em descer de paraquedas na França, explodir uma ponte, urinar em um tanque de gasolina da Lutwaffe, e depois dançar na cobertura do Hotel St. Regis com uma espiã alemã”.

A profusão dos Departamentos de Informação do Governo durante a $2^{\text {a }}$ Guerra causou uma certa confusão ${ }^{98}$ de competências e criou a necessidade de coordenação das múltiplas ações. Donovan, após perder batalha interna no governo para Rockefeller, ${ }^{99}$ na América Latina, manteve a ação do Departamento local do OSS somente para informar o FBI e Birô sobre simpatizantes do Eixo na região, em ações conjuntas de contrainformação ou apoiando financeiramente as ações de propaganda realizadas pelo Birô (Colby; Dennett, 1998, p.143).

Em 1943, as atividades culturais do Birô foram transferidas para o Departamento de Estado, ${ }^{100}$ e no começo de 1944 Nelson Rockefeller ${ }^{101}$ também se muda para lá (como Assistant Secretary of State for American Republic Affairs). ${ }^{102}$

98 Henderson (1969, p.31), descreve o atrito entre as primeiras ações dos diversos Departamentos comandados por Donovan (o OFF, Office of Government Reports, o FES) que levaram à reorganização interna e a criação do OWI (órgão independente de Donovan, inspirado no CPI de Creel) e do OSS. Ainda segundo Henderson, o Birô se manteve com autonomia na América Latina.

99 Colby; Dennett (1998, p.143). A relação entre Birô e OSS (Rockefeller e Donovan) também é desenvolvida em Tota, (2000, p.85).

100 Elder (1968, p.35). Segundo Bogart, 1995, p.xiii, no começo de 1944 também é criado o Office of Public Information dentro do Departamento de Estado.

101 Moura (1987), Cobbs (1992); Colby \& Dennett (1998) são contribuições fundamentais para o estudo de Nelson Rockefeller no Brasil também no pós$-2^{\text {a }}$ Guerra, na relação com lideranças e políticos brasileiros como Juscelino Kubitschek, com a criação da American International Association (AIA), a Associação de Crédito e Assistência Rural (ACAR) e o International Basic Economy Corporation (IBEC). Antonio Pedro Tota também lançou, no segundo semestre de 2014, um livro sobre Nelson Rockefeller no Brasil, no pós-guerra, intitulado "O amigo americano: Nelson Rockefeller e o Brasil".

102 Cull (2005, p.13). Em seu lugar, como diretor do Birô, assume o arquiteto Wallace K. Harrison (que participou, entre outras realizações, dos projetos do Rockefeller Center e Lincoln Center, em Nova York). Sobre Harrison, sua bibliografia e obra, a Universidad de Columbia disponibiliza parte de sua história e acervo, disponível em <http://www.columbia.edu/cu/lweb/archival/ collections/ldpd_3460617/> Acesso em: 12 out. 2014. 
Em janeiro de 1945, Archibald Macleish assumiu o primeiro cargo de Assistant Secretary of State for Public and Cultural Affairs, órgão do Departamento de Estado que, com o fim da guerra, absorveu as atividades de informação do Birô, do OSS e do OWI ${ }^{103}$ e começou a transição para o novo governo após a morte de FDR. ${ }^{104}$

A mensagem propagada pelo Birô na América Latina mudaria no pós-guerra, mas os seus métodos se expandiriam para o mundo. ${ }^{105}$ Os objetivos da política externa norte-americana, com a nova configuração mundial que se formava, também mudariam, mas a política de informação, cada vez mais necessária e sofisticada, foi mantida e fortalecida. Com o fim da Guerra muitos dos funcionários e dos métodos aplicados pelo OSS também foram reaproveitadas na CIA, criada em 1947. ${ }^{106}$

As diversas agências que se sucederam e reorganizaram as atividades de informação do Birô, do OWI e do OSS no fim e no imediato pós-guerra, prepararam o terreno para a ampliação das atividades de informação dos EUA, inclusive na América Latina e em especial no Brasil, com a formação da USIA, a partir de $1953 .{ }^{107}$

103 Macleish, ex-funcionário do Departamento de Pesquisa do OSS e Assistant Director do OWI durante a $2^{\text {a }}$ Guerra, ficou como Assistant Secretary of State for Public and Cultural Affairs até agosto de 1945. Para Arndt (2005, p.102) Macleish absorveu o trabalho das três agências, mantendo as relações culturais e educacionais no exterior sob o controle do Departamento de Estado, proposta de Sumner Welles, e com apoio do Presidente.

104 FDR faleceu em 12 de abril de 1945 deixando o cargo para Harry S. Truman.

105 Segundo Moura (1987, p.88), os interesses americanos mudaram, passando de "colaboração hemisférica" para "defesa da civilização ocidental" e "mundo livre”, incorporando os métodos do Birô nas novas agências que foram criadas no pós-guerra.

106 Documento 28. Nos últimos anos de vida, na década de 1950, Bill Donovan trabalhou na compilação e pesquisa profunda sobre atividades de espionagem norte-americana desde antes da sua independência como nação. Após a sua morte, em 1959, o acervo de Donovan, e de sua pesquisa, foi doado para a Universidade de Colúmbia, onde pode ser consultado.

107 Segundo Elder (1968, p.35), o Birô e o OWI são os verdadeiros pais da USIA. 


\section{Truman e a readaptação das estruturas da $2^{a}$ guerra para a Guerra Fria}

Ao assumir a presidência em 12 de abril de 1945, com a 2a Guerra em seu desfecho, Truman começou o desafio de fazer uma complexa transição ${ }^{108}$ da política externa norte-americana para a configuração bipolar que se formaria no pós-guerra. As estruturas de informação dos EUA no exterior também passariam por essa mudança, mas com desdobramentos diferentes da que sofreram no pós-1ª Guerra: as agências acabaram, mas suas ações continuaram em novos Departamentos e órgãos criados.

Na sessão final da conferência de San Francisco, ${ }^{109}$ Truman já apontava para a importância do intercâmbio de ideias e da criação de uma agência específica para esse fim, no âmbito da recém-criada Nações Unidas: "Nós temos que estabelecer uma agência permanente para o intercâmbio profundo e constante de pensamentos e ideias". ${ }^{110}$

Internamente, o Presidente enfrentava uma forte pressão da sociedade e do Congresso norte-americano para acabar com as agências de informação. Mas ao contrário do que foi feito no pós-guerra anterior, Truman não acabou com a maioria das ações em andamento, e sim as adaptou para uma nova fase da política externa americana e mundial. Ao longo de seu governo, Truman readequou as agências de informação com base em um novo contexto internacional que se formava.

Como será visto mais detalhadamente a seguir, ao longo deste subcapítulo, os programas de informação dos EUA sofreram sucessivas modificações e ajustes durante os oito anos de Truman, processos que culminaram com a criação da USIA, em 1953. Os programas de informação durante o governo Truman podem ser divididos em

108 Haines (1989, p.xi), destaca o período de 1945 a 1954, como o grande momento de transição da política externa norte-americana.

109 Documento 14.

110 Discurso de Truman, de 26 de junho de 1945 em Documento 14. 
quatro fases $^{111}$ (de 1945-1947, de 1947-1949, de 1950-1951 e de 1951-1953, cada uma com um responsável, com ênfases culturais e/ ou informacionais e Departamentos diferentes).

Segundo Cull (2005, p.22-3), a primeira fase, de 1945 a 1947, sob o comando do William Benton, que sucedeu Macleish como Assistant Secretary of State for Public and Cultural Affairs no governo Truman, se caracterizou pela luta interna para a continuidade das atividades de informação, justificando sua relevância para o contexto de Guerra Fria, que se formava, e passou de um órgão interino chamado International Information Service (IIS) para o Office of International Information and Cultural Affairs (OIC).

A segunda fase, de 1947 a 1949, sob o comando do Assistant Secretary, George V. Allen - já com algum apoio do governo, mas ainda sem contemplar uma política de informação em todos os seus aspectos (Allen enfatizava o intercâmbio cultural e educacional visando mais o longo prazo do que a propaganda a curto prazo $)^{112}-\mathrm{o}$ Departamento passou a se chamar Office of International Information and Educational Exchange (OIE).

A terceira fase, de 1950 a 1951 - já de consolidação de um programa de informação (com viés de propaganda) no exterior, que tem Edward W. Barrett como Assistant Secretary - é a de lançamento da Campaign for Truth de Truman, quando o Departamento passa a se chamar United States Information and Education Exchange Program (USIE). Essa fase, de consolidação interna da importância de um programa consistente de propaganda anticomunista no exterior, já mostra o compromisso pessoal de Truman para com o tema. Além disso, a mudança do nome para USIE demonstra a volta da estrutura dupla de educação e informação nos moldes estabelecidos por Creel.

111 Será aqui adotada a divisão de fases e caracterizações gerais, feita por Cull (2005, p.22-3).

112 Em Arndt (2005, p.292), Allen afirmava que as atividades culturais de longo prazo, como as bibliotecas americanas no exterior, tinham que existir, mesmo se a "conspiração comunista" não existisse. Para Allen, a principal arma de informação era a educação (nos moldes de Macleish). 
A quarta fase da política de informação do governo Truman, em 1952, após a valorização e estruturação do programa com a USIE, é marcada pelas pressões internas por um Departamento independente do Departamento de Estado em uma agência autônoma. Para isso, criou-se a International Information Administration (IIA, também chamada de USIIA), já com certa autonomia de ação, mas ainda não independente do Departamento de Estado burocraticamente.

Como se vê, portanto, o entusiasmo com um programa de informação no exterior não ocorreu de maneira automática dentro dos

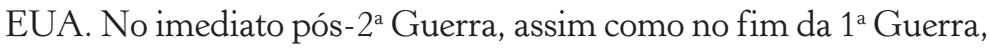
houve uma forte pressão da opinião pública e do Congresso, para o fim dos programas de informação formados durante a Guerra. No entanto, Truman e uma parte da imprensa, além de uma parte minoritária do Congresso viam a necessidade da continuidade e da readequação desses escritórios para a nova realidade que se formava no período. ${ }^{113}$ Havia a necessidade de reajustar o foco, tanto interna quanto externamente, para a batalha ideológica anticomunista que se formara a partir de então.

Em abril de 1945 o Departamento de Estado contratou o professor de Ciência Política da Universidade de Columbia, Dr. Arthur W. Macmahon, para fazer um estudo sobre a readequação dos órgãos de informação no exterior, o qual ficou conhecido como "Macmahon Memorandum”. Após nove meses de pesquisa, ele recomendava que em tempos de guerra o Estado deveria preencher as atividades de informação que não eram feitas pela iniciativa privada. Nos tempos de paz, o setor público não deveria "competir" com o setor privado, e sim readequar os serviços nos postos locais para amplificar as notícias das agências privadas americanas e disponibilizar a essas os discursos e informações oficiais (para produção de programas de rádio e documentários informativos). Para o memorando o serviço nos Estados soviéticos (realizados pelo OWI) deveria continuar em tempos de paz. ${ }^{114}$

$113 \operatorname{Hixson}(1997$, p.4).

114 Documento 33, "Release of Macmahon Memorandum on U.S. International Information Program.". 
Em 31 de agosto de 1945, duas semanas após o armistício com o Japão, as estruturas da $2^{\text {a }}$ Guerra começaram a ser readequadas e Truman determinou o fechamento do OWI, ${ }^{115}$ transferindo algumas de suas funções ao Departamento de Estado, admitindo que "a natureza das relações internacionais contemporâneas torna essencial a manutenção das atividades de informação dos EUA no exterior, como parte integrante de nossa política externa". ${ }^{116} \mathrm{Na}$ mesma ocasião, Truman salientava a necessidade de defesa dos EUA diante dos ataques ideológicos de outros países, refletindo o progressivo Red Scare do período e propôs que os EUA formassem uma política que divulgasse a verdade americana no exterior. ${ }^{117}$

A Executive Order 9608 (Elder, 1968, p.35) também acabou com o Birô e transferiu suas atividades ao mesmo Departamento de Estado, dentro do recém-formado Interim International Information Service ${ }^{118}$ (IIS), sob o comando do publicitário (e futuro senador) William Benton, nomeado Assistant Secretary for Public Affairs, em setembro de 1945, e responsável pela transição das políticas de "informação". Benton defendia que o Departamento de Estado deveria centralizar todas as políticas de informação e começar a considerar as pesquisas de opinião na formulação da política externa, e não só na sua disseminação. ${ }^{119}$

115 Cull (2005, p.22). Truman dissolveu o OWI por meio da Executive Order no. 9608.

116 Segundo Pells, (1997, p.36), Truman transferiu as ações do OWI, entre elas a VOA (diminuindo o volume de suas transmissões) para o Departamento de Estado, sem muito prestígio, até que a Guerra Fria as resssucitasse em importância.

117 Hixson (1997, p.4). O autor também observa que Truman não buscava, ao menos no discurso, calar as informações vindas de outros países, mas dar ao mundo a versão do governo norte-americano dos fatos. E, para isso, novos órgãos de informação deveriam ser criados.

118 Bogart (1995, p.xiii). Até o fim da gestão de Benton, em 1947, o IIS também foi chamado de Office of International Information and Cultural Affairs (OIC).

119 No Documento 19, que contém a transcrição de diálogos sobre política de informação no Congresso, em 1952. 
No mesmo ano, em dezembro, o recém-criado National Security Council (NSC) $)^{120}$ também indicava a necessidade de uma nova coordenação dos órgãos de informação, no âmbito do Departamento de Estado, para fazer frente à propaganda soviética no mundo. ${ }^{121}$ Além disso o National Security Act criou duas novas agências: o Departamento de Defesa e a Central Intelligence Agency (CIA), que incorporou as ações do OSS.

A eficiente experiência da política cultural dos Estados Unidos, na $2^{\text {a }}$ Guerra, influenciou as políticas americanas posteriores, que propunham "um Plano Marshall para o campo das ideias", ${ }^{122}$ como a lei do senador Fulbright, ${ }^{123}$ que autorizava a utilização de recursos excedentes da área militar para financiamento de intercâmbios internacionais. A declaração do Senador ilustrava o pensamento que resumia suas intenções: "A educação é realmente um dos fatores essenciais de nossas relações internacionais - tão importante quanto a diplomacia e o poder militar, nas suas consequências para a guerra e a paz" (Ribeiro, 1989, p.62).

Com a lei de Fulbright para os intercâmbios internacionais, os EUA voltaram a privilegiar, no imediato pós-guerra, as ideias que consideravam a cooperação educacional em longo prazo como saída para o entendimento entre os povos. Além disso, diversas ações culturais e de informação do período de guerra foram deslocadas, desativadas e pulverizadas em diversos órgãos. Porém, no início da década de 1950, a ameaça comunista (e atômica) rondava a cabeça dos políticos e da opinião pública cada vez mais e esforços até então desativados foram retomados com nova roupagem.

120 Criado por meio do National Security Act, reúne os órgãos militares (Marinha, Exército e Força Aérea), com os órgãos de inteligência, como a CIA e orientam o Presidente nas questões de segurança.

121 Haines (1989, p.160) observa que o NSC recomendou a criação de uma vigorosa campanha ideológica para responder à ofensiva ideológica soviética, antiamericana, no mundo.

122 Expressão de Fulbright, citada em Ribeiro (1989, p.62).

123 De agosto de 1946, também comentada por Dizard Jr. (2004, p.148). 


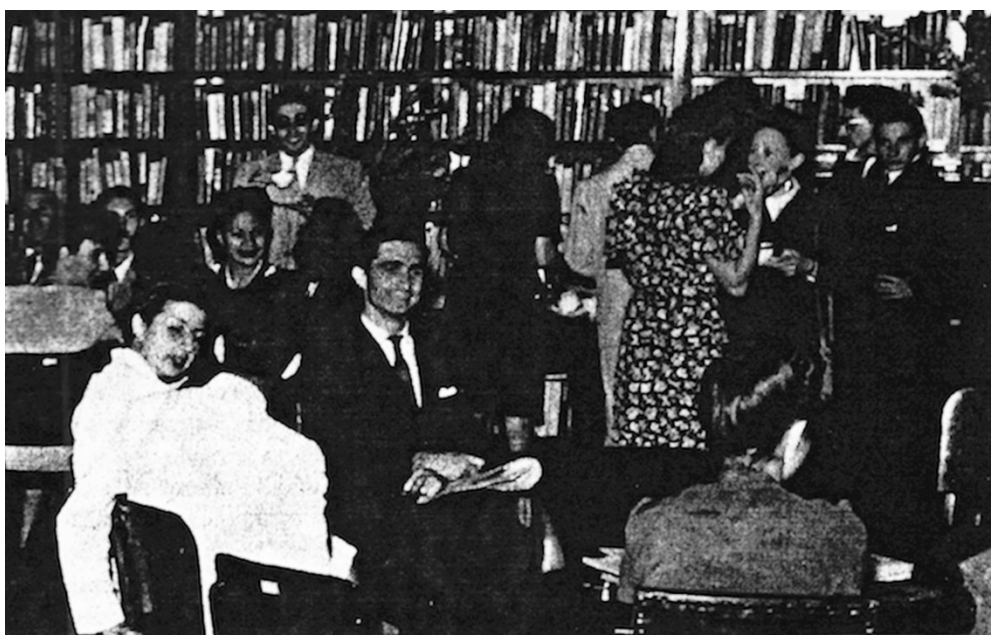

Figura 2 - Chá da tarde em inglês aos sábados, no centro binacional do Rio de Janeiro, em 1947.

O Congresso americano começava a se movimentar e propor ações para políticas culturais e de informação no exterior para fazer frente ao avanço comunista. Em janeiro de 1948, as duas casas do Congresso aprovaram a Smith-Mundt Act (Public Law 402), proposta pelos republicanos Senador H. Alexander Smith, de New Jersey e o Deputado Karl Mundt, de North Dakota (Pells, 1997, p.62, 348; Dizard Jr., 2004, p.148). A lei deu um inédito passo por regulamentar e legitimar, em tempos de paz, ${ }^{124}$ as atividades de informação, de educação, culturais e psy-ops no exterior.

Após a aprovação dos Fulbright e Smith-Mundt Act, o então chamado de Office of International Information and Cultural Affairs (OIC) é transformado em Office of International Information and Education Exchange (OIE), que, segundo o espírito da época, fortaleceria as atividades culturais e educacionais no exterior (em detrimento daquelas em curto prazo, de "informação”). Para o seu

124 Segundo Bogart, (1995, p.xiv), a Smith-Mundt foi um passo fundamental para uma política que promovesse o melhor entendimento entre outros povos e os EUA. 
comando foi nomeado como Assistant Secretary of State for Public Affairs, em março de 1948, o diplomata George V. Allen. ${ }^{125}$

A estrutura do OIE, em março de 1948, tinha só em Nova York 6 escritórios (na rua 45 West, na Broadway, na $5^{\text {a }}$ Avenida, em Wall Street e dois na rua 57 West), com mais de 415 funcionários e diversas atividades (estúdios, laboratórios e arquivos de filmes e setor administrativo). Em abril do mesmo ano, o OIE propunha se expandir ainda mais em NY, com um novo espaço para sediar sua sala de controle principal que monitoraria todas as suas atividades. ${ }^{126}$

Para a sua nova política externa, Truman lançou duas frentes de ação, dando novos nomes e nova roupagem para ações que já estavam

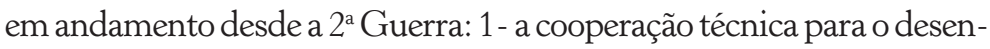
volvimento (respondendo assim também à demanda dos países latino-americanos $)^{127}$ e 2 - uma campanha de "informação", que divulgaria a "verdade" americana aos países do mundo. Para a primeira frente, Truman lançou, em 1949, o Ponto IV. Para a segunda, a "Campaign for truth". Os dois esforços, cooperação e informação, como acontecia antes, e como aconteceria depois, dialogavam entre si e eram parte da mesma estratégia americana para América Latina e para o mundo.

O Ponto IV (Sellers; May; McMillen, 1990, p.367) tinha como objetivo final solapar a ameaça comunista na América Latina e, para isso, usou como instrumentos o estímulo ao desenvolvimento industrial e científico. Em janeiro de 1949, o Presidente Truman citava, em seu discurso de posse, as mesmas recomendações das missões Cooke e Abbink (Haines, 1989, p.118), que propunham o

125 Para Bogart (1995, p.xiii, xiv), o OICE seria o antecessor do Office of Educational Exchange, que no pós-guerra (após a criação da USIA Em 1953) cuidaria exclusivamente do intercâmbio educacional, visando construir uma imagem dos EUA no exterior, em longo prazo. Alguns autores, como Haines, por exemplo, discordam desse perfil dos programas educacionais. Segundo Haines (1989, p.165), mesmo o programa Fulbright se rendia aos interesses imediatos, de curto prazo, da propaganda e da doutrinação dos intercambistas.

126 Documento 21.

127 Segundo Haines (1989, p.32), o Brasil e os outros países latino-americanos demandavam dos EUA ajuda econômica para o desenvolvimento, mais do que proteção contra a ofensiva comunista. 
estímulo ao desenvolvimento econômico de áreas pobres do mundo como formas de fortalecer a democracia nos moldes americanos, em lugares que seriam potenciais focos de alastramento do comunismo.

Os programas de cooperação, inicialmente propostos pelo Executivo, propunham um orçamento mínimo de US\$ 84 milhões de dólares para os primeiros dois anos, ${ }^{128}$ mas o Congresso americano não seguiu o mesmo impulso do Presidente, e para o ano de 1950, só aprovou US\$ 34 milhões para ajuda técnica em todo mundo. Desses, o Brasil recebeu apenas US\$ 5 milhões em cooperação (Haines,1989, p.118).

Segundo o discurso de George V. Allen, Assistant Secretary of State for Public Affairs em 1949, o anúncio do Ponto IV tinha, além de suas intenções altruístas, também motivações "egoístas" que beneficiariam os EUA:

Foi egoísta porque os Estados Unidos faz grande parte de seus negócios com os países mais desenvolvidos economicamente. Foi egoísta porque a economia de "livre iniciativa" pode permanecer mais saudável na expansão mundial econômica. Foi egoísta porque a paz mundial e a segurança dos Estados Unidos dependem do bem estar das nações subdesenvolvidas. ${ }^{129}$

Concluindo seu raciocínio, Allen destacava que a participação de empresas norte-americanas era central para o sucesso do Ponto IV: “... é desejável que as construtoras e empreiteiras americanas participem da maior parte do Programa Ponto Quatro.”. ${ }^{130}$

Para os programas do Ponto IV na América Latina, o OIE contava com dois programas de assistência técnica em diversas áreas como mineração, irrigação, controle de malária, aviação, engenharia mecânica, fornecimento de água e cooperação em engenharia: o Interdepartmental Committee on Scientific and Cultural Cooperation, que contava com 180 técnicos na região, e o Institute of Inter-American

128 Documento 24.

129 Documento 24.

130 Documento 24. 
Affairs, que trabalhava especificamente em programas de segurança alimentar e saúde. ${ }^{131}$

No Brasil, uma das principais ações de cooperação de interesse americano acontecia na área de mineração e mapeamento de minérios estratégicos (atividade que já era desenvolvida, não por acaso, desde 1942), e que descobriu a maior jazida de manganês do ocidente. Segundo Allen, ${ }^{132}$ essa tinha quantidade suficiente para que os EUA se tornassem autossuficientes no mineral, importante para as suas indústrias de ferro e aço.

Além disso, era feita no Brasil a cooperação para o suprimento e tratamento de água em mais de 20 cidades da região amazônica, aplicada pelo Institute of Inter-American Affairs, que levava engenheiros sanitaristas americanos ao Amazonas.

Por fim, os EUA desenvolveram com o Brasil um programa de cooperação exclusivo, levando 20 dos melhores engenheiros aeronáuticos americanos para desenvolver uma escola de engenharia aeronáutica do governo brasileiro. Entre os engenheiros que vieram ao Brasil, são citados o Dr. C.I. Stanton, que tinha sido o responsável pela administração de aviação civil norte-americana e o professor e chefe do Departamento de Aeronáutica do Massachusetts Institute of Technology (MIT), Richard H. Smith.

Segundo Allen, a cooperação técnica norte-americana para o desenvolvimento atingia novas classes que antes não tinham acesso à educação. Segundo ele, a educação nos países em desenvolvimento se restringia a algumas poucas famílias ricas, que tinham repulsa ao trabalho manual: "Em muitos países subdesenvolvidos nós percebemos que a educação foi restrita às famílias ricas, que têm uma repugnância social pelo trabalho manual. Eles não têm aquilo que Harold Lasswell chama de 'dignidade dos uniformes'“. ${ }^{133}$ Indicado para a embaixada na Iugoslávia após o rompimento de Tito com a

131 Documento 24.

132 Documento 24.

133 Documento 24. No original, "dignity of overalls". Tipo de roupa usada por funcionários de trabalhos pesados. Em português também chamado de "macacão". Ou seja, amor pelo trabalho manual. 
URSS, ${ }^{134}$ Allen deixa os Public Affairs, substituído por Edward W. Barrett, ex-diretor do OWI no final da $2^{\text {a }}$ Guerra.

Em um primeiro momento, centrada no Departamento de Estado, a "Campaign for truth" ${ }^{135}$ - renovado programa de informação de Truman - era um primeiro sinal de que os EUA não iriam enfraquecer a sua política ideológica na batalha contra o comunismo em outros países do mundo. Ao longo do governo Truman, cada vez mais as discussões e ações sobre a relevância das operações psicológicas (psy-ops) e de informação se fortaleciam.

Barrett, Assistant Secretary of State for Public Affairs, de 1950 a 1952, deixava claro que cada vez mais a opinião pública de outros países (inclusive de aliados) tornava-se peça-chave para a política externa norte-americana. Segundo Barrett, mesmo quando os EUA precisasse ser mais "duro" com algum outro país, poderia fazer isso sem irritar sua opinião pública. Para ele, a atenção contínua para a opinião pública estrangeira poderia prevenir possíveis desentendimentos, mesmo em casos de crise política com outros países. ${ }^{136}$

Seguindo essa orientação, o USIE, United States Information and Educational Exchange Program, ${ }^{137}$ estabeleceu acordos de cooperação na área de cultura e informação com o governo brasileiro, em 1950. Destacavam-se os acordos bilaterais para criação de institutos culturais binacionais, escritórios de informação, bibliotecas e centros para exibição de filmes, além de bolsas de intercâmbios para

134 Documento 37.

135 Muitos documentos oficiais sobre a Campaign for Truth e o governo Truman estão disponibilizados na internet, disponível em <http://www. trumanlibrary.org/publicpapers/index.php? pid=819\&st=\&st1=> Acesso em: 13 mar. 2014. Sobre a passagem de Truman no Brasil, documentação disponível em <http://www.trumanlibrary.org/publicpapers/index. php? pid=1122\&st=BRAZIL\&st1=> Acesso em: 18 out. 2014. Haines (1989, p.160) destaca o papel central do Departamento de Estado na Campaign for Truth, usando intercâmbios culturais tradicionais (livros, aulas de inglês e intercâmbio de formadores de opinião e acadêmicos) e novos meios de comunicação de massa (produção de programas de rádio, TV, artigos em jornais, revistas e materiais de divulgação específicos para os grupos-alvo).

136 Documento 19.

137 Departamento de Educação e Cultura, então no Departamento de Estado. 
lideranças brasileiras com foco em educadores, jornalistas, artistas e intelectuais, acadêmicos e estudantes (Haines, 1989, p.164).

Esses acordos formalizavam as atividades americanas que já existiam no Brasil e preparava, também institucionalmente, a política de aproximação cultural e ideológica que os Estados Unidos pretendiam estabelecer com a opinião pública brasileira. $\mathrm{O}$ primeiro acordo bilateral cultural entre Brasil e Estados Unidos, ${ }^{138}$ de 17 de outubro de 1950, foi um desdobramento da visita de Dutra aos Estados Unidos, em maio de 1949.

O acordo estabelecia e estimulava que ambos os países criassem centros culturais, postos de informação e centros para exibições de filmes no outro país, aumentassem o intercâmbio de estudantes, artistas, intelectuais, e que realizassem feiras e exposições temáticas. Segundo Maurício Nabuco, embaixador do Brasil nos Estados Unidos: "Esse convênio cultural - o primeiro acordo bilateral, eu acho, a ser concluído pelos EUA - certamente contribuirá para um caminho direto, para um melhor conhecimento, mútuo, dos valores mais arraigados às tradições de brasileiros e americanos". ${ }^{139}$

No mesmo ano de 1950, o USIE também estabeleceu ações conjuntas com a agência nacional brasileira, na produção de programas de rádio, de filmes e materiais anticomunistas, seguindo uma determinação secreta do conselho de defesa brasileiro (Haines, 1989, p.174).

As mudanças no aparato de informação também eram reflexo da mudança das prioridades da política externa norte-americana e da nova configuração de poder mundial no contexto da Guerra Fria, inclusive com mudanças na política americana para a América Latina. Um grande marco dessa mudança se deu a partir do memorando de George Kennan sobre a região ao Departamento de Estado estadunidense, de $1950 .{ }^{140}$

138 Documento 20.

139 Documento 20.

140 “Memorandum by George F. Kennan, FRUS, 1950, 2:615-617”. Mais sobre o memorando, disponível em: <http://www.russilwvong.com/future/kennan/ latinamerica.html> Acesso em: 19 out. 2014. 
Para Kennan, então assessor do Secretário de Estado, após a sua viagem de prospecção à América Latina, em fevereiro e março de 1950, a missão no subcontinente era clara para salvar o hemisfério do comunismo. Mais importante que a democracia na região, que segundo ele já tinha um histórico de pouca tradição democrática, o mais importante era assegurar que o comunismo não se espalhasse, nem que para isso fosse necessário o uso da força.

$\mathrm{O}$ argumento aparentemente contraditório de Kennan sustentava, portanto, que para salvar a América Latina da influência antidemocrática soviética e garantir a estabilidade na região, seria aceitável usar a repressão estatal, local ou não (Haines, 1989, p.19, 30).

É possível perceber, ${ }^{141}$ principalmente a partir de 1951, um esforço do governo Truman (e do Congresso americano) para unificar todos os serviços de informação, sejam eles "abertos" ou não. Em um relatório que destaca as diretrizes presidenciais, em 4 de abril daquele ano, principalmente relativas às responsabilidades do Departamento de Estado, as ações "abertas" (oficiais), ou não (clandestinas), aparecem como parte do repertório das operações "psicológicas":

De acordo com as orientações desta diretriz, operações psicológicas devem incluir todas as atividades que não forem as de tipo "aberto" entre as ações planejadas e executadas, que deverão permanecer e serem mantidas aqui, segundo o estabelecido, (isto é, com o Estado). ${ }^{142}$

A primeira iniciativa presidencial para a unificação dos serviços de informação se deu formalmente em julho de 1951, com a formação do Psychological Strategy Board ${ }^{143}$. Essa propunha unificar todas as ações psicológicas do governo em torno de uma estratégia comum, que articularia as ações do Departamento de Defesa, do Departamento de Estado e da CIA.

141 De acordo com documentação analisada, principalmente Documentos 15 a 19 .

142 Documento 17.

143 Documento 15. 


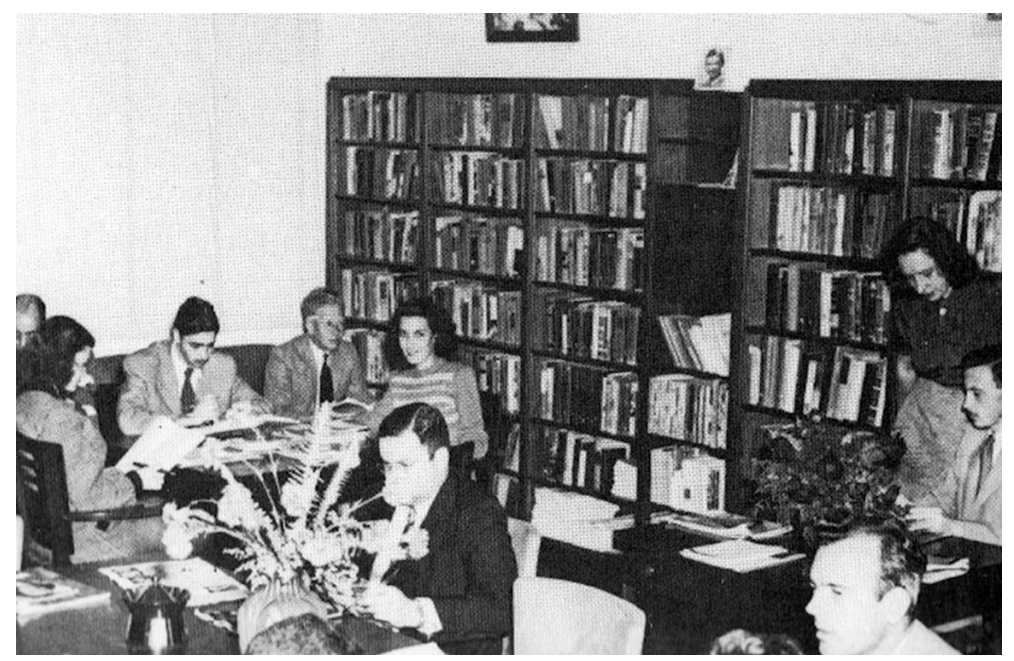

Figura 3 - Enquanto os EUA reestruturavam sua estratégia psicológica no exterior, estudantes liam o melhor que a literatura americana tinha a oferecer no centro binacional de Porto Alegre, em 1951.

De acordo com essa diretriz presidencial, o Psychological Strategy Board (que se reportaria ao National Security Council) seria responsável pela formulação, propagação, avaliação das políticas psicológicas de acordo com os objetivos do país e da coordenação dessas nos diversos Departamentos e agências do governo. ${ }^{144}$

A tentativa de unificação das atividades de informação tinha como por objetivo eliminar a duplicação de esforços, muitas vezes contraditórios, entre Departamento de Estado, Forças Armadas e outras agências do governo, inclusive as responsáveis pela cooperação econômica e técnica internacional, como o Economic Cooperation Administration (ECA), a Mutual Security Agency (MSA) e o Technical Cooperation Administration (TCA); tanto nas ações "de campo”, nos postos locais (USIS e outras representações), bem como na administração, em Washington. ${ }^{145}$

144 Documento 15.

145 O Documento 16 observa a ação conjunta das políticas de informação e de cooperação econômica e técnica. São os ECA (Economic Cooperation 
Ainda segundo orientações presidenciais, o Board, apesar do papel de coordenar as atividades diversas, não tinha o poder de implementar as ações, papel das agências e Departamentos (principalmente o de Estado e o de Defesa $)^{146}$.

A preocupação com o aspecto psicológico e a política externa era tão forte que, além do "Psy Board", que centralizava todas as operações do executivo principalmente em torno do Departamento de Estado, o Legislativo também aventou a possibilidade de criar uma "Central Psychological Agency", em fevereiro de 1952, que responderia diretamente ao Congresso, e não ao Presidente. A proposta, segundo reportagem da época ${ }^{147}$, surgiu durante uma conferência sobre psychological warfare convocada pelos congressistas Orlando K. Armstrong e Charles J. Kersten, e que tinha como participantes muitos dos refugiados do bloco soviético nos EUA.

Em editorial do The Times, de Londres, essa proposta é criticada como uma "RECIPE FOR MUDDLE"148, dizendo que a criação de duas agências destinadas à políticas psicológicas causaria uma confusão de competências e que provocaria a necessidade de uma terceira nova agência, externa, para coordenar essas duas primeiras:

De qualquer maneira, a existência de duas organizações - uma que se reportaria ao secretário de Estado e outra, ao Congresso produziria uma enorme confusão. Sem dúvida seria necessário estabelecer um novo comitê coordenador de guerreiros psiquiátricos. ${ }^{149}$

Administration), o MSA (Mutual Security Agency), TCA (Technical Cooperation Administration), disponível em <http://history.state.gov/historicaldocuments/frus1952-54v01p1/terms > Acesso em: 19 out. 2014. Esses órgãos de cooperação econômica e técnica, antecessores da USAID (só criada em 1961) já agiam em consonância com as ações de informação no exterior, também nos padrões estabelecidos por Creel e ampliados por Rockefeller.

146 O Documento 17 (novembro de 1951) destaca a diferença entre o papel do Board (coordenação e orientação), dos Departamentos de Estado, Defesa e agências (implementação das políticas).

147 Documento 18. Editorial do "The Times".

148 Em uma minha tradução livre, "receita para confusão/trapalhada".

149 "psychiatric warriors", em Documento 18. 
$\mathrm{O}$ artigo, de tom crítico, reprovava também a proposta por não confiar no perfil dos indicados que participariam dessa iniciativa do Congresso. $\mathrm{O}$ argumento justificava que, mesmo não havendo uma carreira própria para os agentes de informação, o Psychological Strategy Board reunia, pelo menos, o melhor quadro de funcionários possível com aqueles que já tinham participado nessas funções durante a $2^{\text {a }}$ Guerra.

O crescente red scare e as sucessivas pressões internas da opinião pública e do Congresso para uma política de propaganda (ou informação) mais consistente por parte do executivo fizeram com que o governo Truman lançasse a sua derradeira cartada, reconhecida como a sua última fase das políticas de psychological warfare.

Em janeiro de 1952, foi criada a International Information Administration (IIA $)^{150}$, a super agência de informação que fortaleceria, unificaria e aperfeiçoaria a implementação da política de propaganda americana. O IIA pode ser considerado o antecessor imediato da USIA em sua estrutura interna e objetivos.

Seguindo a concepção inicial da política externa de Truman e de seu Ponto IV, o IIA, braço de informação do Departamento de Estado (ainda como uma agência "semiautônoma"151), trabalhava em coordenação com as atividades de cooperação técnica do TCA (Technical Cooperation Administration) e com os outros Departamentos do governo (participantes do "Psy Board") 152 .

150 Segundo Bogart (1995, p.xiv), durante o segundo governo Truman e o primeiro Eisenhower, o IIA continuou enfrentando várias pressões externas e mudanças constantes em sua estrutura até a criação da USIA.

151 Documento 23, p.6.

152 Segundo o Documento 23, o IIA também coordenava as ações de informação na Europa com a Mutual Security Agency. Em trecho selecionado em Transcrição 53 (Transcrições). Bogart (1989, p.xiv) comenta a relação de cooperação do IIA com outras agências. Haines (1989, p.161) observa a maneira como o IIA agia como ampla, também pela cooperação com Departamento de Estado e outras agências, e respondendo às crescentes demandas do Congresso. 


\section{PSYCHOLOGICAL OFFENSIVE}
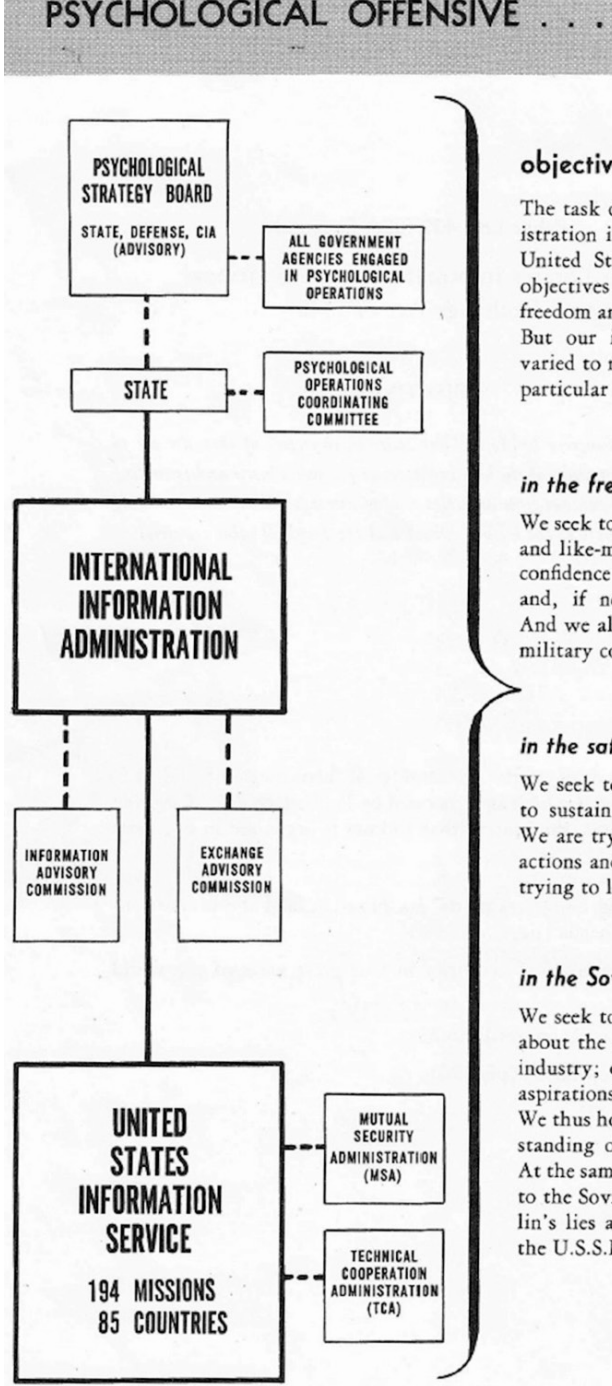

\section{objectives}

The task of the International Information Administration is to promote the foreign policies of the United States. In so doing, we seek the same objectives everywhere in the world-peace and freedom and individual opportunity for all peoples. But our information approaches necessarily are varied to reach the particular interests of people in particular areas.

\section{in the free world}

We seck to build understanding between Americans and like-minded people. We are trying to inspire confidence in the strength of the free world to deter and, if necessary, to resist Soviet communism. And we also are trying to strengthen political and military cooperation among free peoples.

\section{in the sotellite countries}

We seck to encourage the spirit of the people and to sustain their hopes of ultimate independence. We are trying to keep them fully informed of the actions and policies of America. And we are also trying to let them know they are not forgotten.

\section{in the Soviet Union}

We seek to reach the Soviet people with the truth about the American way of life - our farming and industry; our schools, homes, and churches; our aspirations; and our genuine desire for a just peace. We thus hope to develop a morc enlightened understanding of the American people by the Soviets. At the same time, we are trying to give information to the Soviet people that will unmask the Kremlin's lies and distortions about conditions within the U.S.S.R. and about the free world.

Figura 4 - Psychological Offensive: estrutura do IIA.

Agindo inicialmente em 85 países (com 194 postos locaisUSIS $^{153}$ ), a reestruturação feita a partir da criação da IIA objetivava

153 Documento 23, p.6. 
melhor aproveitar os recursos públicos e aprimorar as ações de informação americana no exterior ${ }^{154}$. O objetivo do IIA era quase messiânico: "A intenção é encaminhar os esforços do IIA para onde eles contribuíssem mais e com os maiores resultados para o investimento público, nesta "cruzada de ideias" no exterior". ${ }^{155}$

Comandadas por um Public Affairs Officer (PAO), os USIS variavam de tamanho, contendo desde um até 459 funcionários (como no USIS Japão), abarcando profissionais de imprensa, cinema, bibliotecários, assessores de informação e de cultura, conforme a necessidade local. O número de funcionários do IIA era, por isso, muito maior no exterior do que nos EUA. A proporção em 1952 era de 5 funcionários no exterior para 1 nos EUA.

A figura acima mostra a estrutura organizacional do IIA, tanto em sua relação com a administração em Washington DC (respondendo ao Departamento de Estado e ao "Psy Board"), quanto na sua relação com o "campo", nas diversas representações locais e com as agências de cooperação. Por fim, o organograma do IIA mostra os objetivos gerais, tanto os específicos para países do "mundo livre", como nos países satélites e na União Soviética.

É interessante notar que para garantir a paz e a liberdade no mundo (interessantes à penetração das empresas americanas) e promover a política externa, o IIA se adaptava às diferentes realidades, de acordo com as demandas de cada local, e de acordo com as diretrizes estabelecidas pelos USIS.

Com os países do bloco capitalista a aproximação se daria principalmente pela cooperação política e militar, para aumentar a confiança entre esses e evitar a sua aproximação com o comunismo soviético.

Para os países satélites comunistas, o objetivo americano era fortalecer a esperança de independência em relação ao bloco soviético, divulgando as informações sobre o Ocidente e os EUA e mantendo um canal de relações com esses países.

154 Documento 23, preâmbulo.

155 Documento 23, p.6. 
Para o bloco soviético, a meta era divulgar as maravilhas do "american way of life" e as intenções americanas de paz e desenvolvimento. Ao mesmo tempo, as políticas do IIA nesses países visavam desmentir as informações distorcidas divulgadas pelo Kremlim sobre o mundo capitalista.

A ameaça comunista se delineava claramente para o governo americano e o IIA viria para se contrapor a ela. Para o IIA, de acordo com o gráfico abaixo, desde 1949 as "cortinas de ferro e de bambu", ${ }^{156}$ que abrigavam 800 milhões de pessoas pelo mundo, trabalhavam ideologicamente, construindo uma campanha de "ódio" e minando a confiança dos outros países do mundo contra os americanos, os EUA e sua liderança global.

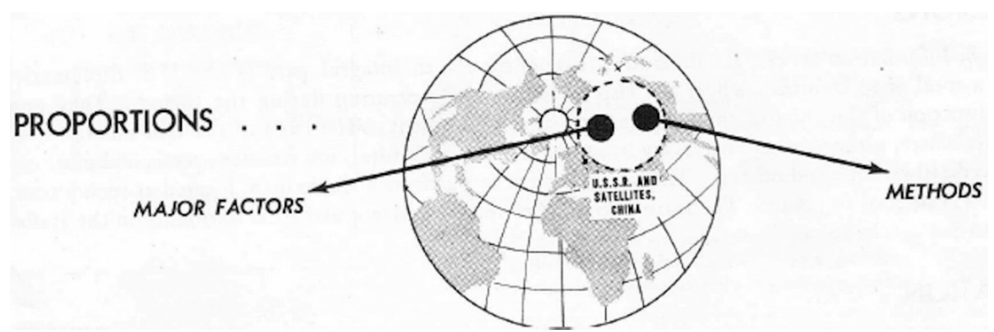

Figura 5 - Expansão da informação soviética pelo mundo.

Ainda, segundo relatórios internos do IIA, ${ }^{157}$ a frente soviética contava com mais de 185 mil estudantes, de mais de 6 mil escolas de propaganda locais, além de 135 mil em 200 escolas regionais e 7 mil em 6 faculdades - todos eles em tempo integral. Segundo a análise estadunidense, em 1952 a frente de batalha ideológica soviética contava com pelo menos 250 mil "propagandistas" em tempo integral, e mais de 3 milhões em dedicação não exclusiva (part-time).

É interessante notar como, nos documentos oficiais americanos, como os funcionários americanos são chamados de agentes de

156 Segundo o Documento 23 (p.5), simbolizavam os blocos russo e chinês, de onde saíam as políticas de informação anti-americanas que caracterizavam a Guerra Fria.

157 Idem, p.5. 
informação e os mesmos profissionais soviéticos são chamados de "propagandistas".

Para os analistas do IIA, ${ }^{158}$ a propaganda era o segundo maior gasto soviético, depois das despesas militares, demandando o equivalente a US\$ 1,5 bilhão de dólares por ano em despesas "diretas", como publicações, intercâmbios de pessoas e programas de rádio ao redor do mundo. Nesses gastos não entravam os outros bilhões gastos com propaganda "indireta" apoiando movimentos grevistas, conflitos trabalhistas e políticos em outros países.

O IIA também repetia uma característica estruturante do modo americano de fazer política de informação desde Creel, tendo as pesquisas de opinião pública ${ }^{159}$ como base para definição de suas ações nos países. Os levantamentos consideravam principalmente as características ideológicas de cada país, os diferentes interesses por região, pensando como as politicas do IIA se adaptariam melhor a cada realidade e como a eficácia dessas poderia ser medida para atingir os públicos-alvo da melhor maneira.

Para essas pesquisas, o IIA mantinha uma equipe própria e também contratava alguns institutos privados e universidades, que continuariam posteriormente a trabalhar com a USIA, como o Institute of Public Opinion Research, a McCann-Erickson, o Gallup, e o Research Center for Human Relations of New York University.

Relatórios internos de $1951^{160}$ mostravam que o IIA recebia cada vez mais cartas dos leitores e ouvintes de seus programas (de 260 mil cartas para 300 mil naquele ano), mas também percebia que seus postos locais (USIS) sofriam cada vez mais ataques dos comunistas. Por isso, o Departamento de Pesquisa aumentava a atenção sobre a mídia no exterior, com centenas de clippings diários de revistas e jornais no exterior, fazendo pesquisa qualitativa com depoimentos de

158 Documento 23, p.5. Segundo Bogart (1995, p.xii) isso era equivalente a $2 \%$ do PIB da URSS, mais de 20 vezes mais do que os EUA gastavam com propaganda no exterior naquela ocasião.

159 Documento 23.

160 Documento 23. 
mais de 2 mil refugiados do bloco soviético e mais de 8 mil ouvintes de programas de rádio produzidos pelo IIA no bloco capitalista.

Além disso, o Departamento de Pesquisa do IIA fazia levantamentos qualitativos específicos de campo, com relatórios semestrais de cada PAO (Public Affairs Officer), relatórios estatísticos sobre as atividades em cada país. Tudo isso cerca de quatro vezes por ano, além das centenas de entrevistas com funcionários que voltavam do campo. ${ }^{161}$ Os estudos qualitativos, voltados para as peculiaridades e diferenças culturais de cada país, tinham objetivo de atingir, da melhor maneira, cada público, além de estudar a ação cultural soviética e seus impactos em cada país. ${ }^{162}$

Fora as ações de pesquisa, o IIA também contratava empresas privadas americanas para a implementação de suas ações culturais. Essas muitas vezes subcontratavam empresas locais para baratear seus custos finais, como por exemplo, grandes corporações de filmes americanas contratadas pelo IIA, que terceirizavam seus serviços para produtoras locais. Algumas empresas foram até criadas para prestar serviço ao IIA (e muitas vezes eram pagas por outros, como organismos não-governamentais), em serviços como tradução e distribuição de livros. ${ }^{163}$

Como mostra o gráfico acima, em 1952, o IIA já contava com 166 parceiros privados, indivíduos e organizações que ajudavam na realização das atividades com a fachada de ações da "sociedade civil”. Pode-se notar que a abrangência das ações do IIA, em 1952, crescia substancialmente: com 194 centros binacionais (como espaços físicos para encontros e com bibliotecas) em 61 países; com 7 mil e 200 intercambistas que visitaram os EUA durante aquele ano; com mais de 200 milhões de publicações distribuídas ao redor do mundo; com transmissão de rádio para mais de 100 países; e atingindo mais de 300 milhões de espectadores com seus filmes, exibidos em salas comerciais, escolas, auditórios e nos lugares mais longínquos.

161 Muitos desses relatórios semestrais, estatísticos quadrimestrais estão disponíveis para consulta no National Archives, em College Park (NARA II).

162 Documento 23.

163 Documento 22. 


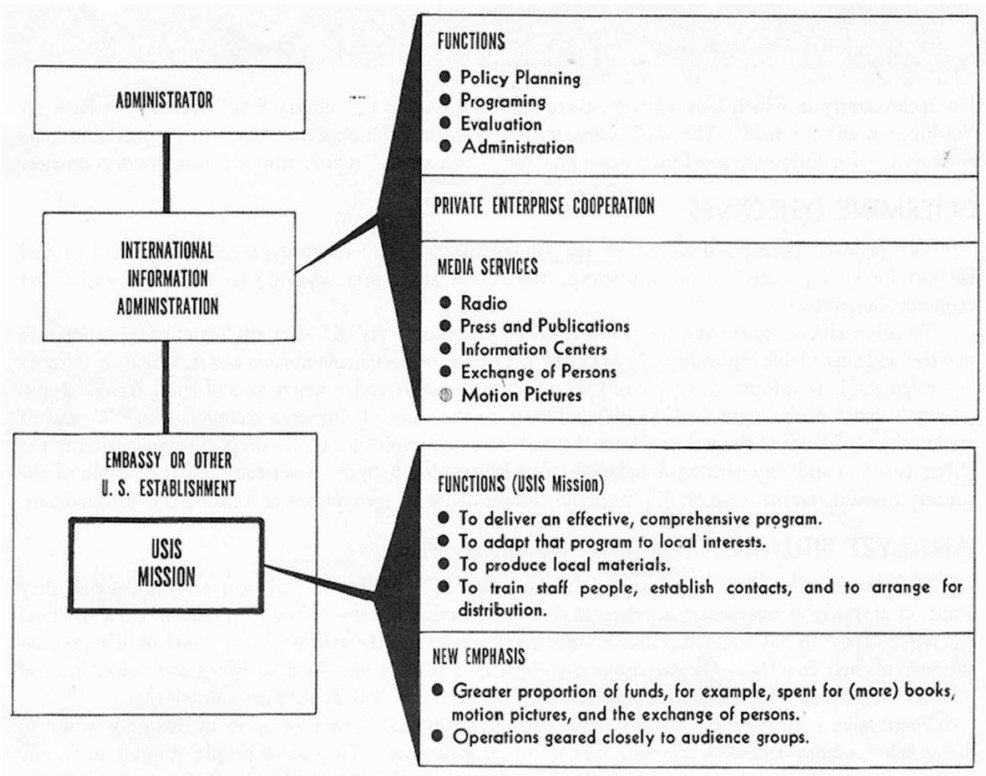

\section{OPERATIONAL STATUS 6/30/52}

\section{RADIO}

Radio broadcasts carried America's message overseas to nearly 100 countries.

\section{PRESS AND PUBLICATIONS}

A daily press file was provided in 85 countries and more than 200 million publications were distributed.

\section{MOTION PICTURES}

Our films last year reached over 300 million viewers, divided about equally between the audience in commercial theaters and that in schools, in halls, and on hillsides.

\section{INFORMATION CENTERS}

194 centers in 61 countries provided a meeting place, as well as a library of American books.

\section{EXCHANGE OF PERSONS}

About 7,200 exchangees came here last year, or went abroad, under U. S. grants. Other thousands, sponsored by private agencies or funds, were assisted.

\section{PRIVATE ENTERPRISE COOPERATION}

Is arranged with 166 American individuals and organizations to undertake supporting (nongovernmental) activities.

\section{USIS MISSIONS-6/30/52}

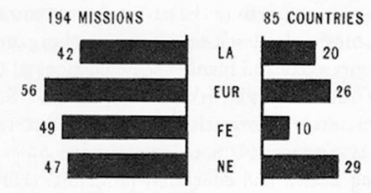

EMPLOYMENT AUTHORIZED-6/30/52

\begin{tabular}{|c|c|c|c|}
\hline 3,228 & 6,242 & & \\
\hline & TOTAL & & \\
\hline DOMESTIC & OVERSEAS & AMERICANS & LOCALS \\
\hline
\end{tabular}

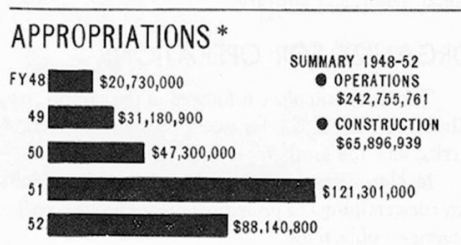

Figura 6 - Gráfico sobre estruturas e atribuições do IIA em 1952. 
Apesar das linhas gerais e objetivos comuns, o IIA também sofisticou os métodos das políticas locais de informação para alcançar o mesmo objetivo em locais diferentes. Para isso, a análise qualitativa de cada realidade local era fundamental para a definição da estrutura local e de seu modo de ação: era o chamado "country plan" (Bogart, 1995, p.59). ${ }^{164}$ A USIA também seguiu os country plans em seus anos de funcionamento, fazendo análises qualitativas periódicas, que direcionavam as ações em cada país.

A pesquisa de mercado, que definia os objetivos de informação americana expressadas em cada country plan, tinha como por meta inicial medir as opiniões políticas de um determinado país sobre suas relações com os EUA, com a União Soviética e em relação a outros países (geralmente seus países vizinhos, ou países satélites).

O plano do IIA para determinado país também levava em consideração os interesses nacionais, os de programas americanos e soviéticos, as atividades não-governamentais e os meios de comunicação disponíveis. Tendo isso em conta, o country plan fazia uma primeira avaliação dos meios de informação disponível no USIS daquele país, como número de funcionários, equipamentos, orçamento, atividades já existentes e grupos-alvos a serem atingidos. Com base nisso, eram produzidos os programas específicos considerando todos os objetivos, as variantes locais e os recursos disponíveis.

Após esses programas atingirem os públicos-alvo era feita uma segunda avaliação, que media a eficácia dos serviços de mídia produzidos pelo IIA localmente, de acordo com pesquisas de opinião pública qualitativa e quantitativa.

O seguinte gráfico dá a ideia de como cada country plan era formado, considerando realidades locais, a presença soviética, particularidades locais, meios disponíveis e duas fases das avaliações: 
•. HOW IT IS DEVELOPED

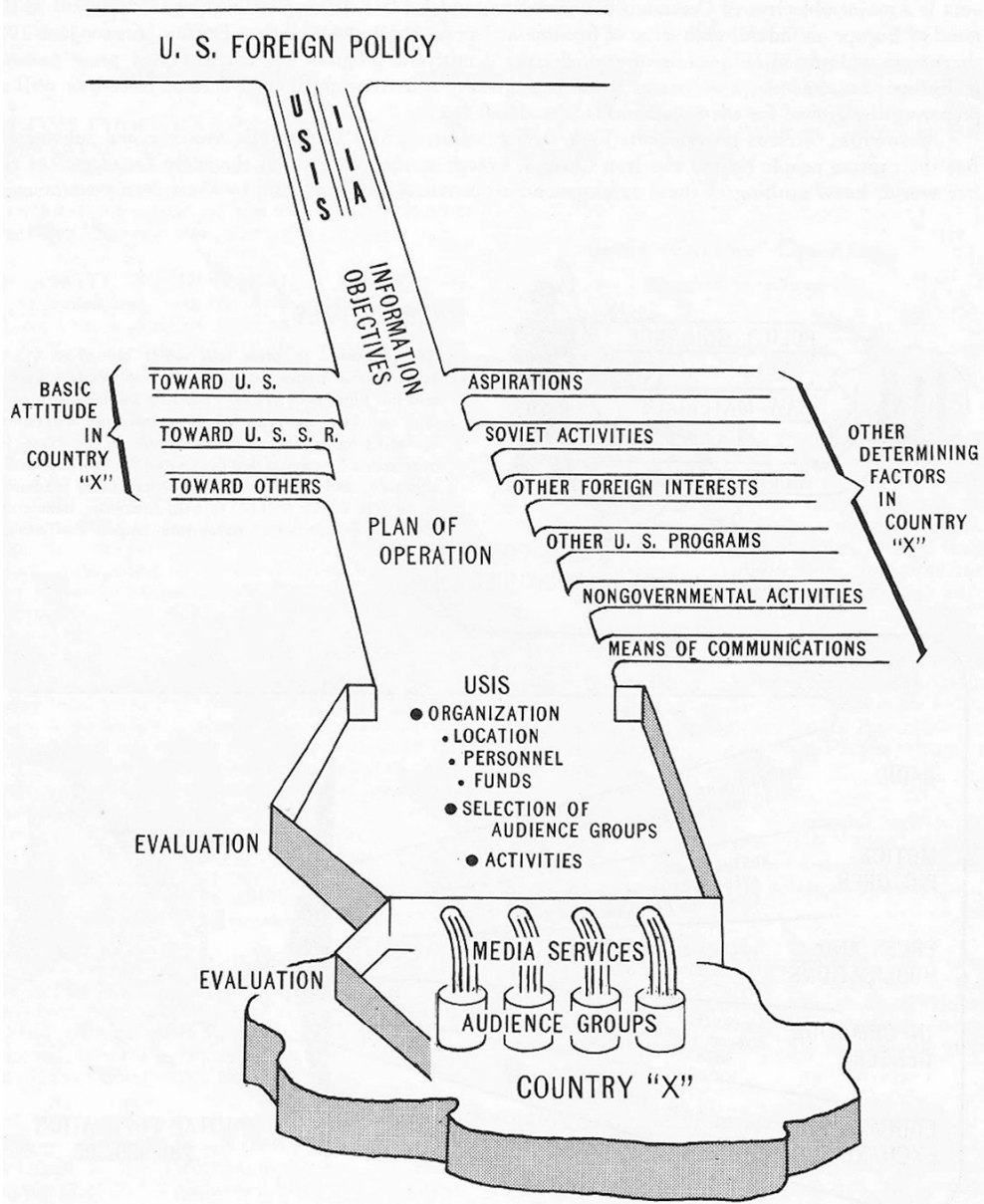

Figura 7 - Country Plan: How it is developed.

A visão do IIA sobre o subcontinente latino-americano, no último ano do governo Truman, era bem definida. Para que se garantisse o princípio comum democrático do continente (nos moldes americanos), os EUA deveriam observar de perto o processo de fortalecimento dos sindicatos e da questão laboral, reflexos do 
desenvolvimento econômico e industrial latino-americano. Essa mudança social poderia provocar possíveis desdobramentos políticos nos países que interessavam aos EUA, particularmente.

Para isso, o diálogo político deveria manter um fluxo de informação constante entre os países latino-americanos e os EUA, mantendo o comando e administração das ações partindo de Washington, para garantir, principalmente, o fornecimento de matérias-primas para os EUA. Como meios seriam usados programas de rádio e cinema, o intercâmbio de personagens relevantes, o trabalho constante com a imprensa e a produção de publicações. Todas essas políticas seriam difundidas pelos 42 USIS e centros binacionais espalhados em 20 países da região.

Durante o ano de 1952, como mostra a Figura 8 a seguir, o IIA produziu e transmitiu na América Latina: mais de 4 horas de rádio diariamente (por meio dos programas do VOA); filmes documentários e jornalísticos para mais de 500 mil pessoas/ano (mais de 1.800 pessoas por semana) e mais de 4 milhões de variadas publicações. Os USIS latino-americanos também contaram com presença semanal de mais de 7 mil pessoas em sete dos centros locais de informação e mais de 350 intercâmbios de lideranças latino-americanas para os EUA.

No caso específico do Brasil, ${ }^{165}$ o IIA se preocupava em atingir os lugares mais afastados do interior usando seus postos móveis, que tinham um acervo de 27 filmes, os quais eram exibidos nas cidades com menos de 44 mil pessoas. Os filmes produzidos pelos USIS do Brasil e que não chegassem às cidades pequenas também eram difundidos por religiosos e igrejas.

O IIA no Brasil não se dedicava, no entanto, somente às pequenas cidades. Para os grandes meios de comunicação de massa eram fornecidas notícias, programas de rádio e filmes documentários produzidos especialmente para o público brasileiro. Cerca de 40\% dos informes de imprensa produzidos pelos USIS do IIA do Brasil, em 1952, eram publicados regularmente por mais de 360 jornais e revistas do país.

165 Documento 23, p.13. 


\section{IIA ACTION: LATIN AMERICA}

The people of these nations represent a powerful force for freedom. In that cause, and for generations, they have shared common ideals, a love of freedom, and the desire to work out their destinies in their own way. A significant development is the growing importance of labor in the affairs of most Latin American countries. Industrialization has been increasing, unions arc growing in membership, and there is a rising vocal demand for better living standards. A more dominant place is being secured by labor, for example, in countries like Argentina, Bolivia, Chile, Colombia, Costa Rica, Cuba, Dominican Republic, El Salvador, Paraguay, and Uruguay.

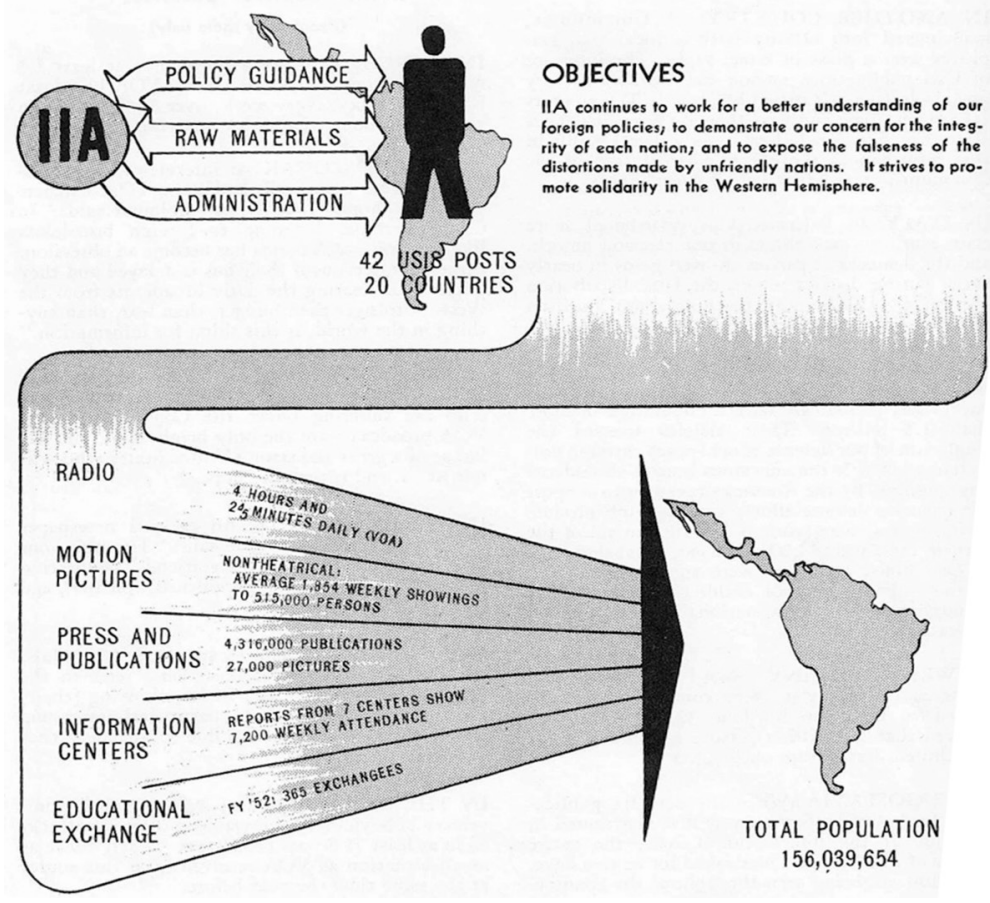

Figura 8-O IIA na América Latina em 1952.

Uma das estrelas dos Usis no Brasil era o radialista Al Neto, ${ }^{166}$ exemplo de programa produzido localmente no Brasil e que seguia a fórmula padrão indicada pelo IIA, tecendo comentários sobre

166 No subcapítulo 3.6, esse tema está desenvolvido a partir das referências documentais e estudos já feitos por estudiosos brasileiros. 
variedades e contra o perigo do comunismo. O VOA na ocasião tinha uma receita para sua programação no exterior: $36 \%$ de notícias, $54 \%$ de comentários e atrações e $10 \%$ de música. ${ }^{167}$

A América Latina era o continente do mundo que tinha o maior número de transmissões de programas de rádio produzidos especificamente para a região (284 "packaged programs"), ${ }^{168}$ transmitidos em ondas curtas a partir dos Estados Unidos e, na maioria das vezes, reproduzidos por emissoras locais.

O IIA também reestruturou a estratégia de publicações e imprensa, descentralizando a produção das notícias e dando maior autonomia para aquelas produzidas pelos postos locais, como um produto de informação local adaptado às características de cada país. Os modelos "pilotos" do formato das notícias eram produzidos nos EUA e depois adaptados aos temas locais. Só no primeiro semestre de 1952 foram produzidos localmente mais de 58 milhões de cópias de 35 panfletos, boletins, histórias em quadrinhos e revistas sobre temas locais. ${ }^{169}$

Além disso, o IIA também funcionava como agência de notícias, transmitindo mais de 8 mil palavras/dia e enviando materiais e fotos também por malote aéreo para mais de 10 mil jornais em 85 países, atingindo, em 1952, uma circulação total de mais de 100 milhões de leitores ao redor do mundo. ${ }^{170}$

A comunicação audiovisual também era uma preocupação do IIA e para isso companhias de cinema privadas eram contratadas e produziam filmes em 42 línguas para 87 países. Naquele ano de 1952, cerca de 466 filmes documentários (newsreels) foram produzidos de acordo com as especificações do IIA e exibidos em salas comerciais de cinema (para mais de 150 milhões de pessoas), salas não comerciais (atingindo também um público de 150

167 Documento 23, p.18.

168 Documento 23, p.18. O continente europeu, em segundo lugar, tinha 71 programas produzidos especificamente para a sua região.

169 Documento 23, p.20.

170 Documento 23, p. 20 . 
milhões de pessoas) e em 342 unidades móveis de projeção ao redor do mundo (65 só na América Latina).

O relatório da IIA ${ }^{171}$ apontava que o público potencial dos filmes produzidos pelo IIA poderia chegar a meio bilhão de pessoas ao redor do mundo, em 1952. Para isso, o IIA disponibilizava 3.704 aparelhos de projeção e 16 centros regionais de manutenção de projetores e filmes. Assim, como a reestruturação na produção de material de imprensa indicava, o IIA também tinha a orientação de estimular a produção local dos seus filmes, adaptando os temas de acordo com as especificidades de cada região.

Ao mesmo tempo, o IIA não descuidava dos programas de intercâmbio de pessoas, levando muito mais pessoas aos Estados Unidos para aprender (em 1952, das 5.614 pessoas, que foram, 2.850 eram estudantes), ${ }^{172}$ do que americanos para fora (1.622, sendo 763 estudantes). Ou seja, o número de americanos que ia para fora aprender era quase 4 vez menor do que os estudantes estrangeiros que iam para os EUA.

Outra característica do programa de intercâmbio do IIA era a ênfase em levar aos EUA lideranças locais, muitas vezes em programas de 3 a 4 meses, de acordo com o perfil do intercambista, seguindo a tradição iniciada também com o CPI e continuada com o Birô. Em 1952 foram 1.768 pessoas, de 65 países, que visitaram os EUA nessas condições, enquanto que em contrapartida somente 201 lideranças americanas foram para o exterior.

É interessante notar que estruturas ligadas à recém-criada ONU faziam parte das estatísticas do programa de intercâmbio do IIA. Naquele ano de 1952, cerca de 338 pessoas ligadas a programas da ONU para o desenvolvimento econômico, administração pública e bem estar social foram selecionadas como intercambistas pelo IIA. Também faziam parte do programa do IIA, 51 agências e universidades privadas e públicas, como o Institute of International Education (também associado à ONU), e o programa Fulbright.

171 Documento 23, p.21.

172 Documento 23: "Exchange of Persons". 
O foco principal dos programas de intercâmbio eram líderes e especialistas dos países ( $80 \%$ dos chamados eram dos campos sindicais/trabalho, funcionários de comunicação de massa/imprensa, rádio e filmes, da área da educação, e do meio político/governamental), juventude, professores/formadores de opinião e intelectuais.

O IIA também se preparou para atingir um maior número de pessoas diretamente, por meio dos 194 centros de informação (em 61 países) e 34 centros binacionais (em 22 países), com um esforço conjunto de tradução de clássicos americanos que eram disponibilizados nas bibliotecas e livrarias (mais de 1,2 milhão de livros publicados em 20 línguas) e no ensino de inglês aos frequentadores dos centros. Na América Latina, o crescimento foi notável só no primeiro ano da década de 1950: 15\% de matrículas nos cursos de inglês; $21 \%$ entre os usuários das bibliotecas, $31 \%$ na presença em eventos culturais dos centros e $61 \%$ de aumento da contribuição financeira local. ${ }^{173}$

$\mathrm{Na}$ ocasião Howland Sargeant, Deputy Assistant Secretary of State for Public Affairs definia os centros de informação como um arsenal de ideias democráticas que se espalhavam pelos países: "Eu sempre penso nestes centros como arsenais de ideias, de amantes da liberdade e indivíduos democratas em muitos desses países. No ano passado estes centros registraram mais de 2 milhões de visitas de pessoas em outros países". ${ }^{174}$

Para garantir a publicação de livros americanos, foi criada, em junho de 1952, uma organização não governamental chamada Book Publishing Corporation, responsável por publicar e distribuir livros com preços muito baixos no exterior. Usando fundos públicos e privados, o aporte inicial para o início de seu funcionamento foi de US\$ 500 mil dólares. Apesar de formalmente independente, a corporação trabalhava em consonância com o Departamento de Estado. ${ }^{175}$

Além de organizações não governamentais, o IIA também contava com a ajuda de empresas privadas, comitês e fundações, que a

173 Documento 23: "Special Programs".

174 Documento 14.

175 Documento 23: "Information Centers". 
partir do envolvimento assumido em alguns dos escritórios americanos do IIA (naquela ocasião, em Washington DC, Chicago, São Francisco e Nova York), agiam no exterior com recursos próprios. Até 1952, mais de 600 compromissos foram assumidos com 102 empresas, 19 organizações não governamentais, 10 fundações e 35 outras organizações americanas no exterior. O cuidado maior era não deixar nenhuma marca de relação com o governo americano quando a ação era realizada no estrangeiro:

Uma atenção maior foi dada a ações independentes, desenvolvidas por organizações privadas com parceiros associados no exterior, e sem o uso das instalações dos USIS. Elas foram estimuladas a complementar as atividades regulares e a formar projetos paralelos, tanto aqueles em que o IIA não está suficientemente equipado para realizar, quanto aqueles que necessitam da não-identificação com as atividades governamentais de informação para serem mais eficazes. ${ }^{176}$

Todas essas frentes de trabalho do IIA fortaleceram os caminhos que iriam ser continuados pela USIA a partir do governo Eisenhower. Apesar da atenção especial dada à Europa, o Brasil seguiu com sua importância estratégica, em virtude do tamanho de seu mercado e das suas potencialidades como fornecedor de matérias-primas. Assim, o País se estabelece como ponto focal da América Latina para as administrações de Truman e Eisenhower. ${ }^{177}$

Ainda impulsionado pelo idealismo que justificou as ações que derrubaram o nazismo na $2^{\text {a }}$ Guerra, os governos do imediato pós-guerra seguiam com uma forte motivação moral que aos poucos

176 Documento 23, p.26, 29. Entre as empresas eram citadas a Sears, a Swift, a General Electric, a Wilson, o New York Times, a McCann-Erickson, a United Fruit, o Reader's Digest, a Shell, a Philco e a Kodak.

177 Haines (1989, p.ix) observa que nas duas administrações não eram muito bem vistas as políticas estatais de controle da economia do Brasil, principalmente em relação aos seus bens naturais, como minerais e petróleo. Além disso, no começo da Guerra Fria, o Brasil tinha importância central para direcionar a América Latina contra a ameaça comunista. 
eram transformadas no esforço ideológico anticomunista. ${ }^{178}$ Ao mesmo tempo, o clima do pós-guerra também impulsionou os discursos nacionalistas e de libertação nos países em desenvolvimento (como nas ex-colônias africanas e asiáticas), com reflexo político nos países latino-americanos.

O desafio americano era continuar seu projeto de influência sem se chocar com os movimentos nacionalistas. Diante dessa conjuntura, o relatório interno do IIA, nos últimos meses do governo Truman, apontava para o desafio a ser seguido adiante, isto é, o de sofisticar a estratégia de influência americana por outros meios que não só os tradicionais militar e econômico: "o delicado novo nacionalismo de muitos países provocará muitos obstáculos para, se não frustrar, dificultar as ações normais dos EUA na condução de negociações diplomáticas, nos ganhos econômicos e na assistência militar". ${ }^{179}$

\section{Macarthismo, Eisenhower e a formação da USIA: people-to-people program}

Nossas representações de informação no exterior nunca tiveram maior reponsabilidade do que agora. A representação deve apresentar ao mundo as políticas e objetivos dos EUA, de maneira clara e factual. Para nós, o necessário é ter políticas claras, dedicadas aos objetivos da paz universal, liberdade e progresso. Essas políticas têm que ser conhecidas e entendidas por todos os povos ao redor do mundo. Essa é a responsabilidade da nova United States Information Agency. ${ }^{180}$

Presidente Dwight D. Eisenhower, 30 de julho de 1953

178 Bogart (1995, p.xvi) destaca que a retórica política do pós-guerra, que trazia elementos da 2a Guerra, eram carregadas de termos como "liberdade", "democracia" e "mundo livre".

179 Documento 23, 1952, p.27.

180 Documento 31. Trecho do discurso proferido por Eisenhower na cerimônia de nomeação do primeiro diretor da USIA, Theodore C. Streitbert. 
Ao mesmo tempo em que a paranoia anticomunista promoveu externamente a readequação das políticas de informação no pós-2a Guerra para o combate ideológico, por outro lado, provocou uma caça às bruxas internamente. $\mathrm{O}$ maior representante do terror anticomunista dentro dos EUA, durante os anos 1950, foi o senador republicano por Winsconsin Joseph McCarthy. ${ }^{181}$

Ao mesmo tempo em que o IIA de Truman organizava a política de informação no exterior, McCarthy, no legislativo, liderava a oposição às políticas de informação no exterior, acusando o Executivo (principalmente o Departamento de Estado e o VOA) de financiar funcionários e livros comunistas no exterior. Entre outras coisas, McCarthy denunciava cerca de 30 mil livros e 418 autores supostamente comunistas, presentes nas estantes das 230 bibliotecas americanas ao redor do mundo, que contavam com cerca de 27 milhões de usuários por ano. ${ }^{182}$

Nas bibliotecas do IIA no Brasil, por exemplo, foram banidos pela embaixada americana no Rio de Janeiro livros considerados "antiamericanos" como Secret history of the Korean war (de I.F. Stone), Paul Robeson, citizen of the world (de Shirley Graham) e The american e Patrick Henry and the Frigate's Keel (de Howard Fast). Até Gilberto Freyre foi temporariamente retirado das bibliotecas americanas no Brasil por ser considerado um autor com inclinações subversivas. ${ }^{183}$

Como parte das investigações promovidas por McCarthy no Senado, o próprio deputy director do IIA, Reed Harris, foi apontado como subversivo, por ter participado de movimentos estudantis, nos anos 1920 e 1930, durante a Grande Depressão, na Universidade de Columbia, onde estudava. O comitê de McCarthy no Senado

181 Documento 33, "Senator McCarthy's investigation of IIA personnel-Compton E Johnson victims" e "Purposes of McCarthy investigations - personal publicity E' jobs for republicans".

182 Documento 30.

183 Sobre os livros retirados pela embaixada americana no Brasil, ver Haines (1989, p.167). 
recomendava que para o IIA fossem indicadas pessoas como "ilibada reputação anticomunista". ${ }^{184}$

É claro que as ações anticomunistas de McCarthy tinham reflexo nos embates políticos entre republicanos e democratas no interior dos programas de informação. Em relatórios internos isso foi diagnosticado:

[A investigação de McCarthy]... foi realizada para fazer propaganda pessoal do Senador McCarthy e também, provavelmente, para fazer o máximo de "Democratas" (McCarthy diria "incompetentes e subversivos") deixarem seus altos cargos no governo, abrindo espaço para outras indicações. Ele foi bem sucedido em ambos objetivos. ${ }^{185}$

Nesse contexto, considerando as eleições presidenciais de 1952, crescia a demanda interna por um comandante de pulso firme que fosse capaz de varrer a ameaça vermelha dos EUA e do mundo. Esse espírito foi traduzido na eleição do republicano Dwight D. Eisenhower, general herói da $2^{\text {a }}$ Guerra, símbolo de seriedade, experiência e defensor primeiro da causa anticomunista americana. ${ }^{186}$

No auge da campanha, Eisenhower tinha se comprometido em usar o programa de informação americano com maior eficiência e regularidade, como uma "arma psicológica" no exterior. ${ }^{187}$ Doze dias após a sua posse, em seu primeiro discurso ao Congresso no State of the Union, em 1953, ele reafirmava esse compromisso:

184 Bogart (1995, p.xv). Reed, ex-funcionário do OWI durante a 2 ${ }^{\mathrm{a}}$ Guerra voltou às atividades de informação durante a administração de Murrow (notório critico do macarthismo) na USIA.

185 Documento 33.

186 Para May; Mcmillen (1990, p.392), Eisenhower se apresentava durante a campanha como um republicano moderado: conservador no que se refere à política econômica, e "liberal"(no sentido americano) no que se refere às políticas sociais. Segundo os autores, a política de Eisenhower durante seu mandato partiu da direita e, ao longo dos anos, foi em direção ao centro.

187 Documento 35. 
Nós temos que garantir que todas as atividades relacionadas à informação internacional sejam mais eficazes, em um esforço unificado e dinâmico em todo esse campo, essencial à segurança dos Estados Unidos e de outros povos na comunidade das nações livres. ${ }^{188}$

Para pensar especificamente a política de informação, o Presidente começou a preparar um time de especialistas de sua confiança, para cumprir a sua promessa à sua maneira. Por isso ele se cercou de dois grupos, criando Comitês que estudariam, discutiriam e proporiam as melhores formas de desenvolver as atividades de informação do governo no exterior.

Para o primeiro Comitê, formado em 26 de janeiro de 1953, o "President's Committee on Foreign Information Activities", Eisenhower indicou como responsável ${ }^{189}$ William H. Jackson, advogado de Princeton e ex-deputy director da CIA, o qual sintetizaria as políticas e atividades de informação relacionadas às relações internacionais e à segurança nacional. Segundo as diretrizes de Ike, o comitê tinha até 30 de junho para indicar as suas recomendações em um relatório final, e seria extinto não mais do que 30 dias depois de feita essa tarefa. ${ }^{190}$ Criou-se também o "President's Advisory Committee on Organization of the Executive Branch", comandado por Nelson A. Rockefeller, chamado informalmente entre os envolvidos em suas ações de "Rockefeller Committee", ${ }^{191}$ que ficou responsável pela reconfiguração de todo o poder executivo. A ideia da nomeação de Rockefeller não era somente voltada para as políticas de informação (uma das grandes habilidades de Nelson), mas uma reforma em

188 Documento 38.

189 Documento 37. Hixson (1997, p.24).

190 Documento 33.

191 Documento 32. Colby; Dennett (1996, p.291); Haines (1989. p.161). Segundo a descrição dos arquivos pessoais de Rockefeller para esse período, (subséries "Special Committee on Government Organization (SCOGO)", "Reorganization Advisory Committee (RAC)", "President's Advisory Committee on Government Organization (PACGO)) Nelson Rockefeller já havia participado em estudos de reorganização do governo em grupos formados pela Universidade de Temple e pela comissão Hoover, criada no governo Truman. 
todas as áreas de governo, seguindo a ótica da dita eficiência administrativa do setor privado. ${ }^{192}$

Como determinado, as ações dos dois comitês foram rápidas, pois também haviam começado antes mesmo de serem criadas formalmente por Eisenhower (as ideias vinham de antes e estavam já em reunião desde, pelo menos, dezembro de 1952). O novo secretário de Estado, John Foster Dulles, mesmo por causa da oposição que o seu Departamento encontrava no Congresso, principalmente pelas mãos de McCarthy, ${ }^{193}$ estava decidido a se livrar de tarefas operacionais mais problemáticas (como as de informação, cooperação, intercâmbio educacional), para se dedicar exclusivamente à política externa. E de certa forma os dois comitês seguiram, mais cedo ou mais tarde, nesse sentido (Reich, 1996, p.503). ${ }^{194}$

O Jackson committee, que consultou mais de 250 pessoas envolvidas com as atividades de informação, oficiais ou não (covert operations), recomendava que as atividades "psicológicas" tinham o mesmo nível de importância das militares, econômicas e políticas, e que o objetivo da política externa americana era a dominação mundial: "[A política dos EUA deve] partir do pressuposto que o objetivo dos governantes da sociedade é a dominação mundial" (Hixson, 1997, p.24). Jackson também indicava que fosse estabelecida uma agência de informação autônoma e que todas as atividades relacionadas à "propaganda" do governo, fossem coordenadas pelo novo Operations Coordinating Board ${ }^{195}$ e não mais pelo Psychological Strategy Board, abolido após a recomendação do novo Coordinating Board (Bogart, 1995, p.xiii).

192 Segundo Colby; Dennett, (1996, p.292), a proposta de Rockefeller queria transformar o Estado americano em um Estado moderno e corporativo.

193 O Documento 37 destaca que quando da proposta de reorganização do Departamento de Estado feita por Eisenhower, McCarthy conduzia pesadas investigações, chefiando o Government Operations Committee no Congresso.

194 Também em Documento 32.

195 Documento 32. 
O comitê de Rockefeller, que emitiu seu relatório ${ }^{196}$ três meses antes do de Jackson (em abril de 1953) partia do princípio que a segurança e o bem-estar da nação dependiam da política externa bem sucedida nos planos político, militar, econômico e psicológico. Para isso, propunha a criação de uma agência independente que respondesse diretamente ao Presidente, e que seguisse as diretrizes da política externa desenhada pelo Departamento de Estado.

Seguindo as sugestões de Rockefeller, a nova agência também seria responsável pela produção e divulgação do programa Voice of America (VOA). A administração da nova agência teria sede central nos Estados Unidos, mas seria gerida de acordo com as administrações locais, em cada representação diplomática americana no exterior (consulados e embaixadas), tendo os embaixadores em cada país como chefes locais, que se reportariam a Washington.

Em correspondência interna, o Presidente Eisenhower reconhecia nas propostas do comitê Rockefeller a saída para a uma eficiente política de informação norte-americana:

Esse relatório propõe, entre outras coisas, a retirada do IIA do Departamento de Estado e no seu estabelecimento como uma agência subordinada ao Poder Executivo, com os devidos arranjos para relação com o Departamento de Estado e outros órgãos do governo. [...] Ao nosso ver, de acordo com uma observação atenta desde 1948, o programa de informação não alcançará sucesso sem que essas mudanças forem feitas. ${ }^{197}$

Por pressão dos senadores Fulbright e Karl Mundt, ${ }^{198}$ as atividades de intercâmbio educacionais se mantiveram sob o Departamento de Estado, após um pedido formal do Comitê de Relações Exteriores do Senado ao Presidente, com exceção do programa de

196 Documento 39.

197 Documento 40. No Documento 35, em ata interna de reunião sobre o relatório Rockefeller, há o registro que "O Presidente, então, disse achar que o memorando estava de acordo com as linhas que ele havia pensado" (tradução nossa).

198 Documento 34. 
intercâmbio de pessoas no exterior - lideranças locais, por exemplo, que ficaria na nova agência. ${ }^{199}$

Para os senadores, assegurar que o intercâmbio educacional ficasse longe da nova agência era manter intacta uma relação "desinteressada” dos EUA com o exterior. Com isso, o relatório Rockefeller sofreu essa ressalva e foi transformado em proposta presidencial ao Congresso no dia $1^{\circ}$ de junho. Após não sofrer nenhum reparo da casa legislativa, entrou em vigor em $1^{\circ}$ de agosto de 1953 como o Reorganization Plan number 8.

Rockefeller, como chefe do comitê de reorganização do executivo, propôs 13 planos de reorganização e 10 deles foram aprovados pelo Congresso. Além de reestruturar o Departamento de Defesa, ${ }^{200}$ Rockefeller separou algumas das atribuições que antes eram pensadas conjuntamente (como ajuda econômica e informação), de acordo

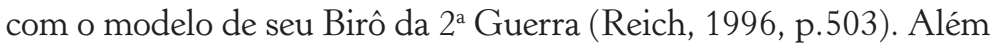
disso, propôs duas agências separadas: a USIA, com as atividades de informação anteriormente exercidas pelo Departamento de Estado e o VOA; e a Foreign Economic Operations Agency, depois chamada de Foreign Operations Administration (FOA), responsável pelos programas de cooperação e assistência econômica a outros países. Isso era estratégico para dirigir e fomentar áreas de interesse americano, além de abastecer os EUA com produtos estratégicos de outros países. Essa também abarcou os serviços de cooperação técnica do Technical Cooperation Agency (TCA), inclusive nos programas de cooperação com agências da ONU, no trabalho de apoio a refugiados, de acordo com as diretrizes do Departamento de Estado (enquanto a USIA assumiu as atividades de informação do TCA e do MSA).

Além de reestruturar os serviços de informação e ajuda dentro do executivo americano, Rockefeller centralizou o processo decisório do Export-Import Bank, visando uma maior liberdade para

199 Documento 32. A separação entre os serviços de informação e o intercâmbio educacional também é descrita em Hixson (1997, p.26).

200 Em descrição das subseries do Rockefeller Archives Center (SCOGO, RAC e PACGO). 
financiar projetos do Terceiro Mundo, de acordo com os interesses americanos.

Por fim, Rockefeller criou um super ministério, assumido por ele mesmo, fundindo a Mutual Security Agency (MSA) e seu orçamento de 4,6 bilhões de dólares, com antigos Departamentos federais responsáveis pelas políticas de saúde, de educação e de bem-estar social: o Department of Health, Education and Welfare (HEW). Como secretário do HEW, Rockefeller promoveu estudos de "controle da mente" (Colby; Dennett, 1996, p.292), dialogando com as atividades de informação da USIA e da CIA.

Ao mesmo tempo em que as propostas de reformulação interna - do executivo em geral, e de informação, em particular - eram aprovadas, Eisenhower começava a se atualizar sobre a situação internacional. Para isso, começou a enviar emissários de sua confiança a regiões estratégicas que viviam instabilidades políticas. Na ocasião, o National Security Council definia como seis países prioritários, nessa ordem: Brasil, Chile, Bolívia, México, Guatemala e Argentina, por causa dos processos de nacionalismos crescentes e perigo de importação de marxismos (Cull, 2008, p.120).

Prioridade entre os países latino-americanos, o Brasil de Vargas era a preocupação dos EUA, principalmente pelo aspecto de "crescente nacionalismo" e também pelas conflituosas relações políticas e econômicas internas (Haines, 1989, p.18).

A notícia "Brother Milton to Make Good-Will Pan Am Tour", de 12 de abril de 1953, mostrava uma foto de Nelson Rockefeller e Milton Eisenhower saindo, sorridentes, do gabinete do Presidente Ike. A imagem retrata o momento depois de uma reunião que definia a visita latino-americana de Milton, ex-funcionário de informação e irmão do Presidente, como uma missão de boa vontade para com os povos pan-americanos, mas no corpo do texto deixava escapar a intenção de prospecção política dada à Milton: O Presidente Eisenhower anunciou hoje que vai enviar seu irmão Milton em uma turnê para o reconhecimento das realidades latino-americanas. ${ }^{201}$

201 Documento 41. 
$\mathrm{Na}$ sua volta pelo giro latino-americano, a preocupação maior de Milton foi avaliar a efetividade dos programas de informação até então. Pelos seus relatos à USIA e até mesmo em entrevistas à imprensa, ele valorizou a eficácia do serviço desempenhado pelos institutos culturais, centros binacionais e intercâmbios de estudantes, professores e trabalhadores, e reconheceu a eficácia dos serviços de rádio e imprensa nos locais.

No entanto, para ele o VOA era ponto inexistente entre as atividades de informação, imaginando até que esse serviço não existisse mais, por causa da sua falta de repercussão. Em carta de 8 de agosto de 1953, para o primeiro diretor recém empossado da USIA, Theodore Streitbert, Milton reportava:

Eu voltei da América do Sul para casa, muito entusiasmado sobre os institutos culturais, os centros binacionais, os programas de intercâmbio de estudantes, professores, trabalhadores e todas as atividades correlatas. As partes de imprensa e rádio do programa de informação me pareceram eficazes. Eu não obtive uma reação confiável sobre o Voice of America. Para dizer a verdade, eu não perguntei sobre isso na América do Sul, e ninguém falou voluntariamente. Pode ser até que não estejam sendo enviadas transmissões diretas de rádio para América do Sul. ${ }^{202}$

Pelo que se vê nos documentos, Milton Eisenhower, na época Presidente do Pennsylvania State College, manteve contato permanente com a USIA, em frequentes diálogos telefônicos. Em outra carta do mesmo período ${ }^{203}$, de Streitbert a Milton, o diretor da USIA solicitava uma indicação para nomear o responsável pelas bibliotecas e da produção de livros da USIA, o que foi feito pelo irmão do Presidente Eisenhower.

Na mesma ocasião (a partir do momento pós-eleição, nos últimos dias de 1952 e nos primeiros meses de 1953), Ike também confiou a 
dois dos homens mais ricos do país, a missão de visitar o Brasil e falar pessoalmente com Vargas. Não coincidentemente eles eram seus ministros mais importantes: o magnata do petróleo Nelson Rockefeller (Secretary of Health, Education and Welfare) e aquele do manganês, George Humphrey (Secretary of Treasure).

Segundo Bandeira (1973, p.276), Humphrey não voltou muito satisfeito de sua visita ao Brasil. Rockefeller, por sua vez, vinha com a missão de retomar as boas relações de Vargas com os EUA, agora com o Presidente Eisenhower. A conjuntura porém era outra.

Rockefeller, um dos principais acionistas da Standard Oil, não à toa, chegara no momento em que o Presidente e Congresso brasileiros discutiam o modelo a ser definido para a exploração do petróleo no Brasil. Apesar da boa relação anterior entre Nelson e o Presidente brasileiro, pelo relato apresentado ao Secretário de Estado, John Foster Dulles, em 22 de dezembro de 1952, Vargas é caracterizado por Nelson como um típico caudilho latino-americano, um ditador que define suas políticas influenciado pelo seu humor e relações pessoais:

Caro Foster, como você provavelmente sabe, o Presidente do Brasil Getúlio Vargas é um homem que age motivado pelas relações pessoais; de certo modo pode-se dizer que ele é do tipo do velho "caudilho". Ele foi um ditador por 17 anos, foi deposto e depois eleito Presidente do Brasil em 1950. ${ }^{204}$

O relato de Rockefeller descrevia que, na ocasião da $2^{a}$ Guerra, as relações pessoais com o Presidente Roosevelt eram tão importantes para Vargas que, mesmo com a grande influência nazista, o Brasil decidiu se envolver definitivamente do lado dos EUA:

O fator importante para conseguir a cooperação do Brasil durante a última guerra, mesmo com a forte influência nazista, foi a relação pessoal próxima que o Presidente Roosevelt mantinha com ele. 
Ele manteve uma correspondência pessoal com o Presidente Vargas, e consequentemente o Presidente Vargas cooperou inteiramente em assuntos importantes, de bases aéreas na costa ${ }^{205}$ até o envio de divisões brasileiras para a Europa. ${ }^{206}$

Como resultado da visita de Rockefeller encomendada por Ike, Nelson apontava uma receita para salvar a boa relação entre os países no pós-Guerra. Para garantir que o Brasil de Vargas fosse alinhado aos EUA, seria necessário o contato permanente do Presidente Eisenhower e seu esforço pessoal em agradar Vargas: "Eu ouvi de contatos pessoais, que o Presidente Vargas gostaria muito se um contato direto, semelhante, fosse construído com o General Eisenhower" ${ }^{207}$

Vargas ainda deixou o recado a Rockefeller de que não daria o primeiro passo nessa aproximação pessoal que pudesse se construir com o novo Presidente americano. Mas se esse fosse tomado por Eisenhower, isso poderia significar uma mudança qualitativa na relação entre os países e na nova configuração que se formava no bloco ocidental:

No entanto, ele não acha apropriado tomar a iniciativa. Do que eu conheço do Presidente Vargas e do Brasil, me parece que tal contato seria extremamente valioso para o estabelecimento das relações da nova administração com o hemisfério ocidental. ${ }^{208}$

Além das observações contidas no relatório sobre seu encontro com Vargas após a eleição de Eisenhower, Rockefeller ainda sugeriu um rascunho de texto de carta para que o recém-eleito Presidente americano mandasse ao chefe de governo brasileiro, como começo das relações pessoais necessárias. Entre outras coisas o rascunho de

205 No original, "air bases on the Bulge", o que pode ser interpretado como saliência, protuberância, ou curva. Pelo contexto entendeu-se que eram as bases aéras na costa curvilínia do nordeste brasileiro.

206 Documento 42.

207 Documento 42.

208 Documento 42. 
Nelson ${ }^{209}$ sugeria uma humilde postura de aproximação pessoal e elogios à pessoa de Vargas e ao Brasil.

Os interesses econômicos e principais empresários americanos ocuparam papel de destaque no governo Eisenhower, que propunha uma administração mais enxuta e eficiente do que o seu antecessor. ${ }^{210}$ Por isso, logo que entrou fez as reformas administrativas propostas por Rockefeller e ocupou seus principais ministérios com figuras de destaque do meio empresarial. Isso se refletiu também na nova agência de informação, que propunha cortar gastos desnecessários e limpar de seus quadros os funcionários "comunistas".

Como comentava o senador republicano Homer W. Capehart, alinhado com a nova proposta que criava a USIA: "[a tarefa da Agência] é vender os EUA ao mundo, assim como um gerente de vendas oferece um Buick ou um Cadillac, ou um rádio, ou um aparelho de TV" (Bogart, 1995, p.xvii). E para comandar a primeira direção da agência ninguém mais apropriado que Theodore Streitbert.

Com longo passado longo no curso de administração em Harvard, nos anos 1920 e 1930, membro do grupo estudantil de Harvard, Phi Beta Kappa, ${ }^{211}$ fundador, diretor e Presidente da rádio nova-iorquina WOR, de 1935 a 1953, ele também foi consultor do PAO (Public Affairs Officer) na Embaixada Americana da Alemanha até assumir a direção da USIA.

Entre as primeiras providências da primeira direção da USIA, foi a de resolver uma das maiores críticas que o serviço de informação de Truman sofria da oposição macarthista do Congresso, a "infestação" de comunistas entre seus quadros.

Com maioria republicana no Senado, Streitbert ganhou liberdade para despedir, até $1^{\circ}$ de janeiro de 1954, qualquer funcionário da área de informação que fosse suspeito, pelo Congresso, de comunismo.

209 Documento 42.

210 Segundo Sellers, May; Mcmillen (1990, p.379), apesar da retórica de mudança adotada por Eisenhower, a linha de política externa continuou a mesma.

211 Segundo perfil sobre Streitbert, em relatório para Nelson Rockefeller. Em Documento 44 . 
Muitos dos funcionários da USIA e do Departamento de Estado, ligados aos democratas, se anteciparam e pediram demissão.

Segundo a publicação Congressional Quarterly, ${ }^{212}$ a intenção de "limpar" a nova agência era principalmente política: "[o novo orçamento aprovado da USIA, que dá autoridade ao novo diretor, até primeiro de janeiro de 1954, para despedir qualquer funcionário um movimento descrito como] pensado para extirpar Democratas e incompetentes". 213

Streitbert se preocupava com a tendência expansionista herdeira do Império Russo, que usava como armas a ideologia e a propaganda comunista, mas na verdade era o interesse imperial da velha Rússia que continuava motivando as ações do bloco soviético. Para ele, a luta ideológica era desigual e como em Davi e Golias, os EUA - que tinham um aparato infinitamente menor - deviam acertar seu ataque de maneira certeira. Só assim poderiam ganhar a batalha ideológica. Por isso, para ser eficiente, em cada lugar era necessário ter uma estratégia apropriada e eficiente. ${ }^{214}$

A gestão de Streitbert foi marcada pelos iniciais grandes cortes iniciais: orçamentário (de 36\% - US\$ 75 milhões em 1953 para US\$ 59 milhões em 1954); de pessoal (do total de 13.500 funcionários em 1952, para 9.281 no final de 1953); de bibliotecas no exterior, de 184 em 65 países para 158 em 63 países; e de postos locais no exterior, de 255 em 85 países para 217 em 76 países. Inicialmente, a única área da USIA que aumentou foi a de parcerias com o setor privado, por meio do Office of Private Cooperation, que começou a abarcar maior número de atividades ligadas a empresas e organizações não governamentais no exterior. ${ }^{215}$

212 Volume Congress and Nation 1945-1960, p.214. Em Documento 33.

213 Documento 33. Bogart (1995, p.xvi) destaca que, mesmo em um ano de aperto orçamentário, a USIA gastou cerca de US\$ 5 milhões em encargos profissionais para a recisão dos funcionários dispensados.

214 Documento 45.

215 Documento 37. 


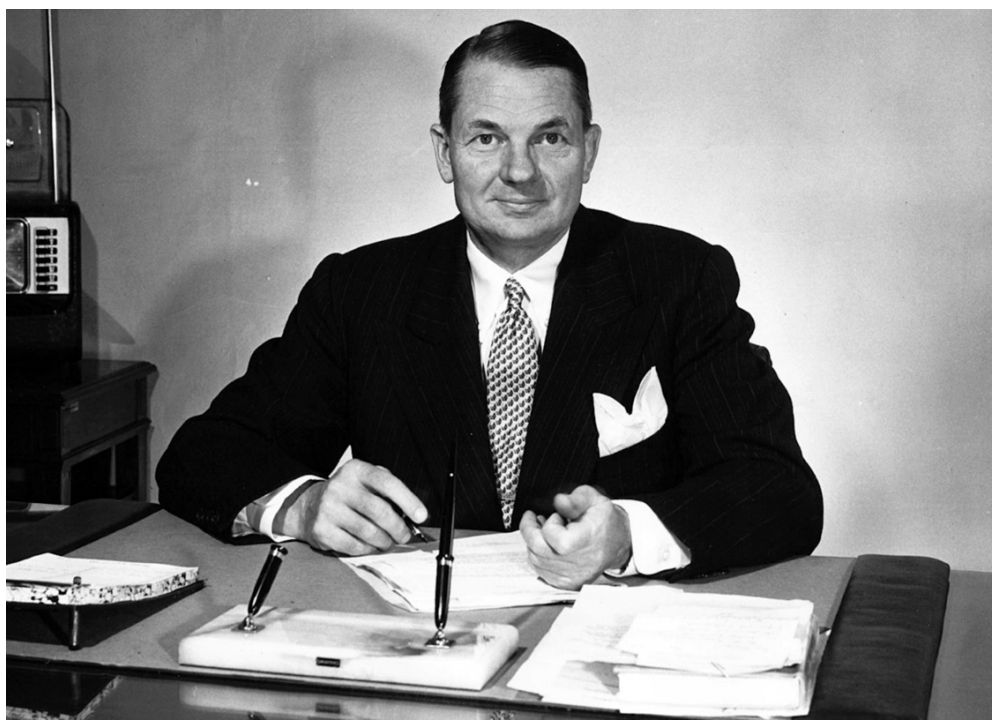

Figura 9 - Theodore Streitbert, o primeiro diretor da USIA: business man de Harvard e do rádio.

Na América Latina, a orientação dada pelo Departamento de Estado para toda ação internacional era de cooperação para o desenvolvimento econômico. Para o Secretário de Estado, John Foster Dulles, o desenvolvimento econômico privado era a arma mais eficiente para afastar o comunismo do hemisfério, nem que esse tivesse que ser induzido pelo governo:

O padrão de vida na maioria da América Latina é baixo e há grandes e barulhentos segmentos que colocam a culpa de tudo nos EUA. Nosso programa de segurança mútua vai levar em consideração a importância do crescimento econômico e da melhora dos padrões de vida na América Latina. A principal contribuição que nossa nação pode dar é por meio da livre iniciativa. No entanto, isso pode e deve ser complementado por certas medidas governamentais. ${ }^{216}$ 
Ao mesmo tempo, Dulles reconhecia a eficácia das políticas de informação na América do Sul, com relativamente pouco investimento: "Não há área no mundo onde tanto pode ser realizado por meio de boas relações culturais, eu acho, do que na América do Sul. Isso, felizmente, é algo que não nos custa muito em dinheiro". ${ }^{217}$

Mais uma vez, o Secretário de Estado também destacava a eficácia de fundações privadas na região, que influenciavam mais do que qualquer outra ação, principalmente a Fundação Rockefeller: "a fundação Rockefeller, eles fizeram mais para ganhar boa vontade na América do Sul do que qualquer outra organização, há tempos, pelo seu trabalho na área da saúde [...] Isso tem uma tremenda influência". ${ }^{218}$

Para as políticas de informação, a orientação era agir de acordo com a peculiaridade de cada país, medida frequentemente por pesquisas quantitativas e qualitativas, estabelecendo políticas de curto e longo prazo.

Para as de curto prazo, além da produção de informação disseminada por agências de notícias, filmes e rádio, a USIA continuava a promover intercâmbios de lideranças, turnês de artistas e intelectuais americanos e produzir materiais gráficos para determinados setores, como sindicatos, igrejas e associações estudantis. A agência também promovia exposições ${ }^{219}$ sobre temas que demonstravam o progresso americano, desde a agricultura, veículos, até a energia atômica.

Para as políticas de informação de longo prazo, a grande arma na região eram os centros binacionais, que contavam com bibliotecas, ofereciam aulas de inglês, exibiam filmes educativos e documentários, e distribuíam materiais produzidos pela USIA.

Os centros binacionais no Brasil eram os mais numerosos e os mais exitosos. Segundo Streitbert, "os centros são muito ativos no

217 Documento 46.

218 Documento 46.

219 Em uma dessas aconteceu o célebre debate na cozinha entre Kruschev e Nixon, discutindo as diferenças entre os modos de vida soviético e americano. Sellers; May; McMillen (1990, p.389). 
Brasil. Durante a minha estada no Rio eu discuti sobre eles com nosso embaixador, Sr. Kemper, que é um entusiasta do tema. Há cerca de 30 no Brasil hoje em dia, mas ele gostaria de ver dobrar esse número". 220

Após o grande corte inicial do primeiro ano, a USIA começou a se reestruturar e ampliar alguns dos seus serviços. Streitbert propôs um plano para qualificar o pessoal dos postos no exterior e dar-lhes novas atribuições. No final de 1953, a USIA, com 9.281 funcionários, tinha a maioria deles nos postos do exterior (7.262, sendo 6.136 estrangeiros e 1.126 americanos), e 2.019 funcionários nos EUA.

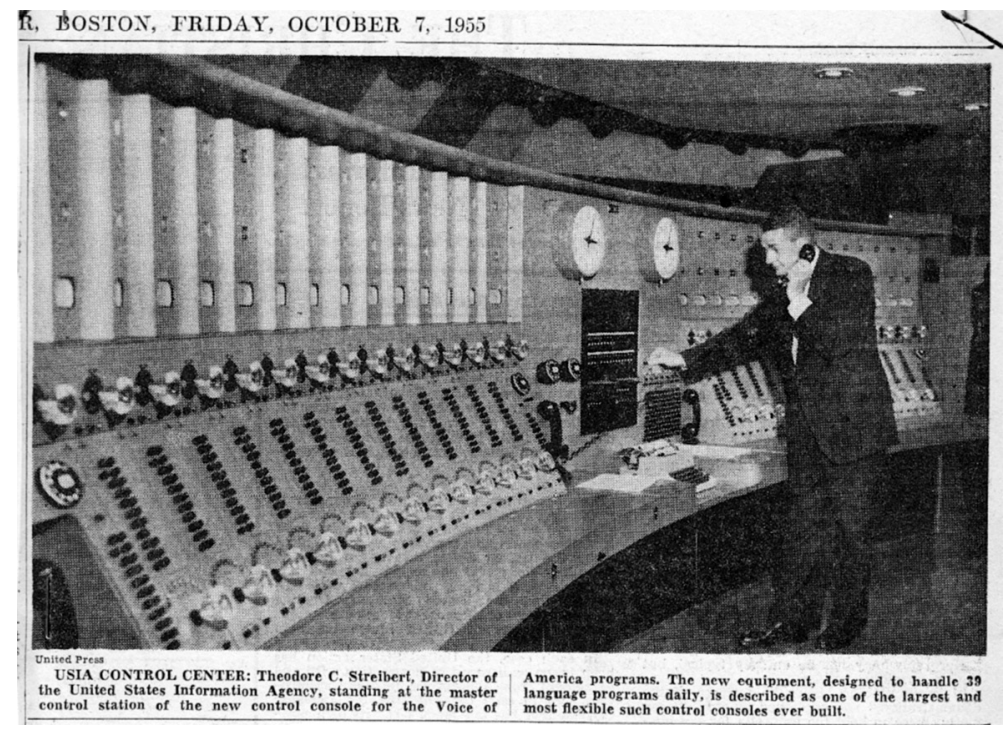

Figura 10 - A USIA começava a se expandir, também com o Voice of America.

A grande maioria dos funcionários da USIA se dedicava aos USIS (6.517), em um número menor ao serviço de rádio (1.591), e depois aos serviços de imprensa (477), depois ao departamento de filmes (136 pessoas), e por fim ao centro de informações (132 pessoas). Ainda, havia os funcionários dos escritórios centrais da USIA, 
o do diretor, em Washington D.C. (183 pessoas) e a sua equipe de apoio (245 funcionários). ${ }^{221}$

No mesmo ano, o VOA anunciava seu balanço de atividades, destacando maior alcance de suas mensagens (de teor anticomunista) por meio de parcerias privadas, com um quadro de funcionário menor e com um gasto menor em relação à administração do último ano do IIA. ${ }^{222}$ Já nos primeiros anos da USIA, a VOA transmitia mais de 210 mil palavras por dia, e 28 horas de programação em 34 línguas diferentes (Bogart, 1995, p.xiv).

Após o corte e as remodelações propostas por Streitbert, houve já em 1954 um aumento no número de funcionários para o nível anterior à criação da USIA, e que se manteve ao longo dos anos 1960. Em 1954, havia 12.877 funcionários (com 2.820 nos EUA e 10.057 no exterior, a maioria deles estrangeiros). A proporção se manteve como os números de 1954, com variações ínfimas, ao longo da década.

A partir de 1954, a USIA começa a se estruturar da maneira pensada e proposta por Eisenhower. A rádio, atividade principal da agência até o momento, se aproxima mais da sede da USIA, que se localizava na Pennsylvania Avenue, 1778. ${ }^{223}$ Para a mudança da sede do Voice of America, de Nova York para Washington D.C., a USIA gastou cerca de US\$ 4 milhões. ${ }^{224}$

No mesmo ano, as turnês de esportistas e artistas no exterior têm amplo destaque. Turnês de atletas de basquete, beisebol, futebol, tênis e natação começaram a fazer sucesso. ${ }^{225}$ Para a arte, a USIA adquiria algumas obras com apoio principalmente do acervo dos museus americanos e colecionadores privados, que cederam suas obras primas. Assim, a agência organizava exibições de sucesso em seus centros binacionais e museus ao redor do mundo. ${ }^{226}$

221 Documento 48.

222 Documento 51.

223 Documento 35.

224 Despesa destacada em Bogart (1995, p.xvi).

225 Documento 50.

226 Documento 50. Um livro fundamental sobre a política de arte dos EUA no exterior durante a Guerra Fria, e de como a Arte Moderna foi usada como 
O jazz era a grande arma musical no front da Guerra Fria. ${ }^{227}$ Tanto nas turnês, quanto na exibição diária nos programas de rádio produzidos pela USIA, ou patrocinados por empresas americanas no exterior. Segundo reportagem do New York Times de 5 de Novembro de 1955 :

A arma secreta da América é uma "blue note" em um tom menor. Atualmente nosso embaixador mais eficiente é Louis (Satchmo) Armstrong. Um som sincopado de uma banda de Dixieland ouvido no Voice of America na longínqua Tanger é como uma frase de propaganda. Este não é um devaneio em uma jam session, na sala dos fundos. É a conclusão de um estudo de muitos dos pensadores americanos de Moscou a Madri... Jazz não é somente uma arte. É um modo de vida. 228

A grande demanda pelo jazz impôs ao governo que fossem estabelecidas as turnês dos músicos de maior sucesso, principalmente voltadas para o público jovem:

...em 1956, como resultado de muitas pesquisas de campo, [isso] foi aceito por enormes plateias, em que estudantes e outros jovens eram a maioria. Entre os grupos de jazz enviados para turnês estavam Louis Armstrong, Dave Brubeck, Benny Goodman, Sauter-Finegan, e Jack Teagarden. ${ }^{229}$

Uma das organizações envolvidas na elaboração e promoção de muitas das turnês artísticas patrocinadas pelo Governo Americano (ou pelo Departamento de Estado, ou por um fundo especial da

expressão que representava a liberdade e a democracia americana, é o "How New York Stole the Idea of Modern Art”, do francês Serge Gilbaut (1983).

227 A obra referência sobre o uso do jazz na Guerra Fria é o "Satchmo blows up the world, Jazz Ambassadors Play the Cold War”, de Penny M. Von Eschen (2004).

228 Documento 50.

229 Documento 50: "1956: American Jazz introduced into cultural program because of overseas demand". 
Presidência, ou pela USIA) era a American National Theatre and Academy (ANTA). ${ }^{230}$

As Repúblicas Americanas eram a última região em número de turnês artísticas e esportivas. Para o ano de 1956, enquanto no Oriente o governo despendia US\$779 mil com atividades esportivas e artísticas; no Oriente Médio e Ásia, US\$ 680 mil; na Europa, 542 mil; nas Américas, as turnês custavam US\$446 mil para o governo.

Desse montante dedicado às Repúblicas Americanas, no ano de 1956, US\$ 168 mil eram gastos com grupos teatrais, de drama, comédia e musicais; US\$ 99 mil para grupos musicais; US\$ 90 mil pra orquestras; US\$ 62 mil para atividades esportivas; US\$ 15 mil para grupos de dança e apenas US\$ 11 mil para artistas individuais nas Américas. ${ }^{231}$

Além da parceria com organizações privadas no rádio, imprensa, música e artes plásticas, a USIA aumentou o alcance dos seus filmes produzidos também por meio de exibições conjuntas com filmes comerciais. Utilizando os canais de exibição privados, os filmes da USIA tiveram 200 milhões de espectadores por semana, no ano de 1954. Mais de 700 rolos de novos filmes da USIA, em 40 línguas, (totalizando 12 mil rolos, de mais de 200 diferentes filmes) foram distribuídos para exibição em salas comerciais Warner Brothers, da RKO, 20th Century Fox e Paramount ao redor do mundo. ${ }^{232}$

O ex-executivo da área e chefe do Departamento de Filmes da USIA, Andrew W. Smith, explicava a estratégia da USIA para usar os filmes como forma de combater o comunismo:

Filmes ainda são um dos meios mais perceptíveis de trazer a história da política externa americana para os povos das nações livres, e expor os falsos e traiçoeiros argumentos dos propagandistas

230 Documento 50: "ANTA to sponsor two music tours".

231 Idem: "1955-56: Breakdown FY56 Cultural-Sports Program by area $\mathcal{E}$ activity”.

232 Documento 51: Notícia do "Herald Tribune Bureau", de 1o de agosto de 1954: "USIA Film Audience Increased by 200 Million". 
vermelhos. Os filmes atuais da USIA estão claramente servindo a um importante propósito. ${ }^{233}$

A USIA estabelecia três novos critérios que deveriam ser buscados para a produção de seus novos filmes: 1. O teor anticomunista; 2. Que reforce o interesse da política externa dos EUA no país em que é exibido; 3. Que aborde atualidades do noticiário local, em formato de notícias (newsreels), misturando o conteúdo político com temas de interesse. ${ }^{234}$

Para o formato de filmes documentários sobre determinado tema de interesse, a USIA iria investir US\$205 mil para o ano de 1956. Para a produção de filmes com noticiário sobre determinado tema (como por exemplo, a visita de Milton Eisenhower à América do Sul), a USIA destinou US\$175 mil naquele ano. E para a produção de newsreels era destinado o maior montante anual (US\$ 650 mil), sendo que $60 \%$ desses eram produzidos localmente, com menor qualidade técnica, mas com maior credibilidade.

Para Streitbert, produzir filmes não assinados pela agência ou pelo governo era um princípio da USIA. Segundo ele, isso facilitava a aceitação das mensagens em públicos estrangeiros:

Agora, essa é, quase que inteiramente, uma operação confidencial. Eu tentarei descrevê-la genericamente para que possamos discuti-la sendo registrados. Na verdade, a maioria de nossos filmes são clandestinos, e nós acreditamos que isso é muito mais eficiente, não ter o "carimbo" da USIA nesses filmes. Isso é especialmente verdade para a nossa produção estrangeira. Nós procuramos não identificá-los como filmes dos EUA. ${ }^{235}$

233 Documento 51: Notícia do "Herald Tribune Bureau", de 1o de agosto de 1954: "USIA Film Audience Increased by 200 Million".

234 Documento 51: "Streitbert - interested in 3 types of films (anti-communist, Pro-US Foreign Policy, Topical)”.

235 Documento 51: "1955: Streitbert-Agency produces 3 types of films: documentaries, newsreels and topical films: most unattributed: major emphasis on newsreels". 
Definidas as principais áreas e maneiras de atuação, a USIA começava a se organizar definitivamente. Em 1956, o organograma da USIA já se dividia em 11 Departamentos ao total. Por tema de trabalho eram: o do diretor; o do conselho geral; o da cooperação privada; o de pesquisa e inteligência; o de segurança; o de administração; e o do diretor assistente, responsável pelo Departamento de políticas e planos. E por região: o do diretor assistente para as Repúblicas Americanas (Frank H. Oram); o do diretor assistente para Europa; o do diretor assistente para o Oriente; o do diretor assistente para Oriente Médio, Sul da Ásia e África.

Cada escritório regional tinha as diversas representações locais, por meio dos centros de cultura, bibliotecas, centros binacionais, embaixadas, consulados e dos United States Information Services (USIS).

Respondiam também ao diretor os serviços de mídia, que tinham representações locais e se dividiam em quatro setores de atividades: o centro de informação; o de filmes; o de transmissões (com representações locais nos centros de rádio e bases de transmissão regionais); e o serviço de imprensa (com postos locais de produção de notícia).

Como bem ilustra o organograma abaixo, basicamente a estrutura de trabalho da USIA se dividia entre Staff Offices, os Media Services, a Geographic Direction e as Overseas Operations:

A partir do estabelecimento da estrutura interna da USIA, o programa de informação norte-americano definia também as responsabilidades com outros órgãos do governo. A partir das diretrizes presidenciais, definidas por meio das recomendações do National Security Council (e de seu Operations Coordinating Board), a USIA era quem conduzia as ações definidas pelo Presidente no exterior. ${ }^{236}$

O Departamento de Estado era responsável pelo estabelecimento das diretrizes de política externa a ser seguida por todas as agências. Nos postos diplomáticos ao redor do mundo, o chefe da missão (embaixador ou cônsul) era o responsável por definir as políticas

236 Documento 51: "Operating Responsabilities and Relationships for the United States Information Agency, March 4, 1954”. 
Organization of the U. S. Overseas Information Program, 1945-1958

Attachment $\mathrm{E}$

\section{UNITED STATES TNFORMATION AGENCY} 1956-1957

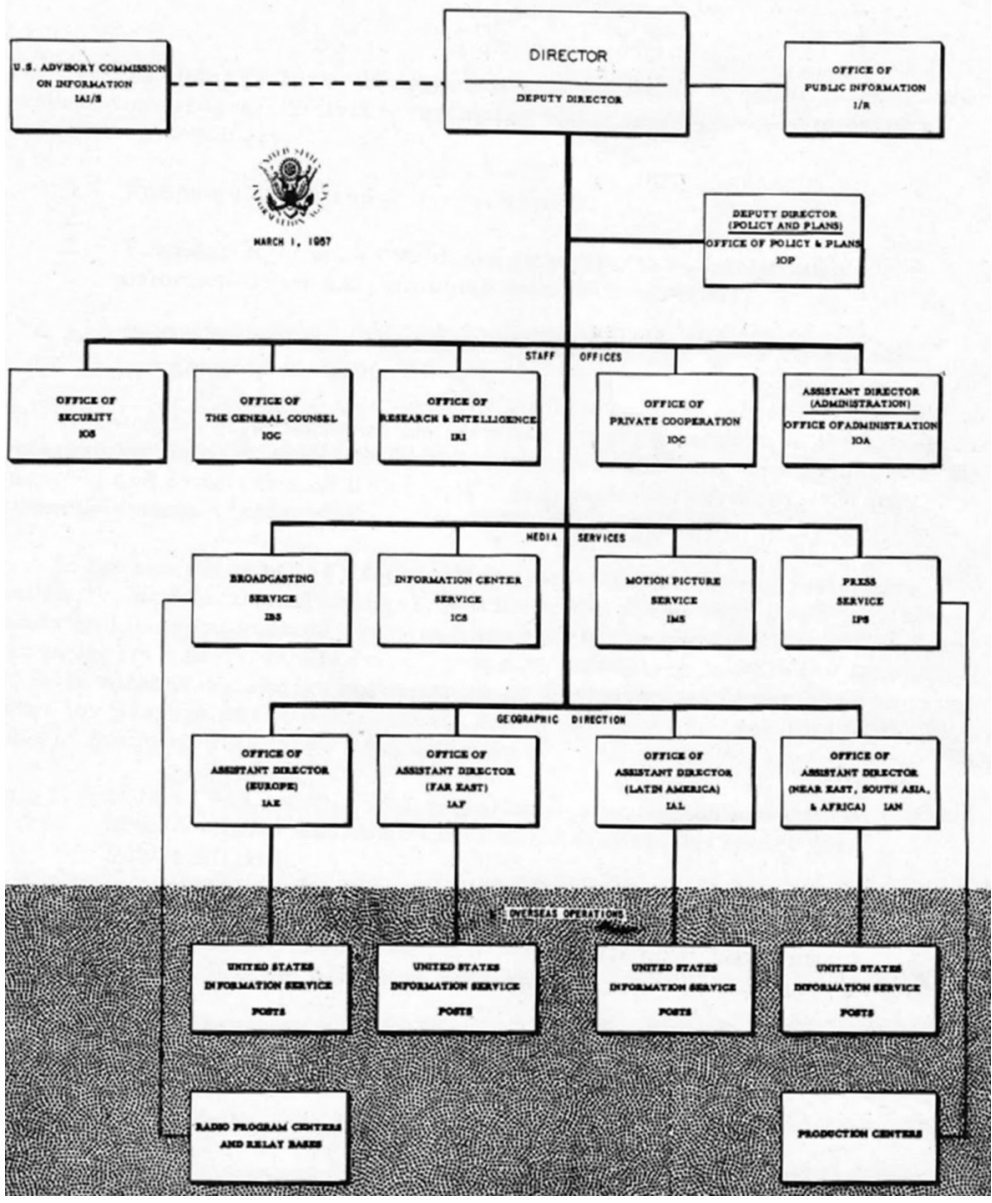

Figura 11 - O organograma da USIA a partir de 1956: a estrutura básica da agência em seus anos de apogeu. 
de informação prioritárias para cada local. ${ }^{237}$ As outras agências e Departamentos do governo deveriam abastecer a USIA com dados referentes às políticas de informação, relacionados às suas áreas. As de inteligência (como CIA) deveriam fornecer todo tipo de informação estratégica para USIA. ${ }^{238}$

Além da criação e estabelecimento das ações da USIA, Eisenhower lançou o seu mais ambicioso plano de informação, em setembro de 1956, que ia totalmente de encontro às parcerias com as empresas e a sociedade civil propostas também pela USIA: o programa People-To-People. A principal ideia do governo era estabelecer uma plataforma com diversos eixos de ação para estimular as relações da sociedade civil e empresarial americana com outros países. Apesar de ser uma iniciativa que partiu do governo, a ideia era que o programa tivesse caráter de fundação independente e privada.

É interessante notar que, entre os variados materiais gráficos que foram produzidos para promover o programa People-To-People, diferentes referências de organizações do governo, ou de fundações privadas, eram mostradas.

Outras vezes, dependendo do tipo de comitê ou informação que esses promoviam, quem aparecia como referência era o próprio endereço da USIA, em Washington D.C. (como no material a seguir):

O programa seguia à risca a estratégia histórica das políticas de informação americana, de muitas vezes não serem identificadas oficialmente como governamentais, para ser melhor aceita em outros países. No lançamento da iniciativa, em uma conferência na Casa Branca que reuniu cerca de 50 lideranças econômicas, sociais e culturais que seriam indicados pelo governo como coordenadores de comitês, Eisenhower explicava que o programa teria um caráter privado, não-governamental..$^{239}$

237 Documento 51: "Operating Responsabilities and Relationships for the United States Information Agency, March 4, 1954”.

238 Documento 51: "Operating Responsabilities and Relationships for the United States Information Agency, March 4, 1954”.

239 Documento 52. 


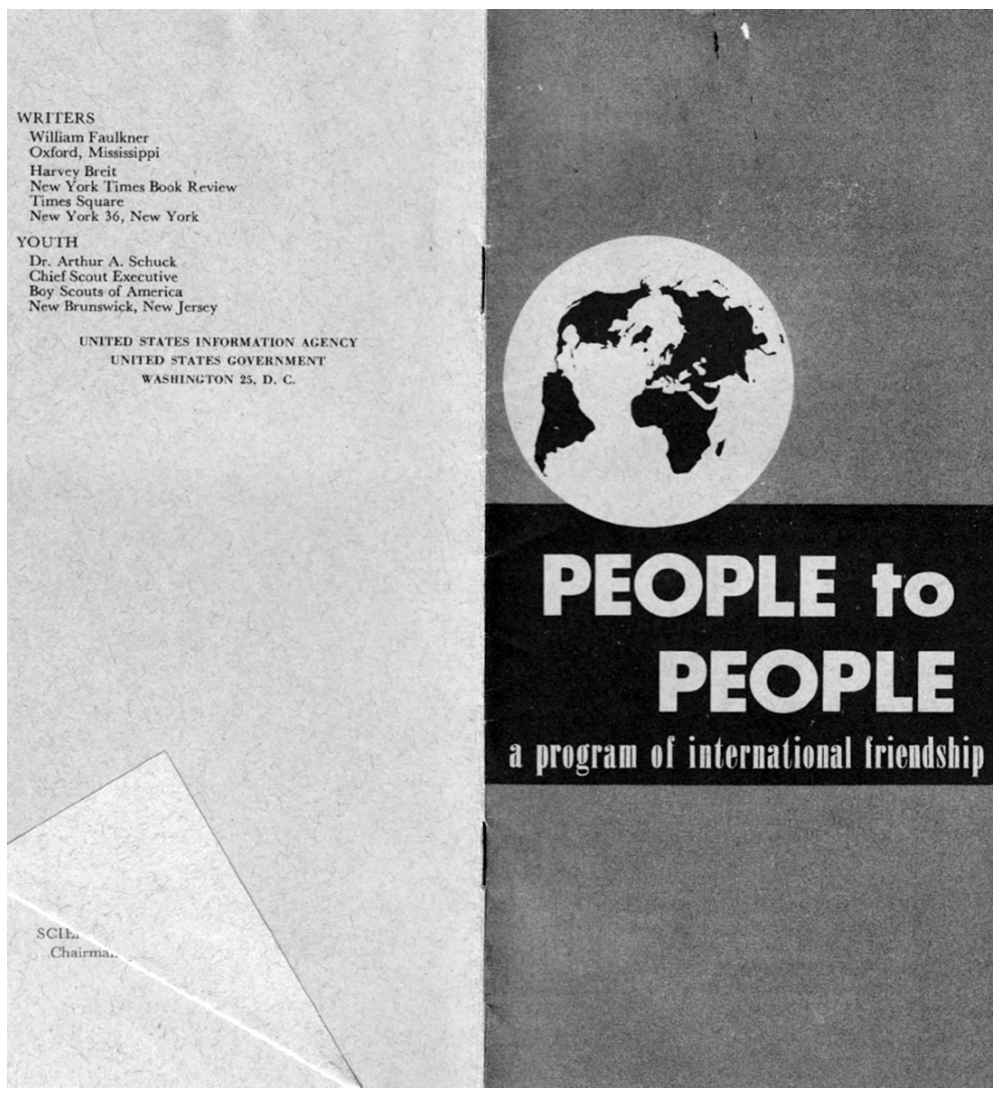

Figura 12 - Folheto de apresentação do programa People-to-People, lançado por Eisenhower em 1956, com a USIA como referência de contato.

Na ocasião, Eisenhower e Foster Dulles detectavam que os governos tinham caráter limitado e que a sociedade civil deveria exercer o papel de facilitadora na aproximação do governo americano com outros governos no exterior. Cada comitê, a partir das nomeações das coordenações feitas pelo governo, deveria ter autonomia para pensar suas ações e estratégia. ${ }^{240}$ 
Entre os 41 comitês, eram citados inicialmente pelo governo os de: organizações de propaganda; serviços militares; bancos; livros; organizações para negócios; cartunistas; comitê cívico; educação; grupos agrários; artes plásticas; política externa; grupos de ex-funcionários de serviços no exterior; grupos "4-H" (organização juvenil, nos moldes aproximados do escotismo); fraternidades estudantis; deficientes; hobbies; indústria hoteleira; seguros; de cartas; revistas; profissões de medicina e saúde; filmes; música; nacionalidades; relações públicas; rádio e TV; grupos religiosos; ciência e engenharia; service organizations (organizações como Rotary, Lions, etc.); porta-vozes; esportes; talentos para indústria de entretenimento; viajantes; veteranos militares; mulheres; escritores; e juventude. ${ }^{241}$

A proposta do governo era de que os comitês nacionais desenvolvessem as relações com suas contrapartes no exterior, sejam elas governamentais ou privadas. $\mathrm{O}$ comitê de cartas, por exemplo, deveria buscar partilhar ações com organizações que promovessem o contato de americanos com estrangeiros por meio das cartas. Segundo a USIA:

Cartas pessoais, o segundo meio mais antigo das comunicações entre os homens, ainda são uma de nossas armas mais confiáveis na batalha de ideias. Jornais, periódicos e livros são frequentemente barrados, ou censurados. Nossas mensagens de rádio são muitas vezes distorcidas pela oposição. Fotos podem ser falsificadas. Mas a correspondência chega às áreas mais difíceis do mundo, onde a mente dos homens está em jogo. ${ }^{242}$

É interessante notar que tendo como referência a Fundação People-to-People, com sede em Nova York (no número 45 leste da rua 65 ) os materiais muitas vezes se referem como uma iniciativa

241 Documento 52.

242 Documento 53: Letters abroad from Americans: How can you help the U.S. Government Develop a better Understanding Throughout the World (USIA). 
presidencial. As publicações pediam a ajuda das pessoas para, ao criarem novas amizades no exterior, ajudar a garantir a paz mundial. Como no material gráfico a seguir:

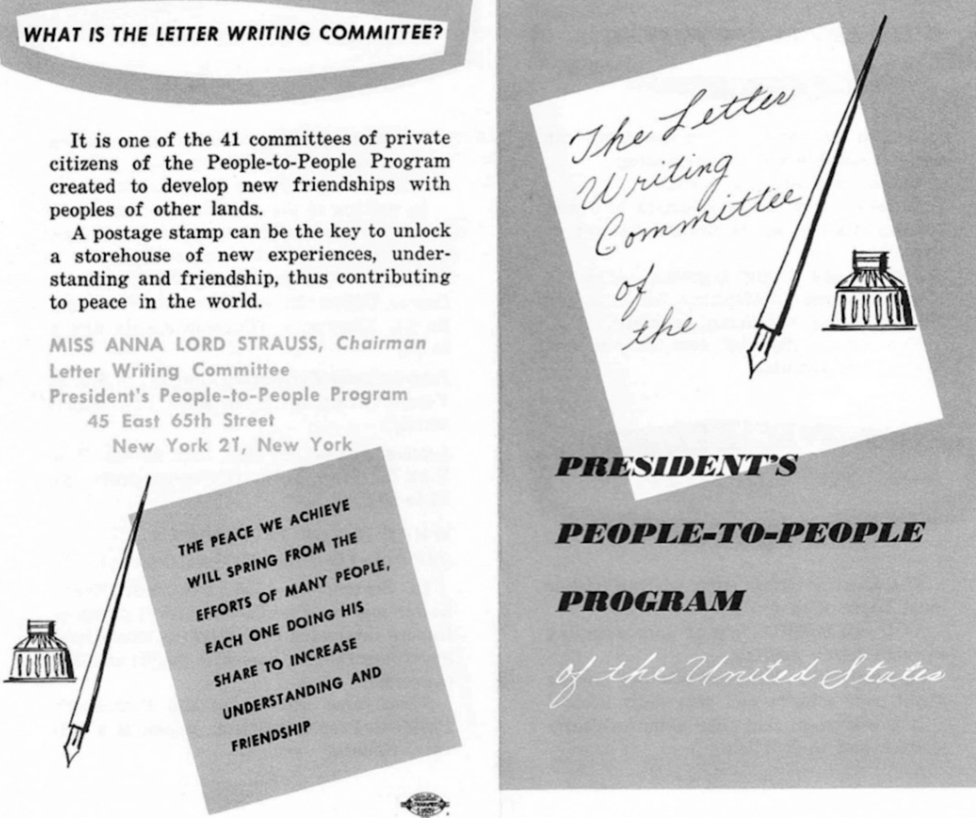

Figura 13 - Folheto de apresentação do comitê de cartas, do programa People-to-People, lançado por Eisenhower em 1956.

Outros comitês, como o de hobbies, por exemplo, desenvolviam a troca de experiências com relação aos mais variados costumes, como a coleção de selos, moedas, ou antiguidades; como o gosto por animais, autógrafos, cerâmicas, bonecas, ciclismo, viagens, mágica, estudos naturais, maquetes, fotografias, gravação de fitas, jornalismo amador, escalada ou jardinagem. ${ }^{243}$

Todos esses hobbies eram motivo para envolver as pessoas no esforço do Presidente para a segurança mundial. Grande parte do material analisado não deixava claro de onde partiam as fontes de 
financiamento para as iniciativas de aproximação entre os povos, e muitas vezes não havia menção direta em relação ao papel do governo. Na maior parte das vezes, continham somente frases do Presidente Eisenhower que inspiravam a luta por um mundo melhor, com base nos costumes americanos. Como mostra o formulário de inscrição para o comitê abaixo:

THERE ARE also committees for members of business organizations, the hotel industry, the medical and health professions and many other vocational groups. The committees, headed by outstanding leaders in their fields, are sources of guidance for individuals or groups who wish to add their efforts to the Peopleto-People Program.

\section{What YOU Can Do}

This is an invitation to all to join the People-to-People Program. The program is international-it jumps the boundaries of nations, races and creeds.

To join the People-to-People Program you don't have to pay any dues, fill out any application forms or go through any other formalities. You simply write to People-to-People-you can use the handy form provided in this booklet-indicating the hobby or hobbies you're interested in and asking how you can share in this adventure in international friendship. The ceniral office of People-to.People will refer your inquiry to the appropriate hobby group. Act on the information you receive and you become a full-fledged partner for peace in the People-to-People Program. Your favorite hobby may provide the starting point for an enriching exchange of ideas and experiences with someone in a foreign land.

TO: People-to-People Hobbies Committee, Incorporated 153 Waverly Place

New York 14, New York

Please let me know how I can become a partner for Peace through the People-10-People Program. I am interested in the hobbies listed below:

Name:

Address:

Note inside pages for hobby classifications.-

\section{PEOPLE-TO-PEOPLE HOBBIES COMMITTEE \\ INCORPORATED \\ 153 Waverly Place \\ New York 14, N. Y}

Officers

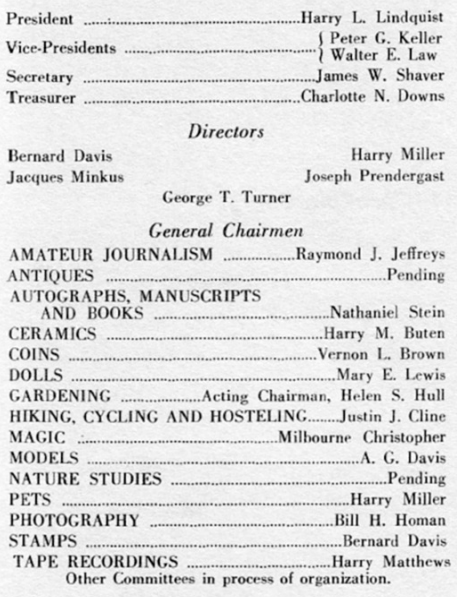

For the Hobbies Committee

ART DIRECTOR Frane Ritter COUNSELOR ........................................... Wickersham PUBLIC RELATIONS ........................... Ward B. Stevenson

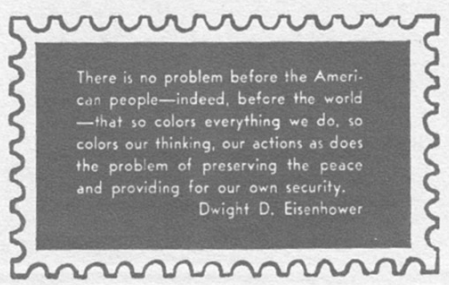

Figura 14 - Formulário para inscrição no comitê de Hobbies, do programa People-to-People, fundado por Eisenhower em 1956. 
O People-to-People também inovava, contemplando as minorias, como comitês de deficientes ou de mulheres. $\mathrm{O}$ folheto de divulgação, patrocinados pela companhia Hughes Aircraft Company, da Califórnia, tentava mostrar que a democracia americana era superior, pois previa ajuda àqueles mais necessitados:
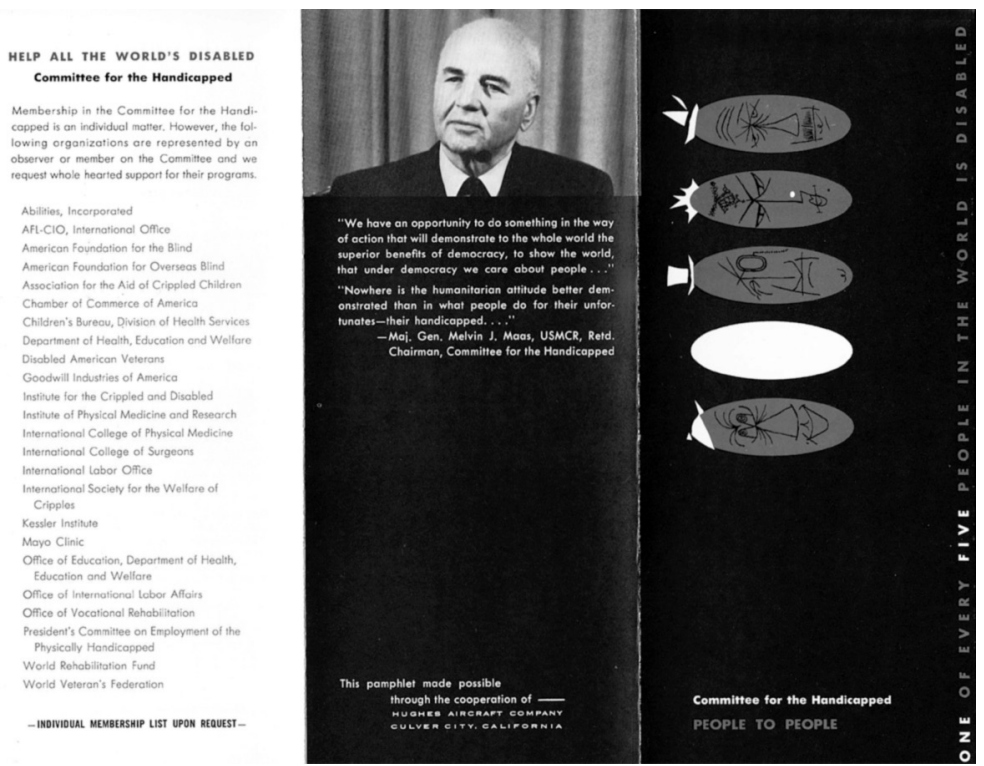

Figura 15 - Material de apresentação do comitê de deficientes do programa People-to-People, fundado por Eisenhower em 1956.

O comitê de deficientes tinha como associados alguns departamentos governamentais, como o de saúde, educação e bem-estar, o de relações internacionais, do trabalho, o da reabilitação vocacional, além de associações como a Federação Mundial de Veteranos de Guerra, uniões sindicais como a AFL-CIO (American Federation of Labor and Congress of Industrial Organizations) e associações empresariais como a Câmara Americana de Comércio.

Além dos comitês, o People-to-People encorajava a sociedade civil, até individualmente, a se engajar na luta do governo pela paz. Isso era feito por meio da aliança com outras pessoas e organizações do mundo, com iniciativas como a campanha de conscientização dos 
viajantes ao exterior, que fora do país representariam a democracia americana e por isso deveriam fazer - além de negócios ou boas experiências pessoais - com que a imagem dos EUA melhorasse junto àqueles com quem tivessem contato.

Materiais específicos para viajantes eram produzidos no formato de passaporte e pediam para que estudantes, empresários, missionários, turistas ou americanos que fossem visitar o país de seus antepassados representassem bem o país no exterior e respeitassem os costumes locais. Além disso, o material pedia para que o viajante americano buscasse o que fosse comum entre os EUA e o país visitado, para assim fazer novas amizades, duradouras, fora dos EUA. ${ }^{244}$ A foto a seguir, capa e contracapa do folheto distribuídos aos viajantes americanos (encontrada no acervo de materiais produzidos pela USIA durante o governo Eisenhower), mostra a ideia da campanha (não-assinada) da USIA:

of these lands, but among the feelings and impressions that people hold about Americans, my interest will be to appreciate their manners and customs, not to insist on imitations of the American way of doing things.

For it is not steel or oil or wheat or dollars that represent the most important products of my country. It's people-like me-one after another passing through the large and little places of the world. And it's millions like me-not the small number of diplomats'or official emissaries - who are most seen and heard and talked about by the masses of people over the world.

There's a little old man, they say, who sells blossoms by a garden wall in a country corner. He drops clumps of flowers, roots and all, at the feet of visitors and cries cheerily:

"Stick'em in the ground and they'll grow for ye."

To the countries and people abead, who want to know more about us and know us better, $\mathrm{Im}$ going to carry the blossoms, roots and all, of the United States of America. I'm going to plant good will wherever I go, and let it grow ... to make friends for myself and for my country.

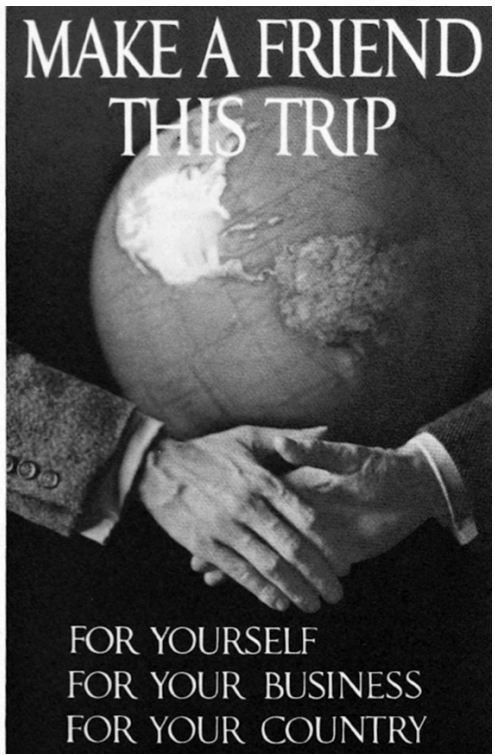

Figura 16 - Material produzido pela USIA, durante o governo Eisenhower, para viajantes americanos que partiam ao exterior. 
A mensagem "For yourself, for your business, for your country" conclamava ao cidadão comum o papel de representante do país no exterior, dando-lhe importância maior do que os diplomatas ou enviados de governos. Produzido por iniciativa do governo, era uma ode à importância da sociedade civil, em uma guerra que decidiria o futuro da humanidade. ${ }^{245}$

O vasto programa People-to-People também incentivava a criação espontânea de comitês locais, que poderiam criar sua própria agenda de cooperação (cartas, esportes, envio de livros ao exterior, missões técnicas, esportivas, musicais ou acadêmicas), que poderia ser encaminhada e apoiada por uma das representações do programa, identificada somente por um número de Caixa Postal "People-to-People Councils", PO Box 1960, Washington D.C.

A produção da cartilha, distribuída às organizações comunitárias de bairro, era um oferecimento da Fundação Hallmark (empresa que produz cartões de aniversário e festas). Ao final do cartão, a Fundação agradecia à USIA e ao seu Departamento de cooperação privada (Office of Private Cooperation), conforme mostra a Figura 17:

\section{THIS IS A \\ DOIT, YOURSELF PROJECT}

You personally can help bring about better understanding between peoples.

You personally can work for peace through People-to-People contacts.

You personally can organize a Peopleto-People Community Council. Do it now. Write today. Send your letter to:

PEOPLE-TO-PEOPLE COUNCILS POST OFFICE BOX 1960 WASHINGTON, D. C.

Remember

Peace begins with you.

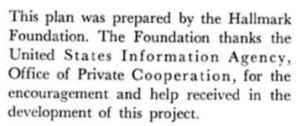

Figura 17 - Cartilha do programa People-to People para criação de projetos comunitários de cooperação, produzida pela fundação Hallmark, com ajuda da USIA.

245 Documento 52. 
As iniciativas do People-to-People previam não só a participação de comunidades de bairro, mas também da cooperação internacional das cidades americanas, por meio do comitê cívico do programa. $\mathrm{O}$ apoio à aproximação de cidades se dava especificamente pelo programa Sister Cities, também lançado por Eisenhower e acompanhado pela USIA.

A articulação com as cidades passava, internamente, pela American Municipal Association (membro do comitê cívico do People-to-People) e pelo American Committee for International Municipal Cooperation; com as cidades do hemisfério pela Inter-American Municipal Organization; e em todo mundo, pela International Union of Local Authorities (IULA).

Segundo as publicações da USIA sobre a adesão de cidades ao Sister Cities, o principal objetivo a ser seguido com o irmanamento de cidades era atingir a paz mundial, pois as cidades refletiriam o modo de vida americano, ajudariam a combater as ideias distorcidas da propaganda soviética e ajudaria a fortalecer os laços de amizade com outros povos, também ameaçados pelo comunismo. ${ }^{246}$

O ponto focal para adesão de cidades americanas ao programa Sister Cities era a sede da American Municipal Association, em Washington D.C. Muitas vezes, porém, a prospecção de parcerias entre cidades se dava pelos próprios embaixadores dos países (chefes locais dos USIS), que em contato com a USIA propunham o irmanamento de algumas cidades, de acordo com os interesses locais. No caso do Brasil, o que será visto ao longo do terceiro capítulo (mais especificamente no subcapítulo 3.5), muitas vezes os irmanamentos de cidades aconteceram com participação ativa da USIA e da embaixada local.

Os irmanamentos promoviam atividades culturais e gastronômicas, e normalmente previam um dia de festejos com costumes das cidades irmãs. Entre as atividades permanentes estavam as já previstas pelo People-to-People, como troca de cartas entre estudantes e pessoas das comunidades, reuniões sobre diversos temas (como 
hobbies, gastronomia, jardinagem, escalada, etc.) e visita periódicas entre autoridades locais. Muitas das vezes, as cidades se homenageavam, nomeando praças ou ruas em referência à cidade irmã.

Podem ser citados vários exemplos de irmanamentos ativos na ocasião, como o de Tucson (Arizona) com Trikala (Grécia), Cortland (NY) com Pashawar (Paquistão), San Diego (Califórnia) e Yokohama (Japão), Montclair (NJ) com Graz (Áustria), ${ }^{247}$ Washington DC com Tóquio (Japão), Boston (Massachusetts) e Roma (Itália), San José (California) e Okayama (Japão), Seattle (Washington) e Kobe (Japão), entre outros.

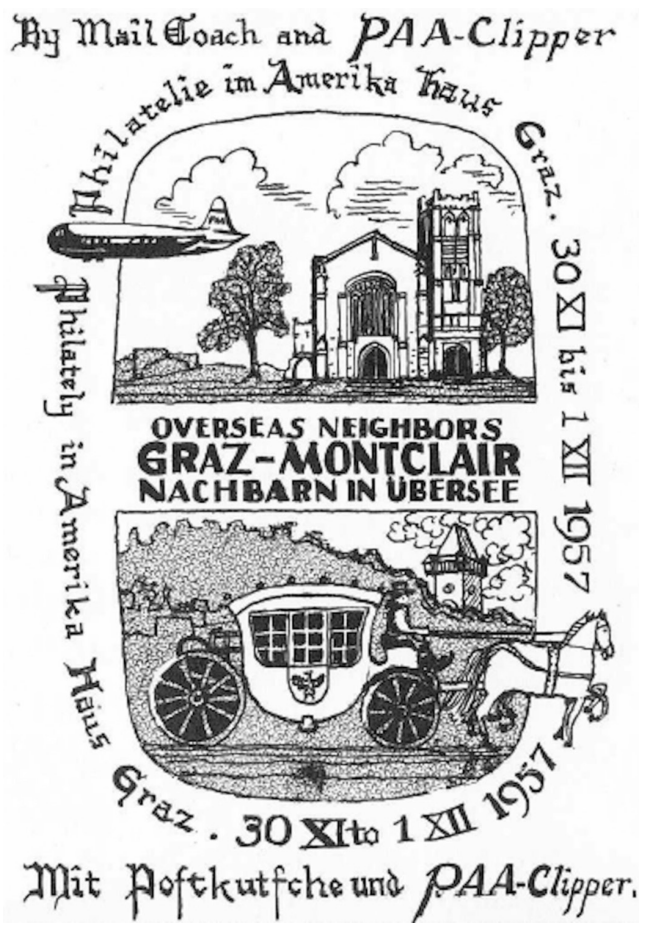

Figura 18 - Brasão comemorativo do programa Sister Cities entre Montclair (NJ) e Graz (Áustria).

247 Segundo Documento 56, o irmanamento entre Montclair e Graz foi um dos mais antigos com cidades americanas. 
Muitos dos comitês serviram para mobilização efetiva da sociedade civil no esforço da guerra ideológica anticomunista. $\mathrm{O}$ comitê de cartunistas, por exemplo, reuniu artistas que produziram materiais publicados pela USIA em outros países, muitas vezes feitos por cartunistas locais participantes do comitê do People-to-People; no Brasil inclusive.

Um desses materiais foi um livro de 95 páginas de 22 cartunistas que defendiam o turista americano como amigo das populações locais, chamado You don't see these sights on the regular tours. Ele foi distribuído em Departamentos do governo, agências de turismo, fraternidades e organizações correlatas, de acordo com notícia de jornal encontrada nos arquivos da USIA. ${ }^{248}$

$\mathrm{Na}$ charge selecionada abaixo, Walt Kelly, que fazia parte do comitê de cartunistas do programa, demonstra o bom coração dos turistas americanos, muitas vezes enganados pelos locais (como no caso da compra de estátuas incas raras, que na verdade são produzidas industrialmente), ou no caso dos jovens delinquentes de outros países, que devem tratar os americanos de maneira respeitosa, já que eles tratam os estrangeiros dessa maneira.

Segundo a reportagem, a propaganda soviética divulgava o turista americano como "fanfarrão", "barulhento" e "mal-educado", e materiais como esse tentavam equilibrar essa imagem, por meio da arte e do humor, e mostrando que o turista poderia causar uma boa impressão no exterior: 

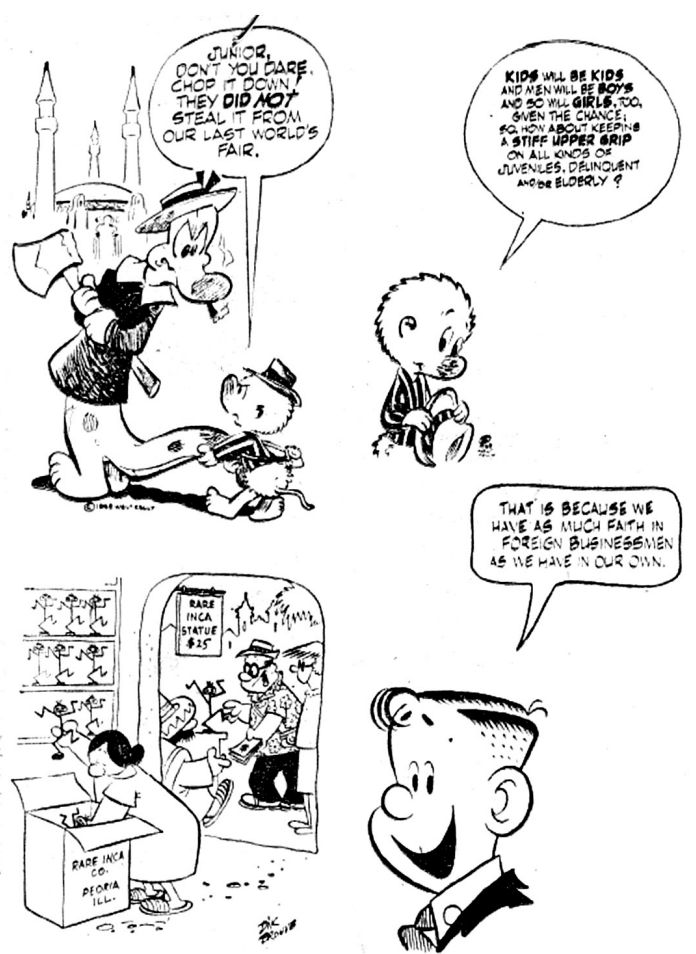

THAT IS BECALSE WE HAVE AS MUCU FATH N AE WEHAL NOLR DUN

NOT WHAT THEY SEEM-Cartoonist Walt Kelly's familiar Pogo and $\mathrm{Hi}$ from " $\mathrm{Hi}$ and Lois" offers a defense of and a warming to the American tourist abroad. Reproduced from "You Don't See These Sights on the Regular Tours," through the courtesy of the Cartoonists Committee of the People-toPeople Program.

\section{Cartoonists Defend American Tourists}

The propagandists operating |ment offices, travel agencles, against the United States say fraternal groups and other the American tourist is a boastful, bombastic and boorish bird.

To counteract that idea, 22 -

of America's leading cartoonists have lent their talents to pro-

Figura 19 - Reportagem sobre publicação de cartunistas do People-to-People, favoráveis aos turistas americanos no exterior. 
Os participantes dos comitês do People-to-People no exterior eram tão atuantes que muitas vezes exerceram papéis que ultrapassavam os seus habituais. Como na conturbada visita do então vice-Presidente Nixon à América Latina, em maio de 1958, quando foi recebido com manifestações contrárias em diversos dos países da região. Mas na Venezuela, Nixon contou com apoio de moradores locais que participavam das atividades do People-to-People. Segundo reportagem do Washington Post, intitulada "Hobby Found Peacemaker in International Strife", os membros dos comitês de hobbies e de selos da Venezuela ajudaram a "esfriar" as manifestações contrárias à Nixon:

Uma das ações do programa People-to-People é tirar o selo de desconfiança atribuído a este país - desconfiança estrangeira em relação a este país - e literalmente. Harry L. Lindquist, Presidente do comitê de Hobbies do Programa e editor em Nova York da revista Stamps Weekly revelou ontem que seus contatos do comitê de coleção de selos foram mobilizados para ajudar a "esfriar" o sentimento antiamericano crescente na Venezuela, por ocasião da visita do vice-Presidente Richard M. Nixon, no último mês de maio. ${ }^{249}$

Em 10 de novembro de 1956, meses após o lançamento de importantes programas como People-to-People e o Sister Cities, o primeiro diretor da USIA, Theodore Streitbert, renunciou ao seu cargo. Após três anos de gestão, Streitbert deixava como legado um modo consolidado de agir, casando a ação da USIA com o setor privado e envolvendo diferentes atores da sociedade civil. Além disso, durante o período, a agência expandiu a exibição de seus filmes em parcerias com salas comerciais ao redor do mundo, fortalecendo o VOA, expandindo as turnês artísticas e esportivas e promovendo exibições norte-americanas no exterior. 
Seis dias após o anúncio de sua renúncia, Streitbert se juntou à equipe dos irmãos Nelson e Laurance S. Rockefeller, oficialmente como assessor de negócios de família. ${ }^{250}$

Nelson A. Rockefeller, após ser o responsável pelo comitê de reorganização no início do governo Eisenhower (que entre outras coisas, propôs a criação da USIA), foi secretário do também recém-criado Departamento de saúde, educação e bem-estar de junho de 1953 a dezembro de 1954. Imediatamente após se desligar do cargo de secretário ele assume como assessor especial do Presidente Eisenhower para política externa. ${ }^{251}$

Durante o ano em que permaneceu como Assessor Especial de Política Externa de Eisenhower (até dezembro de 1955), Rockefeller criou um comitê (de 12 pessoas de diferentes setores) com a missão de preparar um plano que propusesse o perfil de uma futura estratégia psicológica para os EUA nos próximos anos da Guerra Fria.$^{252}$

O comitê de Rockefeller era coordenado por Frederick L. Anderson, general da força aérea americano, e formado por notáveis de diversas áreas, entre eles: o jovem Henry Kissinger (Harvard University), C.D. Jackson (da Time, Incorporated), Dr. Ellis A. Johnson (diretor de Departamento de Pesquisas da Johns Hopkins University), Cel. George A. Lincoln (Professor de Ciências Sociais da Academia Militar dos EUA), Dr. Paul M.A. Linebarger (da Escola Avançada de Estudos Internacionais, também da Johns Hopkins University), Stacy May (Consultor de economia), Dr. Max F. Millikan (diretor do centro de estudos internacionais do MIT/Massachusetts Institute of Techonology), Dr. Philp E. Mosely (diretor de estudos do Council on Foreign Relations), Dr. George Pettee, diretor assistente do Departamento de Pesquisas da Johns Hopkins University), Dr. Stefan T. Possony (especialista em inteligência

250 Documento 44.

251 Segundo descrição dos arquivos pessoais da família Rockefeller, em Tarrytown (NY). Disponível em <http://dimes.rockarch.org/xtf/view?docId=ead/ FA350/FA350.xml;chunk.id=ref766; brand=default\&doc.view $=$ contents $>$. Acesso em: 20 nov. 2014.

252 Documento 54. 
aérea da Força Aérea americana), eWilliam Webster (vice-Presidente executivo da New England Electric System).

Composto por empresários, acadêmicos especialistas em pesquisa, especialistas aeronáuticos, de mídia e energia, os componentes formavam uma equipe singular para pensar como os EUA deveriam agir para ganhar a batalha psicológica a longo prazo, articulando-a aos programas militar, econômico, tecnológico e ideológico.

O estudo de mais de cem páginas apresentado a Rockefeller em novembro de 1955 foi chamado de Psychological aspects of United States strategy, ${ }^{253}$ sendo o resultado de entrevistas e encontros com funcionários e diversas agências do governo, em Washington D.C. e Quantico (Virgínia). Ele partia do pressuposto que a batalha ideológica com a URSS era decisiva para o futuro do mundo como se conhecia até então. O grupo se dissolveu em dezembro de 1955.

$\mathrm{Na}$ introdução do estudo eram propostas quatro ações estratégicas que o resumiam: (1) conscientizar a população americana sobre os riscos da situação naquele momento e o que seria preciso para superá-la; (2) aumentar os gastos militares para defesa aérea americana e europeia; (3) garantir a liderança americana no mundo nos campos político, econômico e cultural, para eliminar as debilidades por onde avança o comunismo; e (4) pressionar constantemente o bloco soviético para que sejam mostradas as suas deficiências e debilidades.

Já em seu início, o estudo indicava que as antigas relações diplomáticas, realizadas antigamente a portas fechadas, não eram mais suficientes para provocar as mudanças necessárias no mundo daquele momento. 

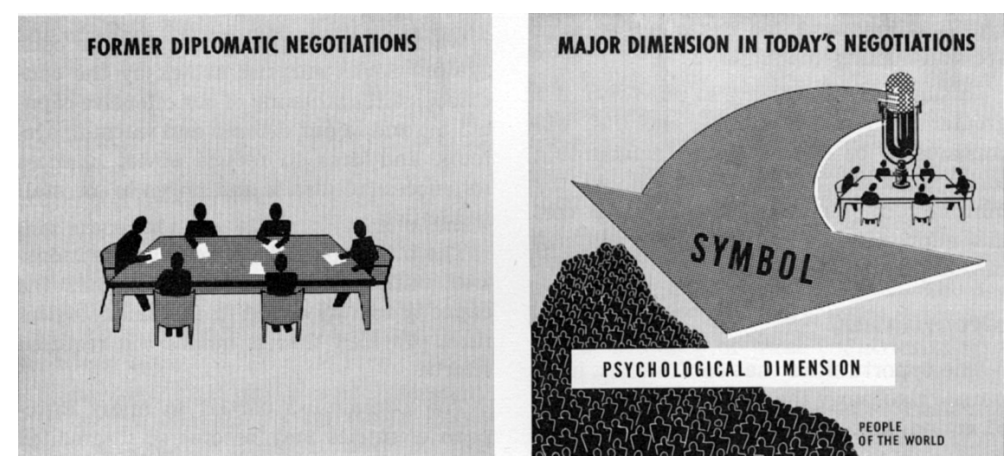

Figura 20 - A dimensão simbólica e seus desdobramentos psicológicos na nova diplomacia.

A Figura 20 mostra, à esquerda, que as negociações diplomáticas antigas ("former diplomatic negotiations") se decidiam em uma mesa com poucas pessoas. Em contraposição, nas negociações maiores daquela época, no quadro da direita, também tomadas em uma mesa, tinham que ser divulgadas eficientemente (por isso o microfone de rádio em cima da mesa), para atingir a dimensão psicológica das "pessoas do mundo", por meio da dimensão simbólica.

Era necessária, sobretudo, uma estratégia adequada para comunicação, que trabalhasse bem simbolicamente as decisões políticas das grandes potências, afetando as chamadas dimensões psicológicas dos países em geral. Além disso, o estudo também mostrava que os EUA tinham capacidade econômica de sustentar maiores gastos com a Guerra Fria do que a URSS, que a longo prazo (com uma projeção até o fim da década de 1970) perderia essa capacidade, ou causaria um colapso em sua economia. Isso tentava justificar o aumento dos gastos com o esforço militar, econômico e cultural que deveriam ser colocados em marcha para ganhar, a longo prazo, a batalha psicológica.

O que se percebe na Figura 21, "We can afford to survive", à esquerda, em cinza, é uma projeção do crescimento da economia americana até os anos 1970, e abaixo, a mancha em azul e branca apontava para os possíveis gastos necessários para ganhar a Guerra 


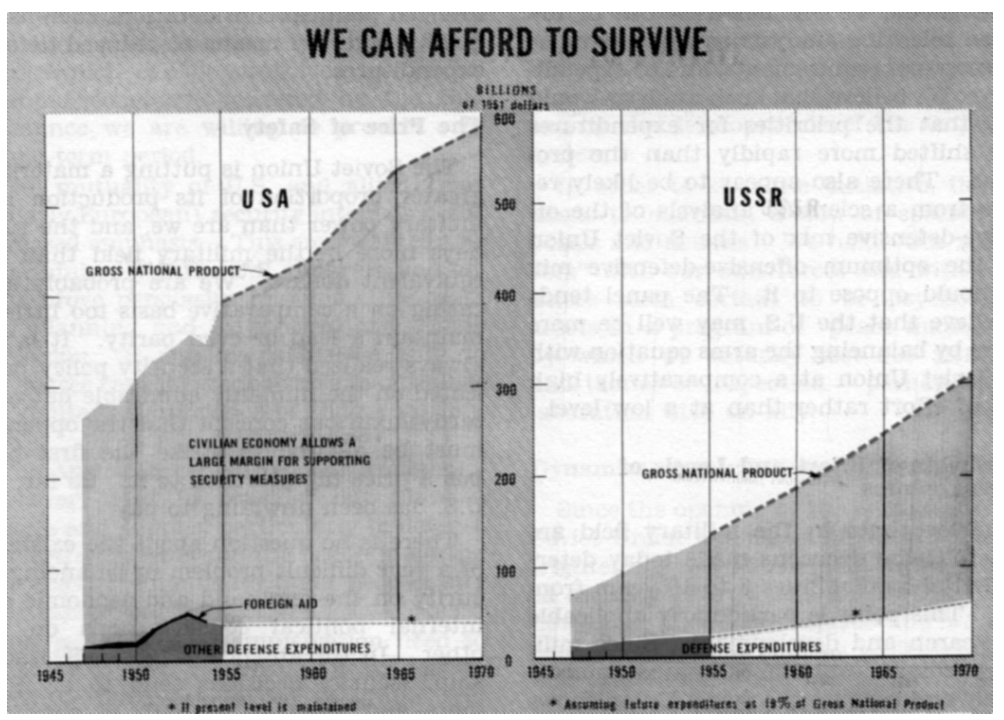

Figura 21 - Gráfico que justificava a capacidade econômica americana de sustentar um aumento de orçamento com a batalha psicológica, em comparação à menor capacidade soviética.

Fria (militares, econômicos e culturais). À direita, estava a projeção do PIB soviético no mesmo período e como os gastos com a batalha psicológica impactavam mais a sua economia, relativamente. $\mathrm{O}$ raciocínio era que, a longo prazo, os EUA conseguiriam sobreviver economicamente mais facilmente que a URSS, mantendo uma batalha psicológica com as mesmas proporções.

Segundo o relatório, o comunismo crescia em áreas subdesenvolvidas, e era nessas que os EUA (identificado no estudo como "free world") tinham que agir, de acordo com uma estratégia similar à posterior guerrilha de "foquismo", às avessas (o que eles chamavam de "free world dynamic growth"). Em cada país subdesenvolvido era necessário criar um foco de "mundo livre", que poderia estender a democracia no molde americano a toda o país e região. Como bem ilustra a imagem: 


\section{BASIC ELEMENTS for a program of Free World dynamic growth}

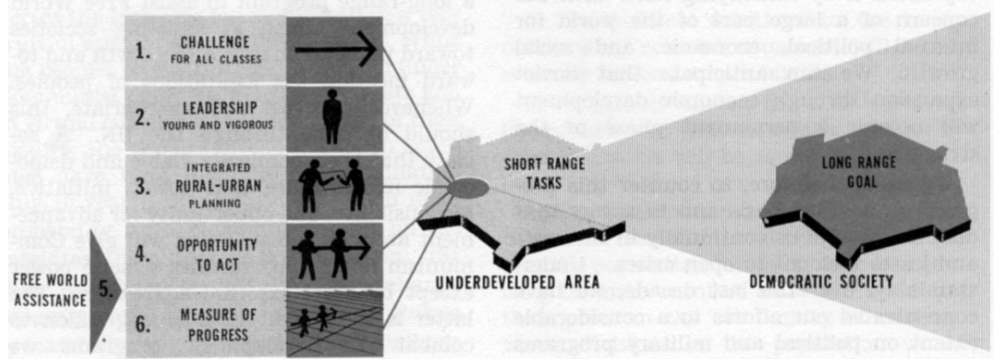

Figura 22 - Elementos básicos para o programa Free world dynamic growth.

O caso latino-americano era exemplo de sucesso da estratégia americana, citado em capítulo escrito pelo consultor em economia Stacy May, ao final do relatório. Ele mostrava que a política de cooperação econômica e técnica para o desenvolvimento aplicada no hemisfério no pós-guerra garantia democracias com um ambiente favorável para a iniciativa empresarial capitalista (e com um intenso fluxo comercial entre os países latino-americanos e os EUA). ${ }^{254}$

O tom do clima que se apresentava no relatório encomendado pelo assessor especial de política externa da Casa Branca ilustra bem o que motivava as iniciativas de informação, como a USIA. E o aspecto psicológico, resultado de políticas integradas entre os campos econômico, militar e informacional, eram centrais na política externa (e interna) dos EUA naquele momento. Daí o papel central da USIA.

A preocupação com a estratégia de informação soviética era vista como ameaça ao mundo livre, como mostra o gráfico abaixo:

Pelo que se percebe, a proposta americana pretendia combater a máquina de propaganda soviética que partiria do Agitprop soviético (Seção do partido comunista soviético para propaganda e agitação) e vinha, em várias fases, atingindo desde os círculos internacionais mais amplos até as frentes regionais, chegando em "células" mais locais como o contato pessoal (face-to-face contact). 


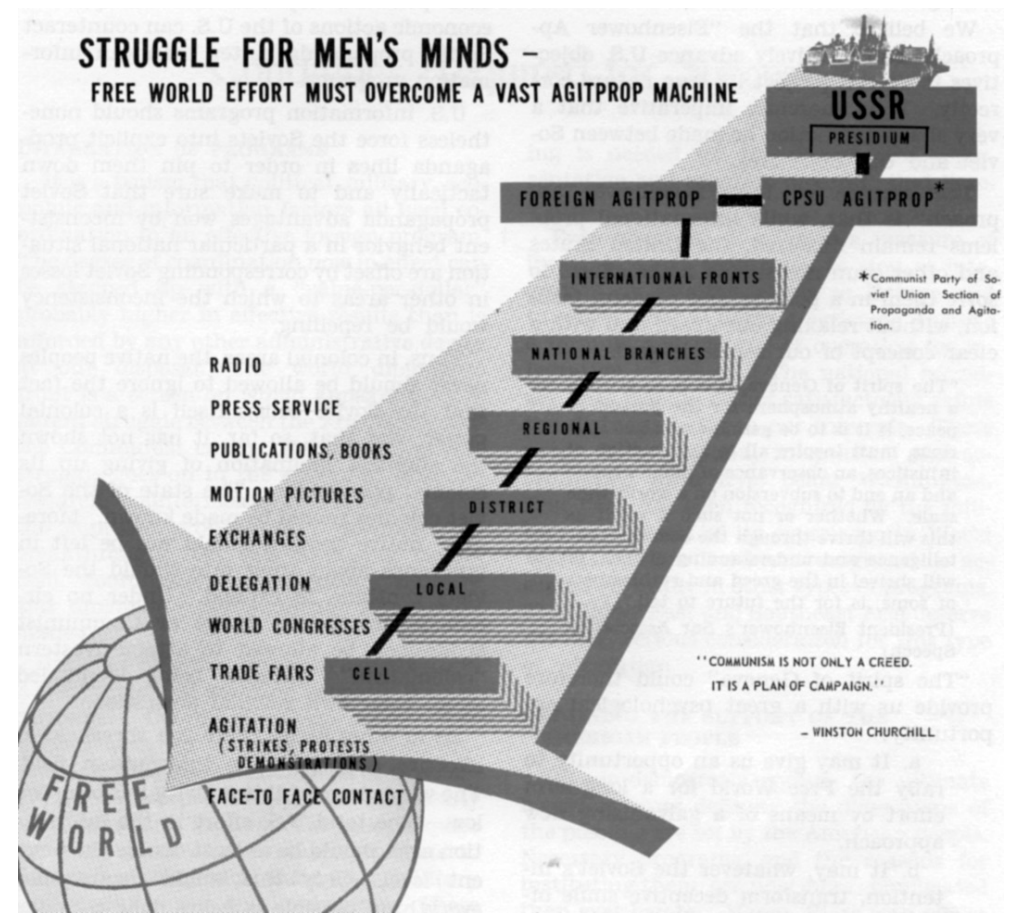

Figura 23 - A luta pelas mentes humanas - a estratégia soviética que deveria ser combatida, segundo os americanos, nos anos 1950.

Para isso, os soviéticos promoviam feiras de negócios, Congressos, delegações, intercâmbios, filmes, publicações, imprensa e rádio. Interessante notar como a interpretação americana também tomava as agitações sociais, como greves, protestos e manifestações como produtos da máquina de propaganda soviética que colocava em risco o "Mundo Livre". O gráfico era acompanhado da frase de Wiston Churchill: "Communism is not only a creed, it is a plan of campaign" (Comunismo não é só um credo, é uma estratégia).

Um outro relatório do grupo para Rockefeller, de agosto de $1955,{ }^{255}$ propunha uma estratégia unificada da política de informação do governo (Departamento de Estado, CIA e USIA) que 
trabalhassem em conjunto para o combate ideológico. Essa estratégia partiria, em primeiro lugar, da pesquisa constante, depois do treinamento, do recrutamento de pessoal, de equipamentos adequados e de material de propaganda específico para cada tarefa. A decisão em casos delicados partiria diretamente do Presidente, e em outros casos, ficaria sob a responsabilidade da USIA.

A divisão de responsabilidades proposta pelo estudo para os países comunistas era sempre no sentido de enfraquecer a vontade soviética e fortalecer personagens internos que fossem favoráveis aos EUA. Para atingir isso, o relatório propunha que a USIA fosse responsável pelas "overt forms" de propaganda (com a disseminação oficial da informação americana) e a CIA seria responsável pelas "covert forms" (contrainformação e espionagem). ${ }^{256}$

O Departamento de Defesa ficaria responsável pela propaganda "tática", entre frentes de defesa inimiga e para o próprio pessoal das Forças Armadas americanas. Para as ações de informação interna nos EUA, o órgão responsável seria o Office of Non-military Warfare. ${ }^{257}$

Para os países neutros e amigos dos EUA (ou onde os EUA mantinham bases militares), a USIA seria responsável por todas as políticas de propaganda e informação. É importante salientar que no relatório eram citadas e diferenciadas as ações de informação, com o sentido de notícia vinculada oficialmente pelo governo e propaganda como veiculação da imagem positiva de maneira não necessariamente oficial e em diferentes formatos..$^{258}$

As recomendações feitas pelo estudo encomendado pela Casa Branca, apesar de não incluírem a USIA na sua elaboração e não determinarem a forma de aplicação de seus apontamentos, ${ }^{259}$ desenharam o modo de procedimento da USIA durante os anos $1950 \mathrm{e}$ 1960, tanto no uso das pesquisas e instrumentos de propaganda e

256 Documento 55.

257 Documento 55.

258 Documento 55.

259 Dizard Jr. (2004, p.68) mostra que a USIA não participou do processo de elaboração do grupo de Rockefeller, patrocinado em grande parte com fundos próprios de Rockefeller e da CIA. 
informação, como das parcerias com CIA, Departamento de Estado e de Defesa.

Com a saída de Streitbert para a assessoria dos irmãos Rockefeller, o Presidente americano demorou pouco menos de um mês para decidir-se sobre seu substituto na direção da USIA.

Ao passar o verão de 1956 se recuperando de uma cirurgia abdominal, Eisenhower lê o livro A Republican look at his party, de Arthur Larson, advogado de Milwaukee e chefe do Departamento de Direito da Universidade de Pittsburgh, que havia sido nomeado under secretary no Ministério do Trabalho em 1954. Segundo reportagem do New York Times, ${ }^{260}$ Eisenhower se encantou com o livro, que segundo ele refletia a sua visão do que o republicanismo moderno deveria ser.

Em 18 dezembro de 1956 Arthur Larson assume como o novo diretor da USIA. Sua breve gestão na direção da Agência, até 27 de outubro de 1957, foi marcada muito mais pelas discussões acaloradas com os líderes democratas no Congresso, do que em alguma marca específica de sua gestão. Um de seus maiores críticos foi o senador Lyndon B. Johnson, que liderou um corte de orçamento de 33\% para o ano de 1957: US\$ 96 milhões. Cerca de US\$ 13 milhões a menos do que em 1956. ${ }^{261}$

Com pouco orçamento e dificuldades em lidar com a oposição política, Larson foi transferido para a Casa Branca como assessor especial do Presidente para "projetos especiais, em Relações Internacionais, referentes aos programas de informação americanos e esforços soviéticos de propaganda" ${ }^{262} \mathrm{Na}$ ocasião, o Secretário de Imprensa da presidência, James Hagerty, comentou que Larson iria assumir as tarefas desse tema específico, "among other things". Como se percebe, mesmo depois da assessoria especial de Rockefeller e das recomendações de seu comitê, Eisenhower continuou sendo um dos únicos Presidentes com o gosto em tratar do tema da

260 De 17 de outubro de 1957, intitulada "Envoy to succeed Larson at USIA".

261 Idem.

262 Documento 24. 
propaganda e das políticas "psicológicas" pessoalmente. Segundo Bogart (1995, p.xxix):

Às três da madrugada o Presidente pode ter uma boa ideia e liga para o Diretor de Segurança Nacional ou o Secretário de Estado, mas ele nunca liga para o diretor da USIA. Nenhum Presidente, com a possível exceção de Dwight Eisenhower, considerou o diretor da USIA importante.

Após o curto e turbulento período da USIA com Larson, Eisenhower resolveu nomear alguém com reconhecida experiência na área, que assumisse a direção da USIA e levasse de maneira suave e eficiente o trabalho que deveria ser feito. Para isso, trouxe de volta do importante posto de embaixador na Grécia ${ }^{263}$ (que havia tido um ativo papel na crise de Suez ${ }^{264}$ e diplomata desde os anos 1930, o ex-Assistant Secretary of State for Public Affairs, George Venable Allen.

Allen era diplomata respeitado e tinha bom trânsito entre Republicanos e Democratas, principalmente pela sua importante passagem anterior como Assistant Secretary, de 1948 a 1950. Período esse da transição das políticas no pós-guerra e, portanto, Allen já possuía experiência na gestão doVOA, nas bibliotecas no exterior e em todos os temas que envolviam as políticas culturais e de informação. $\mathrm{O}$ próprio Allen brincou em relação a sua volta: "Pelo menos ninguém pode dizer que eu não sei direito onde estou me metendo". ${ }^{265}$

Em 15 de novembro de 1957, Allen assumiu como diretor da USIA, cargo que ocupou até $1^{\circ}$ de dezembro de 1960, já no final do segundo mandato de Eisenhower. Allen, que tinha mestrado em Harvard, com passagens em cursos na Johns Hopkins University, ${ }^{266}$ dizia em seus discursos e artigos que a política internacional era diferente no pós $2^{\text {a }}$ Guerra.

263 Documento 37.

264 Nichols (2011, p.122), estudo importante sobre Eisenhower e a crise de Suez, em 1956.

265 Documento 24.

266 Documento 24. 
THE NEW YORK TIMES, THURSDAY, OCTOBER 17, 1957

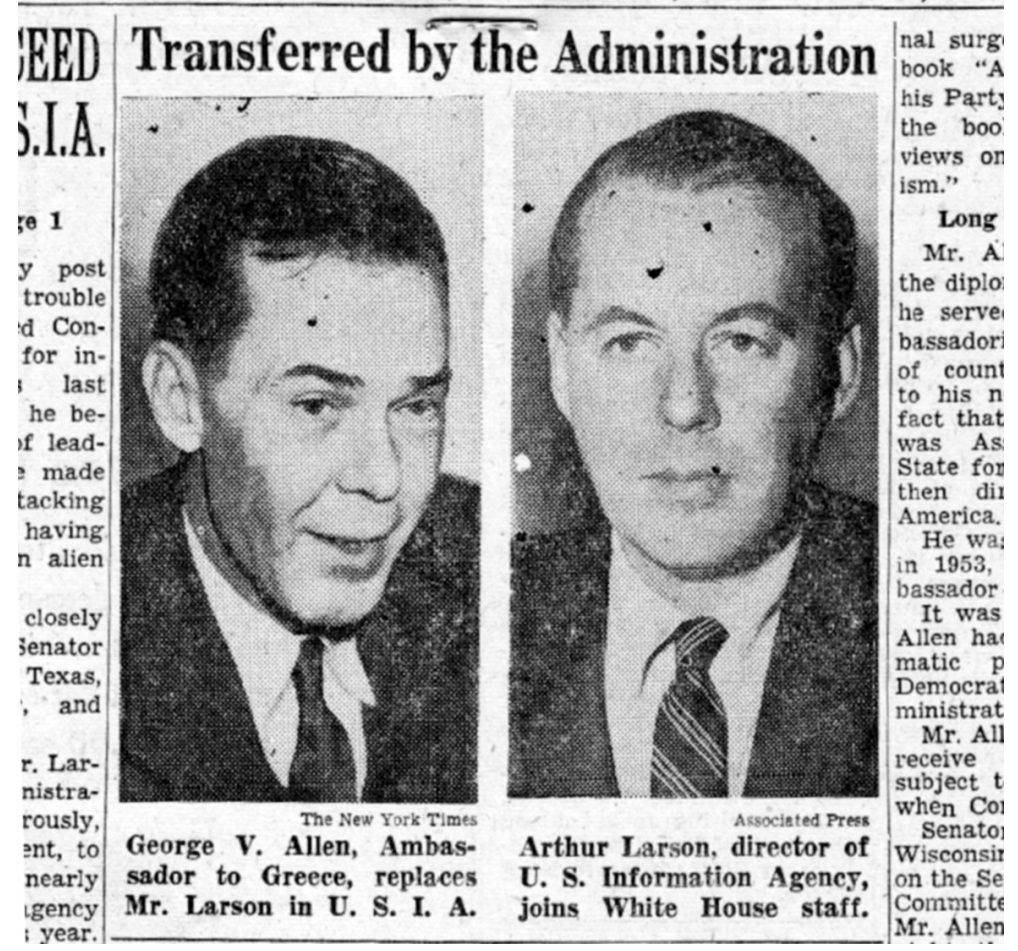

Figura 24 - Sai Larson, que foi diretor por curto período e entra Allen, nome de consenso para a direção da USIA.

Segundo ele, a partir da criação da $\mathrm{ONU}$ as pessoas, e não mais os Estados, começaram a ser os protagonistas internacionais, sempre se referindo ao preâmbulo da carta da ONU, "We the peoples of the United Nations", em comparação com o mesmo princípio presente na Declaração da Independência Americana, que começava com "nós, o povo, ... [movidos por] um decente respeito pelas opiniões da humanidade...".267

267 Documento 37: artigo de outubro de 1958 à revista “Think”, republicada também pela USIA. 
O discurso de Allen já mostrava a sua prioridade de gestão na USIA do governo Eisenhower, isto é, o aprofundamento do programa People-to-People como estratégia de mobilização e convencimento da opinião pública internacional. Para os países das "cortinas de ferro e de bambu", nos quais os programas de informação americanas encontravam dificuldade maior de acesso, a estratégia era entrar pelas ondas do rádio. Quase 70\% das transmissões do VOA, durante os anos Allen, eram dedicados às áreas adversárias. ${ }^{268} \mathrm{E}$, segundo relatório interno de 1958, ${ }^{269}$ o bloco soviético gastava anualmente mais do que o orçamento daquele ano (US\$ 98 milhões) para tentar obstruir o sinal do VOA em suas fronteiras.

O sucesso dos programas do VOA na URSS era tanto que centenas de cartas de ouvintes dos blocos comunistas chegavam todo mês em sua sede em Washington. Uma delas, escrita por uma jovem tcheca dizia que "[o VOA me proporcionou] que ficasse familiarizada com o desenvolvimento da arte e do espírito da nação americana, com todas as suas esperançosas raízes de pensamento". ${ }^{270}$

Além do VOA, a USIA continuou também aprofundando a sua política para difusão de filmes. Em 1959, mais de 210 bibliotecas exibiam filmes produzidos pela agência, tanto para grandes audiências, quanto para grupos seletos. Naquele ano, cerca de meio bilhão de pessoas assistiram a filmes da USIA em 80 países, em 41 línguas. $\mathrm{Na}$ África, por exemplo, a USIA produzia um noticiário de sucesso chamado Today, que mostrava as dificuldades das repúblicas recém-independentes, e as comparava com a situação da mesma área nos EUA. ${ }^{271}$

Um dos destaques dos filmes da USIA era a série de filmes sobre o Atoms for Peace, uma das grandes bandeiras internacionais de Eisenhower, que mostrava os múltiplos usos pacíficos da energia

268 Documento 37.

269 Documento 37.

270 Documento 37.

271 Documento 51: "The overseas film program, U.S Information Agency", 1959. 
atômica. Mais de 50 filmes sobre o tema foram produzidos pela agência, entre 1953 e $1959 .{ }^{272}$

Outro tipo de filmes feito pela USIA eram os documentários que denunciavam as mazelas dos países comunistas, como a série sobre a repressão violenta aos movimentos na Hungria, em 1956. Documentários como Hungarian fight for freedom, A nation in torment e The death of Imre Nagy contavam sobre a violência usada pela "mão de ferro soviética". Now we are free descrevia a fuga de húngaros durante a revolta, e Sanctuary mostrava a vida de um casal húngaro refugiado nos EUA. ${ }^{273}$

A USIA também produzia documentários locais, contando a história da região e relacionando-a sempre aos EUA. Mais de seis mil equipamentos de som e 350 unidades locais de projeção foram usados para alcançar locais que não tinham bibliotecas ou centros binacionais. Ainda, na década de 1950 mais de 1.300 filmes da USIA foram exibidos também em canais de TV comerciais ao redor do mundo. ${ }^{274}$

Além do aprofundamento das políticas de rádio e filmes, que visava atingir, a curto prazo, regiões não contempladas com os serviços de bibliotecas e centros binacionais, Allen continuou dando a mesma ênfase que deu em sua gestão no Departamento de Estado na década de 1940: a consolidação da influência americana no mundo a longo prazo.

Em 1958, quando da aprovação do orçamento para a USIA, no Congresso, Allen afirmou que:

Nossa principal preocupação precisa ser a construção de um estudo para o estabelecimento de uma base sólida de confiança entre os povos do mundo, na integridade e boa vontade do povo americano, principalmente com iniciativas de longo prazo; como as bibliotecas e programas de livros, por meio dos intercâmbios culturais, 
por meio dos esforços do people-to-people, e colocando as notícias de cada dia em uma perspectiva favorável. ${ }^{275}$

Pode-se perceber esse esforço nas políticas de doação de livros (subsidiados) do programa People-to-People (em seu comitê Fraternal Organizations). Por US\$ 40 dólares uma pessoa poderia doar 99 livros (pré-selecionados), para uma comunidade pelo mundo. Os livros eram das áreas de história, filosofia, biografias, educação, artes, ciências, e literatura (antologias, poesias e ficção). Entre outros, reuniam biografias de Lincoln, história da América, poetas, artistas e escritores americanos, sempre enfatizando características positivas da América.

Por um preço acessível, o cidadão comum americano poderia dar a sua contribuição ao plano de Eisenhower de aproximar o mundo ao modo de vida do americano médio. Com uma contribuição, qualquer pessoa do mundo poderia ter a mesma estante que os americanos tinham. O folheto que incentivava a doação de livros, aparentemente uma iniciativa da sociedade civil "fraterna", não explicava, contudo, quem selecionava os títulos e subsidiava as despesas de produção, tradução e distribuição dos livros ao redor do mundo.

Uma reportagem publicada nos jornais The Cincinnati Post e Times-Star (em 13 de maio de 1959) explicava, em partes, como funcionava este tipo de projeto. Com o título "Here's Your Chance to Help Latin American Neighbors: ...making friends for America through books", a notícia descrevia o Books Abroad Week, do programa People-to-People, de doação de livros para a América do Sul. ${ }^{276}$

No âmbito nacional, quem financiava especificamente esse projeto era a empresa "Life Insurance" e, regionalmente, quem apoiava eram as empresas de seguro Union Central, Ohio National, a Inter-Ocean e a Western and Southern Life Insurance Companies. A campanha era promovida publicamente em Cincinnati

275 Documento 37: George V. Allen, Hearings before the Subcommittee of the Committee on Appropriations United States Senate, May 27, 1958.

276 Documento 37: George V. Allen, Hearings before the Subcommittee of the Committee on Appropriations United States Senate, May 27, 1958. 


\section{"A Fratermal Hookshelfo" overseas}

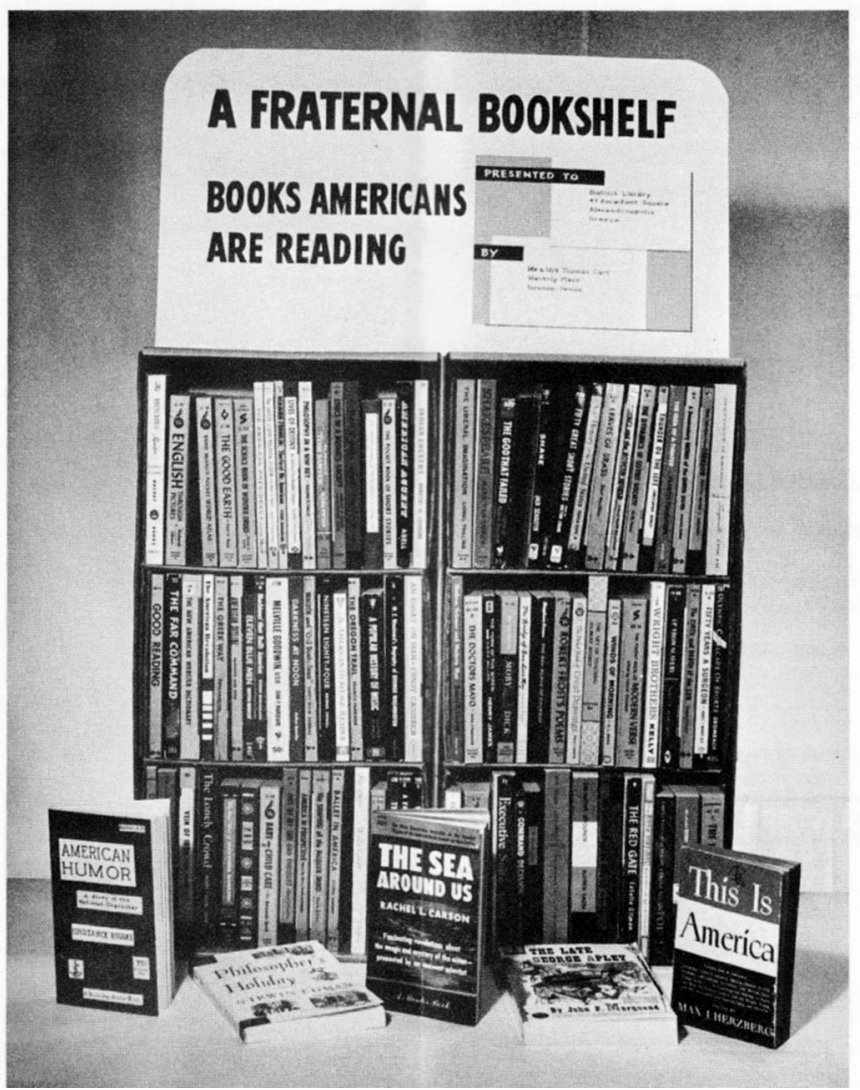

Figura 25 - A Fraternal Bookshelf: por 40 dólares, 99 livros selecionados pelo People-to-People.

pelo presidente da Union Central e pelo gerente da biblioteca pública local.

A proposta do Books Abroad Week pretendia arrecadar 25 mil livros de capa dura, que fossem especificamente de autores americanos, biografias de americanos, viagem nos EUA, artes, engenharia e ciências, e que tivessem sido publicados depois da $2^{a}$ Guerra. Os livros seriam enviados a escolas, bibliotecas e centros educacionais em 
Honduras, no Chile na Universidade dos Andes, e na Colômbia. A matéria ainda destacava a importância da iniciativa em contra-atacar a propaganda comunista que ameaçava o hemisfério. ${ }^{277}$

De 1953 até o final da administração Eisenhower, em 20 de janeiro de 1961, a USIA auxiliou editoras americanas e estrangeiras a traduzir, publicar e distribuir mais de 44 milhões de cópias de 4.400 diferentes títulos de autores americanos, em 50 idiomas diferentes. ${ }^{278}$ Além disso, mais de 100 mil livros usados foram coletados e transportados pelo Book Committee, do People-to-People, com auxílio da USIA.

A cooperação educacional da USIA também previa a aproximação e a filiação entre universidades americanas, e outras, por meio do seu Departamento de cooperação privada (Office of Private Cooperation of the United States Information Agency). ${ }^{279} \mathrm{De}$ 1955, quando o programa de cooperação universitária no âmbito do People-to-People começou, em 1959, mais de 30 convênios foram assinados com universidades do Oriente Médio, da Ásia, da Europa e da América Latina. Allen confirmava a importância dessa aproximação educacional:

A atuação cultural de seu país ao redor do mundo requer uma representação mais ampla possível, e será extremamente benéfico se a educação superior americana continuar a expandir sua presença nesse campo [...] Os educadores e instituições educacionais de americanos podem ajudar tremendamente no trabalho que a United States Information Agency está tentando fazer. Muitos deles estão ajudando, mas eu gostaria de ver essa faceta de nosso programa se expandindo enormemente. ${ }^{280}$

277 Idem.

278 Documento 56.

279 Documento 52: "The College and University Affiliation Program - To Encourage International Understanding Through Educational Institutions", 1959.

280 Documento 52: "The College and University Affiliation Program - To Encourage International Understanding Through Educational Institutions", 1959. 
Uma das grandes contribuições de Allen foi a relativa melhora da relação quase sempre conflituosa com o Congresso (Bogart, 1995, p.26, 28). Isso pode ser atribuído à sua história e credibilidade com os dois partidos, uma vez que já tinha trabalhado em postos de direção da informação tanto em governos Democratas quanto Republicanos.

A tão dura aprovação anual dos orçamentos da USIA ${ }^{281}$ foi facilitada, com o diplomata Allen, por aliar o discurso anticomunista ${ }^{282}$ à apresentação de uma política de informação que refletisse a democracia americana, por meio de seus inúmeros artigos, discursos, palestras e manifestações públicas em TVs e rádios, divulgando a importância do trabalho da agência nos EUA.

Alguns estudiosos da USIA, como Bogart (1995, p.33), criticavam a constante prestação de contas e o detalhamento das ações de informação no exterior na mídia americana, como se isso enfraquecesse o processo de "sedução" da agência:

A preocupação nacional com a mídia de massa inibe o pensamento voltado para alvos e objetivos específicos. A impaciência causa pressa injustificada na produção do trabalho da USIA. Isso faz com que se exponha uma estratégia que deveria se manter secreta.... Eu não acho que você deveria publicizar a sua estratégia de propaganda. Eu sou antiquado. Fazer um artigo sobre qualquer coisa que exponha tão explicitamente nossos esforços em manipular as coisas, para criar a aparência de egoísmo entre nós e outros povos! É como descrever sua técnica de sedução e como você faz parecer galanteio, na presença da garota que você está seduzindo.

281 Reich (1996, p.625, 630). A luta pelo aumento dos orçamentos das atividades de informação no exterior foram constantes durante o governo Eisenhower. Rockefeller (com apoio de Nixon) foi um dos que sempre requisitaram aumento do orçamento da USIA, nas discussões internas da Casa Branca, porém nem sempre com sucesso.

282 Alguns funcionários da USIA descreviam o anti-comunismo como estratégia mais fácil para aumentar o orçamento da agência no Congresso. Bogart (1995, p.xxviii). 
A promoção das atividades de informação como estratégicas para os EUA surtiram efeito, como pôde se perceber pelo grande número de atividades do programa People-to-People, internamente, e pelo massivo apoio privado americano. O Office of Private Cooperation da USIA, então localizado em Washington DC (no suntuoso Walker-Johnson Building, da New York Avenue), além de uma filial em Chicago, centralizou toda a ajuda das empresas e fundações americanas. $^{283}$

Já durante o primeiro ano de funcionamento da USIA, em 1953, a USIA contou com 168 organizações privadas, sendo 111 empresas, 20 organizações sem fins lucrativos, 7 comunidades, 15 grupos artísticos, 3 escolas, 7 Departamentos Governamentais e 5 fraternidades. ${ }^{284}$

A American Express, a American President Lines, a Pan American Airlines, e a American Automobile Association forneciam transportes para pessoas e materiais; a Walt Disney, a Home Book Publishers, a Union Pacific, a Flewelling and Moody (arquitetos) e American Institute of Architects colaboravam com materiais e idealização de mobiliários e materiais para feiras e exposições; a Wilson Sporting Goods Company fornecia materiais esportivos para exposições sobre esportes e para as turnês de esportistas no exterior; a Eastman Kodak Company fornecia fotos dos EUA para as exposições; 21 jornais colaboravam com programas de intercâmbio de jornalistas estrangeiros, em cada redação, durante períodos de 3 a 6 meses (entre eles o San Francisco Chronicle, o Daily Press, o Newark News, o Chicago Sun-Times, entre outros); a General Electric X-Ray Divisions fornecia aparelhos, a Swift and Company fornecia revistas para exposições; os Rotary Clubs distribuíam os materiais entre seus membros mundo afora; a Barclay Company, a Caterpillar Tractor Company; a Life International, o Reader's Digest, todos contribuíam, de alguma forma, para as atividades da USIA no exterior. ${ }^{285}$

283 Documento 56: relatório interno para USIA, do Office of Private Corporation. 284 Idem.

285 Idem. 
As fundações privadas também colaboravam com atividades e com financiamento das atividades. A Ford Foundation oferecia US\$ 35 mil dólares por ano para seu programa International Friendship League, de acordo com instruções da USIA. A Rockefeller Foundation doava US\$ 400 mil dólares anuais para bolsas de novos compositores estrangeiros, que tocavam suas músicas pela Louisville Orchestra, transmitidas pela CBS. ${ }^{286}$

O aumento das atividades de informação, por meio das alianças com empresas e sociedade civil, foram indiscutivelmente fruto da ênfase de Ike para uma nova política de informação no exterior, com a disposição pessoal do Presidente e do vice-Presidente americanos em viagens ao redor do mundo (inclusive no Brasil, como se verá no terceiro capítulo).

Mesmo com a atenção pessoal do Presidente, a política externa teve altos e baixos durante, principalmente, crises e conflitos nascidos das reconfigurações e reacomodações regionais do pós-guerra (como as crises de Suez, na Guatemala, no Vietnã e, sobretudo, em Cuba), que fugiram às piores expectativas do Presidente americano (Sellers; May; McMillen, 1990, p.399).

Essas crises poderiam ser evitáveis, na maioria dos casos, se não fossem lidas como ameaças comunistas e sim como movimentos nacionalistas. Para Sellers; May; Mcmillen, ${ }^{287}$ por exemplo, a posição do governo Eisenhower no Vietnã (em 1954, na oposição à revolta dos locais contra os franceses e em 1956, com a intervenção da CIA na eleição que Ho Chi Min ganharia), poderia ser positiva se os EUA apoiassem e cooptassem o governo eleito a seu favor, tendo um país independente do bloco soviético na região, como era a Iugoslávia de Tito. Para os autores, o governo Eisenhower deixou um resultado negativo na sua política externa: "Na melhor das hipóteses, Eisenhower deixou um legado confuso. Por motivos na maior parte além do controle, declinou o poder relativo da América no mundo". ${ }^{288}$

286 Idem.

287 Idem, p.402.

288 Idem, p.381. 
Internamente, por outro lado, o governo Eisenhower foi marcado pelas agitações sociais dos movimentos de direitos civis liderados por Martin Luther King e pela aprovação das primeiras leis de direitos civis em 1957 e 1960. Na economia, os EUA viviam seus anos dourados desde o pós-guerra e o governo Ike se caracterizou pela expansão da economia, o baby boom, o crescimento das estradas e crescimento do crédito que financiou milhões de novas casas nos subúrbios americanos, todas elas equipadas com eletrodomésticos de última geração. Internamente, o sonho americano se realizava para grande parte da imensa classe média do país, mas a vontade por maior inclusão das minorias e novas demandas aparecia latente. ${ }^{289}$

O saldo dessa ambivalente equação foi refletido na eleição da nova geração de republicanos e democratas: Nixon, então vice de Ike, contra o jovem democrata John F. Kennedy. Por margem mínima de votos vencem as propostas reformadoras de JFK, que não teve a mesma sorte na eleição do Congresso, com pequena vantagem da maioria republicana.

No debate político sobre o rumo que as políticas de informação deveriam tomar, as diferentes concepções continuavam. JFK, que durante as campanhas criticou duramente a política de informação de Eisenhower por deteriorar a imagem americana no exterior (Pells, 1997, p.87), tentaria reestruturar a USIA em um momento de forte polarização interna.

Por um lado, o discurso republicano mais radicalmente anticomunista, pregava uma política de informação que usasse todos os meios disponíveis para arrasar definitivamente com a propaganda soviética. Por outro lado, o discurso democrata, que pedia uma política de informação que expressasse a democracia americana no que ela tinha de melhor, usando a verdade dos fatos como arma vencedora.

Esse conflito de visões sobre o trabalho da USIA nos anos 1950, continuou perseguindo os responsáveis pela agência na década de 1960, também no novo governo Kennedy. Como disse um 
funcionário em pesquisa interna sobre a política de informação, o dilema seguia constante:

E aí voltamos à expectativa do povo americano. Eles querem uma agência de propaganda que seja uma verdadeira agência de propaganda, um vigarista levando a melhor com as pessoas e movendo a concha mais rápido do que o estrangeiro possa ver a mão, uma abordagem "à la" Goebbels. Por outro lado, nós temos repugnância e desconfiança do envenenamento das linhas de pensamento, e nós queremos ser honestos, tipo de agência do American-boy direito. Nós queremos um maquiavélico, com olhar malicioso, impassível e queremos também, ao mesmo tempo, o tipo Poliana. ${ }^{290}$

\section{Kennedy, Murrow e a reestruturação da USIA}

É muito difícil medir o sucesso na nossa área [...] nenhum computador clica, nenhuma caixa registradora toca quando um homem muda de ideia ou opta pela liberdade. E sobretudo, é o que fazemos - não o que dizemos - que tem o maior impacto no exterior. A USIA pode explicar, interpretar, esclarecer, resumir e projetar, mas não podemos mudar o imutável ou o que não foi feito. [...] persuasão é um dos mais importantes instrumentos do poder americano. Nosso arsenal de persuasão precisa estar tão pronto quanto nosso arsenal nuclear, e utilizado como nunca. ${ }^{291}$

Edward Murrow, 1963

John F. Kennedy assumiu a presidência em 20 de janeiro de 1961, com o compromisso de aprofundar o acesso aos direitos civis aos seus nacionais e continuar o crescimento econômico, com maior

290 Entrevista realizada para pesquisa de Bogart (1995, p.34).

291 Documento 29. 
diálogo com os movimentos sociais. Na política externa, propunha recolocar os EUA com espaço de prestígio no mundo, principalmente recuperando sua imagem como modelo de democracia a ser seguido, em contraposição ao comunismo, que se estendia tanto na Europa, quanto na Ásia, e com Cuba, no próprio continente americano.

A política de informação, portanto, se mostrava indispensável. Como se assistiu nos anos Eisenhower, os poucos anos de Kennedy mostrariam o auge da USIA como agência estratégica para a política externa americana.

Durante a campanha, JFK se comprometeu em nomear os melhores quadros técnicos como seus ministros, independentemente de interesses políticos e partidários. Para a USIA, alguns nomes foram pensados e consultados pelo Presidente recém empossado. Um dos nomes cogitados foi o jornalista ex-assessor de imprensa de Roosevelt e Truman, o sulista Jonathan Daniels, mas não chegou a ser convidado. O primeiro nome a ser consultado por Kennedy foi o de Frank Staton, Presidente da Columbia Broadcasting System (CBS) e responsável pelo comitê de Rádio e TV do programa People-to-People, ${ }^{292}$ porém esse negou o convite. ${ }^{293}$

O seguinte na lista era o famoso radialista e apresentador de TV da CBS, o jornalista Edward R. Murrow, uma das escolhas favoritas pelo papel importante que teve em seu trabalho como radialista na $2^{a}$ Guerra. Murrow possuía um dos principais quadros do VOA em transmissões diretamente da Inglaterra, e, nos anos 1950, na crítica ao macarthismo e à caça às bruxas levada a cabo pelos republicanos mais radicais, atuando como âncora do programa de reportagens See it Now, da CBS. ${ }^{294}$ Apesar de não conhecer Murrow muito bem,

292 Para responsáveis por comitês do programa People-to-People, Documento 56.

293 Documento 48: relato de Ted Sorensen, assessor pessoal de Kennedy, que colaborava com a maioria de seus discursos. O irmão de Ted, Thomas Sorensen, que foi diretor de Policy and Plans na USIA de Murrow, também é autor de um livro importante sobre a política de informação no período Kennedy: The world war: the story of American propaganda, de 1968.

294 O filme "Good Night, Good Luck", de 2005, dirigido por George Clooney, mostra o papel importante que Murrow, como um dos jornalistas mais 
Kennedy o considerava, pela sua credibilidade, um dos mais capacitados quadros para a mudar a imagem da USIA. ${ }^{295}$

Alguns dias após a posse, Murrow foi convidado por Kennedy, aceitando receber um salário anual de US\$ 21 mil dólares, 90\% a menos do que ganhava como jornalista. Segundo Murrow, por acreditar na capacidade de JFK, aceitou o desafio: "Eu só pensei que se esse jovem homem não puder fazer, ninguém pode, e se ele quer que eu ajude, eu tenho a obrigação de fazer. ...Eu critiquei burocratas durante toda minha vida adulta, agora era minha hora de tentar". ${ }^{296}$

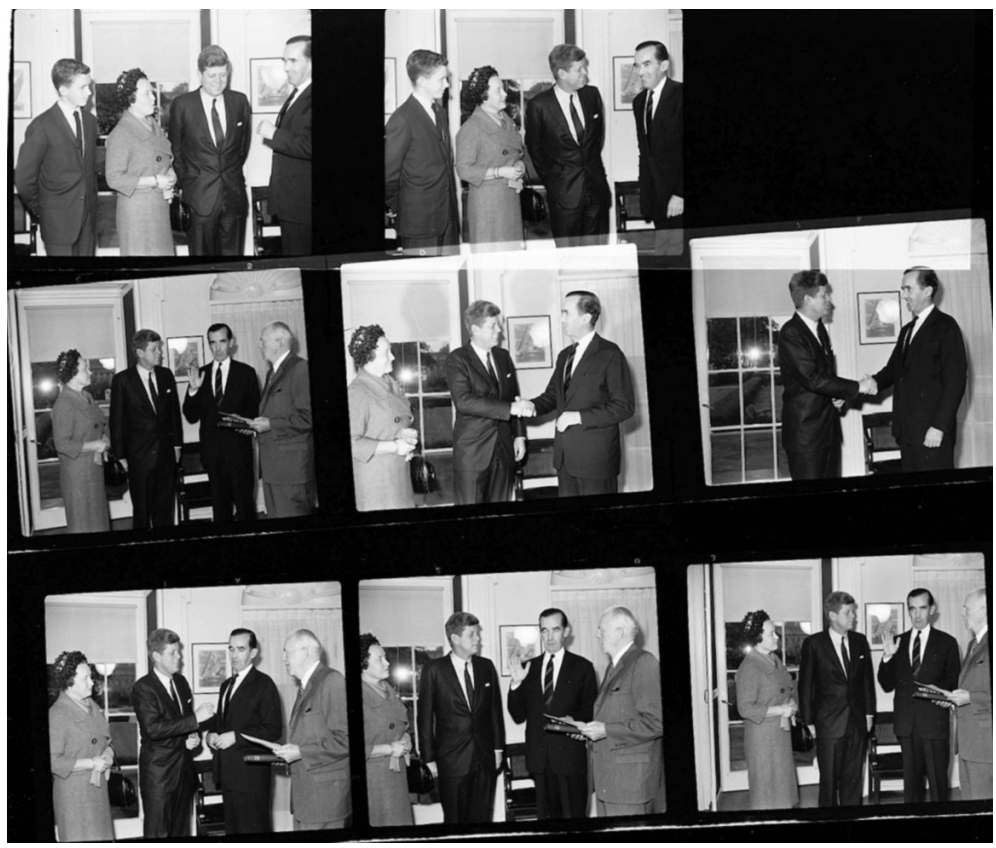

Figura 26 - Sequência de fotos da posse de Murrow, com o Presidente Kennedy, em 15 de março de 1961.

respeitados do país, teve na crítica ao radicalismo anticomunista de MacCarthy nos anos 1950.

295 Documento 48.

296 Documento 48. 
A nomeação de Murrow trouxe automaticamente uma boa repercussão interna, ${ }^{297}$ e de imediato JFK respondia ao seu discurso de campanha de fortalecer a imagem positiva dos EUA no exterior e colocá-la com um papel mais central no processo de elaboração da política externa americana. Segundo Pells (1997, p.90), a sua estrelada assessoria também trazia consigo a credibilidade da informação e glamour:

Murrow trouxe glamour para uma agência que não estava acostumada ao reconhecimento ou respeito. Ao longo de sua passagem de três anos, de 1961 a 1963, Murrow personificou a USIA; ele foi o símbolo com quem todo mundo se identificava. $\mathrm{O}$ pessoal da agência não tinha mais que explicar o que fazia; bastava dizer "Eu trabalho para o Ed Murrow". Em troca, Kennedy ofereceu a Murrow o acesso ao poder, uma cadeira na mesa onde as decisões eram tomadas, influência na formulação da política que os diretores anteriores da USIA nunca tinham tido. Como chefe da agência que supostamente sabia o que os estrangeiros estavam pensando, Murrow poderia ter se tornado o principal assessor de Kennedy sobre as consequências psicológicas e propagandísticas das estratégias diplomáticas americanas. Ele seria, portanto, um participante ativo em encontros do Conselho de Segurança Nacional, contribuindo com sua opinião quando fosse importante. Ainda mais, os principais assessores de Murrow tinham suas próprias ligações com a Casa Branca. Thomas Sorensen, um veterano da USIA, era irmão de Ted Sorensen, principal redator dos discursos de Kennedy. Donald Wilson, um ex-correspondente das revistas Life e Time, tinha trabalhado na campanha presidencial de Kennedy em 1960 e era amigo de Robert Kennedy. Então a USIA não parecia mais ser uma agência periférica, somente explicando a política externa americana

297 Elder (1968, p.42). O prestígio de Murrow se devia pela sua vasta lista de serviços na área da comunicação. Entre outros cargos, Murrow havia trabalhado na CBS durante 25 anos, como membro do Conselho, diretor de relações públicas e vice-Presidente. 
para o mundo. Agora estava no (ou perto do) centro do governo, com Murrow, um membro valorizado na equipe de Kennedy.

As novas diretrizes de Kennedy para a política da USIA partia de estudos que o recém-eleito Presidente tinha encomendado para alguns de seus assessores mais próximos, em dezembro de 1960, antes de ser empossado. Quem coordenou esses estudos sobre política externa (com temas como África, desarmamento, política externa econômica, operações do Departamento de Estado e USIA) foi o seu assessor George W. Ball, que viria ser o seu "under secretary of state for economic and agricultural affairs". ${ }^{298}$

Para os estudos sobre USIA foram convidados Lloyd Free, ex-funcionário de informação do Departamento de Estado, ex-PAO na Itália e diretor do Institute for International Social Research ${ }^{299}$; Thomas Sorensen, jornalista e irmão de Ted Sorensen (assessor direto de Kennedy) e futuro diretor de Plans \& Policies da USIA; e o também jornalista da revista Time, Donald M. Wilson (Elder, 1968, p.42), que trabalhou na campanha e como diretor da transição na agência durante sete semanas. Após a posse de Murrow, Wilson foi o deputy director da USIA durante os anos JFK, como principal gestor dos serviços internos da agência. ${ }^{300}$

Os estudos apontavam alguns temas comuns, como mudanças operacionais e, principalmente, de visão política sobre o trabalho da agência. O estudo de Wilson, por exemplo, recomendava: maior ênfase no continente africano, principalmente por meio do ensino do inglês e da cooptação de estudantes africanos, que muitas vezes optavam por estudos na Europa; a melhora das relações com América Latina, com foco especial nos estudantes e movimentos sindicais; e a criação de um programa que consiga enfatizar os avanços tecnológicos e científicos dos EUA nos últimos anos.

298 Documento 29: "1960: Free-Sorensen-Wilson did studies of USIA for Kennedy".

299 Lloyd Free também era editor do periódico Public Opinion Quarterly (Documento 29).

300 Documento 29: "1960: Free-Sorensen-Wilson did studies of USIA for Kennedy". 
Além disso, Wilson sugeria por maior e melhor recrutamento e treinamento dos funcionários da USIA, e maior participação pessoal do Presidente como ator principal das ações de informação da USIA (o que de fato acabou acontecendo durante o governo Kennedy). ${ }^{301}$

Thomas Sorensen indicava que a USIA deveria ser uma agência não só reativa às políticas estabelecidas pelo Departamento de Estado, mas também deveria centralizar todas as atividades de informação, cultura e educação, fornecendo diretamente ao Presidente, ao Estado e todas as outras agências subordinadas à Casa Branca com informações sobre o estado da opinião pública estrangeira, participando, dessa forma, também da elaboração da política externa e das decisões presidenciais. ${ }^{302}$

Lloyd Free, que consultou principais referências da área, concordou com a maioria das contribuições e compilou todas as sugestões em um relatório entregue à Kennedy em janeiro de 1961. Murrow, que contribuiu com opiniões com a força tarefa de Free-Sorensen-Wilson, sempre se referia ao relatório como referência contínua para ele e toda administração. ${ }^{303}$

Apesar do não reconhecimento público de Sorensen, podem ser identificadas algumas sugestões do relatório no dia a dia da gestão Kennedy. Murrow começou, de fato, a participar, mesmo que sem nomeação oficial, dos debates da Casa Branca sobre a elaboração da política externa, como do Operations Coordinating Board (OCB) (Bogart, 1995, p.35), que levava suas recomendações ao National Security Council (NSC), ${ }^{304}$ contribuindo na discussão, principalmente, com as pesquisas de opinião pública feitas pela USIA ao redor

301 Documento 29: "1960: Sorensen Report Recommendations".

302 Idem.

303 Documento 29: "1961: A study of USIA for President-elected Kennedy: Murrow a member of the task force". Apesar disso, Sorensen não identificava suas sugestões nas políticas da gestão Murrow.

304 Documento 29. 
do mundo (com olhar focado para grupos de interesse, cruzando opiniões políticas e preferências de entretenimento). ${ }^{305}$

Mesmo com o avanço em relação a governos anteriores, com um papel consultivo mais bem definido e participante, a USIA ainda continuava remediando as crises que aconteciam, sem participar das discussões diretas sobre essas. Mesmo com o maior destaque da USIA sob Murrow, internamente a agência era frequentemente vista como subordinada ao Departamento de Estado ${ }^{306}$ e nos momentos de maior crise da política externa de Kennedy, a sua participação se limitou a remediar os prejuízos à imagem americana causados pelos conflitos.

Murrow não foi consultado, por exemplo, sobre os planos de invasão da Baía dos Porcos, mesmo sendo a adesão dos povos locais uma variável fundamental para o sucesso da operação. Na crise dos mísseis de $1962^{307}$, por exemplo, Murrow não participou das discussões sobre os rumos a seguir. Por não ser consultado nessas ocasiões, e só posteriormente, Murrow cunhou a expressão, que "ele queria estar na decolagem, não somente no pouso forçado" (Bogart, 1995, p.xxix).

Muito se devia, principalmente, à descrença de alguns dos principais integrantes do governo, como o vice-Presidente Lyndon Johnson, do secretário de Estado Dean Rusk, e depois do diretor do Peace Corps, Sargent Shriver e Adlai Stevenson, com relação à USIA, e por acharem que as decisões mais importantes deveriam ser feitas secretamente, sem opiniões externas que tivessem base na opinião pública. ${ }^{308}$

Porém, apesar da falta de reconhecimento de parte do governo, a USIA na gestão de Murrow indiscutivelmente continuou se

305 Pells (1997, p.87) também destacava o interesse de Kennedy pela opinião pública estrangeira para definir as ações americanas.

306 Segundo Bogart (1995, p.xxix) até pela posição respeitosa de Murrow com relação ao Departamento, o próprio Secretário de Estado fazia essa confusão.

307 Sobre a crise dos mísseis, a invasão da Baía dos Porcos e a crise na Alemanha Oriental, (Sellers; May; McMillen, 1990, p.399-401).

308 Mais sobre essa divisão dentro do governo, com relação à USIA, em Pells (1997, p.89, 90). 
expandindo e se qualificando na gestão de Murrow. Nesse período, teve uma proposta mais bem definida em relação a regiões e grupos prioritários, focando suas atividades de acordo com pesquisas de mercado, constantes clippings de imprensa e sofisticando o planejamento no formato de "country plans". Desse modo, fortaleceu os USIS como partes ativas na formação das estratégias locais da USIA, tanto em relação a conteúdos direcionados, quanto à definição dos tempos ideais para divulgação de informações localmente $e^{309}$.

De 1961 a 1963, as mudanças da USIA tinham o objetivo de segmentar e qualificar as ações. O objetivo seguido era não mais atingir todos os segmentos das populações, mas atingir os necessários. Era o objetivo atingir determinados grupos-chave e não mais o difuso objetivo de seu lema originário: "To tell America's story abroad" ${ }^{310}$

Seguindo essas orientações, a USIA de Kennedy/Murrow se adaptou. Um coordenador de mídia foi designado para coordenar as estratégias dos diversos meios de comunicação (rádio, TV, filmes, mídia impressa) quanto às ações, conteúdos e divulgação, de acordo com diretrizes locais, regionais e globais. Também foi criado o cargo de "long range planning officer" para definir as diretrizes das atividades não imediatas e traçar os caminhos e objetivos da mídia a serem alcançados entre 5 e 10 anos.

Como havia recomendado o relatório de Sorensen, a juventude e o público estudantil foram focos estratégicos da USIA no período. E para coordenar políticas para esses grupos, foi nomeado um "youth and students affairs officer", responsável por planejar e promover atividades e objetivos para esses setores. Por último, durante o período foi indicado outro officer responsável somente para garantir a efetiva aplicação dos resultados das pesquisas locais nas políticas e programas da agência.

Nos USIS e postos locais, algumas modificações operacionais visavam à diminuição da burocracia e aumento da qualidade do

309 Documento 29: "1963: I/R's Account of Changes in USIA/USIS During Murrow Administration”.

310 Documento 29. 
serviço no "campo". A quantidade de relatórios e ofícios sem conteúdo político, de caráter burocrático, entre os USIS e a sede da USIA foi diminuída em 20\%. Ao mesmo tempo, estimulou-se o aumento do tempo de serviço dos funcionários americanos dos USIS nos países (em média, de 2 para 3 anos), mantendo funcionários especialistas com contatos já estabelecidos e consolidados nesses locais. Segundo relatório interno da agência, a ideia era que "... nos postos do exterior, o trabalho com os papéis foi subordinado ao trabalho com as pernas". ${ }^{311}$

A coordenação entre os postos nos 106 países onde a agência tinha representações em 1963, era a de passar, por variados meios de comunicação e de diferentes maneiras para os distintos grupos, a mesma mensagem de maneira articulada, para atingir os resultados ambicionados mais efetivamente.

Para isso, cada PAO tinha que passar a mesma mensagem para sua equipe local de informação e para o posto diplomático onde trabalhava, além de servir como referência para ações psicológicas na representação americana local. ${ }^{312}$

Para as atribuições internas do governo, em janeiro de 1963 Kennedy definia bem o papel importante que a USIA desempenhava e definia a missão consultiva da agência como representante da opinião pública mundial na Casa Branca e demais Departamentos, com responsabilidade para: "assessorar o Presidente, seus representantes no exterior, e os vários Departamentos e agências sobre as implicações da opinião estrangeira para as políticas, programas e discursos oficiais americanos presentes, e os pensados para o futuro". 313

Outro resultado dos relatórios iniciais para Kennedy (além dos acontecimentos políticos, como a independência dos países africanos e a revolução cubana) foi a ênfase especial na África e na América

311 Idem: O relatório interno sobre a gestão de Murrow é referência essencial para entender o período de 1961-63: "1963: I/R's Account of Changes in USIA/ USIS During Murrow Administration”.

312 Documento 29: "1963: I/R's Account of Changes in USIA/USIS During Murrow Administration".

313 Idem. 
Latina como regiões prioritárias. De 1961 a 1963 a USIA abriu 12 novas missões, 8 postos avançados na África e 11 novos postos no subcontinente americano. Para se ter uma ideia do nível dessas prioridades, durante o mesmo período 3 novos postos foram abertos, enquanto na Europa Ocidental foram fechados 4 postos avançados e somente um novo foi aberto na região.

A prioridade também foi vista na escolha da visita do Presidente Kennedy na América Latina, em 1961, e na cobertura especial dada pelos meios de comunicação administrados pela USIA no lançamento da Aliança para o Progresso. Durante a visita, houve ainda a publicação de panfletos e revistas especiais sobre a visita de Kennedy em cada país, além de filmes, programas de rádio e notícias exclusivas. $^{314}$

O programa propunha um financiamento de US\$ 20 bilhões para os países latino-americanos por meio da recém criada U.S. Agency for International Development (USAID). O detalhe interessante é que a partir da decisão de Eisenhower, em 1953, de unificar na USIA todas as atividades de relações públicas exteriores do governo, inclusive as das agências de cooperação internacional como a USAID, todas as ações relacionadas com a divulgação e articulação no exterior das atividades da Aliança para o Progresso e outros programas de cooperação estavam automaticamente vinculadas à USIA (Sorensen, 1968, p.133).

A gestão Kennedy/Murrow também inovou na qualificação da infraestrutura da mídia. Para isso criou um centro de imprensa para os correspondentes estrangeiros que cobriam as notícias sobre os EUA (e sobre a ONU) em Nova York. O centro também facilitava o acesso a informações atualizadas e qualificadas de autoridades americanas e estrangeiras. ${ }^{315}$

314 Documento 29: “1963: I/R's Account of Changes in USIA/USIS During Murrow Administration”.

315 Documento 29: "1963: I/R's Account of Changes in USIA/USIS During Murrow Administration”. 


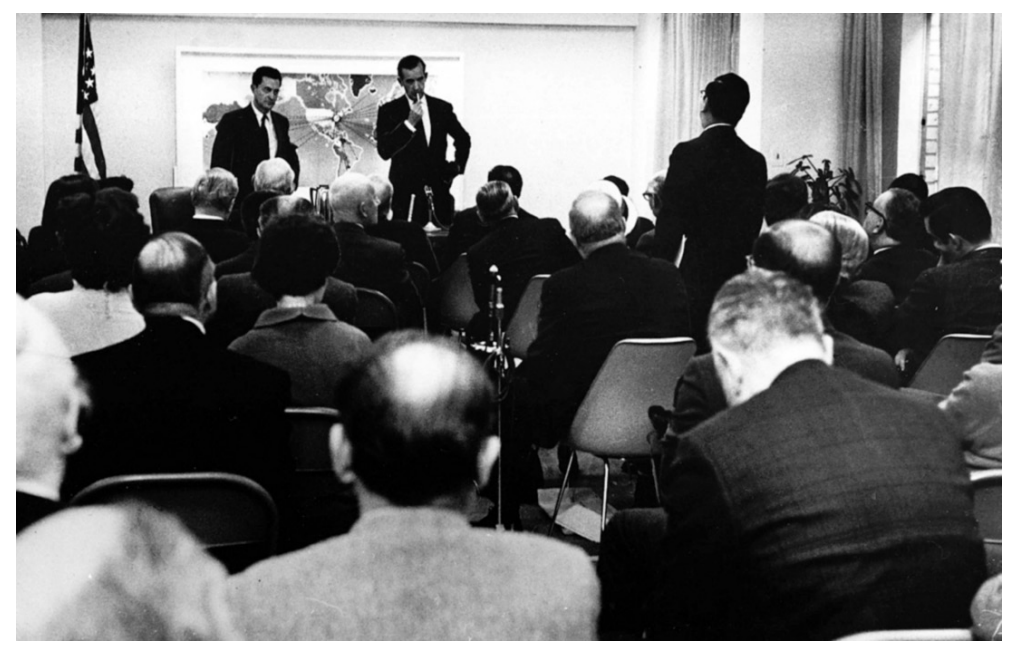

Figura 27 - Murrow em coletiva para correspondentes estrangeiros no Foreign Correspondence Center da USIA em Nova York, em 1962.

Para Murrow, o contato direto com jornalistas estrangeiros era fundamental para o convencimento sobre as razões americanas em momentos de conflito. Segundo Murrow “.... melhor forma de propaganda é ainda a cara-a-cara, persuadindo o importante editor de jornal e a liderança no governo sobre a correção de nossas posições e de que nossos objetivos estão em harmonia com o deles". ${ }^{316}$

Em fevereiro de 1963, a USIA dobrou a capacidade de transmissão em ondas curtas do Voice of America, com um novo centro de transmissão (em Greenville, North Carolina), de 5 milhões de watts (equivalente ao poder de transmissão de 96 estações de rádios comerciais dos EUA na época), para melhorar principalmente o sinal do VOA na América Latina, Europa e África. ${ }^{317}$ Além disso, quatro transmissores que poderiam ser transportados por avião foram construídos e colocados em lugares estratégicos. O que atingiria a

316 Documento 29: "1961: Murrow-face-to-face persuasion is the best".

317 Documento 29: "1963: I/R's Account of Changes in USIA/USIS During Murrow Administration”. 
América Latina foi colocado em Marathon Key (Flórida), com forte sinal em Cuba.

Os programas transmitidos em ondas curtas do VOA também melhoraram a qualidade de sua programação, aumentando de uma para nove horas diárias os programas em mandarim (para China) e espanhol (para América Latina), e inaugurando sua programação exclusivamente em português para o Brasil. ${ }^{318}$ Além dos canais do VOA, cerca de 5.500 estações comerciais em todos os continentes transmitiam programas gravados do VOA em 1963.

A USIA também aumentou sua produção de filmes de 1961 a 1963, e tinham no Presidente e sua família como suas principais estrelas no exterior. Dos 36 documentários produzidos durante o período, 31 eram sobre visitas de autoridades americanas no exterior ou de Presidentes estrangeiros em Washington DC e temas correlatos. A USIA também comprou os direitos de exibição de 66 filmes produzidos independentemente, a custo menor, e os distribuía por meio de 1.173 rolos exibidos em organizações, associações, hospitais, fábricas, associações comerciais, fundações, museus e centros culturais em todo mundo.

Uma reportagem de 1963, ${ }^{319}$ que descrevia os filmes de maior sucesso da USIA sobre a família Kennedy, destacava que por princípio eles eram exibidos somente no exterior, mas mostravam as atividades de JFK e sua mulher Jacqueline também em atividades nos EUA. O filme American journey, por exemplo, apresentava o cotidiano da primeira dama, visitando crianças doentes em hospitais, ou em uma solenidade na Filadélfia, e em seu final a intimidade da família na Casa Branca.

Os filmes sobre os Kennedy fizeram tanto sucesso no exterior que viraram até tema de piada em um disco de sucesso de Louis Armstrong, Dave Brubeck, Carmen Mcrae, e outros músicos que

318 Documento 29: “1963: I/R's Account of Changes in USIA/USIS During Murrow Administration".

319 Documento 51: "USIA Films Admirable Lot", de Richard L. Coe, Washington Post. 
contavam a história dos artistas de jazz que, financiados pelo Departamento de Estado representavam os EUA no exterior. ${ }^{320}$

No disco The real ambassadors (1961), Louis Armstrong brinca que, mais do que o maior atleta (negro) de beisebol norte-americano, Jackie Robinson, quem era o símbolo dos EUA no exterior do governo era a primeira-dama. Na música que abre o disco, chamada "Cultural Exchange", a letra descreve, com humor e ironia, as escolhas da USIA no caso de conflitos mundiais: "(Louis Armstrong) Yeah, e se o mundo fica doido, nós pedimos ao John que mande a Jackie, (coro) Jackie Robinson? (Louis Armstrong) Não cara, a primeira-dama! É isso o que chamamos de intercâmbio cultural, é isso o que chamamos de intercâmbio cultural".

Outra reportagem, de 2 de novembro de 1962, descrevia, sem muita simpatia, os filmes da USIA sobre os sucessos dos movimentos civis nos EUA, como um avanço da democracia americana a ser exaltado no exterior. A notícia publicada pelo jornal Christian Science Monitor, intitulada "USIA Film Depicts Positive Negro Gain", descrevia a posição do responsável pela série de filmes Negro - A century of progress: "Ao invés da situação do Preto ${ }^{321}$ ser uma fragilidade no exterior - como os comunistas tentam constantemente pintar - nós estamos tentando mostrar a visão de que ela reflete um avanço afirmativo para todas as pessoas dos EUA". ${ }^{322}$

O sucesso dos filmes da USIA se devia, em grande parte, à ideia de Murrow que buscava renovação da linguagem dos filmes produzidos pelo Departamento de Filmes da USIA, antes dominados por documentários tradicionais com perfil educacional ou científico. Murrow foi buscar em um jovem herdeiro das grandes indústrias de Hollywood o seu novo diretor para o Departamento.

320 Mais referências sobre o disco e as turnês de jazz no exterior em Von Eschen, 2004.

321 "Negro", em inglês.

322 Documento 51: "1962: USIA Film Depicts Positive Negro Gain”, Christian Science Monitor, 29/11/62. 
Após tentar convencer Sam Goldwin Jr. sem sucesso, Murrow convidou George Stevens Jr., ${ }^{323}$ que com menos de 30 anos de idade mudou o perfil dos filmes da USIA. Pelos seus contatos, Stevens Jr. mobilizou os melhores produtores de Hollywood para confeccionar filmes atraentes e agradáveis de serem vistos para atingir todos os tipos de público. Além disso, a USIA contratava produções independentes locais para exibição de temas regionais específicos.

Por fim, Murrow também tentou dialogar com Hollywood para que fossem produzidos tramas mais favoráveis aos EUA, em nome da luta contra o comunismo. Para ele, após uma viagem à Europa e América Latina em 1961, era clara a promoção de uma imagem americana "indesejável e exagerada" ${ }^{24}$ no exterior. Em reunião com a Academy of Motion Picture Arts and Sciences, Murrow disse que os estrangeiros tinham uma imagem completamente distorcida dos EUA.

Na ocasião, o diretor da USIA chegou a declarar que os EUA não poderiam ser vistos como terra de gangues, índios e mulheres com seios fartos:

Muita gente no exterior pensa que para lá do Mississipi ficam lugares desertos, ameaçados por índios hostis; que todos os outros americanos vivem em apartamentos de cobertura; muita gente do mundo também acredita que Chicago é assolado por uma guerra de gangues; e que uma mulher que não tenha 100 centímetros de busto não pode ser americana. ${ }^{325}$

323 Documento 51: "Murrow attempts to revitalize IMV output: only partially successful”. Seu pai, George Stevens, foi diretor de sucesso que já havia ganhado, entre outros prêmios, o oscar pelo filme "Giant", em 1956. George Stevens Jr também foi fundador da American Film Institute, e posteriormente foi diretor premiado de cinema e televisão (ganhador do prêmio Emmy).

324 Documento 51: "1961: Murrow tried "to influence" Hollywood films to improve U.S. image abroad".

325 Documento 51: "1961: Murrow urges Hollywood to portray U.S. more accurately in its films.". 
Sua tentativa não foi bem aceita pelo mundo de Hollywood. Segundo a revista Variety, sua postura como diretor da USIA contrariava toda sua honrada história como jornalista: "Como um burocrata, ele assumiu a perspectiva da propaganda, que é oposta à da posição adotada em sua longa carreira como apresentador de noticiário". 326

A ação da USIA também incentivou e apoiou a produção de filmes sobre ciência, por meio dos American Science Films Forums e a divulgação de filmes americanos no exterior, patrocinando festivais de cinema, como o de Cannes e Veneza (em 1962) e em Moscou e Berlim. Nessas ocasiões, o próprio George Stevens Jr. foi o chefe das delegações americanas nos eventos. Como resultado dessas atividades conjuntas a USIA criou o Hollywood Guilds Festival Committee, que selecionaria filmes comerciais americanos para participarem de festivais no exterior. ${ }^{327}$

Outra prioridade da gestão Kennedy era o fortalecimento e maior agilidade das pesquisas de opinião pública de determinados grupos e países. Durante a crise dos mísseis de 1962, por exemplo, a USIA preparava dois informes sobre a reação da opinião pública global por dia. As pesquisas também faziam um controle qualitativo, testando com antecipação alguns dos programas de rádio, TV e cinema produzidos pela USIA. De acordo com a reação do público selecionado, os produtos eram exibidos ou não. ${ }^{328}$

Muitos dos estudos específicos eram encomendados a acadêmicos e especialistas americanos, fundações e universidades. Uma unidade de pesquisa de projetos especiais, estabelecida em janeiro de 1962, também incentivou e financiou certos grupos e temas de pesquisa de interesse governamental.

326 Documento 51: "1961: Murrow tried "to influence" Hollywood films to improve U.S. image abroad". Sobre ambivalência entre os papéis de Murrow como jornalista consagrado e diretor da USIA também descrito em Pells (1997, p.90).

327 Documento 29: "1963: I/R's Account of Changes in USIA/USIS During Murrow Administration”.

328 Documento 29: "1963: I/R's Account of Changes in USIA/USIS During Murrow Administration”. 
READING, PA., FRIDAY MORNING, FEBRUARY 17, 1961 'Now a Word From My Sponsor' Sylvi

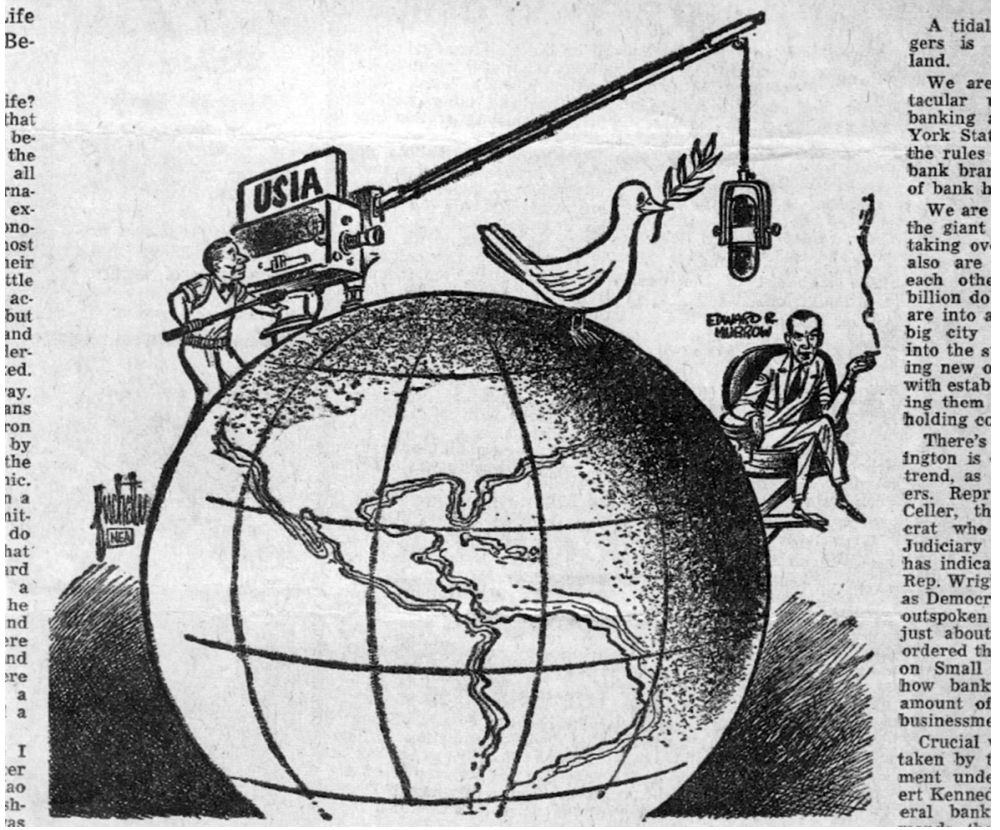

Figura 28 - Caricatura sobre novo programa de Murrow, patrocinado pela Paz Mundial.

Entre os temas de especial interesse da USIA estavam os estudos sobre os desenvolvimentos regionais, o conflito ideológico e a semântica política, ou seja, estudos de significados de termos políticos usados diferentemente de acordo com país, como, por exemplo, o significado de "socialismo", "comunismo", "capitalismo", ou "liberdade" para diferentes setores sociais dos países. Relatórios diários sobre as atividades de propaganda comunista também eram produzidos em todos os postos locais da USIA, com foco principal na URSS e em Cuba. ${ }^{329}$

329 Documento 29: "1963: I/R's Account of Changes in USIA/USIS During Murrow Administration”. 
A cooperação privada também se expandiu de 1961 a 1963, aumentando o volume das atividades da USIA, que normalmente seriam restritas à capacidade de seu orçamento. Um dos exemplos é o transporte dos livros doados ao exterior, que durante o período levou mais de 800 mil livros e outros materiais (que ficavam estocados nos armazéns da USIA no Brooklyn e em DC) ao exterior sem despesas para a agência. O U.S. Post Office também doou à USIA todos os livros que estavam na correspondência perdida dos correios (de 100 a 150 mil anualmente). ${ }^{330}$

Durante os três anos de Kennedy, a USIA também fornecia informação estratégica e política a cerca de 8 mil empresários americanos que trabalhavam no exterior, em mais de 441 empresas americanas com representações no exterior. Em parceria com a indústria americana, os empresários eram atualizados sobre temas como os tratados de não proliferação nuclear e detalhes específicos sobre a política externa dos EUA. ${ }^{331}$

Isso era resultado da aproximação ativa dos PAO officers no exterior, que buscavam os empresários americanos em outros países para dialogar sobre temas da política externa que afetavam os negócios e a partir daí também prospectavam possíveis ações conjuntas com empresas americanas. A USIA, secretamente, também mapeava correspondentes americanos no exterior e suas orientações políticas, controlando o fluxo de informações americanas que vinham de fora e as possibilidades de colaboração com jornalistas americanos em outros países. ${ }^{332}$

A ênfase anterior à doação de livros usados deu lugar à de materiais novos. Muitas das revistas privadas americanas que tinham mercado no exterior também recebiam encartes e materiais da USIA que eram lidos como suplementos, como resultado de parceria da agência com editoras privadas. Em 1963, mais de um milhão de pessoas recebiam as 67 diferentes publicações da agência. Eram

330 Idem.

331 Idem.

332 Documento 61: "IRS - U.S. News Media Representatives serving abroad". 
também distribuídos para as bibliotecas dos USIS alguns materiais de maior qualidade gráfica, produzidos pela USIA, e que versavam sobre a indústria, a ciência e tecnologia e o empreendedorismo americano. $^{333}$

O ano de 1963, por exemplo, foi o ano mais produtivo da história da agência até então, com 1202 publicações diferentes, com mais de 10 milhões de cópias distribuídas em 36 línguas. Só na América Latina a tradução de obras americanas cresceu de 64 edições e 540 mil cópias em 1961, para 332 edições e 3 milhões e 500 mil cópias em 1963 (em português e espanhol). ${ }^{334}$

A partir de 1962, doações privadas de empresas e de pessoas também financiaram 12 mil kits de esportes (para prática do basquete, vôlei, baseball, futebol e boxe), que eram distribuídos aos USIS em mais de 86 países por meio do comitê de esportes do programa People-to-People.

As empresas americanas até financiavam os passeios de "re-familiarização" dos funcionários da USIA e suas famílias nos EUA, entre os trabalhos em um posto e outro. A Wally Byam Foundation oferecia três automóveis do tipo "trailer", bem como os custos de manutenção, gasolina, óleo e seguro para o uso recreativo dos funcionários da USIA. Um relatório interno das atividades da agência desde 1961, citava que durante o ano de 1963: "Vinte funcionários dos USIS e suas famílias beneficiaram-se desta oportunidade neste ano, de readaptarem-se ao estilo de vida tradicional do país do qual eles serão porta-vozes em seu próximo trabalho no exterior". ${ }_{335}$

Outra preocupação inicial da gestão Kennedy, a qualificação e treinamento dos funcionários da USIA também foi objeto de uma política específica durante aqueles anos, por meio de cursos de 8 semanas e línguas a recém selecionados e funcionários administrativos do serviço exterior. Além disso, foram oferecidos cursos para 25

333 Documento 29: “1963: I/R's Account of Changes in USIA/USIS During Murrow Administration”.

334 Idem.

335 Idem. 
funcionários em situação de mid-career por ano, alguns já com postos de USIS officers.

A USIA também promovia seminários para seus funcionários sobre determinados temas prioritários para a agência, como relações estudantis, sindicalismo internacional, triunfos americanos no espaço e o desenvolvimento em áreas subdesenvolvidas. Só em 1963, mais de 1.200 funcionários participaram dessas capacitações. ${ }^{336}$

$\mathrm{Na}$ área de produção de filmes, a USIA desenvolveu, a partir de 1962, uma bolsa de estágio para 5 jovens cineastas por ano, que treinavam na agência técnicas de filmagem e eram capacitados sobre conteúdos e linguagens. Depois, esses jovens eram encaminhados para os centros de produção locais, para multiplicar os conhecimentos e capacitar os técnicos dos países. ${ }^{337}$

$\mathrm{Na}$ área de publicações, foi dada uma grande ênfase ao desenvolvimento de materiais mais rápidos de serem lidos e assimilados. Um dos grandes meios para disseminar esse tipo de linguagem eram os quadrinhos, que contavam a história americana criticando os líderes comunistas, como a série de revistinhas que contavam a Aliança para o Progresso e com conteúdos anticastristas para o público da América Central e do Sul. Muitas tiras também eram distribuídas para as publicações em jornais, como a True Tales, feitas diariamente também em espanhol. ${ }^{338}$

Para as notícias, um novo aparato de imprensa foi criado. Um laboratório para impressão e distribuição de quase 20 milhões de fotos e negativos, ao ano, foi modernizado. Impressoras eletrônicas (chamadas de Log-E-Tronics Unit) foram compradas. ${ }^{339}$ Também foram remodelados os sistemas de cobertura de imprensa, de edição (copy desk) e diagramação. A tecnologia de envio de notícias "sem-fio" (com radio-phone e telégrafos) também foi sofisticada,

336 Documento 29: "1963: I/R's Account of Changes in USIA/USIS During Murrow Administration".

337 Idem.

338 Idem.

339 Documento 29: “1963: I/R's Account of Changes in USIA/USIS During Murrow Administration”. 


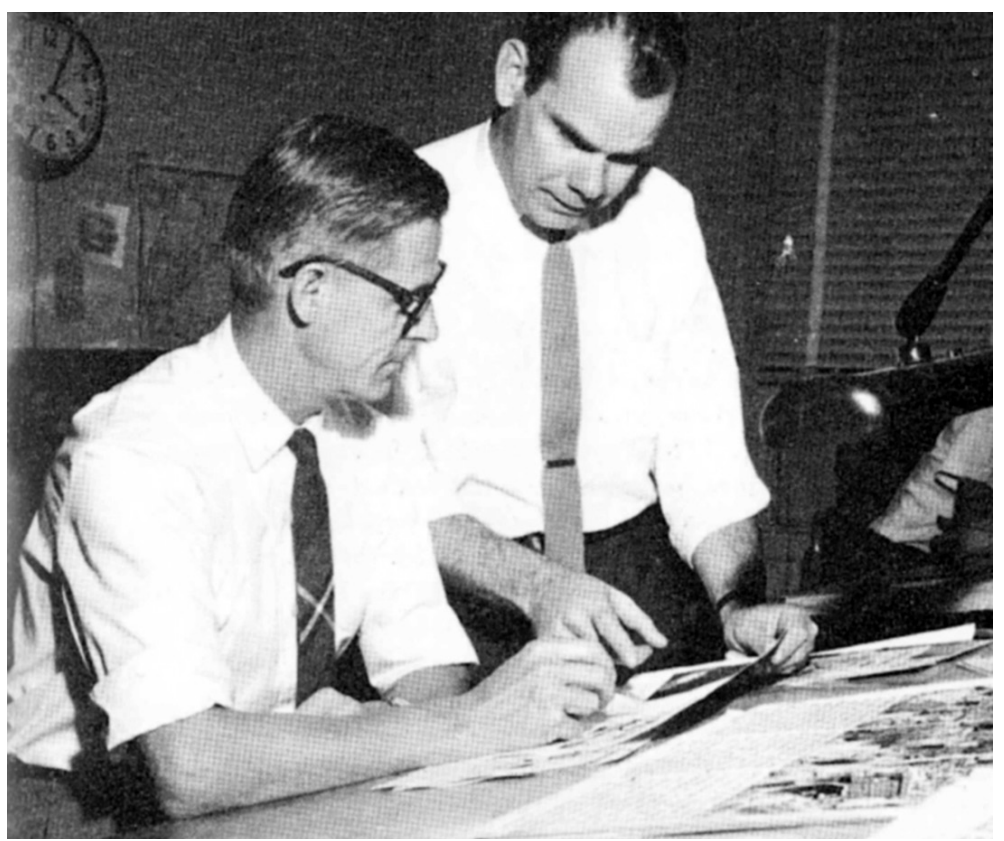

Figura 29 - Cartunistas da confeccionando tiras para centenas de jornais em diversas línguas.

principalmente para a recepção no continente africano. De 111 novos postos de recepção, entre 1961 e 1963, 33 deles foram na África.

No continente americano foi estabelecido um novo centro regional de imprensa em 1962, dedicado principalmente a produzir notícias para os públicos estudantis, sindicatos e ex-beneficiados pelo programa Aliança para o Progresso. ${ }^{340}$

A USIA também continuou a promover o intercâmbio de artistas e jornalistas com fins políticos, além de criar, em 1961, o cargo de Assistant Secretary of State for Educational and Cultural Affairs, que continuaria a tradição reivindicada por Fulbright no Departamento de Estado, com o perfil de longo prazo e sem interesses políticos aparentes (Pells, 1997, p.91). 
Para o contato direto com o público de interesse, a USIA de Murrow também intensificou as feiras e exposições, inicialmente no bloco soviético (o que era previsto nos acordo de intercâmbio cultural EUA-URSS) e posteriormente em países do leste europeu. As exposições mostravam equipamentos, com o mais alto grau de tecnologia e inovação em algumas áreas, com temas como "Plastics USA", "Transportation USA", "Medicine USA", "Technical Books USA", "U.S. Astronaut Orbits the Earth", "Friendship Seven Mercury Capsule" (que levava uma cápsula da NASA para 23 países), "U.S. Progress in Space Sciences" ou "Graphic Arts USA". ${ }^{341}$

A produção específica para a televisão era também uma preocupação da gestão Murrow à frente da USIA, e para isso foram comprados equipamentos próprios e criados 22 novos postos na agência: 10 para a produção, 6 na equipe técnica, 4 na programação, e 2 na administração. Em 1962, a USIA produziu 101 horas de programas próprios; em 1963, foram 113 horas de filmes específicos para TV.

Só no ano de 1961, os programas de TV produzidos e comprados pela USIA foram exibidos em mais de 40 novas estações em todo o mundo. Programas como World Americana, que exibia os programas de lazer do americano médio, ou a rotina das donas de casa e juventudes americanas, ou o Personal Report, que mostrava as primeiras impressões de um estudante nigeriano nos EUA, mostravam o lado americano que vivia em paz e harmonia.

Para exibição em 19 países da América Latina, eram produzidas séries de 13 horas, como o The Experts Answer, que levavam jornalistas latino-americanos a entrevistar especialistas americanos em assuntos como governo, trabalho, indústria, ciência e artes plásticas. Outro tipo de programa, semanal e com 15 minutos de duração, como o "Panorama Panamericano", também era exibido nos canais comerciais de televisão no subcontinente. Filmes especiais para a TV também foram produzidos para a região, como os Report from Colombia,

341 Documento 29: "1963: I/R's Account of Changes in USIA/USIS During Murrow Administration”. 
ou o Report from Venezuela, mostravam o progresso na região a partir do programa Aliança para o progresso. Outros como o Focus: Cuba, Cuba - A world verdict, The lost apple, Castro and Cuba, entre outros, mostravam o lado sombrio e antidemocrático da revolução cubana. ${ }^{342}$

A TV USIA também produziu uma série de sucesso chamada Let's Learn English, transmitida para 37 países, atingindo milhões de pessoas. Por causa do sucesso da série, um segundo programa foi produzido e exibido no mesmo formato, sendo chamado de Let's Speak English. Outros programas com temas específicos, como o Science Reports, que exibia os progressos da ciência americana, fizeram sucesso em mais de 52 países do mundo.

A gestão de Kennedy também teve a preocupação de mudar o perfil dos funcionários da USIA, colocando mulheres em posição de chefia na agência ( 4 foram citadas em cargos de chefia, entre os postos USIS e administração em Washington DC). Negros também foram admitidos como parte desta política: "O número de funcionários Pretos no serviço exterior quase dobrou em relação aos números de 1960, de 24 pessoas. Três country public affairs são Pretos. Quase $10 \%$ de todos os funcionários do serviço exterior com postos iguais ou maiores que GS-12 são Pretos". ${ }^{343}$

Apesar das críticas de campanha de Kennedy, a principal iniciativa de Eisenhower pela amizade entre os povos, o bem-sucedido People-to-People continuou sendo acompanhado pela USIA no novo governo, apesar de financiado quase completamente por empresas.

As iniciativas do Sister Cities continuaram a crescer, estimulando a troca de experiências entre comunidades principalmente nas áreas de educação, com programas de intercâmbio de alunos e professores. A inovação da USIA de Murrow para fortalecer as Sister Cities americanas na América Latina foi articular os trabalhos dessas com os centros binacionais na região, usando os equipamentos disponíveis, como bibliotecas, salas e auditórios como "embaixadas informais"

342 Documento 29.: "1963: I/R's Account of Changes in USIA/USIS During Murrow Administration"

343 Idem: relatório interno das ações da USIA de 1961 a 1963. 
das cidades americanas no exterior, exibindo filmes e promovendo programas cívicos e palestras. ${ }^{344}$

Nos anos Kennedy/Murrow, a USIA conseguiu multiplicar seu alcance e eficiência, menos pelo aumento de seu orçamento, muito mais pelo trabalho em parceria com a iniciativa privada e pelo foco em grupos específicos, baseados em pesquisas de mercado. A divisão do trabalho interno da agência também foi bem feita. Enquanto Murrow era a cara pública da USIA, dialogando com diversos setores internamente e externamente, Donald Wilson era seu gestor interno.

A agência em seu auge, com a Guerra Fria a todo vapor, parecia ser cada vez mais parte integrante de uma estratégia maior e fundamental para o futuro mundial, influenciando direta e indiretamente o modo de pensar, divertir e agir politicamente em todos os países do mundo. Porém dois acontecimentos inesperados e quase concomitantes mudaram o destino da USIA dentro do governo americano e no modo americano de agir, se comunicar, dialogar e influenciar outros países.

O primeiro foi o assassinato do Presidente Kennedy, em 22 de novembro de 1963 e a posse do vice-Presidente Lyndon Johnson, no mesmo dia. As diferenças entre as concepções dos dois Presidentes em relação à importância do aspecto psicológico entre as "armas" americanas e na consideração da opinião pública de outros países como fator relevante para a definição da política externa foram decisivas para o futuro da agência a partir daquele dia.

O segundo acontecimento foi o adoecimento de Murrow, símbolo da USIA em seu auge. Em setembro de 1963, o diretor da agência cancelou um discurso por suspeita de laringite, quando foi descoberto um câncer de pulmão. A operação que retirou parte de seu pulmão foi seguida de radioterapia. Murrow pediu afastamento ao Presidente Kennedy após a sua operação e após o assassinato de JFK, Murrow foi se retirando de seus afazeres profissionais. ${ }^{345}$

344 Documento 53: "Sister City Program Expanding. May, 1963".

345 Documento 49: "1963: Murrow came down with cancer in September: resigned in December but note accepted until January 20/64". 
Com isso, a partir do final de 1963, Wilson acabou por assumir também a parte mais pública da agência, além de manter a gestão interna. E continuou administrando esse momento crítico da história dos EUA e da USIA (Elder, 1968, p.42), até o pedido definitivo de demissão de Murrow, aceito com relutância pelo Presidente Johnson, em 20 de janeiro de 1964.

$\mathrm{Na}$ carta em que aceita sua renúncia, o Presidente americano pedia ajuda a Murrow como consultor no futuro:

Caro Ed, [...] eu respeito sua posição de que uma longa recuperação decorrente de um problema de saúde impeça sua permanência no cargo; o mesmo alto espírito de responsabilidade que trouxe você à Washington agora obriga você a partir. Mesmo assim, eu admito que eu esperava que você pudesse ficar. Após a sua recuperação, eu te ligarei para ter seus conselhos e ajudas. [...]Você parte com a gratidão de um Presidente e de uma nação. Eu encerro, Ed, parafraseando as palavras que te deixaram para sempre famoso no rádio e na televisão: "Goodbye, and Good luck!" ${ }^{346}$

Wilson ficou como responsável pela transição, ajudando a nova direção da USIA até agosto de 1965, quando renunciou para assumir a direção geral da revista Time-Life International. ${ }^{347}$

Murrow, por sua vez, não resistiu ao câncer por muito tempo, falecendo em abril de 1965. Toda documentação referente à sua gestão, até então nos arquivos da USIA, foi doada ao "The Edward R. Murrow Center of Public Diplomacy”, criado em julho do mesmo ano na Fletcher School of Law and Diplomacy da Tufts University. O centro havia sido idealizado pelo próprio Murrow e reuniria acadêmicos, jornalistas, estudantes e funcionários do governo para pensar o que foi chamado desde então de Public Diplomacy. ${ }^{348}$

346 Documento 58: "The White House, Text of letters exchanged by the President and the Honorable Edward R. Murrow, January 20, 1964".

347 Documento 59: "Wilson Steps Out Aug. 1 As USIA Deputy Chief".

348 Documento 60: "The Edward R. Murrow center of Public Diplomacy/The Agency Library, archives collection". 
A agência chegou a seu auge de importância interna e atividades externas com Kennedy, Murrow (e Wilson), segundo o que foi descrito por um de seus funcionários, Wilson P. Dizard Jr. (2004, p.4):

A USIA tinha uma tarefa especial para projetar as ideias americanas aos quatro cantos do mundo. No auge das suas operações da Guerra Fria, ela teve a presença mais extensa no exterior do que qualquer outra agência de Washington. Seus postos culturais e de informação - os U.S. Information Services (USIS) - funcionavam em quase trezentas cidades. Ao todo, era o maior esforço cultural e informacional já feito por uma sociedade para influenciar as atitudes e ações de homens e mulheres além de suas fronteiras.

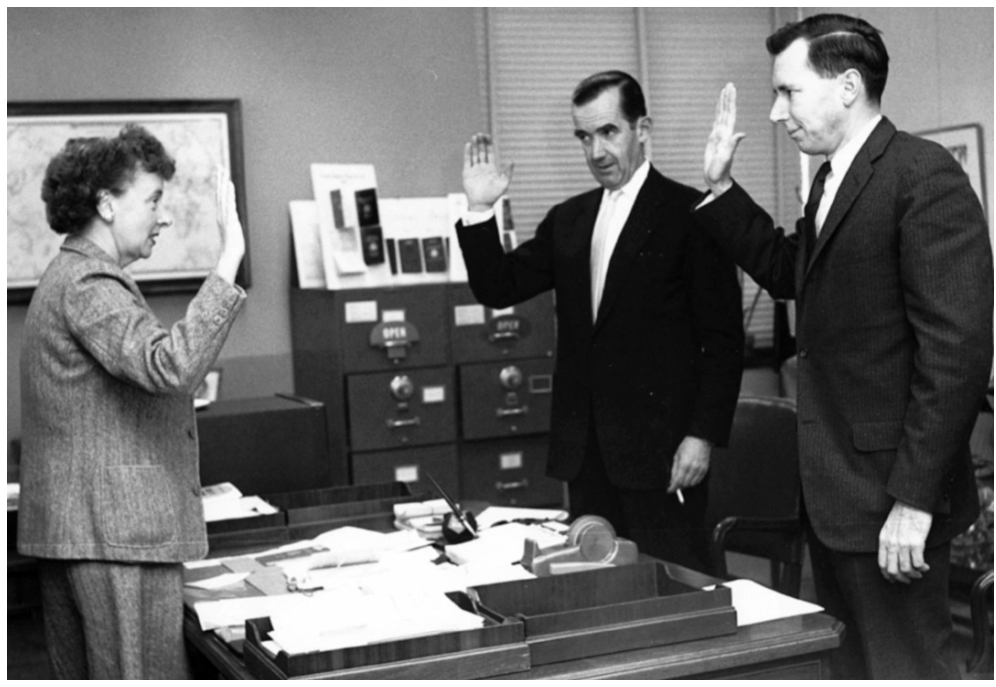

Figura 30 - Murrow e Wilson, aqui em seus juramentos, representaram a época de ouro da USIA. Após a morte de Kennedy e suas saídas, mudanças profundas na agência começaram a ser sentidas.

O governo JFK, no entanto, deixava a seu sucessor sérios desafios conjunturais. Sem resolver o problema iniciado por Eisenhower no Vietnã (aumentando o contingente militar norte-americano naquele país) (Sellers; May; McMillen, 1990, p.402) e após diversas 
crises internacionais (como a da invasão mal sucedida na Baía dos Porcos e a crise dos mísseis), o Presidente Lyndon Johnson assumiu em um dos momentos mais críticos também da história interna americana, após o assassinato de Kennedy.

A USIA sofreu os ecos das mudanças advindos desse momento turbulento, refletidos também pelo perfil do novo Presidente em exercício. Uma nova conjuntura nacional, com consequências internacionais, inclusive no Brasil, surgia com a morte de Kennedy e a posse de Johnson, no final de 1963.

\subsection{Johnson e o começo da inflexão da USIA}

Em um momento delicado da vida americana, Lyndon Johnson assume com o dever de reverter o quadro de crise nacional e internacional que se apresentava. Além de todos os problemas já conhecidos e vastamente estudados (Revolução cubana, Vietnã, investigação do assassinato de Kennedy), Johnson também tinha o problema de substituir o diretor da agência mais reconhecido publicamente.

Para o seu lugar deveria chamar alguém que mantivesse a boa imagem norte-americana no exterior, que tivesse noção do grave momento em que a política externa norte-americana passava e por isso trabalhasse bem em conjunto com outros órgãos do governo. Além disso, era necessário que fosse uma pessoa com experiência na área, tanto de comunicação quanto de relações internacionais.

Em 23 de janeiro de 1964, três dias após a renúncia de Murrow, a imprensa americana já anunciava a indicação do novo Presidente para a direção USIA: Carl T. Rowan. Jornalista e ex-correspondente no sudeste asiático, Rowan assumiu o cargo de Assistant Secretary of State for Public Affairs e depois o de embaixador americano na Finlândia. ${ }^{349}$

349 Documento 60: "Murrow to Rowan, U.S. to the World (Springfield, Mass. Union, Jan 23, 1964)". 
Tido como um estudioso de política externa e habilidoso em sua relação com os jornalistas, Rowan era destacado pela imprensa americana da época principalmente pela sua cor de pele. Na ocasião, era o negro com maior posto dentro do governo ${ }^{350}$ e por isso, segundo as reportagens da época, levava em si a imagem que o governo americano queria mostrar ao mundo: de um país que inclui as minorias, de uma democracia que possibilita a ascensão social de qualquer cidadão, inclusive nos maiores postos do governo.

Isto, segundo as reportagens, era a vantagem mais óbvia que a nomeação de Rowan trazia para o posto na USIA: "talvez ele necessite de mais apoio do que o Sr. Murrow com relação à gestão das notícias, mas como um Preto ele está em uma posição também exemplar para mostrar o progresso que a América está fazendo com relações aos problemas raciais". 351

Desde o início de sua passagem pela USIA, Rowan se colocava como discípulo da bem avaliada gestão de Murrow. A grande diferença entre as duas administrações se dava na relação mais distante que Rowan tinha com o Presidente e na menor importância que Johnson dava à USIA, à opinião pública estrangeira e às políticas de informação. ${ }^{352}$

Também por isso e por ser ex-diplomata, Rowan se reportava diretamente ao Departamento de Estado e desde o início, agindo como se a USIA estivesse subordinada formalmente às diretrizes da política externa, quase como se fosse a assessoria de imprensa do Secretário de Estado. Para Rowan, que se reunia diariamente com o próprio Secretário, ou com Under Secretary of State for Public Affairs, ${ }^{353}$ a principal tarefa da USIA era explicar ao público internacional as

350 Documento 60: “Ed Murrow's Contribution (Roanoke, Virginia Times, Jan 26, 1964)".

351 Documento 60: "Murrow to Rowan, U.S. to the World (Springfield, Mass. Union, Jan 23, 1964)".

352 Documento 30: "1964-65: Rowan shared Kenedy-Murrow view of USIA as a useful tool of foreign policy - but not supported by White House".

353 Documento 31: "1965: Rowan describes machinery for giving USIA policy guidance/ S: USIA Approp. '66, p.237 (June 14)”. 
intenções e objetivos da política externa americana e fazer com que os povos estrangeiros se identificassem com elas. ${ }^{354}$

Em suas palestras e discursos, assim como em reuniões internas na agência, Rowan sempre fazia questão de citar Murrow e Kennedy, principalmente quando usava o ditado de Murrow que a verdade era a maior arma americana ("Truth as a weapon"), mas sempre deixava claro que a verdade tinha que ser contada na perspectiva americana: "Eu pretendo que a agência conte a verdade e coloque a sua perspectiva... Talvez você tenha que falar um pouco sobre o passado, quais as expectativas futuras e qual é o papel do governo federal... essa é toda a verdade". 355

Apesar do maior alinhamento com o Departamento de Estado buscado por Rowan, no início do governo Johnson, as frentes de ação da USIA continuaram as mesmas da época de Kennedy, tendo o contato pessoal com grupos-alvo como prioridade, além do Voice of America, televisão e filmes. ${ }^{356}$ Isso se dava por meio de atividades dos postos locais, diálogo dos funcionários dos USIS com lideranças de cada país e acompanhamento constante da mídia e da opinião pública com as pesquisas.

Porém com a morte de Kennedy, a herança da Revolução cubana, da crise dos mísseis, e da Baía dos Porcos, a presença americana na América Latina tornou-se ponto de honra para o governo Johnson. Para a USIA de Rowan isso se traduzia como mudança importante: o continente americano como prioridade. Em 11 de março de 1964, seu segundo mês na USIA, Rowan explicitava a recomendação presidencial de forma clara, em discurso a embaixadores latino-americanos: "A América Latina está muito no meu pensamento nesses dias, particularmente levando em consideração ao aviso do Presidente Johnson de que nenhum trabalho é mais

354 Documento 32: "1964: Rowan - USIA's most important function is furthering U.S. Foreign Policy by influencing foreign attitudes”.

355 Documento 30: "1964-5: Rowan insists truth must be placed in perspective".

356 Documento 31: "1964: Rowan - rates personal contact, radio E TV in order named as best media for influencing foreign opinion". 
importante para esta geração de americanos do que a nossa em nosso hemisfério". ${ }^{357}$

Essa prioridade no continente latino-americano pode ser percebida pelo aumento abrupto de funcionários da USIA nos primeiros anos da década de 1960. Em 1959, a USIA tinha 140 funcionários americanos e 664 funcionários locais nos postos latino-americanos. Em março de 1964 a agência aumentou para 214 funcionários americanos e 790 locais nos USIS da América Latina. ${ }^{358}$

Isso também foi observável no aumento do orçamento da USIA para a região, de US\$ 5,4 milhões em 1959, para US\$ 9,2 milhões em março de 1964, com um pedido adicional de US\$1,03 milhão para 1965. De 1959 a 1964, também foram abertos novos postos locais e 4 novos centros de leitura. ${ }^{359}$

O foco entre os grupos latino-americanos continuaram sendo os estudantes e os sindicatos. Para isso, em 1964 a USIA enviou 9 novos assessores de "informação", especificamente focados no mundo do trabalho (Labor Information Officers) "utilizar técnicas de informação para construir o apoio para soluções democráticas para os problemas latino-americanos, particularmente as soluções que fazem parte do Aliança para o Progresso". ${ }^{360}$ E para a área estudantil, a USIA escalou, no mesmo ano, seis novos "Students Affairs Officers" (que trabalhavam nos USIS latino-americanos) e 25 bolsistas, estudantes americanos, instalados nos centros binacionais. ${ }^{361}$

Segundo Rowan, os information officers para os mundos do trabalho e estudantil foram escalados principalmente para os postos locais e centros binacionais mais importantes do continente. ${ }^{362}$

Em 1964, a USIA mantinha 119 centros binacionais em 19 países latino-americanos, onde eram dadas aulas de inglês, palestras

357 Documento 62: "Rowan's speech to L.A. Ambassadors, mar 11, 1964".

358 Idem.

359 Idem.

360 Idem.

361 Documento 62: "On the Propaganda War: Latin America... - Printing Week Convention, Minneapolis, Minn., February 21, 1964. “.

362 Documento 62: "Rowan's speech to L.A. Ambassadors, mar 11, 1964”. 
sobre temas variados, cursos de cultura e literatura americana, com exibições de arte, filmes e shows. A agência também contava com 11 bibliotecas e information centers na região, onde eram promovidas exibições sobre a Aliança para o Progresso, grandes feitos americanos no espaço ou sobre as promessas descumpridas por Fidel Castro em Cuba. ${ }^{363}$

Outra preocupação era a produção, tradução e distribuição de livros americanos, subsidiados pela USIA, nas áreas de educação, trabalho e religião, que mostrassem ao público latino-americano o "senso de identidade de interesses e valores entre os EUA e a América Latina, e demonstrar que o comunismo-castrista não é a resposta para os problemas sociais e econômicos do hemisfério ocidental". ${ }^{664}$

Só no ano de 1964, a USIA tinha subsidiado cerca de 3,5 milhão de cópias de mais de 323 livros para o continente latino-americano. ${ }^{365}$ No mesmo ano, a USIA também pretendia distribuir mais de 37 milhões de revistas de histórias em quadrinhos em todo subcontinente, por meio de seu centro regional de publicações instalado no México.

As atividades dos grandes meios de comunicação também se multiplicaram, na América Latina, em 1964. Com a inauguração do centro de transmissão em Greenville, em 1963, o sinal do VOA e dos programas de rádio da USIA era dominante na região. Eram exibidos programas gravados nos EUA e nos postos locais em estações de rádio comerciais latino-americanas. Cerca de 11 mil horas semanais de programas de rádio da USIA eram transmitidas na América Latina, em mais de 1.500 estações locais.

Em 1964, a agência de notícias da USIA também transmitia cerca de 10 mil palavras por dia (que eram traduzidas para o português pelo posto local da USIA no Rio de Janeiro) para os jornais e revistas da região.

Outra frente de ação da USIA para atingir as massas latino-americanas era a televisão, com uma audiência anual de cerca de

363 Idem: "On the Propaganda War: Latin America... - Printing Week Convention, Minneapolis, Minn., February 21, 1964. “.

364 Idem.

365 Idem: "Rowan's speech to L.A. Ambassadors, mar 11, 1964". 
10 milhões de pessoas no continente. ${ }^{366} \mathrm{O}$ carro-chefe da USIA TV continuava sendo o "Panorama Panamericano", além de continuar exibindo os programas especiais sobre temas de interesse de grupos prioritários latino-americanos, como a reforma agrária, a Aliança para o Progresso, ou reportagens que desmitificavam a revolução cubana, como a que mostrou armas cubanas escondidas na Venezuela, em $1964 .{ }^{367}$

A produção audiovisual da USIA para o continente também tinha um documentário chamado Horizons ${ }^{368}$ exibidos nas salas de cinema comerciais latino-americanas, também exibidos em projetores cedidos pela USIA em escolas, universidades, igrejas e sindicatos. ${ }^{369}$

Após a sua morte, Kennedy continuou sendo a grande estrela dos filmes da USIA, agora como espécie de mártir americano, que teria seu legado garantido por Johnson. Um dos filmes produzidos pela USIA e exibidos na região era o documentário de $1 \mathrm{~h} 30 \mathrm{minu}$ tos chamado John F. Kennedy: years of lightning, Day of drums, que contava a saga americana, que não poderia ser abalada mesmo com o assassinato de JFK. O filme, narrado por Gregory Peck, começava com os dizeres:

Foi verdade que o Presidente foi morto. [...] Mas também foi verdade que o assassino não atingiu o seu alvo, porque ele queria que John Kennedy morresse, e isso ele não conseguiu fazer... porque nenhum homem pôde levar anos de Luzes (Lightning), com um único dia de tambores (Drums). ${ }^{370}$

Outro filme lançado pela USIA na América Latina em março de 1964 foi o The President, produzido pela USIA em apenas quatro

366 Id.: "On the Propaganda War: Latin America... - Printing Week Convention, Minneapolis, Minn., February 21, 1964. “.

367 Documento 62: "Rowan's speech to L.A. Ambassadors, mar 11, 1964”.

368 Idem.

369 Idem: "On the Propaganda War: Latin America... - Printing Week Convention, Minneapolis, Minn., February 21, 1964. “.

370 Documento 51: "Fine Kennedy Film, - Only for Abroad/ NYTimes/Judith Crist". 
semanas e que tinha a missão de mandar a seguinte mensagem para todos os países do mundo:

[...] até em momentos de maior tragédia, há a continuidade na tradição democrática dos EUA; da que o homem que assumiu a presidência, Lyndon B. Johnson, é um homem de grande capacidade e experiência e que ele continuará a guiar os EUA em um rumo estável; e que em seu novo posto ele tem o apoio do povo americano.... Continuemos. ${ }^{371}$

A USIA de Johnson/Rowan tinha a clara visão de que, apesar de historicamente alinhada aos EUA, a atenção da agência tinha que ser redobrada em países amigos, ${ }^{372}$ como os latino-americanos, principalmente após a Revolução cubana e para isso também formaram iniciativas pontuais para defender alguns dos interesses do país. Uma das principais preocupações da USIA era ajudar a diminuir a rejeição aos EUA e às empresas americanas na região; e, para isso, uma força-tarefa foi formada. ${ }^{373} \mathrm{Em}$ um evento a portas fechadas com empresários americanos no Westchester Country Club de Nova York, ${ }^{374}$ Rowan desenhou um plano conjunto de longo prazo para ações conjuntas das empresas americanas e USIA na América Latina, que melhorassem a imagem das empresas e do país na região.

Para Rowan, se o plano piloto, na Colômbia, desse certo, a iniciativa se espalharia por todo subcontinente. Segundo ele:

Uma equipe composta por representantes da indústria e da USIA acabou de concluir um estudo na Colômbia e agora está

371 Documento 51: "1963-4: Stevens - Documentary on "The President" completed in four weeks/ H: USIA Approp '65, p.397 (4 mar 64)”.

372 Documento 30: "1964: Rowan - just as important to keep goodwill of a friend as to win goodwill of a neutral/USIA Approp '65, p 1500 (July 1)”.

373 Bogart (1995, p.115) descreve a importância da cooperação de empresas e USIA.

374 Documento 62: "Rowan's speech to L.A. Ambassadors, mar 11, 1964”. 
escrevendo uma proposta de plano conjunto de ações indústria-relações públicas para aquele país. Se isso prosperar, talvez estejamos no limiar de uma cooperação crescente entre o governo dos EUA e a indústria em muitos países latino-americanos, no campo das relações públicas. ${ }^{375}$

No começo de 1964, Rowan também anunciava outras ações conjuntas em projetos específicos, em pontos que requeriam maior atenção na região. Um deles, com a USAID, era especificamente para a região nordeste do Brasil. Para isso, a USIA enviou assessores de relações públicas para o local: "Nós nomeamos assessores de relações públicas (public affairs advisers) para trabalharem com projetos da AID em algumas regiões: o projeto do Nordeste do Brasil, e o ROCAP, na América Central".376

A postura mais intervencionista, não tão sutil, de Johnson na América Latina ${ }^{377}$ e a falta de preocupação direta do Presidente com as políticas de informação (em comparação a seus antecessores Eisenhower e Kennedy), apresentaram-se como um ponto de inflexão na história da USIA, com a diminuição de sua importância no interior do governo e na opinião pública norte-americana. Depois do governo Johnson, reeleito em 1964, nunca mais a USIA teve a mesma importância para os Presidentes estadunidenses.

Segundo o jornalista Edward W. Barrett, que trabalhou em alguns dos antecessores da USIA (ex- OSS, OWI e Assistant Secretary for Public Affairs de Truman), Johnson não dava a mínima importância às atividades de informação. Segundo ele: "Em uma conversa com Eisenhower nos primeiros tempos da USIA, ele me contou que gostaria de ter aumentado o dinheiro para ela porque era

375 Idem.

376 Idem. A ação da USIA/USAID no nordeste brasileiro será retomada, com maior profundidade no terceiro capítulo.

377 Sellers; May; Mcmillen (1990, p.405) chegam a comparar a postura de Johnson em relação à América Latina como a volta do método do Big Stick de Theodore Roosevelt. 
uma força e tanto durante a Guerra Fria . [O Presidente Lyndon] Johnson nunca levou isso a sério" (Bogart, 1995, p.xvii). ${ }^{378}$

Em julho de 1965, depois de um pouco mais de um ano de assumir, Carl Rowan renunciou a seu posto na direção da USIA para voltar à sua carreira privada. ${ }^{379} \mathrm{O}$ Presidente Johnson, recém-eleito, cada vez mais assumiu o posto com suas próprias características e continuaria a aprofundar a presença militar americana no Vietnã e em outras regiões do mundo, sem levar em consideração a opinião pública interna e externa como fator determinante de sua política externa.

378 Barrett também é autor de um importante livro sobre a história da política de informação americana: "Truth is Our Weapon", de 1953 (citado como referência pela maioria dos estudiosos americanos do tema desde então).

379 Documento 62: "The White House, Exchange of letters between President Johnson and Carl T. Rowan, July 1965". 


\section{$\stackrel{2}{\text { A USIA NO BRASIL DE } 1953 \text { A } 1964}$}

É indispensável que os USIS sejam imponderados para não terem mais uma posição passiva, defensiva no Brasil, assumindo a ofensiva da propaganda. É urgente, o objetivo principal deve ser colocar a opinião pública brasileira de volta para onde estava quando clamava por assumir a aliança com os EUA durante a Segunda Guerra Mundial. Quando isto for atingido, os objetivos dos USIS poderão ser cumpridos e as metas da política dos EUA, facilitadas. ${ }^{1}$

William A. Wieland - Public Affairs Officer no Brasil, em relatório interno ao embaixador americano no Rio de Janeiro, em abril de 1953, três meses antes da criação da USIA.

No pós-2 ${ }^{\text {a }}$ Guerra, a estratégia da política externa americana no Brasil pretendia resgatar o alinhamento entre os países logrado durante a batalha. Para os americanos, no contexto de Guerra Fria que se formava, o Brasil era visto como ponto chave da América Latina e, por isso, os novos órgãos de informação que se formavam durante o

1 Documento 64: “1954-55 IIA Prospectus for Brazil/April 1953”. 
governo Truman (como o IIA) tinham especial atenção ao país. Haines (1989, p.162) deixava clara a posição do governo americano no pós-guerra, que se estendia pelos anos 1950: "Por causa da importância estratégica do Brasil e de sua posição dominante na América Latina, ele tornou-se um ponto focal para os programas culturais e de informação dos EUA".

Desde o governo Truman, a proposta de ação no Brasil visava expandir a cooperação econômica ${ }^{2}$ em conjunto com as atividades de informação, principalmente por meio dos grandes meios de comunicação de massa, como o rádio, os jornais e revistas, a televisão e os filmes (Haines, 1989, p.190). Aproveitando a estrutura física já consolidada no Brasil, crescente desde a década de 1930, com os centros binacionais espalhados pelo país, também foi intensa a promoção do inglês, além da produção de materiais gráficos para setores como sindicatos, igrejas, universidades e associações, da distribuição de livros para as bibliotecas e a realização de palestras, exposições e feiras.

Com a eleição de Eisenhower, a aproximação pessoal desejada por Rockefeller no final de 1952 não foi concretizada como esperado. Com o suicídio de Vargas em agosto de 1954, a imagem americana sofreu graves danos na opinião pública brasileira.

Para o primeiro diretor da USIA, Theodore Streitbert, a luta era desigual na América Latina, já que a forte presença comunista minava a reputação americana na região. Para ele, com a morte de Vargas, a manipulação do conteúdo da carta-testamento do Presidente brasileiro incentivada pelos comunistas colocava os EUA como vilão. Por isso se explicavam as depredações dos USIS e escritórios do governo americano em cidades brasileiras:

Os comunistas nunca perdem a oportunidade de aproveitar das situações. O suicídio do Presidente Vargas, por exemplo, foi utilizado amplamente para criar hostilidade com relação aos EUA.

2 Mais sobre a cooperação econômica, técnica e informacional no Brasil em OSGOOD (1968, p.145). 
[...] Eles aproveitaram a carta suicida e agora já estão chamando de Magna Carta do Brasil, destacando as referências ao "capital estrangeiro", sendo que o capital estrangeiro no Brasil é capital do EUA. As manifestações após a morte do Presidente Vargas foram dirigidas pelos comunistas contra os Estados Unidos. Manifestantes invadiram o consulado em Porto Alegre, jogaram móveis e luminárias para fora da janela, quebraram todos os tipos de coisas. [...] É impossível equiparar os 60 mil comunistas no Brasil, os 40 mil no Chile, os 15 mil no Uruguai, os 20 mil na Venezuela, etc., [...] a maioria deles ilegal, mas muito ativos. ${ }^{3}$

A notícia da morte de Vargas também atingiu o USIS de Belo Horizonte, logo após a notícia do suicídio ser veiculada, no mesmo dia 24 de agosto de 1954. Portas e janelas foram quebradas, mesas das bibliotecas foram viradas, com livros e equipamentos destruídos. ${ }^{4}$ As depredações aos USIS continuaram no Brasil durante a década de 1950. Em julho de 1958, logo após a visita do vice-Presidente Nixon à América Latina, ${ }^{5}$ o Centro Binacional de Fortaleza foi danificado por protestos de pichadores, que escreveram palavras contra os EUA nas paredes do prédio e jogaram as latas de tintas, quebrando as suas vidraças. ${ }^{6}$

Como vice-Presidente de Eisenhower, Nixon foi um dos emissários mais dedicados ao bom reestabelecimento da imagem americana na região. Seguindo orientações de Nelson Rockefeller, então assessor especial na Casa Branca, Nixon esteve presente no Brasil logo após a posse de Juscelino Kubitschek, em fevereiro de 1956.

No relatório interno "pessoal e confidencial" de Rockefeller ${ }^{7}$ que seria enviado a Eisenhower (após a eleição de JK, em dezembro de

3 Documento 45.

4 Documento 65.

5 O Documento 66 mostra pesquisas de opinião pública da USIA sobre as visitas de Nixon a Buenos Aires, Caracas e Lima na mesma ocasião.

6 Documento 65.

7 Documento 67. Apesar de haver escrito o relatório, não foi necessário enviar a carta para convencer o Presidente da mensagem. A carta estava riscada a lápis, 
1955), Juscelino era descrito como um aliado importante dos EUA, pela sua amizade com Nelson, pela sua inclinação para a abertura do mercado brasileiro para o desenvolvimento econômico e principalmente pelo seu anticomunismo declarado: "O Presidente eleito do Brasil Juscelino Kubitschek, passou a ser o meu amigo. ... Sob sua liderança, parece-me que há uma grande oportunidade para que as relações entre Brasil e EUA sejam muito mais próximas como há muito tempo não são". ${ }^{8}$

Com a mesma orientação que havia dado em relação a Vargas, Nelson Rockefeller indicava a Eisenhower que o contato pessoal era fundamental com os brasileiros, para que se desenvolvesse uma boa relação entre os países:

[...] Como muito brasileiros, ele é altamente personalista em seus sentimentos e por causa disso, estou tomando a liberdade de escrever esta nota para fazer uma sugestão relacionada à sua posse, que está próxima.... Eu tenho a sensação que, com base no grande sucesso de suas turnês de boa "vizinhança"" anteriores, seria possível que o vice-Presidente Nixon chefiasse a delegação da posse de Kubitschek no próximo mês, onde ele seria muito bem recebido no Brasil e ajudaria enormemente a começar de maneira forte o seu mandato. ${ }^{10}$

Desde sua campanha, Kubitschek era visto pela Casa Branca como garantia de bons negócios e de luta contra o comunismo no país "ponto focal" da América Latina. Em relatório interno da Casa Branca de outubro de 1955, Rockefeller descrevia o plano de metas, a aproximação com os EUA e o anticomunismo de Juscelino:

Kubitschek mencionou seus planos de promover um grande desenvolvimento da economia brasileira... ele disse que os EUA era

com a seguinte frase, escrita à mão (possivelmente pelo próprio Rockefeller):

"Not sent: VP is going to Brazil".

8 Documento 67.

9 "goodwill tours".

10 Documento 67. 


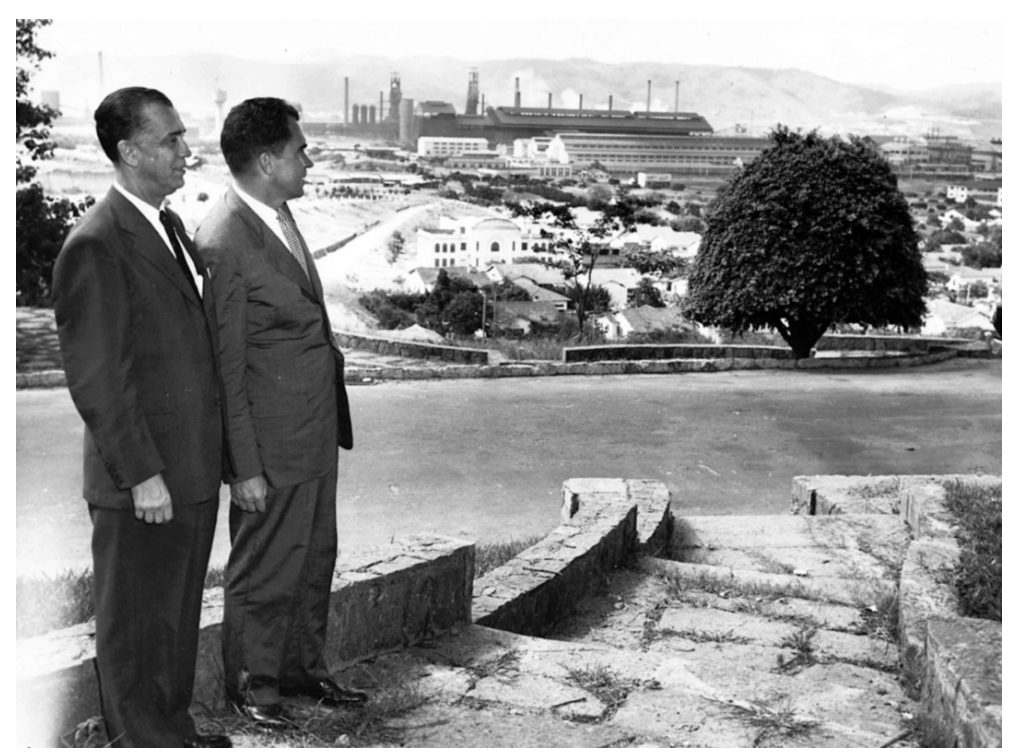

Figura 31 - Em 1956 Nixon visita a Companhia Siderúrgica Nacional em Volta Redonda, um dos produtos da boa relação entre os países durante a $2^{\mathrm{a}}$ Guerra que o Vice-presidente americano tinha vindo resgatar com JK.

o único país que poderia auxiliá-lo a aprofundar seus planos econômicos... Dunn teve uma impressão muito favorável do estilo de Kubitschek, sua autoconfiança e vitalidade. Kubitschek relatou que ele não era comunista e que não permitiria que comunistas fossem ativos no seu governo. ${ }^{11}$

O Brasil de Juscelino, em sua acelerada expansão econômica, era um ótimo exemplo de aprofundamento das boas relações de amizade, cooperação econômica (e informacional) com os EUA (Bandeira, 1973, p.306). ${ }^{12}$ Isso também se refletia na mudança dos hábitos brasileiros, que durante esses anos incorporaram ao Brasil moderno de JK alguns costumes americanos. Segundo Bandeira

11 Documento 67.

12 O autor descreve a negociação de Dulles com JK, em 1956, para estabelecer a cooperação e troca de informações entre os países, visando o combate ao comunismo. 
(ibidem, p.316), isso podia ser visto na nova linguagem direta dos jornais, no uso da publicidade, na incorporação dos eletrodomésticos nas casas, nos supermercados e no tipo de entretenimento do brasileiro das grandes cidades.

Um relatório interno da USIA e do Departamento de Estado sobre as Brazilian attitudes, em 1955 $5^{13}$, enviada à Casa Branca, mostrava que o país passava por um período de profundas mudanças sociais e econômicas na segunda metade do século XX, tal qual os EUA haviam passado na última metade do século XIX. Com isso, novos grupos emergentes, como industriais, classe média e trabalhadores tinham um papel fundamental nos próximos anos.

Segundo o mesmo relatório, o principal tema de interesse nacional brasileiro era o desenvolvimento econômico, muito mais do que os temas internacionais como a Guerra Fria. Com base em pesquisas qualitativas e quantitativas feitas na primeira metade da década de 1950, o relatório ainda apresentava o Brasil como uma potência em expansão que ainda não tinha capacidade de assumir compromissos externos, pois para a maioria da população (e governo) eram muito mais relevantes os problemas sociais e econômicos nacionais.

É esse o contexto em que o Brasil dos anos 1950 posicionava-se diante dos EUA. As diversas ações implementadas pela USIA de Eisenhower, durante os anos 1960, eram sempre relacionadas a informações que divulgassem a cooperação para o desenvolvimento econômico entre os dois países ou os EUA como modelo de democracia que aliava desenvolvimento e liberdade.

A visita do próprio Eisenhower ao Brasil em 1960, com imensa comoção popular no Rio de Janeiro, coroava as boas relações dos dois países durante o governo Juscelino. A Figura a seguir, capa de um material do programa People-to-People, mostrava como que, também para a USIA de Ike, o Brasil era exemplo de país amigo dos EUA.

13 Documento 63. 


\section{JOIN NOW \\ IN THE \\ ETTERS FROM AMERICA CAMPAIGN}

Letters are an opportunity for the individual American to spread the truth about America.

Today the United States is challenged to make known the truth about its life, its aims and faith. Many of the things said about us overseas are based on false impressions or hostile propaganda. Truth is freedom's most powerful ally. Letters from America can do much to make the truth prevail.

Letters are an opportunity for the individual American to work for better world relations.

Our country is fortunate in having many million citizens with relatives and friends in all parts of the world. Every letter from America helps in a small but important way to strengthen international friend. ship and goodwill.

Letters from America, a project of the American Council for Nationalities Service, was launched in 1950. By 1960 the number of letters Americans were sending overseas had risen to 400 million a year, an increase of 140 million.

The Letters From A merica campaign is part of the American Council's broad national and international program. Among other activities, the American Council assists immigrants to adjust to American life and become fully participating citizens. It works for wider knowledge and appreciation of America's democratic institutions and ideals. It promotes people-to-people contacts and better international understanding. It has member agencies in 40 cities. which are centers of service and fellowship for all nationalities. For further information about the LETTERS From AMERica program and the work of the American Council, write to:

\section{AMERICAN COUNCIL FOR}

NATIONALITIES SERVICE

20 West 40th Street, New York 18, N.Y.
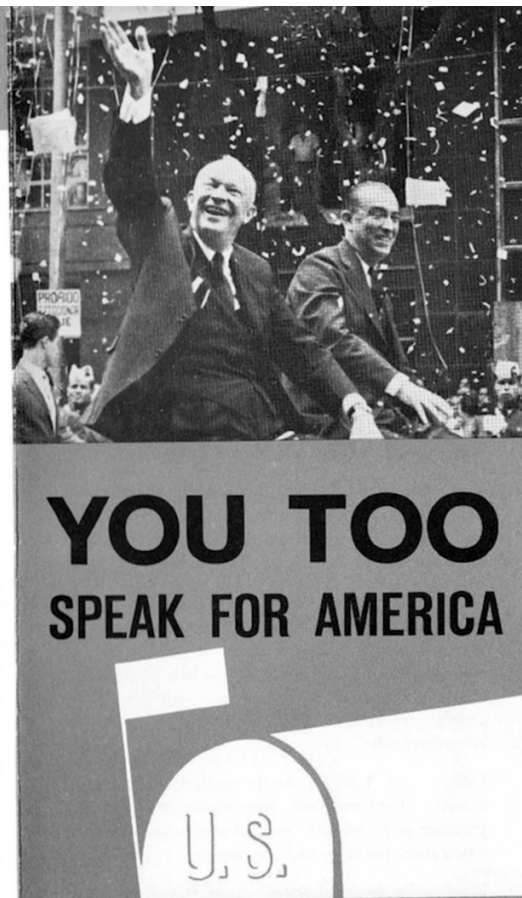

Nothing is more dangerous to our cause than to expect America's message to be heard if we don't bother to tell it.

-DWight D. EisenHower

\section{LETTERS FROM AMERICA}

Figura 32 - Visita de Eisenhower ao Brasil em 1960, usada como ilustração de material da USIA sobre a amizade com outros povos e o comitê de cartas do People-to-People.

O contexto favorável das relações entre os países começaria a mudar junto com a mudança de década. A revolução cubana em 1959 e as eleições de JFK e Jânio/Jango no final de 1960 mudaram completamente o panorama anterior. Com os novos governos a partir de janeiro de 1961, as percepções em relação ao outro e as estratégias de informação da USIA no Brasil também mudaram. 
Como visto, à medida que as crises políticas com Cuba se aprofundaram nos primeiros anos da década de 1960, garantir uma opinião pública favorável no Brasil era fundamental para que os EUA contivessem o crescimento do comunismo em seu "hemisfério". Para isso, o governo Kennedy deu especial atenção a grupos prioritários no país, principalmente estudantes e trabalhadores.

Este terceiro capítulo pretende mostrar os principais eixos de ação da USIA no Brasil durante os governos Eisenhower e Kennedy/Johnson até o final do governo João Goulart, fim esse provocado pelo Golpe Militar em $1^{\circ}$ de abril de 1964. São abordadas as pesquisas, a estrutura física no País, a relação com a mídia e diferentes setores da sociedade brasileira e a estratégia de divulgação do Golpe feita pela USIA, na ocasião.

\subsection{O Departamento de Pesquisa da USIA e o mapeamento da opinião pública}

Depois da criação da USIA em 1953, os Departamentos relativos à informação e a política externa anteriormente existentes em diversas agências do governo fundiram-se na nova agência. Esse foi o caso do Departamento de Pesquisa, um dos mais fundamentais Departamentos da USIA, responsável por alimentar a agência (e o Presidente americano) de informação atualizada sobre os principais temas de interesse relacionados à opinião pública internacional, da mídia e das atividades dos postos locais. ${ }^{14}$

$\mathrm{O}$ antigo Office of Evaluation, anteriormente ligado ao IIA e que pesquisava os temas relativos às políticas de informação, foi fundido com as organizações responsáveis especificamente pelas pesquisas relacionadas aos serviços de mídia no exterior (como as do Voice of America, que chegou a ter uma equipe com 150 pessoas) e com as funções do Coordinator of Psychological Intelligence, responsável pelas análises do setor de inteligência. Da fusão desses três serviços

14 Documento 70. 
nasce no seio da USIA o Office of Research and Evaluation (em 1953), transformado em Office of Research and Intelligence (em abril de 1954). ${ }^{15}$

Em 1959, uma proposta interna de mudança de concepção nas atividades de pesquisa da USIA (que deveria deixar de pesquisar temas relativos ao comunismo para se dedicar à informação mais ampla e qualificada dos países) mudou novamente o nome do Departamento para Office of Research and Analysis. ${ }^{16}$

O Departamento continuava os serviços que vinham pelo menos desde a $2^{\text {a }}$ Guerra, utilizando métodos de pesquisa de mercado (quantitativa e qualitativa) e metodologias das ciências sociais para melhor conhecer o público e a forma de atingi-lo. ${ }^{17}$

Mesmo com a readequação dos serviços e redução dos funcionários e orçamentos para pesquisa, a agência, já em 1953, começou a contratar serviços de pesquisa aplicada para medir a eficácia dos programas da rádio WRUL na América Latina. Essa pesquisa, como muitas da USIA, era contratada por um instituto com sede no Empire State Building, em Nova York, chamado International Public Opinion Research Inc.

Com a morte de Vargas em agosto de 1954, e os ataques aos USIS em Porto Alegre e Belo Horizonte, o Departamento de Pesquisa (e inteligência) produziu um informe confidencial específico sobre a situação do comunismo no Brasil. ${ }^{18}$ Esse documento fora dirigido à USIA, à CIA, ao Departamento de Estado, ao Departamento de Defesa e ao Operations Coordinating Board (OCB).

Enviado em 22 de outubro de 1954, o relatório se dividia em duas grandes partes. A primeira resumia o contexto e a estratégia da Intentona Comunista de 1935, mostrando as conexões internacionais e a participação de Prestes (que havia sido treinado durante quatro

15 Documento 69.

16 Documento 69.

17 Como os métodos desenvolvidos pelos cientistas sociais Leo Lowenthal e Paul Lazarsfeld, que chegaram a coordenar a equipe de pesquisa do VOA. Mais sobre o uso dos métodos da "propaganda científica", em Bogart (1995, p.xx).

18 Documento 72. 
anos na URSS e era membro do comitê executivo do Partido Comunista Soviético), e suas conexões com outras lideranças comunistas sul-americanas (da Argentina e Uruguai) e europeias. ${ }^{19}$

Essa primeira seção terminava mostrando as raízes do movimento comunista brasileiro desde 1926, com base em um artigo do comunista Octávio Brandão, daquele ano, no qual comparava o trabalho dos comunistas no Brasil como o de formigas operárias. A segunda parte era baseada em um rascunho de um programa do Partido Comunista do Brasil (Draft Program) em 1954, que mostrava as táticas do movimento no País. ${ }^{20}$

Encomendado pelo USIS da Embaixada americana no Rio de Janeiro, o relatório tinha como motivação explícita preparar o posto local para ação contra as articulações políticas pré-eleitorais de quadros do Partido Comunista Brasileiro, que tentava ampliar seu leque de alianças, também entre os partidos não comunistas brasileiros, como o PTB de Vargas:

O material presente neste relatório foi preparado para responder a uma demanda do Public Affairs Officer no Rio de Janeiro, por informação sobre os aspectos internacionais e subversivos do comunismo no Brasil. Tal informação foi pedida pelo USIS no Rio para neutralizar as atividades pré-eleitorais do Partido Comunista do Brasil, principalmente seus esforços para fazer alianças com partidos não comunistas brasileiros, especialmente com o partido do próprio Vargas, o Partido Trabalhista Brasileiro. ${ }^{21}$

O material se apresentava como confidencial principalmente por causa das razões que explicavam sua motivação, isto é, o trabalho do USIS no Rio para influenciar as articulações políticas internas, minando a estratégia comunista: "O relatório leva a classificação CONFIDENCIAL por causa das explicações mencionadas acima,

19 Idem.

20 Idem.

21 Documento 72. 
sobre as causas e comentários do documento, de acordo com as variações das estratégias e táticas comunistas". ${ }^{22}$

Toda a estratégia comunista para o Brasil era exposta com base em reportagens locais (uma delas, do Correio da Manhã, com citações do chefe de polícia Filinto Müller) e com base em discursos de Luiz Carlos Prestes. O foco comunista, segundo o relatório, se concentrava nos militares, intelectuais, estudantes e trabalhadores das indústrias, nas grandes cidades, e nos trabalhadores rurais no campo. $^{23}$

A conclusão do informe mostrava uma mudança de posição dos comunistas brasileiros, em relação a Vargas, depois de seu suicídio. Antes de sua morte, era chamado de "lacaio do imperialismo" e após a sua morte, esses tentavam se aproximar do PTB, voltando a sua oposição à figura de Café Filho. ${ }^{24}$

Em seu fim, o relatório alertava que em novembro de 1954, os comunistas brasileiros apresentavam-se como um partido nacional, mas assim como tentaram fazer em 1935, visavam a tomada do País pelo comunismo internacional: "Quando o PCB entrou para ilegalidade durante o governo Dutra em 1947, era porque o partido seria hostil ao governo democrático do Brasil e obedecia a ordens de uma potência externa. Não há razão para acreditar que essas acusações contra o PCB não são mais verdadeiras". ${ }^{25}$

O ano de 1955 foi marcado pela sofisticação dos instrumentos de pesquisa nas áreas de informação e estudos "psicológicos" de outros países. Essas iniciativas também tiveram impactos na USIA do Brasil, que estabeleceu uma equipe local própria para as investigações no País. Localizada no USIS do Rio de Janeiro a partir de setembro daquele ano, o Departamento agia em parceria com o governo e indústria locais, instituições educacionais e institutos de pesquisa social locais.

22 Documento 72.

23 Documento 72.

24 Documento 72.

25 Documento 72. 
O posto de pesquisa no Brasil propunha desenvolver atividades periódicas de pesquisa sobre as bibliotecas, estudos de mídia, produzir publicações sobre a opinião pública, a imprensa e estudos sociais feitos sobre o Brasil, encomendados ou não pela USIA. ${ }^{26}$

Outra novidade importante daquele ano foi formação de um Departamento de Pesquisa próprio para o Departamento de Defesa, que se relacionaria com o da USIA, mas cuidaria especificamente de estudos "psicológicos" e utilizaria táticas "não-convencionais", como participação de agentes em movimentos políticos em outros países, de caráter "coberto", como em guerrilhas, fugas e subversão contra Estados estrangeiros "hostis". ${ }^{27}$ Para isso, poderia se utilizar de armamentos, bombas, transporte aéreo e atividades de contra-inteligência.

É também a partir de 1955 que começaram a ser produzidos periodicamente, a cada 4 ou 6 meses, os "Barômetros", ${ }^{28}$ iniciativa mundial da USIA para medir as opiniões políticas das diversas regiões em relação aos EUA e temas correlatos. Para a região, o chamado "Latino Barômetro" daquele ano pesquisava sobre a opinião brasileira com relação aos EUA e com as revoltas com teor comunista na Guatemala, utilizando-as para cruzar opiniões sobre o programa Atoms for Peace e de entretenimento, como a audiência da rádio WRUL. ${ }^{29}$

Os resultados da pesquisa, que não era encomendada oficialmente pelo governo americano, eram contratados formalmente também pelo International Public Opinion Research Inc. $/ \mathrm{NY}^{30} \mathrm{e}$ enviados pela USIA para o Departamento de Estado, a CIA, as Forças Armadas e à equipe da Casa Branca.

Segundo o Latino Barômetro de 1955, o Brasil se mostrava favorável à imagem americana e às suas intervenções na América Latina,

26 Documento 73.

27 Documento 73.

28 Documento 73.

29 Documento 73.

30 Documento 71: "ZP 5303, Radio Listening, multi-Latin American, 6 Latin American cities radio listening + political atitudes, mar. 1955". 
mas relativamente era o país latino-americano com aprovações mais baixas aos EUA: $60 \%$ dos brasileiros tinham uma boa imagem dos EUA e somente $14 \%$ eram favoráveis às intervenções militares americanas na região. Além disso, apesar de alta, o País apresentava a menor rejeição à URSS na América Latina, isto é, 58\%. ${ }^{31}$

Para a realização das pesquisas, eram contratados institutos de pesquisa locais. No Brasil, para o ano de 1955, foram contratadas a representação brasileira da "McCann-Erickson Publicidade S.A.", o "Instituto Brasileiro de Opinião Pública e Estatística”, o "Instituto de Pesquisa de Opinião e Mercado", os três no Rio de Janeiro, e a Escola Livre de Sociologia e Política, de São Paulo. ${ }^{32}$

Outros estudos sobre temas específicos do Brasil também começaram a ser realizados, como o que avaliava a participação comunista na campanha de nacionalização de petróleo desde $1947 .{ }^{33}$ Essa seria articulada pelo Partido Comunista, por alguns setores do operariado e pela União Nacional dos Estudantes, comandada também por comunistas.

Para o estudo, ${ }^{34}$ o desenvolvimento da exploração do petróleo no Brasil só poderia ser feito pela exploração de empresas privadas americanas, que eram impedidas por um discurso nacionalista, com fundo comunista, como era explorado por reportagens da época em jornais brasileiros como "O Estado de S. Paulo" e o "Diário de Notícias”. No relatório da USIA, eram usadas como referência notícias publicadas nos jornais O Globo, O Jornal, Jornal do Brasil e Diário Carioca, denunciando uma suposta infiltração comunista no Centro Nacional de Estudos e Defesa do Petróleo e da Economia Nacional (CNEDPEN).

Assim como esse estudo, algumas das pesquisas específicas realizadas pela USIA no Brasil interessavam também a empresas

31 Documento 66: "LA-1, Some basic political and economic attitudes in six Latin American cities, Report \# 1, June 29, 1955”,

32 Documento 12.

33 Documento 72: "IS-3-55, Communist attempts to obstruct development of petroleum industry in Brazil, January 28, 1955”.

34 Idem. 
americanas, e por isso eram financiadas, em segredo, por corporações que tinham algum interesse econômico no Brasil.

Em correspondências internas entre a USIA Washington e o USIS no Rio de Janeiro, no entanto, são identificadas algumas pesquisas da USIA no Brasil financiadas pela Esso do Brasil, como as encomendadas pela USIA em 1954 e 1955. Resultados de partes dessas pesquisas, principalmente a que mostravam apoio de partes do governo e da sociedade brasileira à exploração privada do petróleo, foram divulgadas em reportagem do New York Times (porém sem que se revelasse a fonte da pesquisa): "As pesquisas patrocinadas pela Esso - houve duas, uma em 1954 - a outra na primavera de 1955, base para a notícia do New York Times, indica uma pequena diminuição da dependência do governo pelo desenvolvimento do petróleo". 35

Em 1956, a USIA (por meio do então chamado International Research Associates, Inc., ainda no mesmo endereço - Empire State Building) começava a contratar pesquisas de opinião política, econômica e hábitos de mídia mais aprofundadas, acrescentando cidades mais afastadas dos grandes centros urbanos do Brasil, em Estados como Amazonas, Acre, Rio Branco, Mato Grosso, Amapá e Goiás, o que não acontecia nas primeiras pesquisas. ${ }^{36}$

Ao mesmo tempo em que se mediam as expectativas e o contentamento em relação aos EUA, também eram levantadas, nos mesmos grupos, as audiências dos principais programas de rádio produzidos pela USIA, como "Você se lembra", "Comentários de Al Neto", "Os Vencedores da Vida", "Noveleta Panamericana”, "Hit Parade" e "Clube do Disco". ${ }^{37}$

No geral, durante as pesquisas dos anos 1950, a opinião pública brasileira era favorável à tentativa de aproximação econômica com os EUA, mas apontava também uma maior rejeição em relação aos outros países americanos, sobretudo à intervenção militar americana

35 Documento 75. Ver trecho original em Transcrição 207, Transcrições (tradução nossa).

36 Documento 75: "BR 5602 set.1956 BRA media habits".

37 Documento 12: "Latin American Barometer, LA-6". 
em países do continente. Ela também mostrava uma rejeição menor aos comunistas, principalmente entre intelectuais e trabalhadores; além disso, reconhecia também acima da média latino-americana, que o comunismo favorecia os campos das artes, literatura, trabalho e educação. ${ }^{38}$

Em 1957, as pesquisas de opinião política nacional e internacional encomendadas pela USIA no Brasil apresentavam algumas novidades operacionais interessantes. Elas foram realizadas pelo Instituto de Pesquisas de Opinião e Mercado, que era localizado na Av. Franklin Roosevelt, 39, Rio de Janeiro, e se apresentava como "filiado à International Research Associates, Inc." ${ }^{39}$ Cada vez mais, a USIA criava instrumentos "aparentemente privados" para distanciar suas atividades de inteligência que alimentavam as decisões estratégicas da política externa americana.

As pesquisas de opinião política internacional de 1957, além disso, ampliavam seu escopo também para cidades médias e pequenas como São João do Meriti, Garanhuns, Campina Grande, Argolas, Franca e Guarulhos, entrevistando desde operários e donas de casa até altos executivos. ${ }^{40}$

A pauta da pesquisa também aumentava. Elas levantavam a opinião do brasileiro acerca da ação da OEA, do Presidente Eisenhower, do Presidente Nasser (Egito), do secretário de Estado Dulles, da crise israelo-palestina, da crise húngaro-soviética, do controle americano sobre o canal do Panamá, do uso pacífico da energia nuclear, do racismo nos EUA, da democracia, das ditaduras, do socialismo, do capitalismo, das possibilidades de uma nova guerra mundial e da presença cultural americana no Brasil. ${ }^{41}$

38 Documento 66: "LA-8, (Mexican and Brazilian atitudes toward Communism, Report \#8, July 2, 1956)”.

39 Documento 75: "BR 5603 fev 1957 (LA6) - (A study of Brazilian Public Opinion on selected national and international issues)".

40 Documento 75: "BR 5603 fev 1957 (LA6) - (A study of Brazilian Public Opinion on selected national and international issues)".

41 Idem. 
A complexidade e as relações entre preferências econômicas, políticas e de entretenimento também eram buscadas. Ao mesmo tempo em que as pesquisas descobriam que o Brasil era o país latino-americano que melhor reconhecia os ganhos com as políticas econômicas dos EUA, ${ }^{42}$ também eram medidas as preferências entre as audiências de TV nas maiores cidades brasileiras: se os paulistas gostavam mais do "Repórter Esso", patrocinado pela companhia de petróleo, ou do "O Céu é o Limite", patrocinado pela Varig, ${ }^{43}$ por exemplo.

Com o aumento da complexidade nas pesquisas no Brasil também era necessário um orçamento compatível. Em 1958, só para uma pesquisa contratada pela International Research Associates Inc./NY - que media a imagem americana e soviética nas cidades de São Paulo, Rio de Janeiro, Salvador, Belo Horizonte, Porto Alegre e Curitiba, entrevistando até 1.400 pessoas - a USIA despendia US\$20.000 dólares (18.200 de custo total e 1.800 como taxa de serviço da contratante). ${ }^{44}$

Além dos latino barômetros, a USIA produzia anualmente também os Fact Books de cada região do mundo, que compilavam todas as informações dos países pesquisados durante o ano. O Fact Book de 1959, por exemplo, cruzava dados diferentes sobre os países da região, formando um amplo painel de informações que acabavam se relacionando.

Os temas estudados abordavam estatísticas como a assiduidade de cada país latino-americano em votações conjuntas com os EUA na ONU, a lista de investimentos econômicos (ou empréstimos) americanos por país, números de empresas americanas, número de estudantes americanos em cada país, dados populacionais, estatísticas eleitorais, levantamento de atividades comunistas, perfil político (em relação aos EUA) dos jornais mais importantes de cada país, acordos para o uso de energia nuclear e o números de estações de rádio nos países. ${ }^{45}$

42 Documento 66: "LA-11 a LA-16, sendo: LA-11 (Latin American atitudes toward US economic policies, Report \#11, June 28, 1957)”.

43 Documento 75: "BR5802, abr 1958 - Television Viewing”.

44 Idem: "BR 5801, nov 1958 - Nationalism Study".

45 Documento 77. 
As extensas pesquisas da USIA sobre o Brasil, no geral, mostravam o sucesso de Eisenhower e uma aceitação dos EUA entre os brasileiros até o final dos anos 1950. Uma pesquisa qualitativa do final de 1959 mostrava que o brasileiro, em média, aceitava bem os EUA, com ressalvas somente aos conflitos raciais e à postura americana na América Latina: "Ao mesmo tempo em que eles têm muitas reservas sobre os EUA, particularmente em relação ao tema racial e à política americana para América Latina, não se pode afirmar que os brasileiros, na sua totalidade, são contra os EUA". ${ }^{46}$

A mesma pesquisa mostrava que o setor dos estudantes universitários discordava do resto da população no que diz respeito aos benefícios que os EUA traziam ao desenvolvimento do Brasil: "Enquanto a amostra dos estudantes universitários revelou uma tendência definitiva a acreditarem que as políticas econômicas dos EUA prejudicariam o Brasil, o público em geral, com algumas exceções, é muito mais favorável nas suas opiniões sobre esse assunto". ${ }^{47}$

Entre outros relatórios sobre temas específicos, o que se debruçava sobre estudantes no Brasil apontava para o comunismo presente em algumas universidades, como a Pontifícia Universidade Católica de São Paulo ${ }^{48}$ e a do Rio de Janeiro. Na PUC carioca, o USIS Rio chegou até a recomendar a instalação sobre uma biblioteca de referência, especializada no tema do trabalho, para "modernizar as relações arcaicas dos trabalhadores brasileiros":

A agência tem uma outra demanda por livros do campo do trabalho para a Universidade Católica do Rio de Janeiro, Brasil, que acaba de fundar um curso para líderes sindicais. [...] além da sua vantagem por ser um ato de boa vizinhança em círculos muito influentes, esta ação poderia ter um outro lado, de ser um meio para introduzir o tipo de relação mais sofisticada nas relações trabalho-administração que

46 Documento 78: "Brazilian Public opinion Surveys, Series 7, Report 4, December 22, 1959".

47 Documento 78: “Brazilian Public opinion Surveys, Series 7, Report 4, December 22, 1959".

48 Documento 76. 
prevaleceu nos EUA, em um país que somente agora está saindo de seu passado feudal e entrando em um futuro industrial ainda sem se resolver entre a iniciativa privada e o coletivismo. ${ }^{49}$

\section{UNCLASSIFIED}

$\mathrm{RO} / \mathrm{LA}-32-58$

Detober 29, 1958

\section{Catholic University of São Paulo}

\section{Pontificia Universidade Gatolica de Säo Paulo (Pontifical Catholic} University of São Paulo) Rua Monte Alegre 984, São Paulo, is one of six Catholic universities in Brazil. It is staffed by Benedictine priests. It was fully organized in 1946, although the Faculty of Law was organized in 1945. Besides the Faculty of Law, the univergity is composed of the Faculty of Philosophy, Sciences and Letters, the Faeulty of Economics, Accountancy and Actuarian Studies, the Faeulty of Industrial Engineering, the Faculty of Theology, and the Faculty of Medicine. It is approved by the Brazilian governnent which approval is equivalent to accreditation in Brazil. The school year is from Karch 1 to November 30, with vacation during the month of June. According to a 1957 publication, there were 489 faculty members and 2,955 students.

Affiliated organizations include the School of Journalisn, "Caspar Libero," the School of Social Service, the School of Trade and Adminietration, and the School of Nursing "Coroção de Maria."

Figura 33 - Relatório da USIA na América Latina resumia histórico entre possíveis focos de comunistas entre estudantes latino-americanos em 1958. Nesse caso, uma descrição da PUC-SP.

49 Documento 87, 19 de novembro de 1957. 
No último ano de JK no poder, os estudantes não eram a única voz dissonante antiamericana no Brasil. Um relatório de novembro de $1960^{50}$ que registrava as atividades "subversivas" comunistas na América Latina, descrevia uma marcha das Ligas Camponesas no Recife, em favor da campanha presidencial de Lott. O relatório notava que apesar da expectativa de Francisco Julião de reunir 5 mil pessoas, o Consulado americano no Recife tinha registrado somente mil. Entre os discursantes estavam Prestes e Brizola:

Com muita agitação anterior, mais de mil membros das Ligas Camponesas, carregando espadas de madeira e cartazes (incluindo fotos de Fidel Castro e Luiz Carlos Prestes), marcharam pelas ruas do Recife e participaram de uma manifestação em prol da candidatura de Lott, na manhã de domingo, 25 de setembro. Entre os oradores mais destacados do comício estavam o líder comunista Luiz Carlos Prestes e o governador do Rio Grande do Sul, Leonel Brizzola [sic]. ${ }^{51}$

No mesmo relatório interno, considerado secreto, o Ministro das Relações Exteriores do Brasil teria confidenciado que as manifestações de trabalhadores e greves do final de 1960 eram movimentos orquestrados externamente ao continente, de forma a minar os governos não só do Brasil, mas como do Chile, Argentina e Uruguai. Segundo a fonte brasileira, esse plano de "social subversion" era gestionado pela Embaixada Soviética em Montevidéu. ${ }^{52}$

O estudo ainda comentava os elogios feitos a Fidel, Cuba e suas políticas pelo então candidato a Presidente Jânio Quadros, em abril de 1960, e notava, sem muita preocupação, que a aproximação de Quadros com Cuba era usada politicamente para afastar as críticas de que o ligavam aos interesses de Wall Street. Segundo o informe, ao mesmo tempo em que era da UDN, tradicionalmente pró-americana, Jânio declarava não achar que Cuba era comunista.

50 Idem: "RO/LA 1960, 101-116 Complete, 1960".

51 Documento 76: "RO/LA 1960, 101-116 Complete, 1960".

52 Documento 76: "RO/LA 1960, 101-116 Complete, 1960". 
A vitória de Quadros, para os americanos, representava a primeira derrota de um candidato apoiado pelos comunistas nas eleições mais recentes (Lott) e que Jânio, teria tentado confundir a opinião pública para ganhar votos nacionalistas (antiamericanos). Mesmo visto como "imprevisível, igualmente um demagogo instável cujo objetivo principal é o poder pessoal”, ${ }^{53}$ para a USIA, Jânio apresentava um histórico pró-americano e havia tido uma vitória esmagadora:

é preciso reconhecer a força ultranacionalista de Quadros por tentar confundir sua posição e a de ultranacionalistas por meio de ações populistas como sua peregrinação a Cuba, seu cortejo com líderes neutralistas Afro-Asiáticos e seus comentários favoráveis sobre a educação de países comunistas. Apesar disso, Jânio Quadros foi identificado como amigo, e ao longo dos anos basicamente como pró-EUA; e ele venceu as eleições com uma lavada. ${ }^{54}$

Com a crise política interna causada pela rápida renúncia de Jânio, em agosto de 1961, e com as crises americanas em Cuba, as pesquisas de opinião política no Brasil a partir daquele ano ${ }^{55}$ intensificaram-se, focando principalmente populações rurais, trabalhadores, estudantes brasileiros e suas opiniões sobre personagens como Fidel Castro, Francisco Julião, Leonel Brizola, Jânio Quadros, João Goulart, mas também sobre o Presidente Kennedy e a Aliança para o Progresso.

Os resultados eram muito mais favoráveis à figura de Kennedy, com aprovação de 42\% em São Paulo e 53\% no Rio de Janeiro, com rejeição de $8 \%$ e $6 \%$ respectivamente nas mesmas cidades. A pesquisa $^{56}$ ainda mostrava que Castro era aprovado por $15 \%$ em São

53 Documento 74: “Inspection Report, USIS-Brazil, October 21, 1960”.

54 Documento 76: "RO/LA 1960, 81-100 Complete, 1960”.

55 Documento 79: "62-007, Brazil in Crisis, public opinion reaction in Rio and SP about the US - crisis Janio, 1961”.

56 Documento 79: "62-007, Brazil in Crisis, public opinion reaction in Rio and SP about the US - crisis Janio, 1961”. 
Paulo, 10\% no Rio de Janeiro e era reprovado respectivamente por $41 \%$ e $49 \%$.

As declarações de Kennedy em favor de uma solução brasileira para a crise causada pela renúncia de Jânio também era extremamente favorável nas principais capitais do sul do Brasil avaliadas, como Belo Horizonte, Porto Alegre, São Paulo e Rio de Janeiro, com mais de 75\% de aprovação dos brasileiros. A postura "afastada" de JFK era elogiada pela maioria dos brasileiros diante da crise da renúncia de seu Presidente recém-eleito. ${ }^{57}$

Naquele ano de 1961, as pesquisas da USIA também começaram a estudar mais de perto, também qualitativamente, o fenômeno das Ligas Camponesas no nordeste brasileiro. Essas avaliavam principalmente o potencial revolucionário de Francisco Julião, que segundo os relatórios americanos se aproximava cada vez mais do comunismo:

As chamadas Ligas Camponesas, organizações de camponeses com orientação comunista, existem há muitos anos. Sua maior liderança, Francisco Julião, viajou muitas vezes à "Cortina de Ferro", e suas simpatias pela reforma agrária como praticada em países comunistas - particularmente China - já foram expressadas publicamente. Julião antecede Castro como um líder revolucionário simpático ao comunismo... ${ }^{58}$

A importância que a USIA dava para entender o Brasil naquele momento de crise era tanta que Lloyd Free, o mesmo pesquisador que ajudou a pensar a reformulação da USIA no governo Kennedy, foi contratado (por meio do Institute for International Social Research, de Princeton) para melhor entender as mentes dos brasileiros em $1961 .{ }^{59}$

57 Idem: "BR 6102, Brazil in Crisis attitudes, Cuban-USA crisis opinion survey, sept. 1961".

58 Documento 80: "RO/LA 1961, 82-110 (Incomplete), 1961".

59 Documento 78: "Some International Implications of THE POLITICAL PSYCHOLOGY OF BRAZILIANS, by Lloyd A. Free, July, 1961”. 
O estudo, de mais de 70 páginas, analisava as propostas políticas de Jânio, as posturas do brasileiro médio em relações aos temas internacionais, bem como em relação aos EUA, China e Rússia. Além disso, analisava: o nacionalismo brasileiro, no legislativo e em geral; o poder e a influência de grupos rurais, urbanos, elites urbanas e forças armadas; a visão brasileira sobre o comunismo e sobre Fidel Castro; as aspirações populares, seus medos, preocupações, frustrações; e o tema da reforma agrária.

O estudo incluía 18 Estados brasileiros (dos então 21), baseando-se em 23 núcleos rurais e 19 urbanos e atingindo estatisticamente cerca de $91 \%$ da população brasileira. A pesquisa só excluía as populações do extremo Norte, na região amazônica. Ademais, também consultava fontes nas elites política e econômica do país.

Uma das hipóteses iniciais era que, apesar de minoritária, havia uma crescente insatisfação dos brasileiros em relação aos EUA desde a segunda metade da década de 1950, e que continuava crescendo até 1961, mas sem chegar a ser um sentimento de hostilidade. Ela se dava, principalmente por causa da maneira como os EUA se relacionavam com os outros países americanos, como Guatemala e Cuba, e com o crescimento de um sentimento de "independência" brasileira em relação aos EUA.

Entre os atores políticos, a maioria dos partidos apresentava opiniões satisfatórias em relação aos EUA, com exceção de um, o Partido Trabalhista Brasileiro (PTB), do então vice-Presidente João Goulart:

Somente os membros do P.T.B. (o Partido Trabalhista Brasileiro de base urbana, comandado pelo Vice-Presidente do Brasil, João Goulart) expressaram-se negativamente, acima da média, nessa questão; todos os outros partidos principais tiveram predominantemente a opinião de que as relações eram ao menos satisfatórias. ${ }^{60}$

60 Documento 78: "Some International Implications of THE POLITICAL PSYCHOLOGY OF BRAZILIANS, by Lloyd A. Free, July, 1961”. 
O estudo de Free abordava a questão do nacionalismo e da proposta de independência internacional que Jânio colocava como nova postura internacional do Brasil.

A conclusão do estudo era que o fenômeno do nacionalismo brasileiro era mais profundo e latente que o antiamericanismo ou o comunismo (que aparecia como minoritário). Considerando as diferenças sociais e regionais, o diagnóstico apresentava um país em expansão econômica e em busca de um maior reconhecimento internacional, o que não se conflitava, necessariamente, com os interesses anticomunistas americanos para a região.

$\mathrm{Na}$ conclusão do estudo, Lloyd Free expunha mais claramente essa visão:

se os americanos aprendessem a reconhecer e respeitar o verdadeiro significado do Brasil como o país mais importante da América Latina, com um potencial definitivo para exercer um papel de "grande potência” não só no hemisfério, mas também na cena mundial, não haveria razão para os EUA não viverem - confortavelmente, prazerosamente e com benefícios mútuos - com o nacionalismo brasileiro. ${ }^{61}$

A multiplicação das pesquisas da USIA no Brasil chamou a atenção de revistas brasileiras tidas pelos americanos como "comunistas”. Em levantamento periódico dessas publicações no Brasil, via-se como alvo de preocupação a reportagem da revista "Novos Rumos", da semana de 9 a 15 de novembro de 1962. ${ }^{62}$ Segundo o relatório americano, a revista teria como fonte um ex-pesquisador do instituto INESE. Em nenhum momento o relatório interno mencionou que as informações eram falsas, somente que as informações eram fundadas em "contractor indiscretions" (indiscrições do contratante).

61 Documento 78: "Some International Implications of THE POLITICAL PSYCHOLOGY OF BRAZILIANS, by Lloyd A. Free, July, 1961”.

62 Documento 80: "RO/LA, 101-126, 1962". 
A reportagem chamada "Violação degradante de nossa Soberania" descrevia o trabalho de três institutos brasileiros, que seriam usados como fachadas nacionais para pesquisas encomendadas pela embaixada americana no Brasil. Eram eles o INESE (Instituto de Estudos Sociais e Econômicos); o IPOM, ligado ao International Research Associates, que segundo a reportagem seria uma subsidiária do grupo Time-Life-Fortune e receberia cerca de 80\% da verba de pesquisa da Embaixada americana no Brasil; e a MARPLAN (Market Planning), que seria uma filial da agência de publicidade americana McCann Erickson. A notícia ainda denunciava outras empresas de pesquisa que seriam "fantasmas" da Embaixada americana, como a Promotion, que também prestaria serviços aos USIS.

A reportagem ainda citava que o INESE era sempre contratado por um senhor chamado "Marchetti", que seria chefe da área de pesquisa do Departamento de Estado americano, e que todas as informações coletadas sobre as opiniões políticas dos brasileiros, em suas diversas cidades e classes sociais, iriam para os arquivos do FBI americano.

Peter Marchetti é realmente uma figura recorrente entre os documentos de contratações de pesquisas da USIA na América Latina na década de 1960, mas sempre aparece como interlocutor de Don Wilson, com o cargo Project Officer. ${ }^{63}$ Apesar de algumas das pesquisas serem fontes de relatórios a outras agências americanas, em nenhum caso o FBI é citado entre os documentos oficiais consultados.

Apesar de os USIS serem citados na reportagem e de alguns nomes serem encontrados como institutos de pesquisa contratados com recorrência nos arquivos da USIA, como o INESE, a MARPLAN e o IPOM (além do IRA), a agência em nenhum momento era lembrada pela reportagem. Mais uma prova da eficácia do trabalho sigiloso da USIA. Os documentos e contratos que comprovavam a ligação entre esses institutos de pesquisa e a USIA só foram encontrados nos arquivos da agência, no National Archives and Records Administration de College Park/MA.

63 Documento 79. 
Coincidentemente ou não, a partir de 1963 a USIA amplia seu leque de colaboradores na área de pesquisa. Em relatório interno da agência de outubro de 1963, ${ }^{64}$ há uma lista de "research possibilities" oferecidas por outro instituto internacional, com sede em Bielefeld, Alemanha Ocidental, chamado EMNID (Institute for International Market and Public Opinion Research).

Entre as opções de institutos de pesquisa no mundo, o EMNID apresentava o Instituto Gallup do Brasil, com sede em São Paulo, que tinha como diretor o uruguaio Luis Ferreira, ex-funcionário da USIA no Brasil e no Uruguai. O mesmo documento destacava que o representante do EMNID na América Latina colaborava articuladamente com os institutos no Uruguai, no Brasil, Argentina e Chile. Pela ênfase na região, o trabalho de pesquisa articulado em toda América Latina deveria ser, segundo a USIA, modelo para as outras regiões do mundo. Segundo Oren Stephens, diretor do Departamento de pesquisa da agência na ocasião: "A América Latina está tornando-se a prova que demonstra o valor do nosso programa de pesquisa, que nós queremos ampliar a todas as regiões do mundo" ${ }^{65}$

No Brasil, as pesquisas continuaram também com os novos institutos, como o Gallup, aberto em São Paulo, em 1963, e no Rio de Janeiro, em 1964; ${ }^{66}$ e o Instituto Brasileiro de Opinião Publica e Estatística (IBOPE), que em 1963 começou a trabalhar com a USIA investigando a opinião dos brasileiros em relação à luta americana pelos direitos civis em Birmingham, e no progresso espacial. ${ }^{67}$ Além disso, a pesquisa cruzava as informações em relação aos EUA, como a imagem do Presidente Kennedy; e os principais líderes da esquerda brasileira - como Julião, Brizola e Jango - de acordo com classe social, cor, idade, região e ocupação.

A partir daquele ano, intensificaram-se as pesquisas com foco em regiões com maior potencial para a subversão "comunista" (na opinião da USIA), como o Nordeste brasileiro. Entre janeiro e

64 Documento 12.

65 Idem: "Latin American Barometer, LA-6".

66 Idem.

67 Documento 81. 
março de 1963, a agência contratou o Inese/São Paulo para medir o grau de contentamento dos beneficiados com os programas de apoio da "Aliança para o Progresso". O seu foco principal eram os agricultores nordestinos de cidades do sertão, agreste e litoral, como Cabo, Vitória de Sto. Antão, Pesqueira, Aurora, Cabrobó, Sapé, São João do Cariri e Caiçara. ${ }^{68}$

\section{DISTRIBUTION OF INTIRVIEIS}

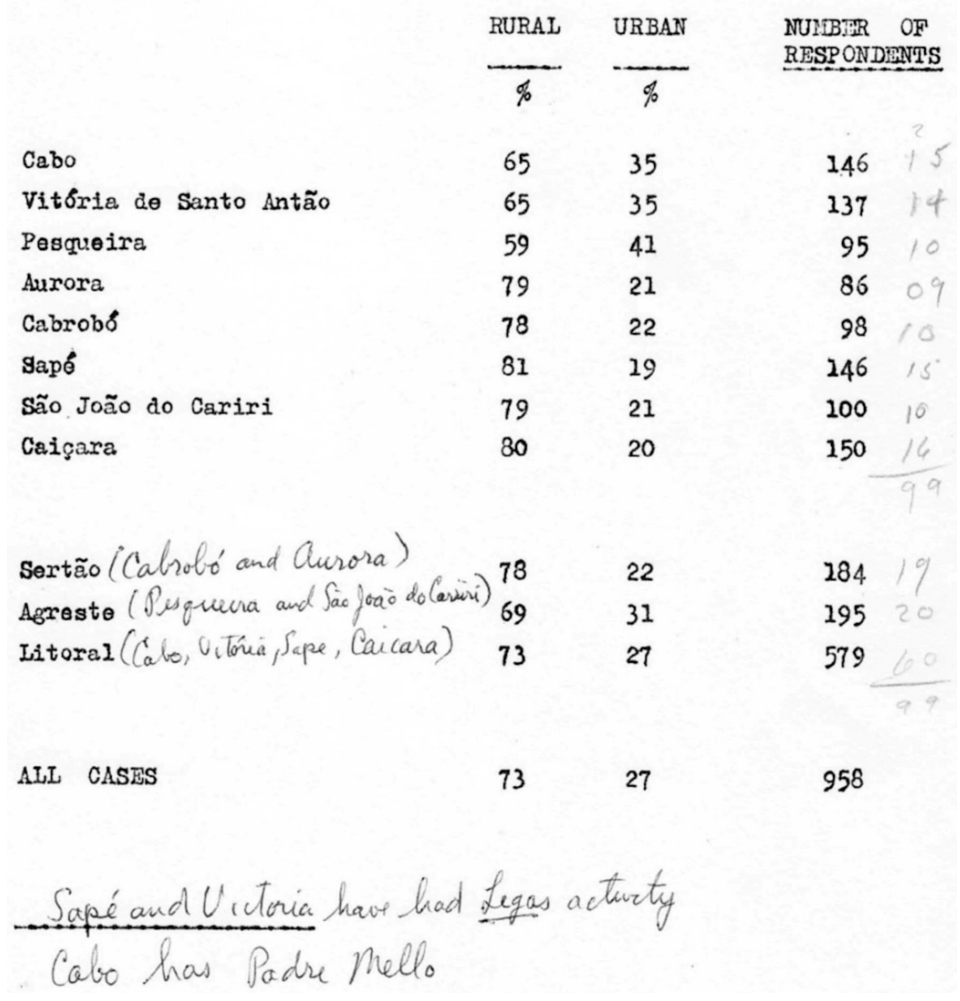

Figura 34 - Pesquisa do Inese, contratada pela USIA em cidades nordestinas beneficiadas pelos programa da Aliança para o Progresso, possíveis foco de subversão comunista.

68 Documento 82. 
A maioria das questões eram relacionadas ao perfil geral dos nordestinos beneficiados (origem, religião, nível social-econômico) e às opiniões dos agricultores em relação aos EUA, à Aliança para o Progresso, ao comunismo, a Julião, a Fidel Castro, a Arraes, a Jango, à SUDENE e às Ligas Camponesas. À caneta, algumas observações feitas mostravam as cidades que tinham tido atividades das "Ligas", como Sapé e Vitória; e outra com atividades de um religioso chamado "Padre Mello", como Cabo. ${ }^{69}$

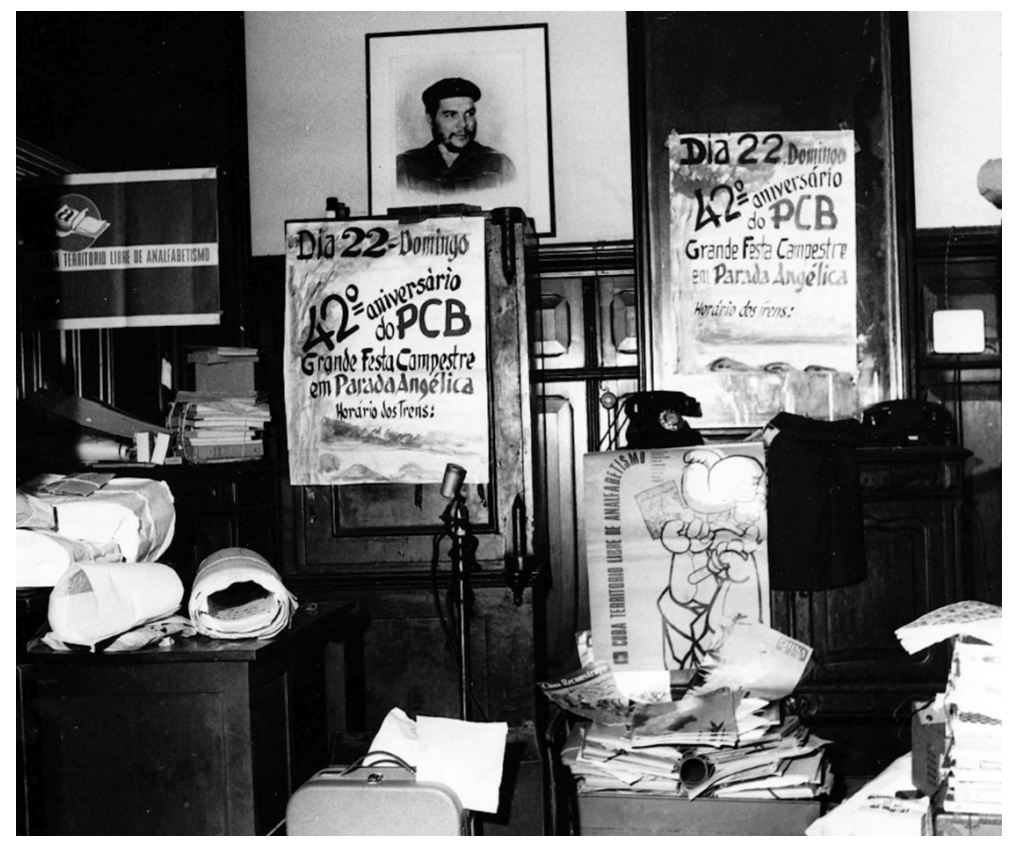

Figura 35 - Foto do USIS Rio, da sede da União Nacional dos Estudantes, em abril de 1964. Nesse dia foram apreendidos pôsteres do PCB e de temas comunistas.

Segundo Freitas (2005, p.5), o mencionado Padre Melo seria ligado ao IBAD (Instituto Brasileiro de Ação Democrática) ${ }^{70}$ e, como liderança em Cabo de Santo Agostinho (Pernambuco), dividia os

69 Idem.

70 Segundo Freitas (2005, p.5), o IBAD era financiado pela USAID. 
agricultores da região opondo-se às Ligas Camponesas e defendendo a criação de cooperativas ligadas ao Sindicato de Trabalhadores Rurais do Cabo.

Em 1963 e 1964, os estudantes se apresentaram como o foco de atenção das pesquisas da USIA para os grandes centros urbanos no Brasil. Mas, na maioria das pesquisas quantitativas, até 1964, os analistas da agência não conseguiam chegar a nenhuma conclusão inteligível: “...muitas das nossas evidências das pesquisas até agora nos levaram a uma reação "E aí?”, de uma grande parte do pessoal operacional da USIA." 71

Para melhor compreender os estudantes brasileiros, suas razões e formas de ação, a USIA contratou os serviços de Bryant Wedge, psicanalista social da Universidade de Princeton, por meio do Institute for the Study of National Behavior. Por um custo total de US\$ 20.598 dólares, ${ }^{72}$ a pesquisa de Wedge era chamada de "um estudo aprofundado das razões, atitudes e opiniões dos estudantes universitários no Brasil, relacionadas às questões públicas". ${ }^{73}$

Para isso, ele conversou com 800 estudantes e familiares, sendo que com 6 estudantes mais profundamente, e com 24 funcionários das faculdades. Wedge havia sido pesquisador bolsista durante o governo de Eisenhower, investigando especificamente estudantes em países estrangeiros. Nos EUA, ele também já tinha tido experiência anterior com um caso de universitários de Yale. ${ }^{74}$

O estudo apontava o papel fundamental dos estudantes no Brasil do imediato pós-Golpe, que segundo Wedge, eram o grupo que representavam a maior fonte de modernização, opinião e ação política no País. A pesquisa também apontava a dificuldade de interlocução dos EUA com a classe estudantil e as soluções para mudanças

71 Em relatório interno que justificava a necessidade de uma pesquisa mais aprofundada dos estudantes brasileiros, em fevereiro de 1964.

72 Documento 83: "BR 6403, Brazil Students Attitudes (Bryant Wedge Study), Oct. 1964-65”.

73 Idem.

74 Documento 83: "BR 6403, Brazil Students Attitudes (Bryant Wedge Study), Oct. 1964-65”. 
dessas relações, que só poderiam ser melhoradas a longo prazo, com políticas informacionais que fossem pré-testadas e pensadas profundamente. $^{75}$

Wedge via uma mudança do papel social dos estudantes universitários na década de 1960, assumindo um papel de classe reformista e popular, e não mais como uma aristocracia liberal, como nas décadas anteriores. Ao mesmo tempo, o pesquisador caracterizava a visão geral do estudante brasileiro como idealista e descolada da realidade social do país: "A situação do estudante pode ser caracterizada por uma independência considerável e isolamento de restrições sociais, conjugada com um alto idealismo e expectativa de ação, acompanhado por uma extraordinária falta de experiência prática" ${ }^{76}$

O estudo de psicanalista social de Princeton também se propunha a estudar a semântica dos estudantes brasileiros, tentando entender os variados significados de termos como democracia, socialismo, liberdade, revolução e suas diferentes aplicações em múltiplos contextos:

Eu estou tentando construir padrões da forma de conceptualização dos estudantes e como isso se expressa em comportamento. Mas isso é muito "escorregadio" e muito trabalhoso. Por exemplo, tanto Goulart quanto o governo "Revolucionário" reivindicam pelas palavras "democrático" e "revolução". Isto é frequente, mas torna as águas muito turvas. ${ }^{77}$

Além dos estudos de Wedge, os seus comentários informais (em outubro de 1964) ao contratante dessa pesquisa - John Evans, então funcionário da divisão de pesquisa da USIA (Research and Reference Service) - eram esclarecedores da sua visão. Escritas à mão em caneta esferográfica, em blocos de papel de hotéis cariocas (como o "Argentina Hotel”, na Rua Cruz Lima, 30, Flamengo; ou do

75 Idem.

76 Idem: "BR 6403, Brazil Students Attitudes (Bryant Wedge Study), Oct. 1964-65”.

77 Documento 83: "Bryant Wedge to John Evans, 5 February 1965". 
“Guanabara Palace Hotel”, na avenida Presidente Vargas, 392, no centro carioca), o pesquisador americano caracterizava o brasileiro médio e o turbulento momento em que o país vivia depois do golpe de $1^{\circ}$ de abril.
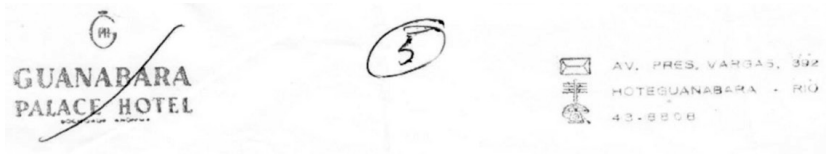

Pure Mary!

But no triumph if propagendait think this view wauld bave veen incented hese if max never strieled, it fits the bocal mind und aveicty mast presiely. Reguttably, aur hest effortar ame seloctively pereieved in tans of this formula and opten only feed the monster. seam to ham on sacellent counting tean, In expecielly inpressed with the Shivext leffoirs office of grontess. Thes molifies the urularse some but val much, So, in Che studest mingl. There is a amesome potontial for gevalution against us -thomen not necessaricy for our advarices of the C.P. This doesn't say anything obout why things are this way or what we mingt do about it, if ang thing seept to prepare to he tabront... whine unjith in
petty hand.

$$
\text { But there is a problem and its }
$$

a bitch.

Figura 36 - Carta do pesquisador americano sobre estudantes brasileiros: Brasileiro seriam marxistas mesmo se não existisse Marx. 
Entre os comentários mais interessantes, o pesquisador dizia que o brasileiro médio tinha a mentalidade marxista por natureza e que seria assim mesmo se não tivesse existido Marx: "Marx puro! Mas não por causa da propaganda: Eu acho que essa visão seria inventada aqui mesmo se Marx nunca tivesse existido, se encaixa na mentalidade local e na sociedade mais precisamente" ${ }^{78}$ Por isso, os EUA enfrentariam a vontade estudantil de fazer a revolução contra os americanos, que não era motivada necessariamente em prol do comunismo: "na cabeça do estudante, há um grande potencial para uma revolução contra nós - não necessariamente em favor de nossos adversários do P.C." ${ }^{79}$

O pesquisador percebia a instabilidade de opinião dos brasileiros e, por isso, mudava frequentemente de "personagem" para suas entrevistas, tendo respostas completamente distintas dependendo da maneira como era identificado. Às vezes Wedge se dizia marxista, e em outras era confundido com agente da CIA. Segundo ele, isso também se dava pela grande capacidade de espírito conspiratório dos brasileiros:

As opiniões expressadas dependem de com quem eles acham que estão falando - eu já fingi ser marxista, e é uma boa coisa não confessar para quem estou trabalhando, e de qualquer maneira eles acham, frequentemente, que sou o 007 ou CIA, já que há um grande amor pela conspiração - e obtive respostas completamente diferentes da mesma população. ${ }^{80}$

Para Wedge, o espírito modernizador dos estudantes do Brasil, que ainda apresentavam estruturas arcaicas e aspirações do século 21, sobreviveria mesmo com a "revolução" (que ele também chamava de golpe) de 31 de março, ou com a manutenção do poder dessas forças conservadoras:

78 Documento 83: "BR 6403, Brazil Students Attitudes (Bryant Wedge Study), Oct. 1964-65”.

79 Idem.

80 Idem. 
Cheio de paradoxo, caos, anarquia, desorganização, mito, estereótipo, etc. ad infinitum. Enterrados ainda em fortes estruturas e tradições (economicamente do meio do século 19, com feudalismo político, e aspirações do século 21) os estudantes, pelo menos, estão inclinados a viver em um futuro mítico. Em uma análise preliminar, parece-me que um justo ímpeto para uma revolução modernizadora foi soterrado por causa da "revolução" ou golpe de 31 de março, mas de nenhuma maneira está morto, mesmo se o poder e as estruturas de autoridade permaneceram com as forças conservadoras. ${ }^{81}$

Como conclusão, o pesquisador contratado pela USIA diagnosticava uma situação problemática para os EUA com relação aos estudantes brasileiros, e propunha uma postura de tolerância para com esses: "Isso não diz nada sobre porque as coisas estão dessa maneira ou o que nós podemos fazer, exceto que temos que nos preparar para sermos tolerantes, o que pode ser muito duro. Mas há um problema e ele é muito difícil". ${ }^{82}$

Algumas das pesquisas de cientistas sociais aplicadas à realidade latino-americana financiadas pelo Departamento de Estado, chamadas de "Projeto Camelot" foram denunciadas na imprensa americana e causaram pesadas críticas, dentro dos EUA, aos métodos do governo norte-americano na América Latina. ${ }^{83}$

À medida que o governo Johnson se dedicava mais ao front vietnamita, o uso da pesquisa sociológica foi perdendo força dentro do governo, como fator importante na tomada de decisões. ${ }^{84}$ Mesmo com menor interesse da Casa Branca, algumas pesquisas sociais

81 Idem.

82 Documento 83: "BR 6403, Brazil Students Attitudes (Bryant Wedge Study), Oct. 1964-65”. A carta também foi objeto de artigo meu no sítio eletrônico da revista Carta Capital, em novembro de 2014, Santomauro (2014).

83 Referência sobre o Projeto Camelot é o livro de Horowitz (1967): "The Rise and Fall of Project Camelot: Studies and Relationship between Social Science and Practical Politics".

84 Bogart (1995. p.xviii). 
continuaram a ser feitas nos países latino-americanos, porém sem a mesma profundidade dos desenvolvidos até $1964 .^{85}$

No Brasil, por exemplo, na época dos escândalos da Camelot, destacava-se o estudo feito pelo sociólogo José Arthur Rios ${ }^{86} \mathrm{em}$ 1965, que usava muitos estudos nacionais, como os de Fernando Henrique Cardoso: "A pesquisa foi dificultada e atrasada pela repercussão sobre o projeto Camelot, no entanto esse projeto em particular não foi seriamente atacado no Brasil por causa da importância do sociólogo envolvido" ${ }^{87}$ Por encomenda da USIA, o estudo analisava as possibilidades de criação de novas lideranças empresariais brasileiras, principalmente focando o empreendedorismo em São Paulo, em um texto chamado Paths to Leadership in Brazil.

No entanto, ao longo do governo Johnson, esse tipo de pesquisa foi se tornando cada vez mais rara. O Office of Research and Analysis foi perdendo importância e se afastando gradativamente da USIA: em 1966 ele se fundiu com o Office of Policy, formando o Office of Policy and Research, em uma tentativa de tornar a pesquisa mais "aplicável" às políticas da agência, seguindo as recomendações do U.S. Advisory Commission on Information, do Departamento de Estado. A mesma comissão indicou a separação completa do Departamento de Pesquisa da USIA, o que foi feito em 1969. ${ }^{88}$ Dos anos 1970 aos 1990, o Office of Research mudou de nome e funções, voltando e saindo da USIA (ou USICA), mas nunca deixando de existir definitivamente até o fim da agência, em 1999. ${ }^{89}$

85 Sobre pesquisas sociais no Paraguai em 1966, observa-se que mesmo após os escândalos do Projeto Camelot, pesquisas sociais no mesmo formato continuaram a ser feitas na América Latina, ver Bogart (op. cit).

86 Documento 85.

87 Idem.

88 Documento 69.

89 Documento 69. 


\subsection{A estrutura da USIA: Usis, Consulados e os Centros Binacionais Brasil-EUA}

Como visto, a USIA tinha toda a base do planejamento e da eficácia de suas ações na pesquisa de opinião pública e nas pré-pesquisas de programas a serem aplicados. Cada Country Plan era formatado de acordo com esse processo, alimentado pelas análises anteriores.

Para a boa aplicação das políticas era fundamental a adequada ramificação regional, o eficaz trabalho conjunto entre a USIA em Washington D.C. com os USIS e a apropriada realização do que foi pensado especificamente para cada local. Por isso, o bom funcionamento das representações da agência no exterior eram parte essencial do sucesso da USIA.

Os USIS no Brasil eram anteriores à formação da USIA e o País era um dos exemplos mais exitosos na quantidade e qualidade dos serviços de informação americanos desde a 1ª Guerra Mundial. Eles estavam presentes nas bibliotecas, centros culturais Brasil-Estados Unidos, postos móveis, Consulados e Embaixada.

Após a multiplicação de representações no País durante a $2^{\mathrm{a}}$ Guerra, com o Birô ${ }^{90}$, em 1950 os dois países assinaram um convênio de cooperação bilateral, que incentivava a criação de institutos, sociedades, centros e associações culturais para multiplicar as relações entre Brasil e EUA, abrindo possibilidades legais de ampliação das políticas culturais americanas no País (Haines, 1989, p.164). Só durante o ano de 1950, os frequentadores dos centros binacionais na América Latina cresceram de 16 mil, para 25 mil, em 1951. Metade desses era de estudantes universitários..$^{91}$

No começo dos anos 1950, as principais atividades dos centros binacionais eram relacionadas a programas de rádio, de músicas e exibição de filmes, com mais de um milhão de espectadores só no ano de 1950, na América Latina. Quase 70\% desses eram frequentadores

90 Mais sobre os "Cultural Institutes Project" do Birô, dedicado à criação dos centros binacionais em Documento 14.

91 Documento 36. 
de feiras e exibições. Naquele ano, eram 27 os centros binacionais na América Latina e 7 deles estavam no Brasil, em cidades como Curitiba, Fortaleza, Porto Alegre, Rio de Janeiro, Salvador, Santos e São Paulo. ${ }^{92}$

Em muitos dos centros, eram oferecidas aulas de danças, palestras, peças de teatro, recepções, exposições, comemorações, chás da tarde e eventos esportivos. A localização de cada posto era estratégica para atingir o tipo de público-alvo a ser mobilizado. O centro binacional em Copacabana, por exemplo, era voltado para a classe mais alta da então Capital Federal e aos turistas que passavam pelo bairro (Bogart, 1995, p.61).

A expansão de postos locais foi rápida a partir de então, e no ano de 1952 o Brasil já contava com postos também em Belém, Recife, Vitória e Belo Horizonte, com 129 funcionários, dos quais 29 americanos e 100 brasileiros, e um orçamento anual de US\$ 702 mil dólares. ${ }^{93}$

O crescimento orçamentário da USIA continuou a crescer e em 1954 o Brasil recebia investimentos de US\$ 1,745 milhão de dólares. ${ }^{94} \mathrm{Em} 1955$, postos locais, principalmente dedicados à produção de filmes, foram instalados em Florianópolis, Goiânia e Manaus, além de um novo centro binacional em Caxias do Sul..$^{95}$

Muitas vezes, ao invés de cargos que os ligassem à atividade de informação (Information Officer ou Public Affairs Officer), os funcionários de "informação" ocupavam postos diplomáticos, o que segundo relatórios internos dos USIS no Brasil fazia com que esses fossem aceitos mais facilmente:

não há nenhum sinal de descriminação evidente contra os funcionários dos USIS [...] Não há evidências de que postos diplomáticos

92 Documento 36.

93 Documento 33. O segundo país da América Latina era o México, com 113 funcionários, 3 postos e um orçamento de US\$ 650 mil para 1952.

94 Documento 88.

95 Documento 74: "Inspection Report of USIS Brazil, August 15-September 28, $1955^{\prime \prime}$. 
adicionais (ou outras graduações) do programa de informação são absolutamente necessárias. Por outro lado, a eficiência do programa seria aumentada se esses fossem nomeados em outros cargos, com títulos diplomáticos. ${ }^{96}$

Nos postos locais brasileiros, a proporção entre funcionários do Departamento de Estado e da USIA era aproximadamente igual, assim como a divisão dos custos (51\% cobertos pela embaixada e 49\% pela USIA). Em 1955, havia 65 funcionários do Departamento de Estado (48 americanos e 17 brasileiros), e 62 funcionários da USIA (15 americanos e 47 brasileiros) nos postos do Brasil. A curiosa diferença nos cargos da USIA devia-se à maioria de brasileiros, enquanto que nos do Departamento de Estado a maioria era americana. A distribuição de competências e de postos locais se apresentava da seguinte maneira:

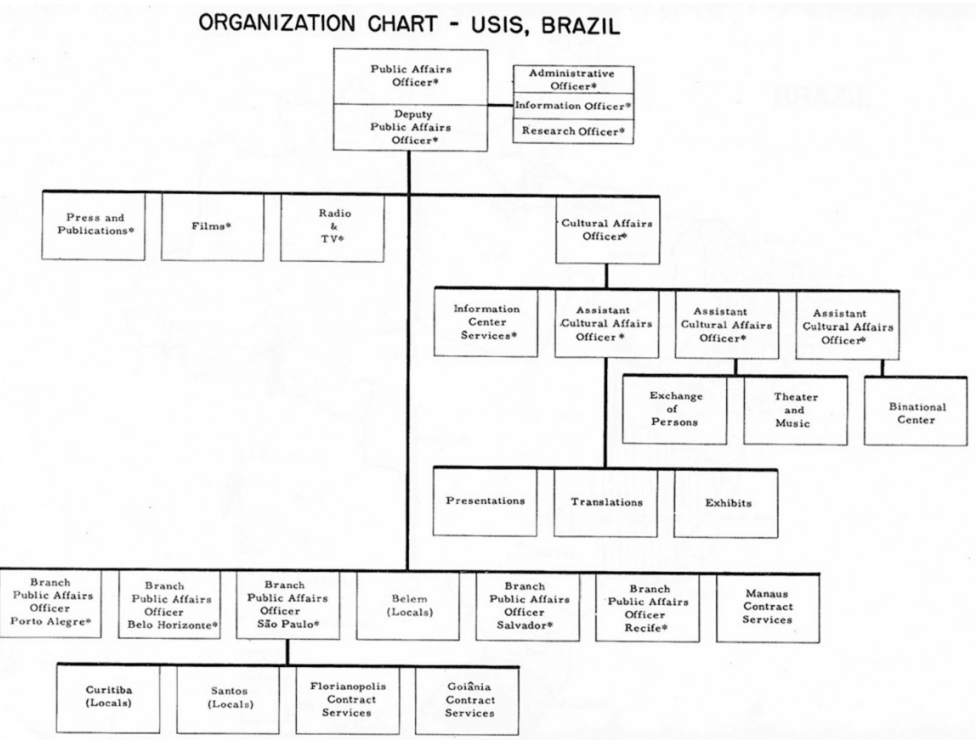

Figura 37 - Organograma de postos e funções dos USIS no Brasil, em 1955.

96 Idem. 
Para as direções locais ou para composição dos conselhos dos centros binacionais, os EUA buscavam cooptar lideranças brasileiras influentes, que acabaram sendo ministros de Estado ou Presidentes, abrindo caminho para a política local e atingindo grupos de interesse. Segundo Frank Oram, PAO no Rio de Janeiro:

Cada vez mais, nós notamos que ministros de governo são ex-Presidentes dessas organizações ou foram membros dos seus conselhos; em outras palavras, a experiência deles neste programa segue com eles quando assumem seus novos altos cargos no governo. Nós achamos que é uma forma extremamente versátil de atingir grupos especiais, assim como ensinar inglês para lideranças do trabalho, que em maio próximo virão aos EUA. ${ }^{97}$

A intenção da USIA era cobrir todo o País com os serviços de informação, apesar dos desafios para a comunicação interna, logística e orçamento impostos pela dimensão continental do país. ${ }^{98}$ Cada posto regional seria responsável por produzir e distribuir os materiais, contatar as lideranças locais, organizar turnês artísticas e esportivas, promover palestras, feiras e exposições, exibir filmes e ensinar inglês em sua "macrorregião": ${ }^{99}$

O sucesso de alguns dos centros binacionais no Brasil até virou exemplo, para a USIA, de postos que se autofinanciavam localmente. Em discurso sobre a eficácia dos centros binacionais em 1959, George Allen mencionava o caso do centro binacional do Rio de Janeiro, que patrocinou com fundos próprios a palestra do escritor americano John dos Passos e a conferência do governador de New Jersey, Robert B. Mayner, que ficou durante 6 dias na cidade, em 1958. ${ }^{100}$

97 Documento 89.

98 Documento 74.

99 Documento 74.

100 Documento 90. 


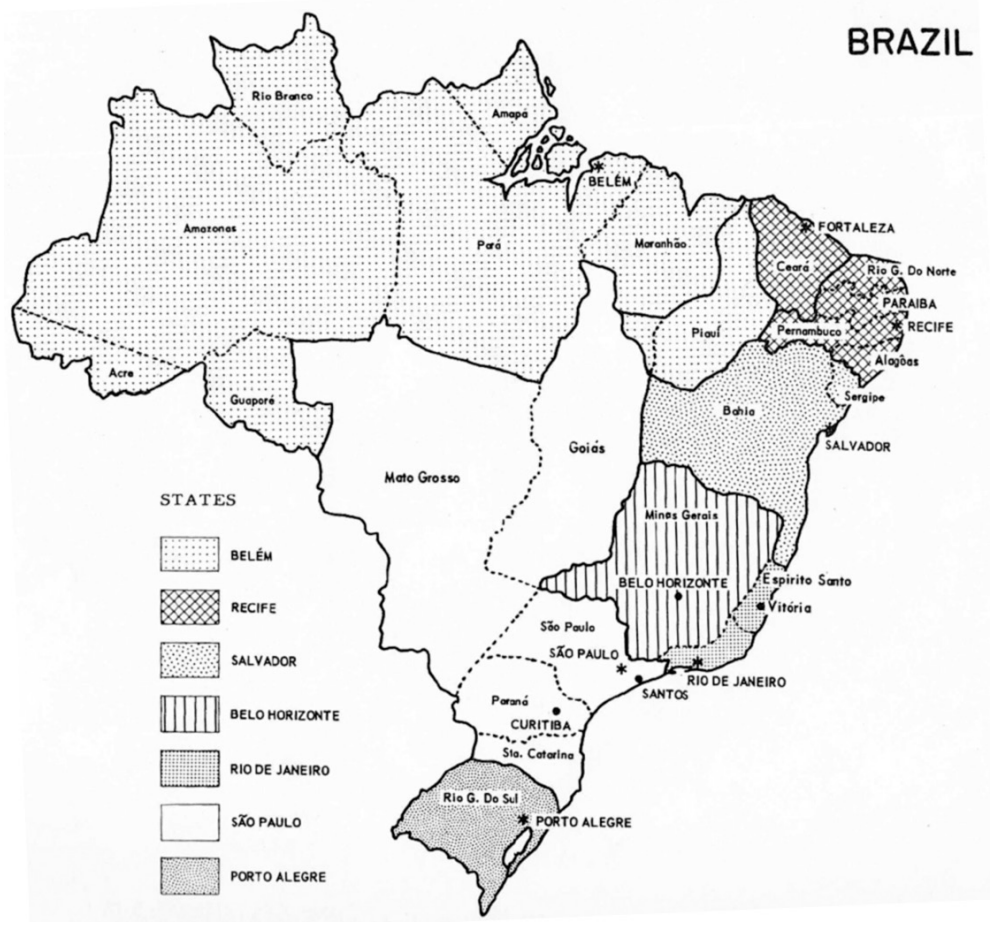

Figura 38 - Distribuição regional da abrangência dos USIS no Brasil em 1955.

Os centros binacionais no Brasil se multiplicaram exponencialmente durante o governo Eisenhower, solidificando a penetração da política da USIA no País. Em 1960, o Brasil contava com 57 centros binacionais, de tamanhos e importâncias variados, com 26 funcionários americanos, além de 22 bolsistas americanos e 128 funcionários brasileiros. ${ }^{101}$ Além disso, dois novos postos foram criados naquele ano, em Brasília e Curitiba.

Todo esse esforço do governo Eisenhower visava combater o principal problema das relações Brasil-EUA, que segundo a análise americana, era de "fundo psicológico". Mas um relatório da USIA de 1960, também alertava que as políticas de aproximação

101 Documento 74: "Inspection Report, USIS-Brazil, October 21, 1960”. 
"psicológica” dos USIS só alcançariam resultados positivos se acompanhadas de ações práticas de cooperação econômica e social:

Como os problemas principais nas relações brasileiro-americanas é eminentemente psicológico, não é verdadeiro achar que as soluções para eles são somente o campo psicológico e informacional-cultural dos USIS. A voz dos USIS é pequena se comparada com as numerosas influências americanas que agem entre os brasileiros e, por causa das realidades sociais e econômicas envolvidas, não se pode esperar que somente com palavras serão resolvidos os problemas brasileiro-americanos. ${ }^{102}$

Os novos postos no Brasil eram administrados pelos cinco comandos regionais operados a partir do Rio de Janeiro: São Paulo, Belo Horizonte, Porto Alegre, Recife e Salvador; e dois sub-comandos adicionais: Belém e Santos. ${ }^{103}$ Todos esses (além de sete outros postos subcontratados pela USIA) difundiam os filmes, notícias e programas de rádio produzidos e operados nacionalmente. Para isso, a USIA dedicou grande parte de seu orçamento em 1961: dos US $\$ 1,768$ milhão para os USIS no Brasil, US\$1 milhão era dedicado a gastos com a mídia. ${ }^{104}$

A USIA classificava os diferentes perfis de centros binacionais entre "A", aqueles financiados em maior grau pelo governo, com pelo menos um bolsista anual americano, com funcionários contratados pelos USIS e capacidade de produzir materiais próprios, como filmes, notícias e artistas; "B", os que recebiam menor apoio do governo, mas mantinham um funcionamento padrão, com aulas de inglês, bibliotecas, com materiais fornecidos pelo "A" mais próximo; e "C", menor número de atividades, com pelo menos um pequeno grupo de estudos de inglês, muitas vezes nascidos de iniciativas individuais, que pediam reconhecimento e apoio do Governo

102 Idem.

103 Documento 74: “Inspection Report, USIS-Brazil, October 21, 1960”.

104 Idem. 
americano. Em 1960, o Brasil tinha 16 centros considerados "A", 11 centros "B" e 32 do tipo "C". ${ }^{105}$

O posto de São Paulo coordenava as ações também no Estado do Paraná e distribuía materiais para Goiás, Mato Grosso e oeste de Minas Gerais. O foco temático de São Paulo era principalmente estudantes e trabalhadores. Entre as atribuições do USIS São Paulo estavam três grandes centros binacionais de tipo "A" (São Paulo, Santos e Sorocaba), além de oito de tipo "B" e onze de tipo "C", totalizando 22 centros sob sua "jurisdição". ${ }^{106}$

Um das ações destacadas do USIS São Paulo era o combate ao ultranacionalismo localizado na cidade de Campinas, que se opunha à iniciativa privada estrangeira no Brasil. Para se contrapor a esses movimentos, o USIS São Paulo produzia séries de artigos nos principais jornais da cidade para explicar a participação americana na economia local. Além disso, foram produzidos folhetos e um documentário especial sobre a participação americana no desenvolvimento de Campinas, financiado parcialmente pela representação local da Câmara Americana de Comércio. ${ }^{107}$ Segundo Dizard Jr. (2004, p.181), o USIS São Paulo, um dos exemplos de centros binacionais autossustentáveis nos anos 1960, tinha uma estrutura física grandiosa, com um prédio próprio de 17 andares, espaço para 600 alunos, biblioteca, auditório, restaurante e teatro.

O USIS Belo Horizonte, localizado no Consulado da cidade, coordenava dois centros binacionais "A" e oito de tipo "C", em 1960. O foco temático era principalmente voltado aos líderes sindicais, com a produção de uma série de materiais sobre o trabalho nos EUA e um programa de rádio local para os trabalhadores; e aos estudantes, com exibição de filmes apropriados para esse público, bolsas para o estudo de inglês e um esforço pessoal dos funcionários do USIS em desenvolver relações pessoais com intelectuais mineiros. ${ }^{108}$

105 Documento 74: “Inspection Report, USIS-Brazil, October 21, 1960".

106 Idem.

107 Idem.

108 Documento 74: "Inspection Report, USIS-Brazil, October 21, 1960”. 


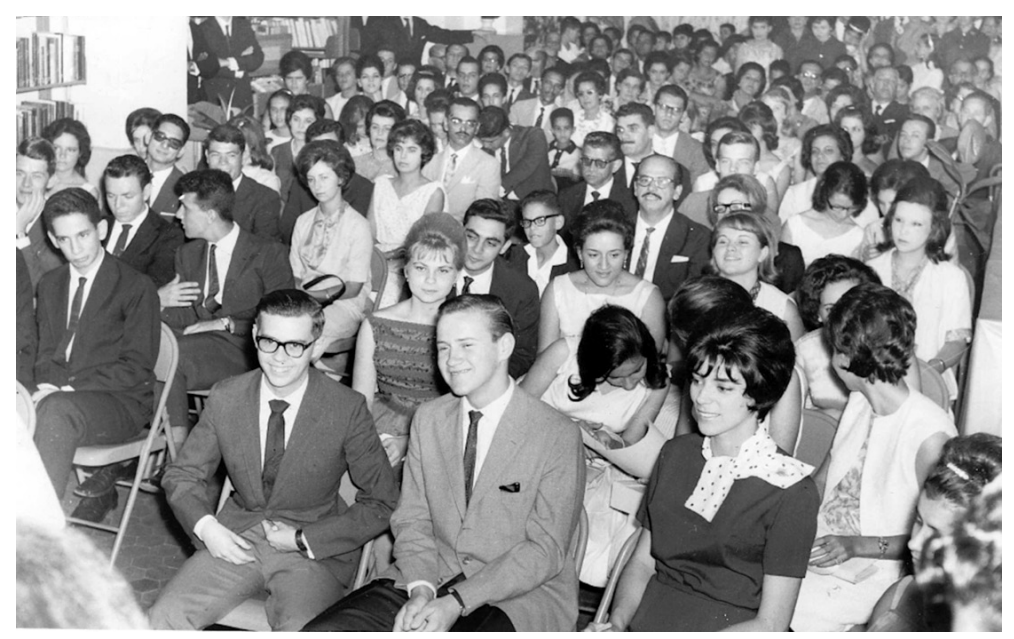

Figura 39 - Turma de formatura de cursos de inglês do centro binacional em Belo Horizonte, em 1962.

Em 1960, o USIS Porto Alegre era responsável por dois centros binacionais de nível "A", em Porto Alegre e Florianópolis; dois "B", em Caxias do Sul e Pelotas, e dois "C'”, em Bento Gonçalves e Lages. Outros centros menores e "embrionários", entretanto, pediam reconhecimento. Considerando a alta escolaridade da região e o histórico político (integralista e trabalhista), o foco nessa região era criar um "sentimento cívico", com aulas de educação cívica nas escolas locais, nos moldes do que a USIA fazia no México. ${ }^{109}$

No mesmo ano, o USIS Recife, responsável pelos Estados de Alagoas, Pernambuco, Paraíba, Rio Grande do Norte e Ceará, também considerava a baixa escolaridade e analfabetismo e por isso dedicava-se à exibição de filmes, rádio e TV. Além disso, administrava três centros tidos como "A", em Fortaleza, Natal e Recife; e quatro de tipo "C', em Crato, Sobral, Mossoró e Maceió. Ainda em 1960, o PAO local chamava a atenção para a necessidade de atingir o interior nordestino, possível foco de comunismo. ${ }^{110}$

109 Idem.

110 Documento 74: "Inspection Report, USIS-Brazil, October 21, 1960”. 
O USIS Salvador - responsável por dois centros binacionais "A", na própria cidade e outro exclusivo para a Universidade da Bahia, além de um "C", em Aracaju - era focado principalmente na rádio local e na produção de materiais gráficos para assuntos locais. ${ }^{111}$

O USIS Belém, "subposto” no Norte, tinha somente funcionários brasileiros e equipamentos considerados precários para cobrir a vasta área a que se propunha, como uma "station wagon ... in a completed dilapidated condition" (um furgão numa condição completamente precária). O serviço nesse posto dedicava-se a exibição de filmes, por meio de um projetor móvel que atingia as cidades mais distantes. ${ }^{112}$

O USIS Santos, outro "subposto" destacado pelo relatório interno da USIA em 1960, era um dos distritos consulares com uma das menores áreas em território em todo mundo, mas ainda assim com uma importância estratégica por causa do maior porto da América Latina e da crescente industrialização da região. Apesar de poucos funcionários, o posto santista contava com um funcionário destacado pela sua grande influência local: "um brasileiro muito respeitado, com ligações próximas a praticamente todos os contatos importantes em Santos, do prefeito aos editores de jornal, advogados e professores". 113

A estrutura interna de cada centro binacional e de cada USIS dependia de sua importância estratégica definida de acordo com o Country Plan e com suas competências e público a atingir. Frankel (1965, p.148) tentou tipificar uma estrutura básica de um USIS nos anos 1960, prevendo suas diferentes possibilidades de ação e atribuições:

111 Idem.

112 Idem. Mais sobre postos móveis que atingiam cidades mais distantes no interior do Brasil em Bogart, 1995, p.xiv, 51.

113 Documento 74. 


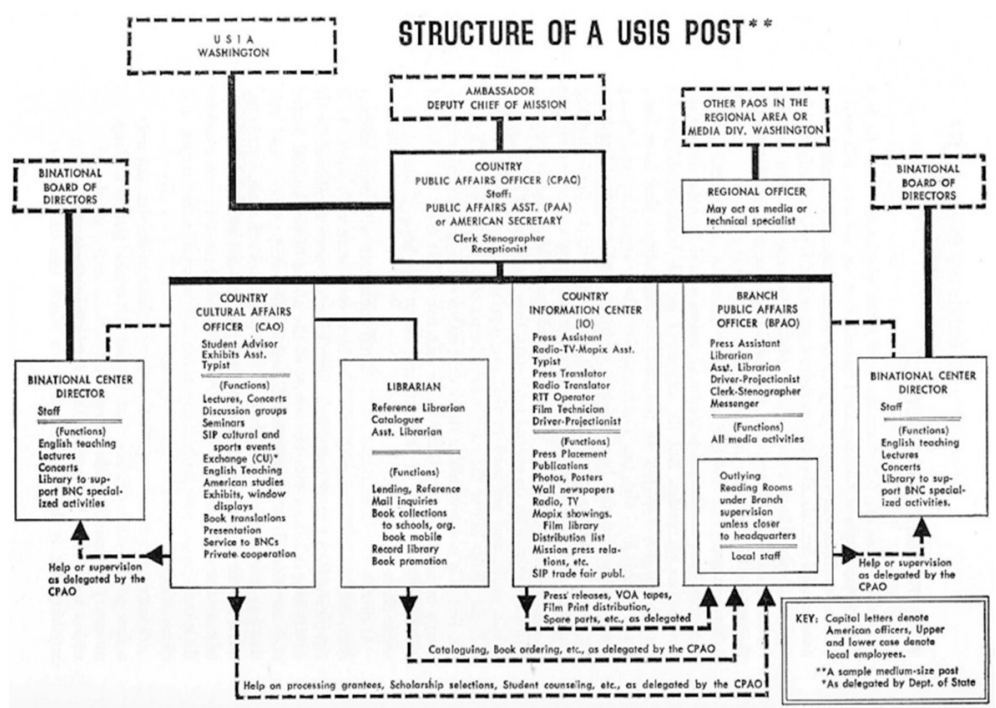

Figura 40 - Estrutura interna de um USIS nos anos 1960.

No começo dos anos 1960, os postos locais da USIA no Brasil continuaram a se proliferar. Em 1963, já eram 64 centros binacionais, institutos culturais e associações culturais Brasil-Estados Unidos, que distribuíam os materiais da USIA e irradiavam o pró-americanismo (e anticomunismo) País afora.

Eram eles: Araras, Araraquara, Barretos, Botucatu, Bragança Paulista, Itapetininga, Ribeirão Preto, Rio Claro, Jundiaí, Mirassol, Nova Granada, Piracicaba, Presidente Prudente, Santos, São José do Rio Preto, São Paulo, Sorocaba, Tatuí, Votuporanga (SP); Barbacena, Belo Horizonte, Aracaju, Bento Gonçalves, Governador Valadares, Juiz de Fora, Montes Claros, Teófilo Otoni, Ouro Preto, Uberaba, Uberlândia, Varginha (MG); Cachoeiro do Itapemirim, Campos, Lajes, Resende, Rio de Janeiro (RJ); Curitiba, Londrina, Maringá, Ponta Grossa (PR); Caxias do Sul, Pelotas, Porto Alegre (RS); Belém, Parnaíba (PA); Crato, Fortaleza (CE); Mossoró, Natal $(\mathrm{RN})$; Maceió (AL); Manaus (AM); Florianópolis (SC); Goiânia (GO); Recife (PE); São Luis (MA); Sobral (CE), Salvador (BA); Teresina (PI) Vitória (ES). Nesse mesmo ano ainda estavam em 
processo de formação centros em Araguari, Lavras (MG); e Passo Fundo, Rio Grande e Uruguaiana (RS). ${ }^{114}$

Após o governo de Johnson, como em outras áreas, a expansão da USIA, também nos seus postos locais na América Latina, arrefeceu. Em 1965, o Brasil ainda era o país do mundo com maior número de centros binacionais, mas já tinha diminuído para 39 no total. ${ }^{115}$ Ao longo da segunda metade da década de 1960, e nas décadas subsequentes, deu-se a tendência de diminuição do orçamento e do número de centros binacionais.

Segundo o Relatório Interno da USIA sobre os centros binacionais no Brasil:

Os gastos da agência com os centros binacionais mantiveram-se relativamente estáveis ou crescentes, atingindo seu pico no meio dos anos 1960, e a partir daí começaram a declinar [...]. O número de centros binacionais que recebiam financiamento da agência caíram de 39 em 1964, para 18 no ano de 1973 [...] da mesma maneira entre 1968 e 1973 o número de funcionários dos USIS ligados aos centros binacionais caíram de 25 para dois. ${ }^{116}$

Em 1973, por exemplo, o orçamento do governo americano para os centros binacionais no Brasil foi de US\$ 173 mil dólares, para os 18 centros restantes. ${ }^{117}$ Porém, ao mesmo tempo em que diminuiu o financiamento governamental para os centros binacionais no Brasil, houve um crescimento vertiginoso dos lucros dos centros binacionais que restaram no País, entre os anos 1950 e os anos $1970 .{ }^{118}$

Subsidiados em grande parte dos casos, nos anos 1940 e 1950, nos anos 1960 metade dos orçamentos dos centros binacionais no Brasil provinham dos fundos locais, principalmente com aulas de

114 Documento13: Lista de USIS do Brasil, com endereços e responsáveis em 1963.

115 Documento 11.

116 Documento 92.

117 Documento 91.

118 Documento 92. 
inglês. Nos anos 1970, somente 3\% do orçamento dos centros binacionais do Brasil vinham dos EUA. ${ }^{119}$

Mesmo com a diminuição do número de centros, o aumento dos lucros fez com que os centros binacionais que resistiram até os anos 1970 se mantivessem por si só, sem apoio governamental. O relatório interno da USIA em 1973 mostrava que "a receita total dos centros binacionais brasileiros até 1973 cresceram quatro vezes em relação à de 1964". ${ }^{120}$

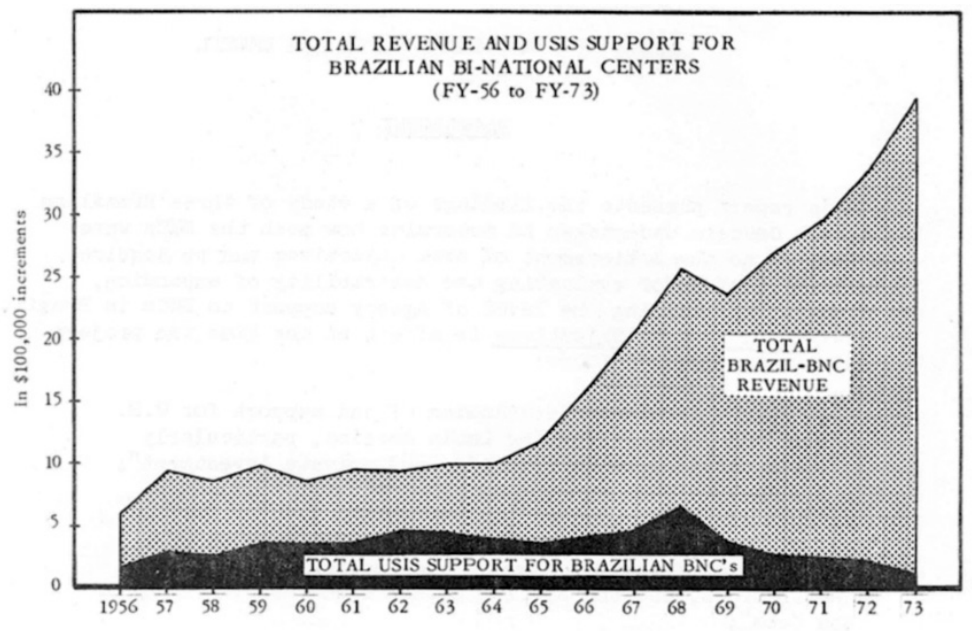

Figura 41 - Orçamento e apoio dos USIS nos centros binacionais do Brasil de 1956 a 1973.

O mesmo relatório mostrava que o objetivo buscado pelos USIS no Brasil nos anos 1950 e 1960 ainda fazia efeito nos anos 1970, quando a USIA já não via os centros binacionais como principal canal da política americana de informação. Ainda que sem a participação significativa de funcionários da USIA, nem uma política de informação que incluísse os centros, eles ainda eram vistos pelos brasileiros como lugares de excelência de cultura americana.

119 Documento 92.

120 Documento 92. 
Na mesma pesquisa de 1973, feita nas cidades que ainda tinham centros binacionais americanos, eles apareciam como mais importantes culturalmente (com 43\%) do que os franceses (4\%), alemães (11\%) e ingleses (5\%) para os seus moradores. Entre os pesquisados, a cultura americana em geral também aparecia como mais influente: $79 \%$ apontavam os americanos como os melhores em música popular; para $48 \%$, os melhores em literatura contemporânea; e para $35 \%$ os melhores em "estilo de vida" (contra 30\% da França).

Mesmo com a perda de importância na estratégia interna do governo, ao final de três décadas, dos anos 1950 aos 1970, os centros binacionais mostraram os resultados esperados inicialmente pela USIA, isto é, marcaram os EUA como referência cultural e de estilo de vida entre os brasileiros. Interessante notar também que os centros binacionais eram identificados pela população brasileira em geral como a forma de ação que era declaradamente do governo americano, ou apoiado por ele. Os outros meios de ação da USIA utilizaram-se, muitas vezes, de formas "não-assinadas" pelo governo, com objetivo de alcançarem ainda maior eficácia e penetração nos modos de vida e de pensar do brasileiro.

\section{A agência de notícias e a mídia impressa}

Com uma ampla penetração física no território brasileiro e o controle periódico dos humores e opiniões políticas, inclusive internacionais, dos cidadãos em geral e grupos-alvo em particular, a USIA também pretendia "moldar" a opinião pública nacional trabalhando para dialogar e influenciar, de toda maneira, os principais meios de comunicação do país. ${ }^{121}$

A forma prioritária de atingir a mídia em geral eram os jornais, revistas e principais publicações de maior circulação. Para isso, a USIA mapeava e mobilizava editores e jornalistas, produzia notícias

121 Sobre importância de "moldar" opinião pública brasileira para a USIA, ver Bogart (1995, p.54); Haines (1989, p.168). 
locais em seus centros, transmitia notícias e fotos e as disponibilizava por meio de sua agência de notícias. A agência ainda escrevia artigos apócrifos ou com nomes fictícios, pois sem mostrar a sua origem tinha maior credibilidade junto ao público nacional. Além disso, ganhava a adesão gratuita e voluntária de jornais importantes tidos como "pró-americanos".

A preocupação em oferecer notícias com a perspectiva americana em jornais brasileiros, que vinha desde o CPI de Creel, quando foram trazidas as primeiras agências de notícias americanas para a América Latina, continuou com o Birô de Rockefeller e no pós-guerra, com Truman. Na Guerra da Coreia, por exemplo, já havia um grande empenho midiático dos EUA para publicar notícias favoráveis ao esforço americano em jornais brasileiros. Fotos, artigos e quadrinhos pró-EUA eram difundidos pelos USIS no Brasil, além de suplementos como o Death comes from the Kremlim e One who survived (Haines, 1989, p.169). Quadrinhos como o Free World Speaks, abaixo reproduzido, eram confeccionados pelo governo Truman e enviados a todos os USIS do mundo:

Durante o governo Truman, a partir de fevereiro de 1952, os USIS no Brasil também produziram a revista "Em Marcha", inspirada na bem sucedida "Em Guarda" do Birô. Essa, contudo, era voltada a um público mais restrito, de classe média intelectualizada formadora de opinião, com uma linguagem mais sofisticada, diferente da mais "sensacionalista", divulgada pelos USIS nos jornais brasileiros. O trabalho do chefe da seção de imprensa do USIS Rio de Janeiro, Roberto Gonzaga, foi fundamental para a publicação de artigos alinhados com a opinião americana nos principais jornais brasileiros, como O Globo, Jornal do Brasil e Última Hora (Haines. 1989, p.169, 170).

Roberto Gonzaga tinha uma relação muito próxima com Assis Chateaubriand, o que também rendeu uma aproximação comercial entre a USIA e os Diários Associados, com quem a agência firmou um contrato para exibição de seus programas de rádio (como será visto no subcapítulo 3.6). Gonzaga também se relacionava com escritores influentes, como Lúcio Rangel, participando do processo 

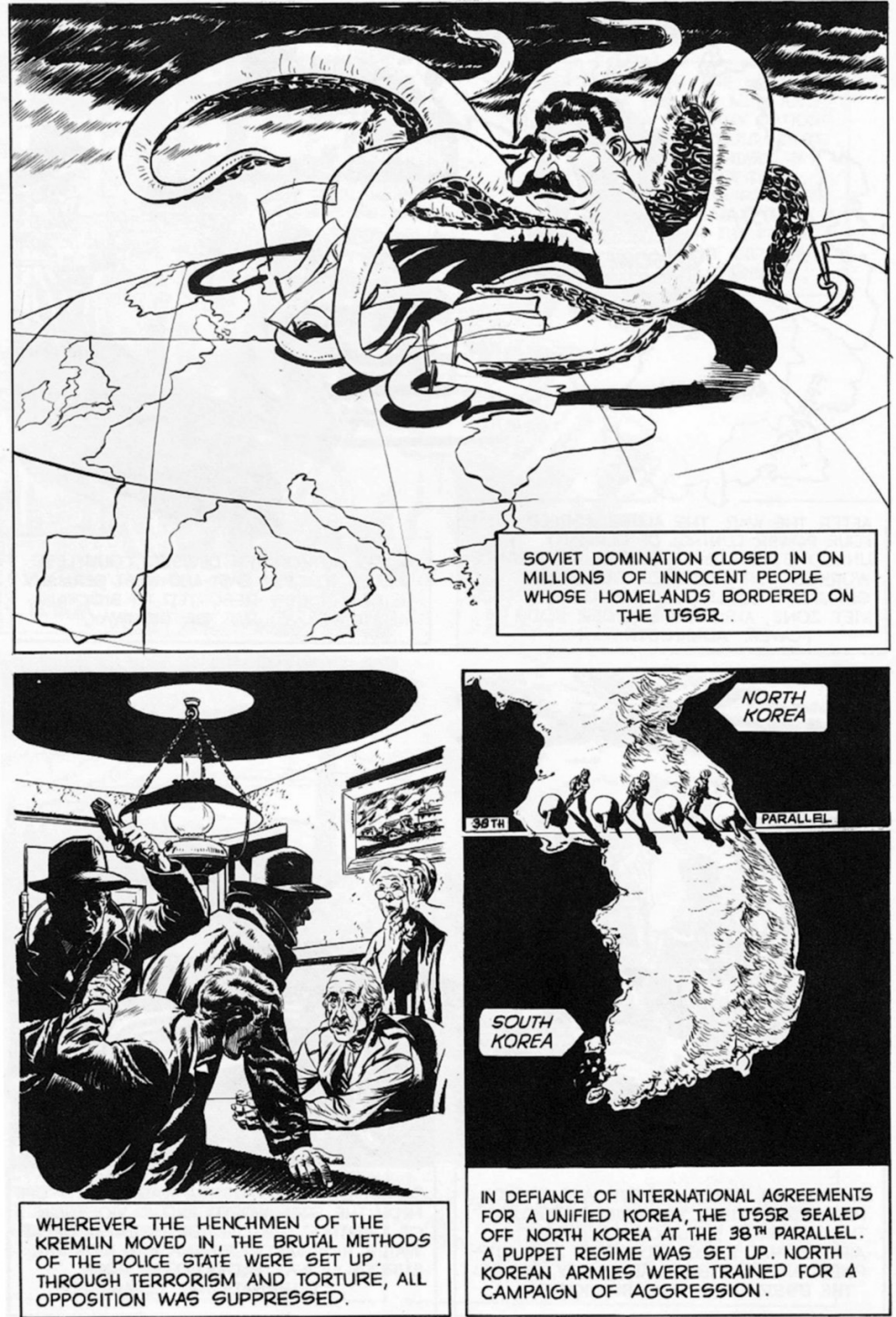

Figura 42 - Quadrinhos, como o Free World Speaks (1951) eram distribuídos durante o governo Truman nos USIS de todo o mundo, explicando a entrada dos EUA na Guerra da Coreia. 
de publicações de livros com apoio da USIA (o que será retomado no subcapítulo 3.4).

No ano de criação da USIA, 1953, o Country Plan para o Brasil detectava como um dos riscos políticos no País, o "Peronismo aliado com comunismo gerando o ódio aos EUA". ${ }^{122}$ Além disso, definia os públicos-alvo prioritários durante o governo Eisenhower: militares, funcionários públicos, responsáveis pelos grandes grupos de mídia, trabalhadores urbanos, rurais, formadores de opinião, artistas, empresários (principalmente industriais) e líderes de partidos políticos. ${ }^{123}$

Os desafios na mídia brasileira eram muitos. Com mais de 700 revistas de todos os tipos e com diferentes níveis de influência, mais de 1.300 jornais (sendo que mais de 100 eram diários e 26 deles só no Rio de Janeiro), era quase impossível a tarefa de cobrir os múltiplos pequenos grupos, pela grande variedade dos públicos consumidores dos periódicos. ${ }^{124}$

A precariedade logística de transporte e das comunicações em um país continental dividido por rios, montanhas e selvas, também dificultava a missão, segundo a avaliação interna da recém-formada USIA. Por fim, a grande taxa de analfabetos, de quase 60\% da população brasileira, segundo o Country Plan de 1953, também dificultava o acesso às notícias americanas. ${ }^{125}$

Naquele ano, um detalhado estudo sobre a eficácia da cobertura do Wireless Bulletin era feito nos 25 maiores jornais das principais cidades, que recebiam diariamente releases dos USIS em português e inglês para preparar a estratégia da agência a partir daí. Isso era feito primeiro com um receptor e distribuidor no Rio de Janeiro, e a partir de 1954 as notícias também começaram a ser distribuídas por São Paulo: "O BPAO (Branch Public Affairs Officer) em São Paulo está planejando fazer o monitoramento direto dos documentos que

122 Documento 94.

123 Documento 94.

124 Idem.

125 Idem. 
chegam pelo sistema sem fio (wireless file), utilizando-se de dois Hallicrafters ${ }^{126}$ adquiridos para esse propósito". ${ }^{127}$

A USIA também preparava legalmente a exportação de suas publicações (revistas, livros e até filmes) para o Brasil por meio do Informational Media Guaranty Program (IMG), que facilitava a exportação dos materiais americanos para países que não podiam pagar em dólar (como o Brasil). Com isso, o governo americano aceitava a moeda local e era o "fiador" para comercialização dos materiais de informação, fazendo o pagamento diretamente aos exportadores americanos. O acordo com o governo brasileiro para o envio de materiais americanos foi assinado em novembro de 1954. ${ }^{128}$

Preocupado com as publicações que, segundo relatórios de pesquisa internos, eram "comunistas", como os jornais "Democracia Popular", "Notícias de Hoje", "Imprensa Popular" e revistas como a mensal "Problemas", que seriam publicações do Partido Comunista do Brasil, ${ }^{129}$ a USIA começou a organizar um acompanhamento mais sistemático da mídia brasileira em 1955.

Os já comentados Barômetros, que começaram na América Latina e se estenderam para o mundo, eram compilados nos USIS e depois enviados para todas as agências e Departamentos relacionados ao sistema de inteligência, colocando a opinião pública como fator complementar entre as informações estratégicas no governo americano: "Esse material de inteligência, semiacabado, é um elemento do quadro de inteligência - a opinião pública - a ser considerado e interpretado sob a luz de outros elementos que chegarem às decisões políticas e programáticas". ${ }^{130}$

O controle sobre a mídia brasileira era, portanto, seguido de perto pela inteligência do governo, por meio de seu Social Science Research Group (formado em 1955), que continha os Departamento de

126 Aparelho de recepção de sinais, que poderia também retransmiti-los. Disponível em <http://www.hallicraftercollector.com>. Acesso em: 22 nov. 2013.

127 Documento 74.

128 Documento 94.

129 Documento 95.

130 Documento 93. 
Estado, Defesa, o OCB (Operations Coordinating Board), a CIA e a USIA. O chefe de pesquisa da USIA, que comandava esse grupo, Dr. Leo Crespi, também era o Presidente da World Association for Public Opinion Research.

Como já descrito, por causa das repercussões das parcerias entre Esso e as pesquisas americanas no Brasil, tanto na imprensa brasileira tida como comunista, quanto no NY Times, a companhia de petróleo e a Embaixada americana tomaram o cuidado de não mencionar a fonte de financiamento para as pesquisas de barômetro no Brasil em correspondências internas, mas a Esso continuava financiando o levantamento da mídia nacional em 1956. ${ }^{131}$

Segundo as recomendações da Embaixada, a empresa não deveria mais ser mencionada, nem em relatórios confidenciais internos:

Tanto a embaixada como a Esso acham que essa comunicação entre os dois sobre a informação deve ser tratada com o máximo de discrição... mesmo sendo classificado como CONFIDENCIAL, o Deputy Chief of Mission pediu para que os relatórios futuros desse tipo de apoiador não sejam identificáveis. ${ }^{132}$

As pesquisas americanas apontavam que, no geral, os editoriais dos maiores jornais brasileiros eram favoráveis aos EUA, durante os governos Eisenhower, Kennedy e Johnson. Segundo a USIA, o mais alinhado com a opinião americana era "O Jornal", de Chateaubriand:

O Jornal, uma parte dos Diários Associados, propriedade do abastado Senador Assis Chateaubriand, é o jornal mais amigável e o mais compreensível com os EUA [...] O Jornal também refuta os argumentos daqueles que apontam que os EUA abandonam o Brasil economicamente [...] O Jornal foi o que mais valorizou os frutos da colaboração com o capital estrangeiro. ${ }^{133}$

131 Documento 75.

132 Idem.

133 Documento 97. 
Entre os jornais de São Paulo, eram recorrentes as menções da USIA ao tom conservador e pró-EUA de "O Estado de S. Paulo" durante todo o período estudado (anos 1950 até anos 1980). Em fevereiro de 1956, por exemplo, O Estado de S. Paulo era destacado em relatórios sobre a mídia latino-americana feitos pela USIA, como o único jornal latino-americano a mencionar positivamente a oferta de urânio feita por Eisenhower, no âmbito do programa Atoms for Peace: "Somente um jornal, o influente O Estado de S. Paulo, do Brasil, dedicou um editorial ao assunto. $\mathrm{O}$ articulista de $O$ Estado elogiou a decisão de Eisenhower e diferenciou essa oferta generosa de parte dos EUA, em relação ao comportamento da União Soviética". ${ }^{134}$

Diferentemente do tom de parceria que a USIA adotava aos empreendimentos de Chateaubriand, no caso de "O Estado" os relatórios sempre apontavam que a linha editorial do jornal era naturalmente favorável aos EUA. E como demonstram relatórios da agência, era o próprio jornal que buscava o diálogo para publicação dos produtos da agência.

Esse era o caso do relatório da USIA, que resumia as cartas de leitores que chegavam à revista "Combate", segundo a agência, uma publicação que era distribuída em toda América Latina e bem aceita na maioria dos países. Segundo as cartas de leitores latino-americanos que chegavam à USIA, a maioria elogiava a revista por ser uma "porta-voz da democracia e da solidariedade continental". ${ }^{135}$

Entre as correspondências destacadas, em dezembro de 1958, estava uma carta do secretário da seção internacional de "O Estado de S.Paulo”, Oliveiros S. Ferreira, ${ }^{136}$ que pedia permissão para publicar os textos de "Combate" em seu jornal:

Eu considero como de inestimável valor para a discussão dos problemas da América Latina e para a formação de uma consciência política democrática na América Latina. [...] Como secretário da

134 Documento 96.

135 Documento 76.

136 Também professor de Ciência Política na Universidade de São Paulo, na PUC-SP e no Programa San Tiago Dantas. 
seção internacional no jornal O Estado de São Paulo [sic], e considerando que muito dos artigos publicados na revista Combate podem ser reproduzidos no jornal, eu gostaria de pedir o favor de saber sobre a possibilidade de transcrever esses artigos que parecerem apropriados. ${ }^{137}$

Para a USIA, O Estado de S. Paulo aparecia como crítico aos EUA somente quando reclamava uma maior presença econômica e política no Brasil:

O Estado de São Paulo, de visão conservadora, crítico mas basicamente um jornal amigável, dedicou atenção especial para a política dos EUA que afetaria a América Latina em geral e o Brasil em particular ...o jornal comentou sobre a "tristeza que a América Latina sente por ter sido abandonada ou traída pela política externa dos EUA desde a Guerra”. ${ }^{138}$

O jornal se desapontava com a falta de um maior compromisso por parte do Presidente Eisenhower durante a Conferência do $\mathrm{Pa}$ namá em 1956:

Considerou as palavras do Presidente Eisenhower com "um amargo desapontamento" de todos aqueles que esperavam que ele fosse demonstrar, nessa ocasião, que os EUA iriam responder aos "urgentes apelos daqueles que julgavam que o programa de ajuda americano não se orienta em direção aos que são os amigos mais leais da América". ${ }^{139}$

Mas apesar da postura crítica por reivindicar maior compromisso dos EUA para com o Brasil, "O Estado", assim como "O Jornal", e O Globo, eram jornais tidos como "responsáveis", com quem a

137 Documento 76.

138 Documento 97: "Brazilian Opinion of US Policies (June 1956)".

139 Documento 72: "IM- 23- 56, Latin American reactions to the Panama Meeting of Presidents of the American Republics, August 15, 1956". 
USIA contava para publicação de sua opinião no Brasil. Segundo relatórios da agência de 1956, tanto em "O Jornal", quanto em "O Estado" (assim como em outros jornais "responsáveis" do Brasil), ${ }^{140}$ foram publicados vários editoriais em favor do programa Atoms for Peace e contra o monopólio estatal brasileiro da energia atômica no Brasil. A USIA destacava a série de artigos especiais, publicados em maio de 1956 em O Estado de S. Paulo:

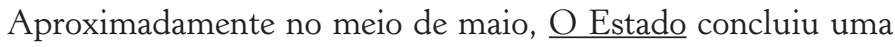
série de artigos especiais sobre o "Brasil na era atômica", produzidos para influenciar a opinião pública em direção à uma compreensão mais sadia sobre os problemas envolvidos. A série começou afirmando que, infelizmente, as paixões distorceram as discussões sobre esse assunto importante e que, em primeiro lugar, o que deveria ser decidido era se o monopólio do governo para o desenvolvimento da energia atômica era contra os interesses nacionais. Os artigos subsequentes discutiram o delicado tema da exploração das areias monazíticas e a exportação de óxido de tório para os EUA. A série concluía com a opinião de que "adotar uma política de monopólio do Estado em um campo que necessita de cooperação de empresas privadas, arriscava atrasar a utilização da energia atômica para fins pacíficos no país" O jornal dizia que enquanto o Estado tinha o absoluto direito de exercer a direção sobre o tema, essa seria melhor exercida por meio de uma autarquia. ${ }^{141}$

No mesmo ano de 1956, a USIA começava a usar, de acordo com diretrizes globais, temas de interesse da agência em séries de artigos especiais nos jornais brasileiros, seja sobre os benefícios do uso pacífico da energia atômica, como propunha o "Atoms for Peace" de Eisenhower em $O$ Estado de S. Paulo, quanto as séries de reportagens que alertavam sobre os riscos do comunismo, chamada de "A morte vem de Moscou", em O Globo.

140 Documento 97.

141 Documento 97. 

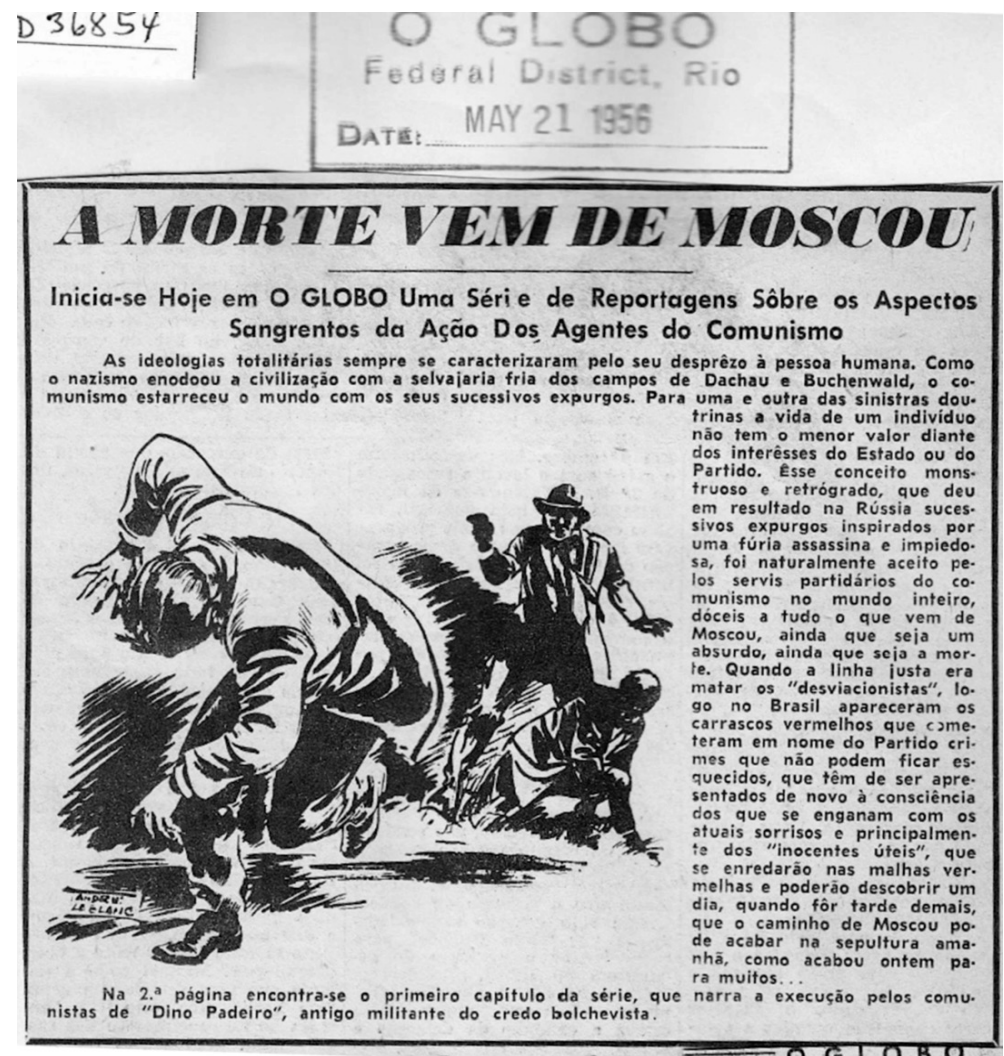

Figura 43 - Série de reportagens do Departamento de imprensa da USIA publicada em O Globo, chamada "A morte vem de Moscou”, de 21 a 28 de maio de 1956.

Encontradas entre as reportagens publicadas pelo Departamento de Imprensa dos USIS brasileiros nos arquivos da USIA em College Park, a série de artigos intitulados "A Morte Vem de Moscou", contada em $O$ Globo, com ilustrações de André Le Blanc e sem assinatura de reportagem, teve seis "episódios", de 21 a 28 de maio de $1956 .{ }^{142}$

A série contava a história de assassinatos ligados a agentes comunistas no Brasil e no mundo. Em sua primeira reportagem, a série comparava o comunismo ao nazismo e contava a história de um

142 Documento 98. 
padeiro ligado ao comunismo, que com outros membros do Partido Comunista, e a mando de Luiz Carlos Prestes, teriam "executado brutalmente" a jovem Elza Fernandes. ${ }^{143}$

A terceira reportagem contava a história de uma menor de idade conhecida como "Nelly", que por se apaixonar por um comunista foi também assassinada. A quarta reportagem contava a história do assassinato de um taxista, que teria ocorrido pelas costas, por comunistas que tinham assassinado a jovem Nelly. Com a manchete "Inocente Chefe de Família, Vítima do Instituto Sanguinário Dos Comunistas”, trazia como subtítulo “'Paulista' Foi Assassinado Apenas Porque Conduziu em Seu Táxi os Executores de 'Neli' - Rememorando um Crime Que Chocou Profundamente os Sentimentos Cristãos da Família Brasileira".

A sexta e última reportagem da série, contava a história de Trotsky no México, que a mando de Stálin, também fora assassinado pelas costas.

Como já apontava o Country Plan da USIA em 1953, os USIS no Brasil também se preocupavam em atingir os diversos jornais, com diferentes públicos. Para isso a USIA também preparava suplementos para menores jornais regionais, como "A Gazeta Comercial", de Juiz de Fora (MG), ou "A Gazeta”, de Santa Cruz do Sul (RS). Os suplementos, como o "Desfile do Mundo para o seu Lar", misturavam temas católicos, com variedades ligadas ao estilo de vida americano e por fim, atualidades mundiais, sempre com a perspectiva americana.

A capa do suplemento "Desfile do Mundo para o seu Lar" de abril de 1957, a seguir, falava sobre a quaresma. Esse documento foi encontrado nos arquivos da seção de imprensa do USIS Rio de Janeiro, entre jornais e suplementos também produzidos pela USIA no Brasil.

A publicação da USIA, dedicada a jornais de cidade do interior, falava em sua capa principalmente aos católicos: "Com a aproximação da Quaresma, as pessoas de boa vontade voltam seus corações para a Grande Tragédia, orando fervorosamente para que

143 Documento 98. 


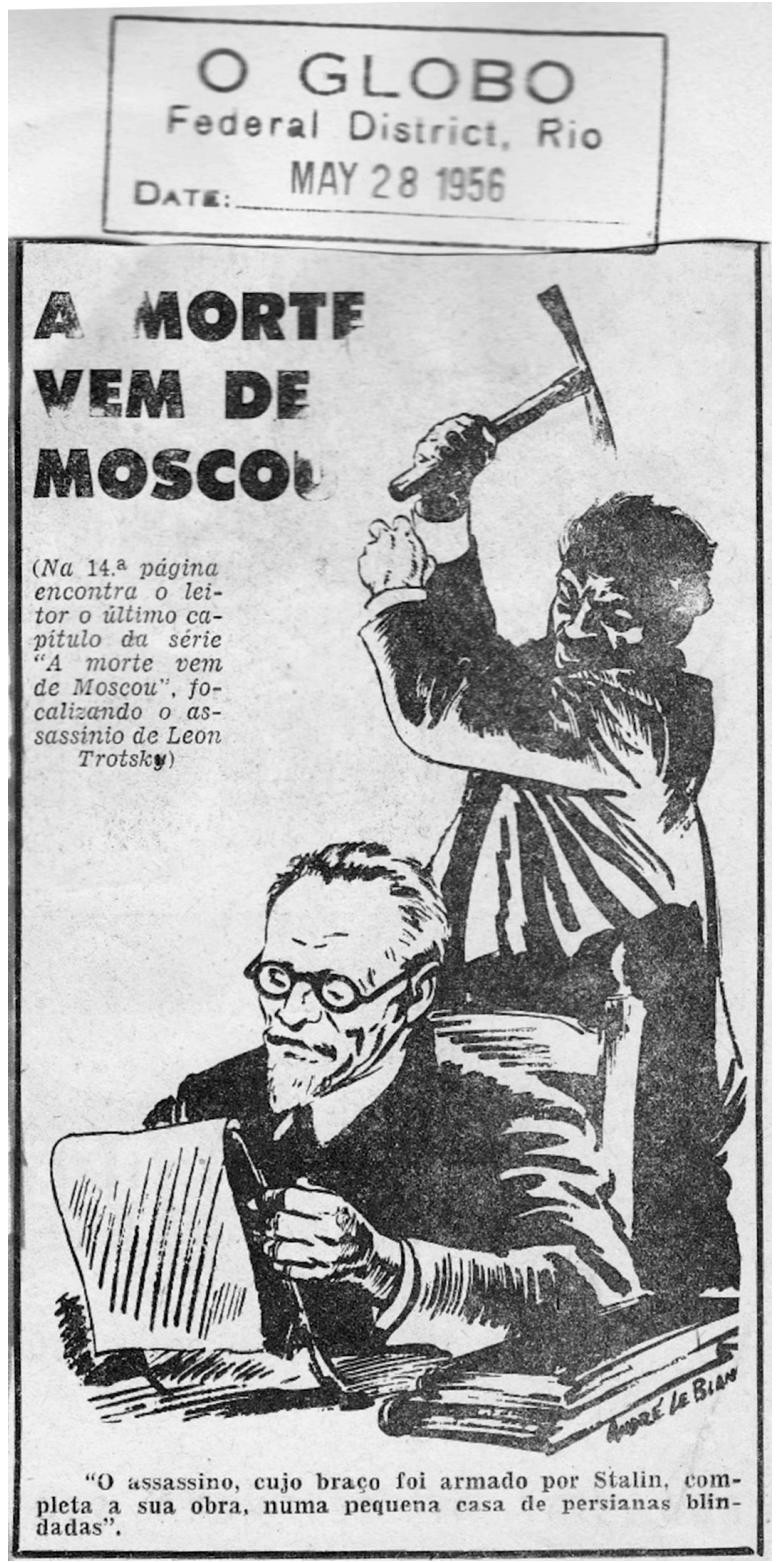

Figura 44 - Última reportagem de "A morte vem de Moscou", publicada em $O$ Globo, em 28 de maio de 1956. 


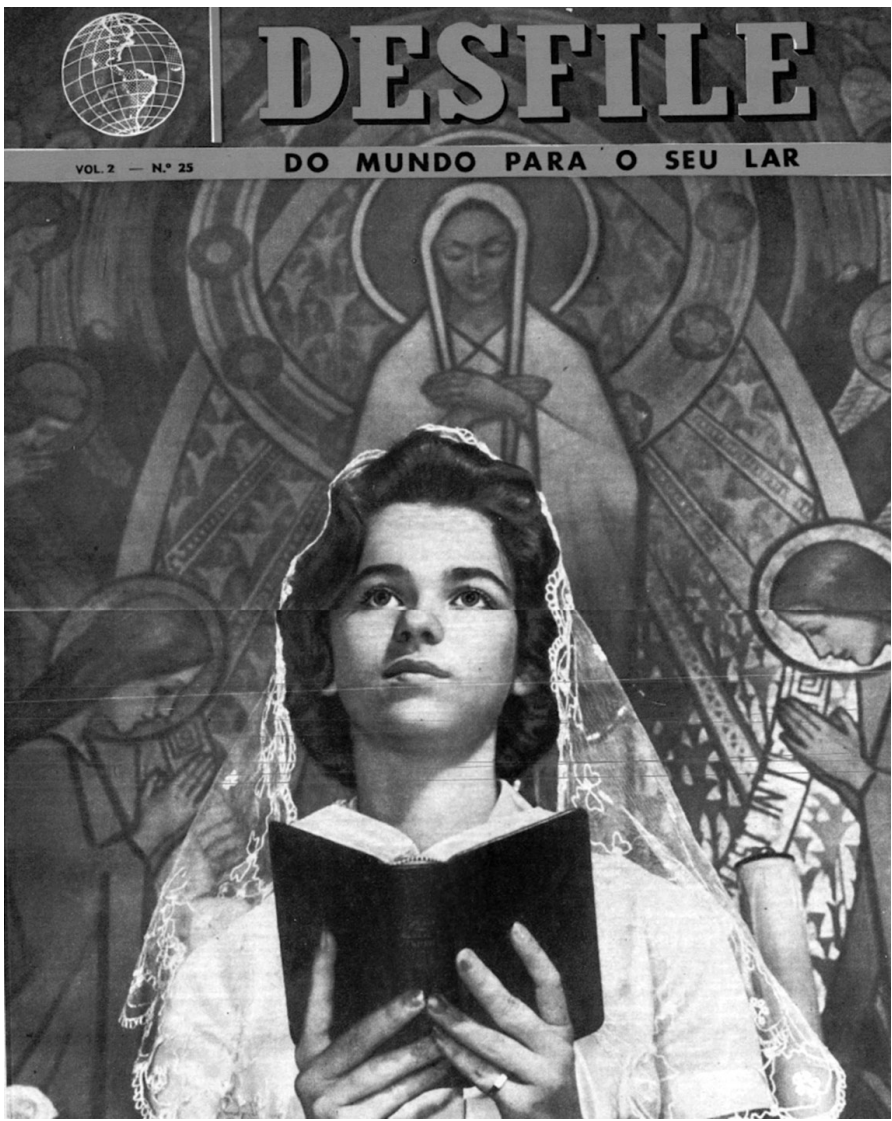

Figura 45 - Capa do suplemento "Desfile do mundo para o seu Lar", de abril de 1957, que falava sobre a quaresma.

o sacrifício do Filho de Deus não tenha sido em vão, e Sua glória ilumine as decisões dos responsáveis pela paz entre os homens" e junto ao subtítulo da capa, o anúncio de uma reportagem sobre esculturas da "Via Crucis", no interior do encarte.

Dentro do suplemento, ao lado da matéria sobre as esculturas religiosas, havia uma reportagem sobre uma jovem brasileira que ganhou uma bolsa do jornal Herald Tribune para ir aos EUA. Norma, como se chamava, havia tido muito sucesso por lá tocando trompete (sambas, gafieiras e jazz), participando de trabalhos comunitários, 
dando palestras sobre o Brasil nas escolas e até ganhando cerca de US\$ 6 mil, em um famoso programa de TV americano chamado "Qual o nome da Música?".

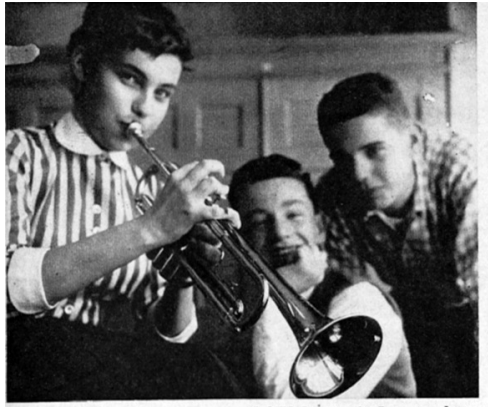

Na kala do
epistons.

\section{NORMA ACEHTDU “EM CHIEID"}

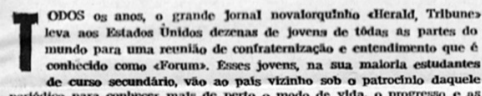
peribition para contwerer mass de perto o modo de vida, o progrenso e as

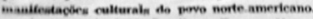

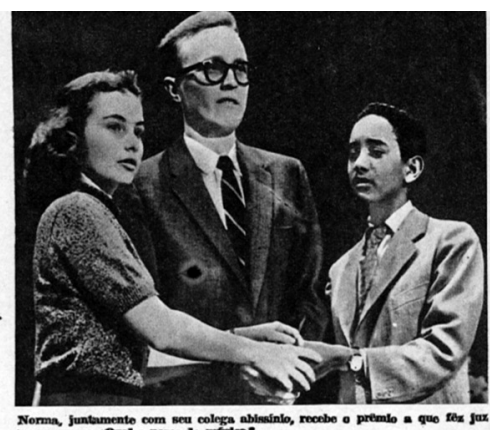

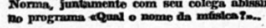

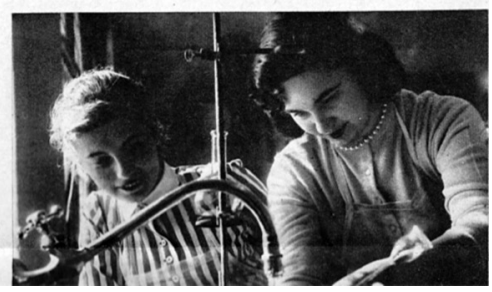

Figura 46 - Reportagem do suplemento "Desfile do mundo para o seu Lar", de abril de 1957, com reportagens sobre trompetista brasileira que visitava os EUA.

$\mathrm{Na}$ última página do suplemento eram contadas as últimas notícias "internacionais", todas relacionadas aos EUA, nenhuma delas ao Brasil. A primeira apresentava o novo submarino nuclear americano em partida para uma viagem "experimental". A segunda descrevia o novo helicóptero do Presidente americano, com luxuosos quatro lugares. A terceira e última mostrava a foto do próprio Presidente Eisenhower, em um "momento histórico", assinando a resolução que estabelecia a "Doutrina para o Oriente Médio", para "garantir a paz" naquela região.

Os dois exemplos dados de suplementos e série de reportagens da USIA em jornais brasileiros eram voltadas para públicos diferentes. O primeiro, em O Globo, de circulação nacional, mas com maior público principalmente no Rio de Janeiro, apresentava uma das linha 


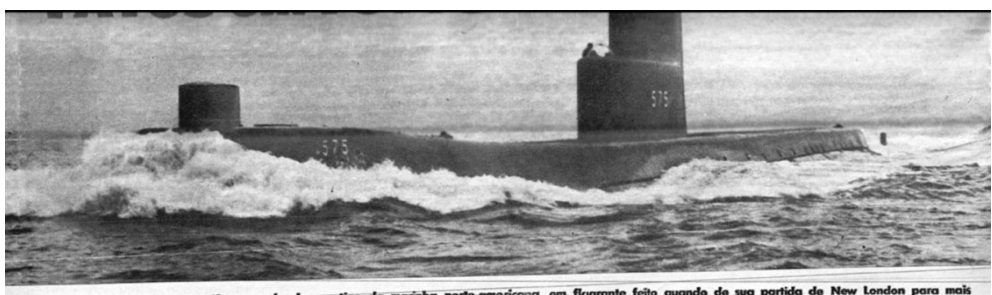

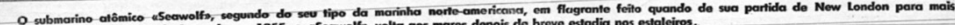

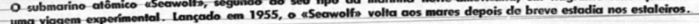

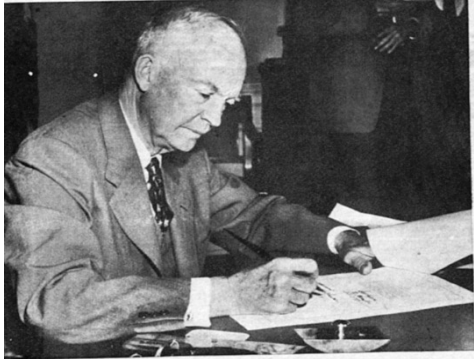

ava à resoluçāo do Congresso que ostabelece a
a defesa da parz naquela área.

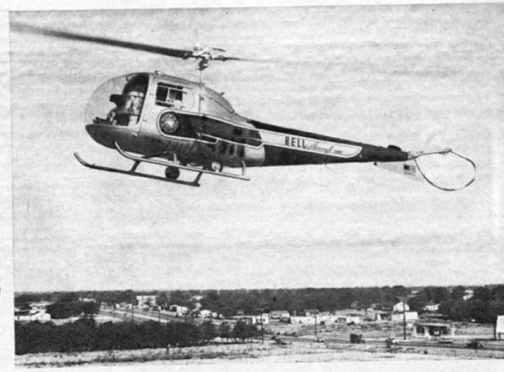

O govîrno norte-americano anunciou recentemente a aquisişăo de um heliḉpdo aparêtho a ser adquirido para tal fim.

Figura 47 - Reportagem sobre atualidades mundiais, com destaque para o Presidente Eisenhower, no suplemento "Desfile do mundo para o seu Lar", em abril de 1957 .

editoriais da USIA nos jornais brasileiros: o anticomunismo. A segunda apresentava outro perfil entre as publicações da USIA, voltado para jornais regionais e mesclando valores cristãos, com reportagens de variedades que exaltavam o estilo de vida americano; e, por fim, os feitos da política externa americana com uma perspectiva positiva.

Em comum, entre os dois tipos de reportagem da agência estava um dos grandes princípios do modo USIA de agir nos meios de comunicação de massa: a não-assinatura de suas produções. ${ }^{144}$ Isso, segundo suas pesquisas de mercado, mostravam-nas menos tendenciosas, e portanto mais eficazes por não deixar nenhum rastro de intervenção governamental americana.

144 Mais sobre o princípio de anonimato nas produções da USIA em Bogart (1995, pp.114-5, 123). 


\section{Problemas do Comunismo \\ NÚMERO
SETEMBRO-OUTUBRO
VOL. I
1956}

\section{Acontecimentos Atuais}

o Vigésimo Congresso e Depois

Anatomia da Tirania : O Ataque do Sr. Khrushchev

contra Stalin ............................ 1

Três Caminhos Para o Poder,

por Richard Lowenthal ....................... 9

Bulganin e Khrushchev na Grä-Bretanha,

por Denis Healey $\ldots \ldots \ldots \ldots \ldots \ldots \ldots \ldots \ldots \ldots \ldots \ldots \ldots \ldots$

\section{Uniâo Soviética}

Rumos Recentes na Política Trabalhista Soviética,

por Jerzy G. Gliksman ........................ 20

Nova Era na Arquitetura Soviética?,

por Paut Willen ............................... 29

\section{China}

Trabalho Forçado na China Comunista,

por Karl A. Wittfogel

\section{Livros}

Utopias e Realidades

Sidney Hook: Marx e os Marxistas, e

Daniel Norman: Marx e a Realidade Soviética,

revistos por Ben B. Seligman .................... 42

A Longa Viagem de Volta

Wolfgang Leonhard: A Revolução Repudia os seus Filhos,

revisto por Marianne Pollak .......................44

\section{Notas e Comentários}

Estudos Recentes Sôbre Assuntos Comunistas

Figura 48 - Textos da revista "Problemas do Comunismo", publicação mundial da USIA, no Brasil distribuída pela Editora Ipanema, sem assinatura da agência, de setembro de 1956.

Outro tipo de publicação da USIA era a revista bimensal "Problemas do Comunismo", ${ }^{145}$ voltado para um público mais elaborado e formador de opinião, com reportagens mais aprofundadas e densas, apresentando dados estatísticos e menos ilustrações. 
Seus artigos, de acadêmicos e especialistas ilustres, sempre desmitificavam dados sobre a União Soviética e a China Comunista e tinham livres direitos de reprodução (curiosamente com exceção para os EUA e Canadá). Mais uma vez a marca da USIA não aparecia como produtora do material, que era assinada no Brasil pela Editora Ipanema. Essa revista era também reproduzida em várias línguas, em todos os continentes, mas nunca com a marca da USIA. ${ }^{146}$

$\mathrm{O}$ anonimato era uma das condições para o uso das notícias e materiais distribuídos pela USIA. Em seu boletim diário de notícias, ao invés de condicionar a reprodução à citação da fonte, liberava o uso apenas quando não fosse citada a fonte: "A reedição dos artigos publicados nêste boletim, sem mencionar a fonte, é permitida”.

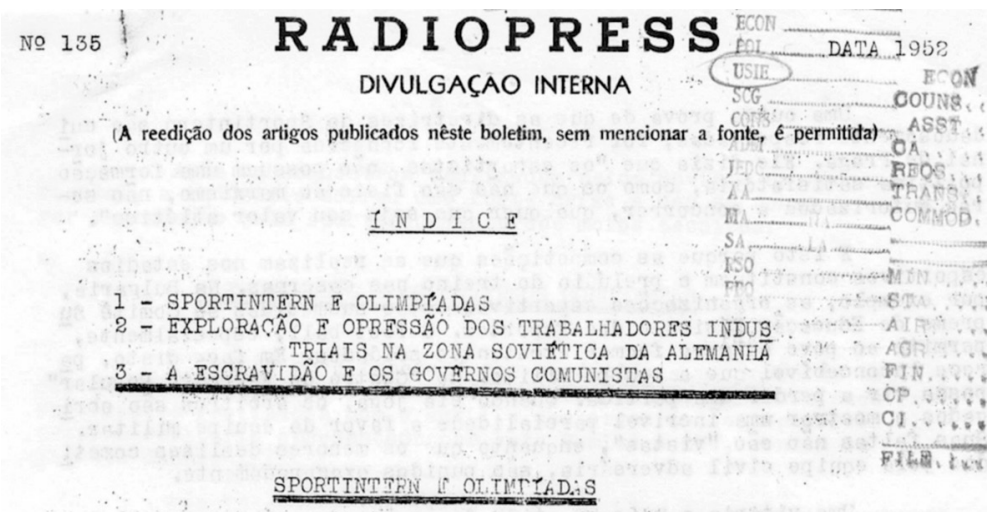
O treino dos atletas soviéticos e dos países satélites per
mictiu aos comuniatas, pouco antes das recentes olimpladas realiza-
das em Helsinki, reforcarem a acão de controle nue a nragini zacã in

Figura 49 - Boletim de notícias da USIA: não mencionar a fonte era requisito para a utilização dos materiais.

O próprio Streitbert, diretor da USIA em 1954, declarava no Congresso norte-americano que o anonimato era condição básica para a aceitação do público nos jornais, por exemplo, dos quadrinhos: "Se os leitores dos jornais que publicam esses quadrinhos 
soubessem que eles foram produzidos para nossos propósitos, os jornais talvez não os utilizassem mais". ${ }^{147}$

Em pesquisa interna sobre a eficácia da distribuição e do uso das notícias da USIA nos jornais, revistas, rádios e televisões brasileiras em 1959, ${ }^{148}$ descobria-se que, apesar do maior atraso em lugares mais longínquos como o Norte e interior do Brasil, as notícias chegavam a todas as regiões brasileiras, e diariamente no Rio de Janeiro e em São Paulo: "A grande maioria dos veículos pesquisados - quatro entre cinco jornais, nove entre dez radialistas, e mais do que três entre cinco revistas - relataram receber os materiais dos USIS ". 149

O uso das notícias era também satisfatório, principalmente nas cidades capitais, no Norte, em rádios e TVs, onde o uso apresentava-se proporcionalmente maior: "Enquanto a maioria dos veículos que recebem os materiais da USIS usam menos do que a metade do que eles têm, quase um terço das estações de rádio e TV cobertas pela pesquisa usam mais do que $50 \%$ do material; essa percentagem é ainda mais alta nas cidades capitais e no norte". ${ }^{150}$

Além da eficiente distribuição, a USIA no Brasil também contava com aliados de peso para difundir suas notícias, como o já mencionado Assis Chateaubriand e jornalistas declaradamente pró-americanos como Carlos Lacerda, Pereira Carneiro e Paulo Bittencourt. Assim como esses, havia as organizações como a Agência Nacional, ${ }^{151}$ que "plantavam" matérias e/ou editoriais (muitas vezes com pseudônimos) em jornais de grandes circulação como $O$ Globo, ${ }^{152}$ Correio da Manhã, Tribuna de Imprensa ${ }^{153}$ e revistas como

147 Documento 112

148 Documento 78: "Utilization and Opinions of USIS Brazil - Media Press Services, 1959".

149 Documento 78.

150 Documento 78.

151 Esses citados nominalmente pelo historiador da CIA, Haines (1989, p.168).

152 Artigos apócrifos ou editoriais assinados por pseudônimos em $O$ Globo e $O$ Cruzeiro também citados em Haines (1989, p.169).

153 Sobre o trabalho da USIA no Correio da Manhã e Tribuna de Imprensa é referência o pioneiro sobre a USIA no Brasil, dissertação de mestrado defendida na USP, por Cattai (2011). 
O Cruzeiro. Em listagem secreta da USIA de 1958, indicavam-se os jornais e revistas mais importantes do Brasil, com quem a agência poderia contar:

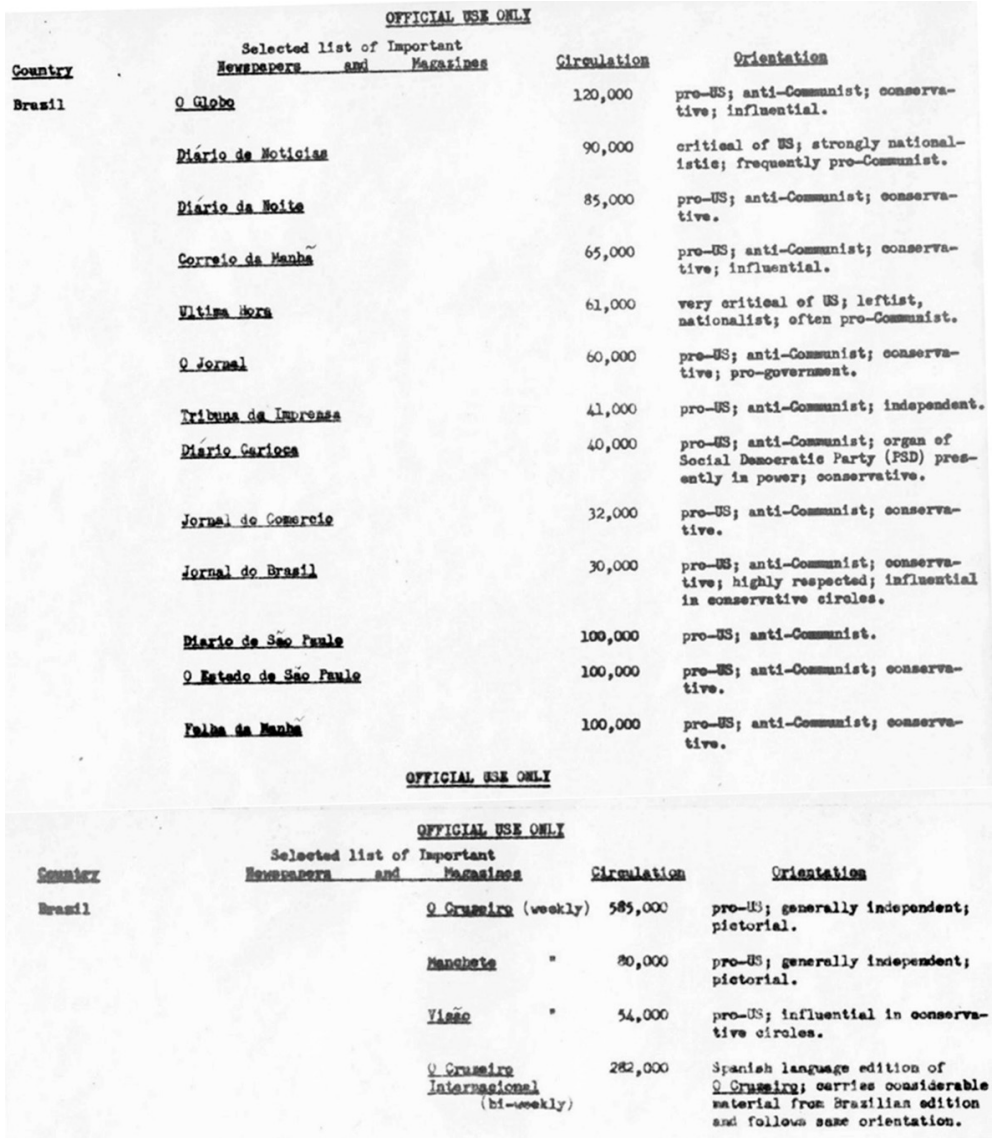

Figura 50 - Lista da USIA sobre órgãos importantes de imprensa não comunista no Brasil, em 1958.

A partir do governo Kennedy, com a mudança de foco da USIA para o Brasil, restringindo a sua atenção principalmente a estudantes, trabalhadores urbanos e rurais, principalmente no Nordeste, as publicações dos USIS também se diversificaram e dedicaram-se à 
produção de materiais especiais para esses públicos. O trabalho com os maiores jornais e revistas do País, porém, se manteve.

Além da figura do Presidente e de sua família, os novos programas de JFK, como o Peace Corps, por exemplo, continuaram a ser elogiados pelos jornais brasileiros com maior circulação. Segundo levantamento da USIA, em 1961:

Exceto Cuba, a reação da imprensa latino-americana foi extremamente favorável. No Brasil, o Jornal do Commercio aplaudia a ideia e dizia que o "corps" permitiria que os jovens da América do Norte "pusessem em prática suas ideias democráticas, fraternidade humana e a dignidade do trabalho por meio dos contatos interpessoais". ${ }^{154}$

A partir de 1963, os "latino barômetros" também começaram a apontar uma mudança de postura em relação governo brasileiro de Goulart. No levantamento da USIA em setembro de 1963, as críticas dos jornais brasileiros (ou de correspondentes desses jornais) eram motivo de preocupação para a agência. $\mathrm{O}$ correspondente do Jornal do Brasil nos EUA, Nahum Sirotsky, relatou uma situação de grave crise política no governo brasileiro à USIA de Murrow. ${ }^{155}$

O Estado de S. Paulo também demonstrava a crise vivida por Jango, segundo a USIA:

Goulart está desesperado, de acordo com o normalmente confiável Estado de São Paulo, e ameaça a começar as expropriações de terra com indenização em dinheiro. ...O Estado de São Paulo sugere o rompimento aberto entre os normalmente aliados PTB (Partido Trabalhista $=$ Goulart $)$ e o PSD. Enquanto isso, Kubitschek, o líder nas pesquisas para Presidente em " 65 , admite a possibilidade [de se candidatar] . ${ }^{156}$

Mesmo com a morte de Kennedy, os jornais brasileiros de maior circulação continuaram, no geral, a elogiar o seu sucessor, Lyndon

154 Documento 101.

155 Documento 102.

156 Documento 102. 
Johnson. Segundo relatório da USIA em janeiro de 1964, o "Estado de S. Paulo" dedicou de 20 a 27 de dezembro uma cobertura exclusiva do primeiro mês de Johnson na presidência, descrevendo-o como um "um político profissional [...], um dos mais talentosos articuladores táticos do Congresso". ${ }^{157}$

Ao mesmo tempo, o relatório da agência destacava a postura crítica do jornal em relação a Goulart, que atrapalharia a aproximação dos EUA com a América Latina: "Neste mais delicado momento da história brasileira, há um grupo que não pensa, esforçando-se para impedir a realização das aspirações da nação". ${ }^{158}$

Após o primeiro mês de mandato de Johnson, $O$ Estado de $S$. Paulo publicava um editorial que fechava a série de reportagens especiais sobre o novo Presidente americano, em 27 de dezembro de 1963, intitulado "The First Thirty Days of Lyndon Johnson" (Os primeiros trinta dias de Lyndon Johnson). A USIA caracterizava o editorial, publicado quatro meses antes do golpe, como "elogios efusivos ao Presidente Johnson e uma expressão da mais alta confiança na sua habilidade em 'defender a civilização e garantir a paz". ${ }^{159}$

É interessante notar que após o golpe militar de primeiro de abril de 1964, a USIA encomendou uma pesquisa sobre "Como os profissionais da mídia de massa afetam o processo político e porque eles agem dessa maneira para alcançar o efeito desejado", ${ }^{160}$ com base em entrevistas das pessoas responsáveis pelos meios de comunicação mais influentes do país. A conclusão a que o estudo chegava era de que os grandes meios de comunicação do Brasil eram empresas familiares, que refletiam a posição social (abastada) de seus proprietários:

[...] os jornais politicamente importantes do Brasil não são instituições impessoais. A maioria reflete suas opiniões gerais de acordo com a posição de seu dono, que circula entre os círculos sociais mais altos. O resultado disso é que as ideias são normalmente as clássicas

157 Documento 102.

158 Documento 102.

159 Documento 102.

160 Documento 83: "BR 6403, Brazil Effect of Media on Politics, 1964". 
liberais, ao invés das marxistas, e os seus interesses são normalmente conservadores, ao invés de revolucionários. [...] Os jornalistas são independentes até onde o diretor permitir. ${ }^{161}$

Mesmo com as denúncias públicas de possíveis participações estrangeiras em publicações dos "Diários Associados" (que já entrava em crise financeira), da editora Abril, do Reader's Digest e do acordo da Time-Life com a Globo, em 1966, as atividades dos USIS não foram denunciadas e continuaram normalmente: Segundo telegrama interno da USIA: "houve uma pequena menção na imprensa ao programa de livros da USAID mas sem citar os USIS. Sem sinal, ainda, de nenhum ataque [...] o Cruzeiro e a TV Tupi continuam usando o material dos USIS". ${ }^{162}$

Por isso, o trabalho dos USIS com a imprensa continuou. Ainda em 1982, estudos mencionavam publicações brasileiras que usavam material anticomunista da USIA, como o "Jornal da Tarde", que publicou uma série de charges humorísticas satirizando as promessas não cumpridas da URSS, aproveitando das dificuldades internas do bloco no início dos anos 1980. ${ }^{163}$

A mídia tradicional, porém, não foi a única frente da USIA para influenciar os diferentes grupos no Brasil. Para cada grupo a ser atingido, seja nas grandes cidades ou no interior, a agência tinha uma tática especial para os estudantes, trabalhadores das cidades ou do campo e para as favelas.

\section{Os programas para os grupos prioritários: estudantes, trabalhadores urbanos e rurais}

Além dos grupos dominantes politicamente, economicamente e formadores de opinião - como jornalistas, artistas e intelectuais - era

161 Documento 83: "BR 6403, Brazil Effect of Media on Politics, 1964".

162 Descritos em relatórios confidenciais do Departamento de Estado naquele ano, em Documento 104.

163 Cull (2008, p.424). 
fundamental para a USIA a mobilização de grupos emergentes e potenciais transformadores da ordem vigente. Eram esses os estudantes, os trabalhadores da cidade e do campo. ${ }^{164}$ Isso considerando o contexto de instabilidade política em um país jovem em ampla transformação como o Brasil dos anos 1950 e 1960.

Entre esses grupos, os naturalmente afetados pela estrutura da USIA no Brasil (centros binacionais, com bibliotecas e escolas de inglês) eram os estudantes, alvos por excelência das políticas da agência. Como visto no subcapítulo 3.1, os estudantes brasileiros eram alvo constante de pesquisas quantitativas e qualitativas, de modo que se formulassem as medidas mais adequadas para esse grupo, um dos mais antiamericanos do país e mais pró-comunistas.

As políticas de atração dos jovens estudantes eram realizadas por meio da educação e da cultura. O lado educacional contava com o ensino da língua, com a disponibilização de livros americanos a preços atrativos (subsidiados), ou locados em bibliotecas dos USIS, e com as bolsas de estudo para jovens promissores. A frente cultural promovia a exibição de filmes, a transmissão de programas com as músicas americanas nas principais estações de rádio brasileiras e a organização de feiras e exibições de assuntos de interesse americano, como o uso pacífico da energia nuclear ou com os feitos espaciais americanos.

Para a difusão de livros americanos, ao longo dos anos 1950 e 1960, a USIA desenvolveu um programa de tradução de obras selecionadas, que eram subsidiadas e voltadas para o público estudantil. ${ }^{165}$ Entre 1950 a 1963, foram traduzidos ao português livros que contavam o progresso americano em temas como eletrônica, eletricidade, energia atômica, desenvolvimento econômico. Também eram destaque biografias de grandes heróis americanos, como Eleonor Roosevelt, Abraham Lincoln e clássicos internacionais como "Moby Dick", "Animal Farm" e "A Democracia na América".

164 Sobre os critérios de definição dos grupos prioritários da USIA, ver Bogart, 1995 , p. 55 .

165 Documento 105. 


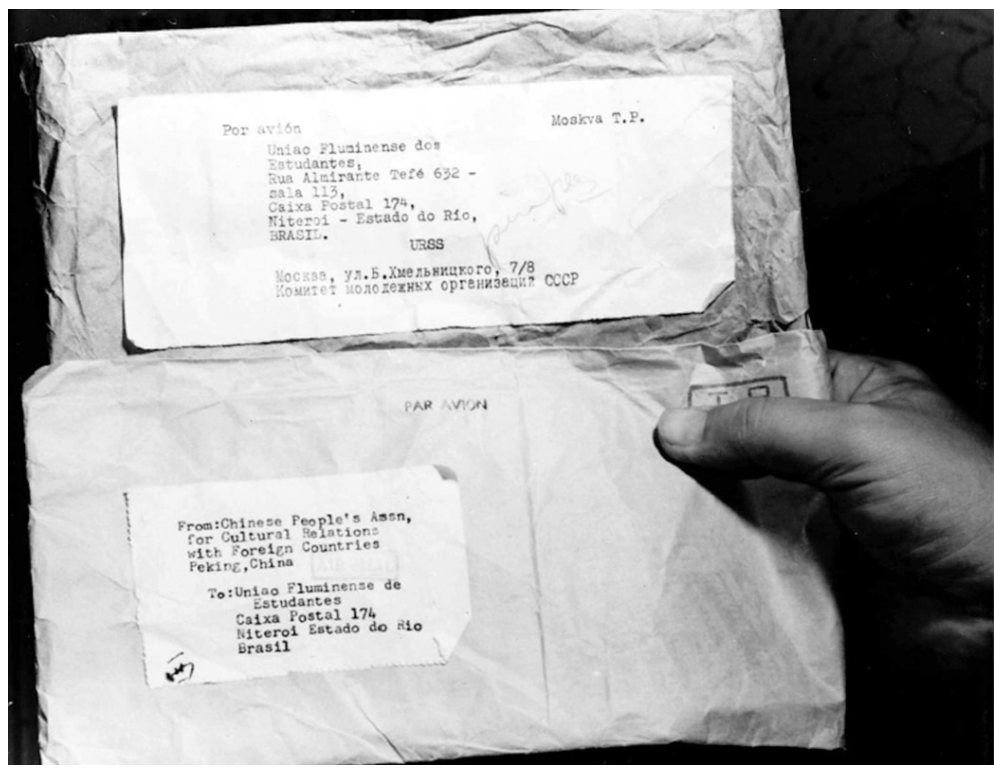

Figura 51 - Os estudantes na mira da USIA: foto de correspondências entre a União Estadual dos Estudantes Fluminenses e o Partido Comunista Chinês, tirada pelo USIS/Rio de Janeiro, após o golpe militar.

Outros temas recorrentes entre as publicações traduzidas e distribuídas pela agência eram os que criticavam o regime comunista, como "Tempestade sobre o mundo: A morte da liberdade na Rússia", "Mestres do Embuste" e "A Condição Humana na China Comunista". Nos anos 1950 e 1960, a USIA traduziu e distribuiu no Brasil obras de Ernest Hemingway, J. Edgar Hoover e Raymond Aron. Os preços ao consumidor final variavam de 50 centavos de dólar a US\$ 3 dólares. ${ }^{166}$

Além de facilitar a exportação de livros por meio do Informational Guaranty Media Program, auxiliando as editoras americanas na venda de livros no Brasil a partir de 1954, a USIA também agia como intermediária e facilitadora para publicação de seus livros por editoras brasileiras.

166 Documento 105. 
Roberto Gonzaga, chefe de imprensa do USIS no Rio de Janeiro, intermediava as negociações com editoras brasileiras e as encaminhava para Dr. Gordon Brown, CAO-USIS/Rio, responsável pelos contratos com editoras brasileiras. Em um desses casos, ${ }^{167}$ Gonzaga teria cobrado do jornalista e escritor Lúcio Rangel cerca de Cr\$ 8 mil cruzeiros pelo direito de publicação de quatro livros da USIA, o que normalmente não fazia parte do procedimento da agência.

Saldanha Coelho, outro célebre jornalista da época e ligado a Rangel, denunciou o ocorrido à Embaixada americana, que abriu investigação interna para julgar o caso da "gratificação" pedida por Gonzaga. Segundo depoimento por escrito de Rangel, ele havia entregado o dinheiro, em mãos, ao chefe do Departamento de imprensa do USIS/Rio, em um café na frente da Embaixada americana. O fato foi negado por Gonzaga, que teria dito que tal valor teria sido repassado a Rodrigo Miranda, outro funcionário do USIS Rio, para os serviços de tradução de livros americanos. ${ }^{168}$

Para Gonzaga, chefe de imprensa do USIS/Rio, Lúcio Rangel seria um testa de ferro de Saldanha Coelho, para conseguir direitos de livros da USIS para outras editoras: "Durante o processo de inquérito, Roberto Gonzaga declarou acreditar que ele poderia provar que Lúcio Rangel era só um 'parceiro silencioso' ou um 'testa de ferro' de Saldanha Coelho no mercado editorial, [...] e que Saldanha estava tentando usar Rangel para deslegitimar Gonzaga”. ${ }^{169}$

Lúcio Rangel foi consultado pelo Departamento de Inspeção da USIA na própria sede da editora Alvorada-Edições de Arte, da qual ele era editor, e manteve sua história original:"o Sr. Dickinson encontrou o Sr. Rangel no escritório do último, na Travessa do Ouvidor, 27, às 2:10 daquela tarde. O Sr. Rangel continuou a afirmar que ele deu Cr\$ 8.000 a Roberto Gonzaga [...] Ele repetidamente

167 Descrito em informe interno do Departamento de inspeção da USIA, em 9 de setembro de 1955, Documento 74: "Record of Meeting in Mr. Vebber's Office - September 9, 1955".

168 Documento 74.

169 Documento 74. 
declarou que conhecia Roberto Gonzaga e que foi ele que havia recebido o dinheiro". ${ }^{170}$

O fato é que os USIS tinham contato direto com figuras de destaque no meio editorial brasileiro da época, como Rangel e Saldanha Coelho e, como visto, assistia à cerrada concorrência das editoras nacionais para a publicação de seus livros.

Os livros americanos eram disponíveis também para aqueles que não quisessem comprá-los, sendo acessíveis nas bibliotecas espalhadas pelo País, que configuravam a célula inicial da presença física americana no Brasil. Além dos livros, as bibliotecas eram centros de encontro e sedes físicas para cursos de línguas e outras atividades. ${ }^{171}$

Para os estudantes que se destacavam como maiores potenciais lideranças em suas áreas de atuação, eram oferecidas bolsas de estudo para os EUA. Em 1953, 61 estudantes na faixa dos 30 anos, em sua maioria de São Paulo (34 paulistas), e o restante do Rio de Janeiro foram escolhidos como bolsistas. ${ }^{172} \mathrm{Um}$ quarto desses era considerado da classe mais alta e os outros da classe "B".

A maioria dos estudantes era da área de ciências humanas e sociais. Segundo pesquisa feita com os bolsistas depois de seus regressos ao País, ${ }^{173}$ a avaliação dos EUA e de seu modo de vida era mais alta entre os estudantes que foram aos EUA do que a dos estudantes brasileiros, das mesmas áreas, que ficaram no Brasil:

Sobre as atitudes em relação aos americanos e ao estilo de vida americano, não há dúvidas de que o efeito automático de suas visitas foi favorável. Esta conclusão é baseada não só no que os bolsistas relataram, mas também comparando as suas opiniões com as de um outro grupo de brasileiros, que não fizeram a viagem aos Estados Unidos. ${ }^{174}$

170 Documento 74.

171 Mais sobre a importância das bibliotecas na estratégia da USIA na América Latina em Bogart, (1995, p.25).

172 Documento 106.

173 Documento 106.

174 Documento 106. 
Outra característica observável pela pesquisa era que os ex-bolsistas brasileiros tornavam-se defensores e promotores da boa imagem americana em seus campos de atuação:

O ponto mais interessante deste estudo foi o de como os bolsistas que retornaram tornam-se emissários ou fontes de informação sobre os Estados Unidos nas suas comunidades [...] todo bolsista acaba sendo considerando como uma autoridade sobre os Estados Unidos, pelo menos em alguns assuntos e em certos círculos". ${ }^{175}$

Um segundo grupo prioritário para a USIA em um Brasil em crescimento era o de trabalhadores urbanos, que se apresentavam como foco potencial de comunismo, inclusive com ligações com o PTB de Jango por causa do formato "tutelado" que os sindicatos brasileiros foram formados desde Getúlio. No planejamento da USIA para o biênio de 1954-1955, essa importância estratégica do Trabalho era destacada: "O Trabalho é um dos, se não o principal, grupo alvo para o esforço comunista soviético [...] ajudado e incitado pelos agentes do peronismo, ambos com apoio substancial de um importante elemento do Partido Trabalhista Brasileiro". ${ }^{176}$

Por causa da importância da área e do potencial "comunista-peronista" dos sindicatos brasileiros, desde o Country Plan da USIA, de 1953, foi indicado a figura do "Labor Attaché", que seria responsável pela articulação com as lideranças sindicais brasileiras, pela produção de materiais anticomunistas específicos para os trabalhadores do País, em conjunto com organizações da Igreja Católica que trabalhavam com sindicatos, organizações sindicais americanas, internacionais e com a chancela do Ministério do Trabalho brasileiro da ocasião. ${ }^{177}$

Com ajuda das organizações brasileiras (algumas sem comprovação de existência) e entidades de trabalho americanas, os USIS difundiram muitos materiais por meio desses grupos. Os materiais de teor

175 Documento 106.

176 Documento 64.

177 Documento 64. 
anticomunista eram dedicados aos operários brasileiros e nenhum dos encontrados nos arquivos americanos - como revistas, quadrinhos e folhetos dos USIS brasileiros - eram assinados oficialmente pela USIA ou por qualquer órgão relacionado ao governo americano.

A série de panfletos abaixo, assinados por uma instituição chamada de "Lei e Polícia-serviço de contra propaganda" era destinada aos operários, criticando a liberdade de trabalho e política e a falta de valores religiosos no comunismo.

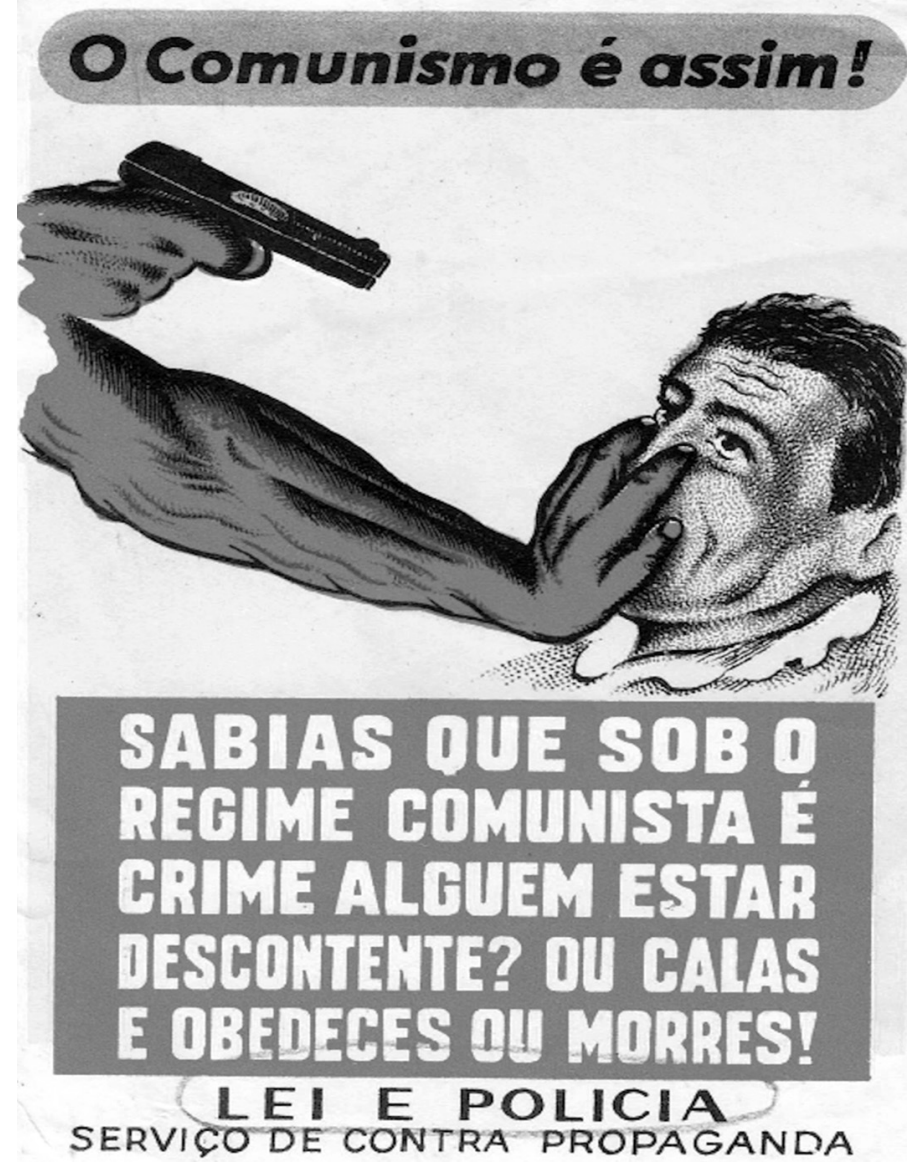

Figura 52 - Folheto anticomunista produzido pela USIA no Brasil e assinado por "Lei e Polícia - serviço de contra propaganda". 


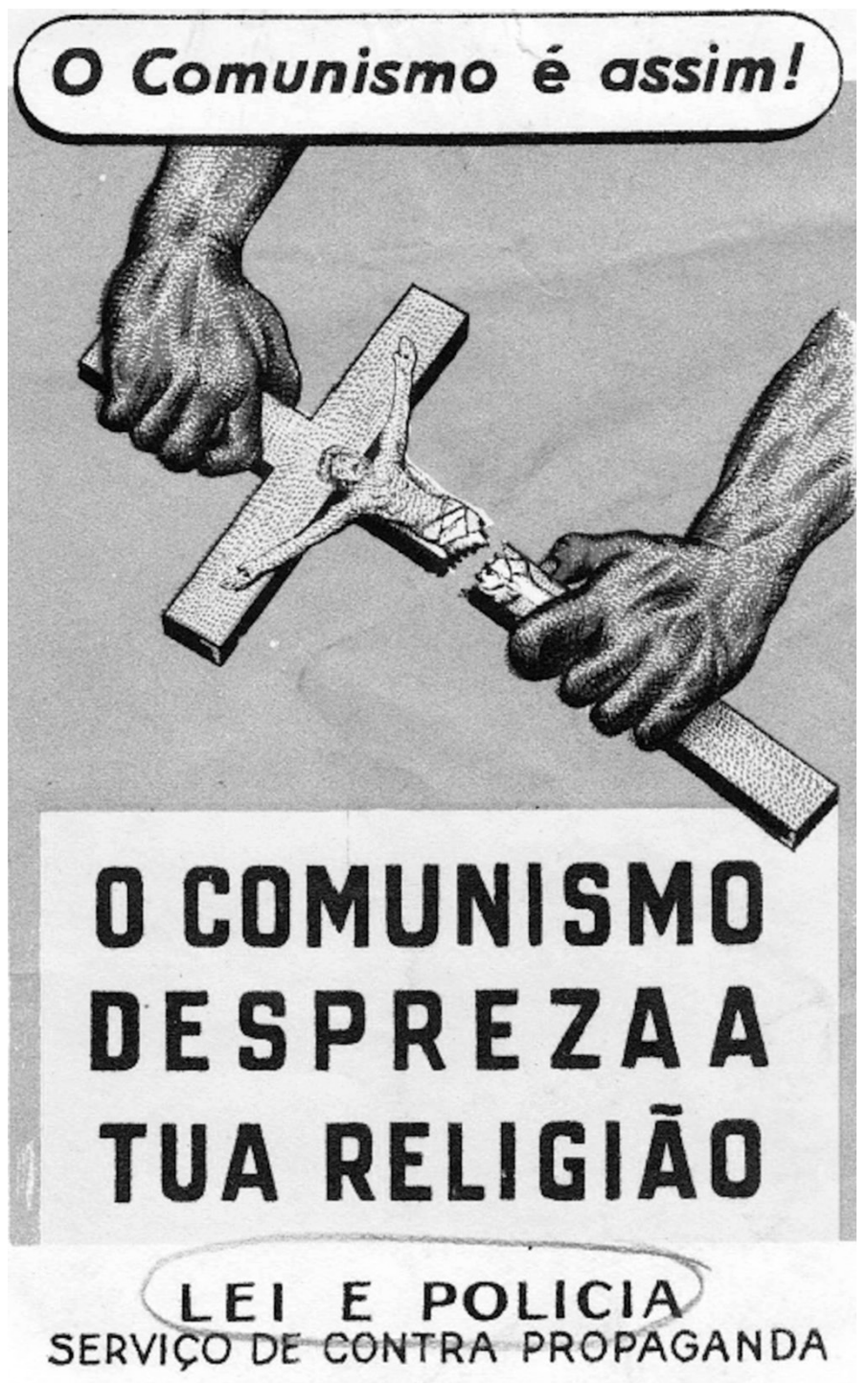

Figura 53 - Folheto anticomunista produzido pela USIA no Brasil, reforçando valores religiosos e assinado por "Lei e Polícia - serviço de contra propaganda". 


\section{Como é tratado o operário na RUSS I A}

Não há salário mínimo na Rússia. 0 operário ganha pelo que produz.

O operário russo não pode faltar co serviço, sob pencs severas.

O operário russo não tem direito de escolher o local de trabalho. Vai para onde o govêrno comunista determinar e muitcs vêzes se separa de sua família por anos a fio, pois é proibido levá-la em sua companhia.

O operário russo mora na casa que a autoridade soviética determinar, $\alpha$ qual a maioria das vêzes é anti-higiênica, pequena e sem qualquer confôrto.

O operćrio que vive na Rússia não tem direilo de tazer reclamação de espécie alguma. Quando um dêles tem a audácía de fazer isso é logo despodido. perde sua carteira profissional e, quando não vai parar na cadeic, morre de fome, porque nenhuma fábrica 0 aceita.

O operório russo é "obrigado" $\alpha$ votar no candidato do partido comunista escolhido pelo Govêrno. Do contrório o seu voto é nulo.

O operário russo é escravo do Govêno: Em 1934 foram requisitados 300 (trezentos) mil opezários para construção de uma reprêsa. Só voltaram às suas casas 71 (setenta e um) mil. Do resto ninguém teve mais notícia.

O operário russo enche os campos de concentração. A prova disso é a liberdade que Stalin concedeu em 1941 a 31 mil operários, sob a condição de se incorporarem do Exército.

"O comunismo mantém o operório russo sob um terrível regime do chicote".

Divulgação de "LEI E POLíCIA", orgão de combate ao comunismo

Figura 54 - Folheto anticomunista produzido pela USIA no Brasil, voltado para o operariado nacional e assinado por "Lei e Polícia - serviço de contra propaganda”. 


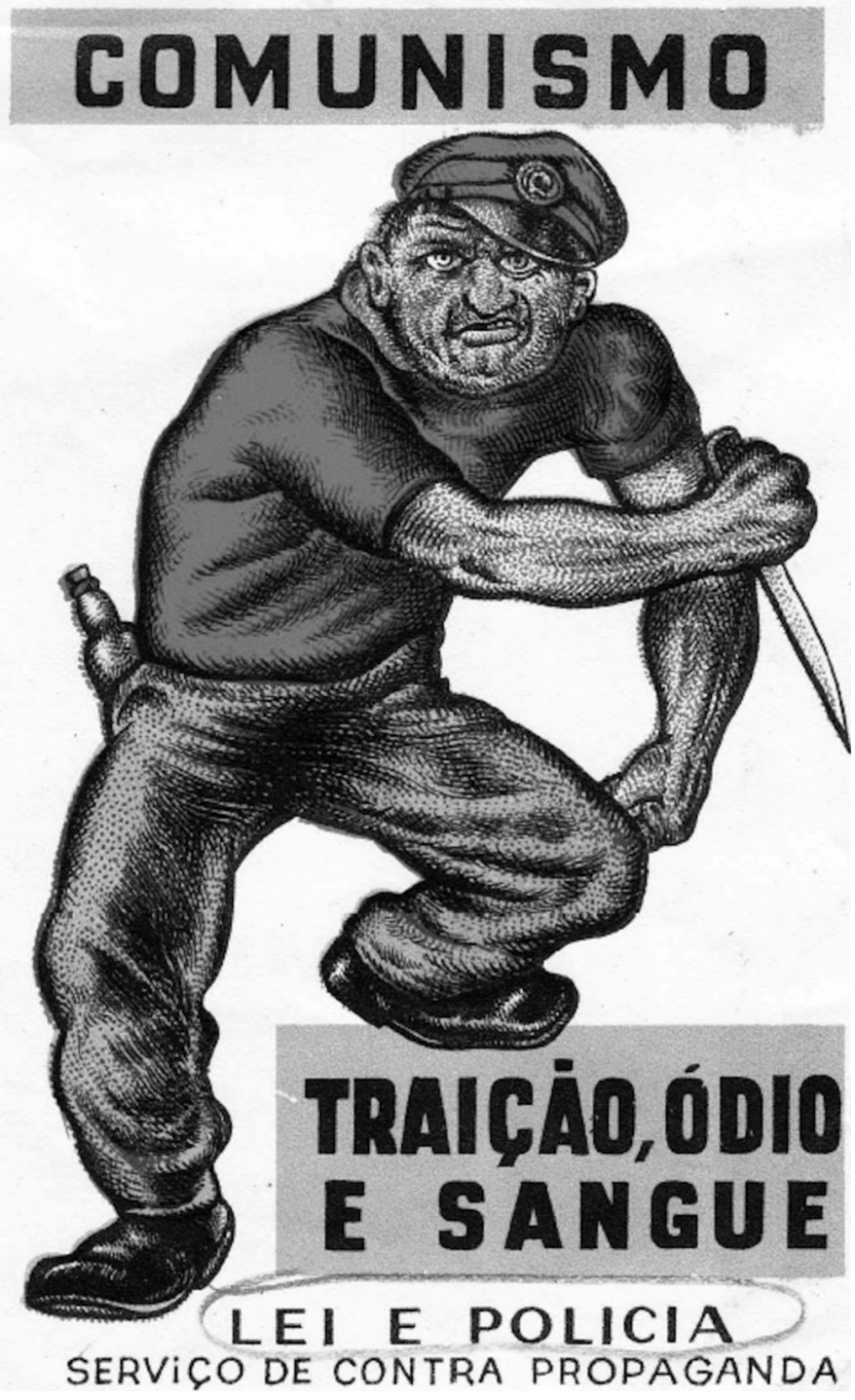

Figura 55 - Folheto anticomunista produzido pela USIA no Brasil, associando o comunismo à "Traição, Ódio e Sangue" e assinado por "Lei e Polícia - serviço de contra propaganda". 


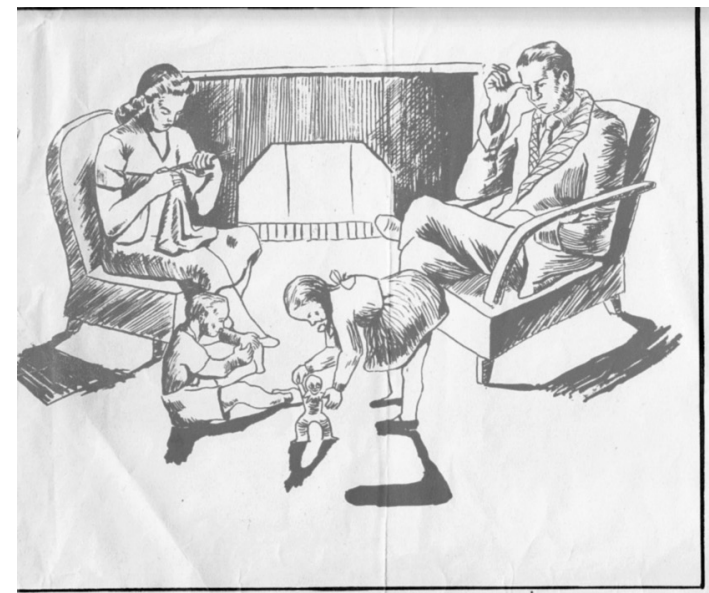

r디J드 só o que vi perderá se o Comunis triunfar. Você não por assegurar o futuro da familia... não pode rezar na sua igreja. . poderá discutir as suas idéi políticas ... não poderá trabalhar no lugar nem do modo que quiser.... você não poderá viver como HOMEM LIVRE.

O Comunismo pode, e ain acabará por destruir todas essas liberdades, se nós não PENSARMOS e TRABALHARMOS juntos COMO HOMENS LIVRES.

\section{CAMDA NYYA DE EDUCAÇÃO SOCIAL}

Figura 56 - Material anticomunista produzido pela USIA no Brasil, contrapondo o comunismo aos valores familiares e à liberdade, assinado por "Campanha de Educação Social".

O curioso é que muitos desses documentos localizados nos arquivos americanos apresentavam anotações a lápis, nos versos, com data e localização do posto da USIA no Brasil, assim como a caixa de fósforos abaixo.

A partir de 1955, os materiais da USIA, principalmente do USIS São Paulo começam a ser assinados como se fossem produzidos pela "Cruzada Brasileira Anti-comunista". Sem endereço, a cruzada apresentava uma caixa postal (910), no Rio de Janeiro.

Um ano pós a morte de Getúlio Vargas, a Cruzada Brasileira Anticomunista lançou um panfleto que tentava mostrar as "duas caras" de Luiz Carlos Prestes, no intuito de amenizar o antiamericanismo que aumentava imediatamente após o suicídio de Getúlio e desvincular o comunismo da sua imagem, ligado ao trabalhismo.

Para isso, o panfleto mostrava declarações dos comunistas brasileiros antes da morte de Vargas, quando o criticavam e alertavam o público brasileiro, em letras garrafais: "Reparem no cinismo com 

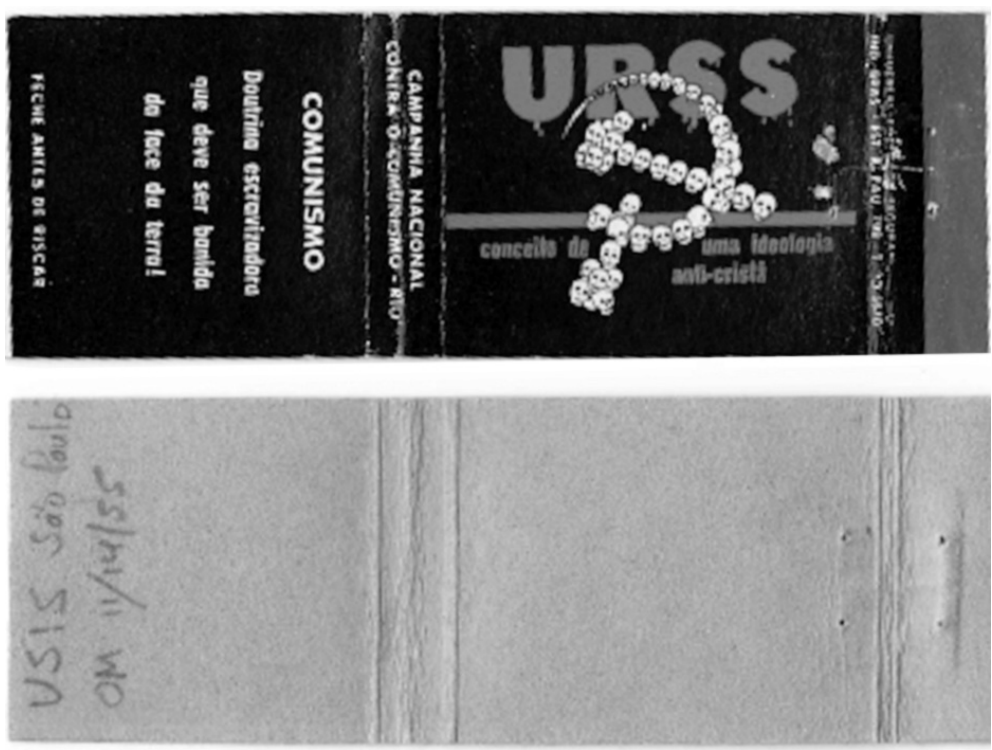

Figura 57 - Caixa de fósforos anticomunista produzida pela USIA no Brasil. No verso escrito à lápis “USIS São Paulo, OM 11/14/55”.

que êstes mesmos comunistas agora alegam ser discípulos de Vargas e tentam, no seu nome, agitar o país":

A mesma "Cruzada Brasileira Anti-Comunista", cujo símbolo era uma cruz, convocava os cidadãos a se engajar em um movimento comum de 20 países da América Latina, que reuniria delegados no segundo Congresso contra a intervenção soviética na América Latina, no Rio de Janeiro, de 22 a 25 de agosto de 1955.

No panfleto, a "garra" soviética proveniente do leste tinha dedos que representavam a imprensa comunista, o partido comunista, os comitês da paz, a "emancipação" e o CTAL (Comitê de Trabalhadores da América Latina).

Com as mesmas indicações de outros materiais dos arquivos de imprensa da USIA, o panfleto da "Cruzada Brasileira Anti-Comunista”, apresentava o verso com a mesma anotação a lápis, que indicava o local e a data do material: "USIS São Paolo OM 8/26/55". 


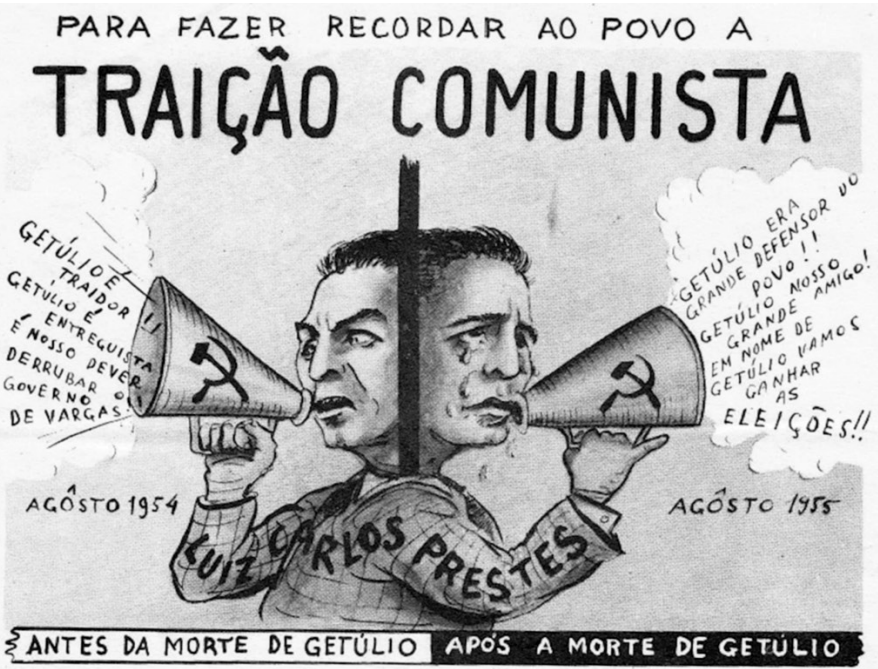

O PROGRAMA DOS COMUNISTAS (A LINHA FUNDAMENTAL DO PARTIDO COMUNISTA O BRASIL) DISSE DE GETÚllo VARGAS

"O govèrno de Vargas é, portanto, um govèrno de preparaçắo de guerra e de traiçáo naclonal. é um govêrno inimigo do povo... Nestas condiçoes, a luta irreconcillável e revolucionária de todos os patriotas brasileiros é indispensável para derrotar o govêrno de Vargas".

"Imprens? Popular", 10 de Janeiro de 1954

o comite central do partido comunista do BRasil disse de getúlio vargas : "Os fatos revelaram que valiam as promessas de Vargas - mentira, engôdo e mistificaçấo... Durante o govêrno de Vargas tudo plorou para o povo... No govêrno de Vargas deram-se os mais vergonhosos assaltos ao Tesouro Nacinal e à bôlsa do povo... O govêrno de Vargas já prendeu, espancou e torturou a milhares de patriotas e democratas"

"Imprensa Popular", 15 de Agōsto de 1954 APENAS DOIS DIAS ANTES DO SUICIDIO DO PRESIDENTE VARGAS, LUIZ CARLOS
PRESTES DISSE DE GETÚLIO VARGAS:

"Os trabalhadores brasileiros há muito conhecem os instintos sanguináríos do sr. Vargas e de seus policiais... Cresce o desprestigio e a impopularidade do sr. Vargas e, em número cada vez maior, os patriotas e democratas comecam a compreender que o atual estado de coisas náo pode continuar e que, como afirmam os comunistas, precisamos unir e organizar nossas fórças para pôr abaixo o govèrno de Vargas".

"Imprensa Popular", 22 de Agôsto de 1954

REPAREM NO CINISMO COM QUE ESTES MESMOS COMUNISTAS AgORA ALEGAM SER DISCFPULOS DE VARGAS E TENTAM, NO SEU NOME, AGITAR O PAIS.

Agora, sob o nome de "M.N.P.T.", o Partido Comunista quer aproveitar-se da memória de Getúlio Vargas, para ganhar as ele1cões e infiltrar-se no govêrno. O primeiro passo foi dađo enı Sấo Paulo, no dia 7 de Agôsto de 1955. A Cruzada Brasileira AntiComunista enviou ao Ministério da Justiça um processo contra o "M.N.P.T.", provando ser êste movimento agitador, o próprio "P.C.B." disfarçado. URGE, AGORA, FAZER CUMPRIR AS LEIS NACIONAIS.

\section{ABAIXO COM O M.N.P.T}

AJUDEM À SUA CRUZADA. DIRIJAM-SE À CX, POSTAL 910 RIO DE -IANEIRO

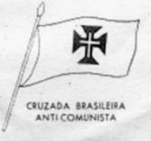

Figura 58 - Panfleto produzido pela USIA no Brasil após a morte de Getúlio Vargas, assinado pela "Cruzada Brasileira Anti-Comunista”, em 1955. 


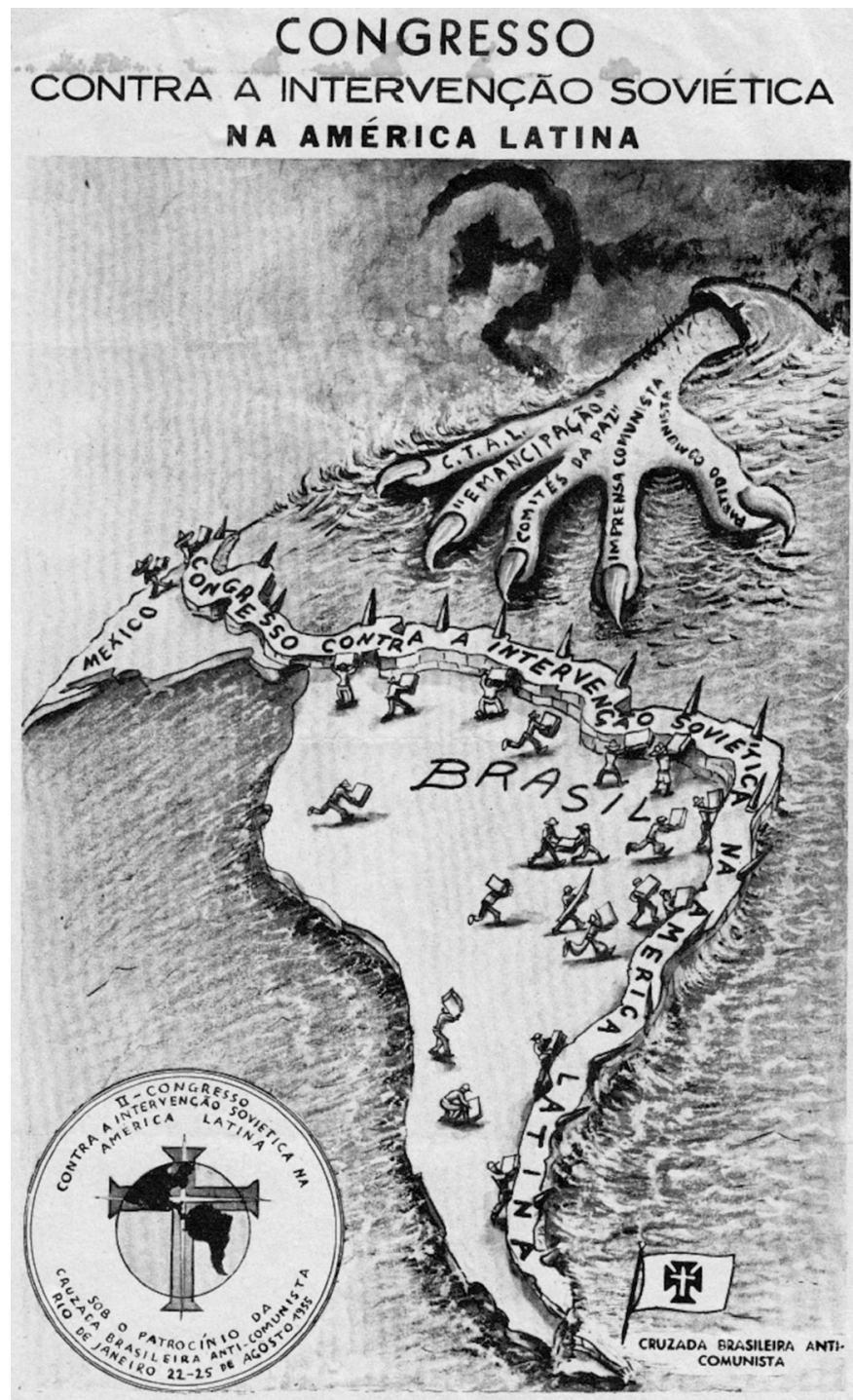

ESTE CONGRESSO REALIZAR-SE-A NO RIO DE JANEIRO DE 23 A DE AGOSTO DE 1955 COM A PARTICIPAÇÁO DE DELEGADOS EMINENTES DE VINTE PAISES DÉSTE HEMISFÉRIO AJUDEM A SUA CRUZADA. DIRIJAM-SE A CAIXA POSTAL 5394 - RIO DE JANEIRO

Figura 59 - Panfleto produzido pela USIA no Brasil convocando os brasileiros para o segundo Congresso contra a intervenção soviética na América Latina, com assinatura da "Cruzada Brasileira Anti-Comunista", em 1955. 


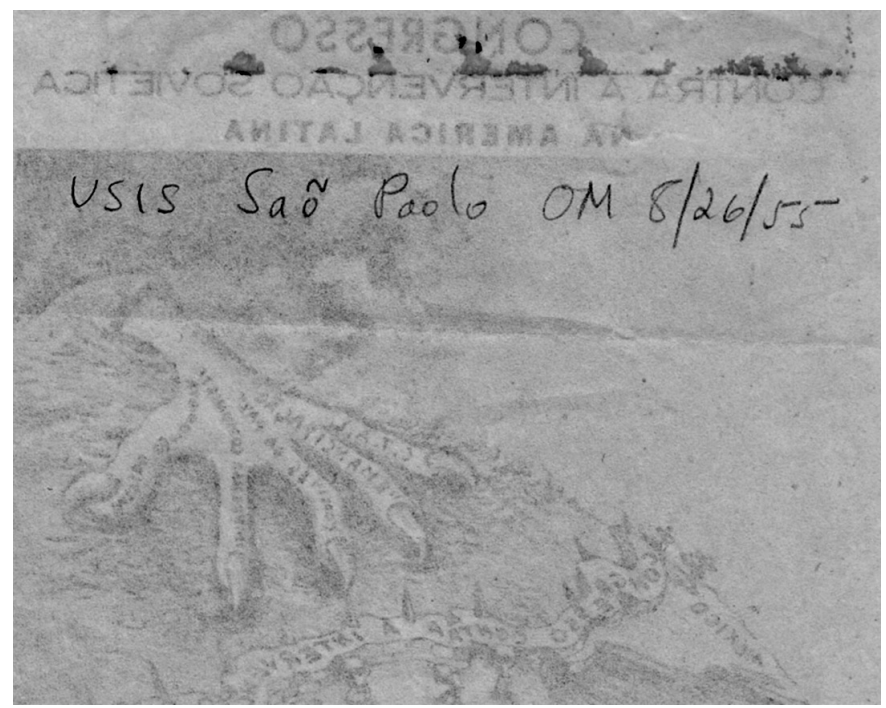

Figura 59 - verso

A "Cruzada Brasileira Anti-Comunista" assinava os materiais da USIA para a juventude e trabalhadores nos mesmos jornais que normalmente publicavam notícias e fotos (sem citar a fonte) da USIA. Foi o caso do material que alertava os estudantes (e suas famílias) sobre o Festival Mundial da Juventude, em 1955, que seria uma iniciativa comunista.

O documento abaixo teria sido ao menos encaminhado aos jornais: "Correio Paulistano", "O Dia", "Diário Com \& Ind.", "Diário de S. Paulo", "Diário da Noite", "O Estado de S. Paulo", "Folha da Manhã" (destacada com caneta vermelha), "Folha da Tarde", "Folha da Noite", "Gazeta", "O Tempo", Última Hora, "Times of Brazil" e "Notícias de Hoje".

Segundo o panfleto, um dos organizadores do Festival no Brasil seria o deputado Frota Moreira, que receberia ordens diretas dos russos. O mesmo teria visitado Moscou em janeiro de 1955.

A "Cruzada Brasileira Anti-Comunista" da USIA também criticava duramente o Judiciário brasileiro, que estaria sendo manipulado por forças comunistas brasileiras. Na ilustração, os juízes que 


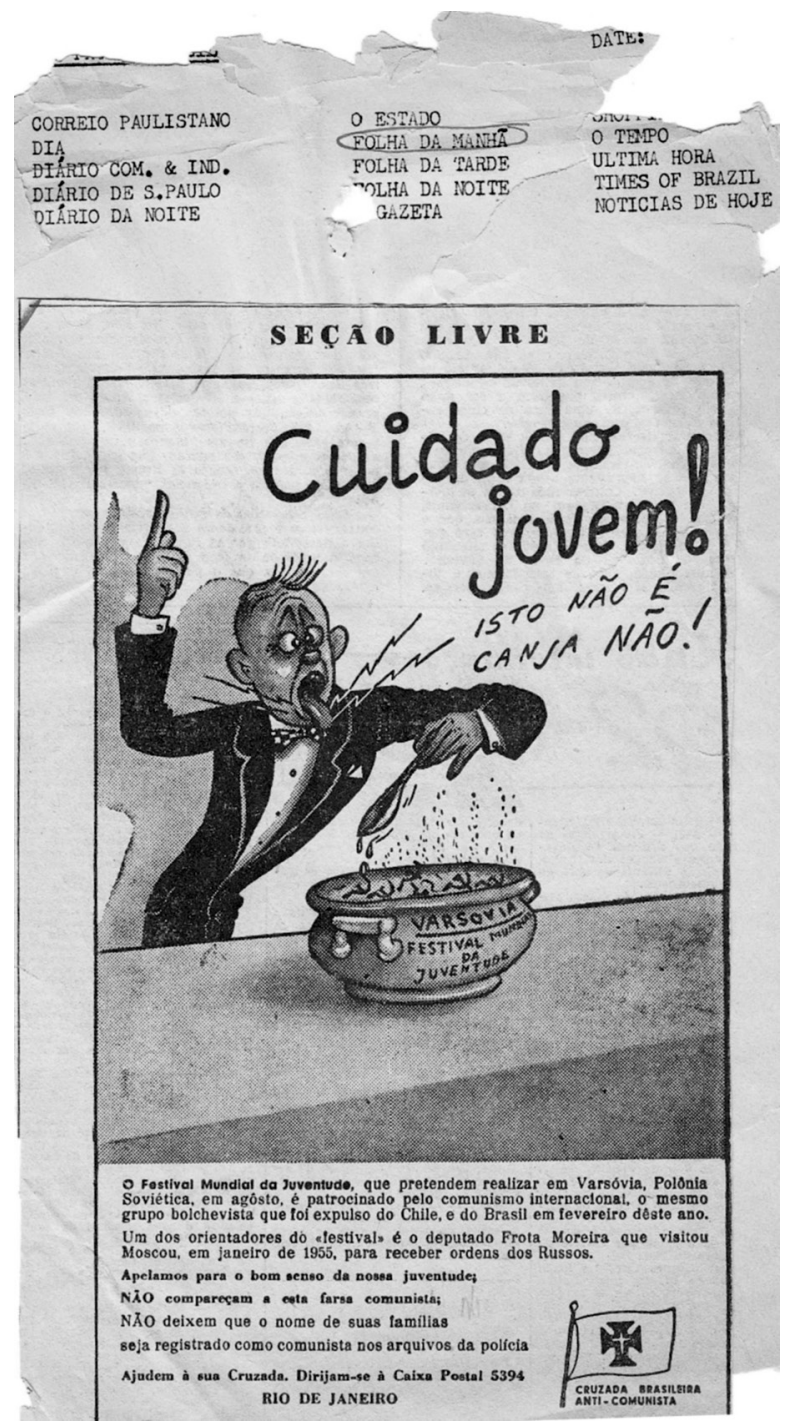

Figura 60 - Material da "Cruzada Brasileira Anti-Comunista", da USIA, em 1955, denunciando o Festival Mundial da Juventude como iniciativa comunista e apelando, nos grandes jornais do Brasil, para que os jovens não participem da atividade: "Não deixem que o nome de suas famílias seja registrado como comunista nos arquivos da polícia". 
seriam comunistas são citados e aparecem dilapidando as estruturas do Supremo Tribunal Federal a mando de Jorge Amado, escritor comunista baiano que, deitado em uma rede com um leque na mão, conversava com um pássaro preto, representante do Partido Comunista Brasileiro. Entre as campanhas "soviéticas" que ameaçavam as instituições brasileiras estavam a da "Paz" e a do "Petróleo".

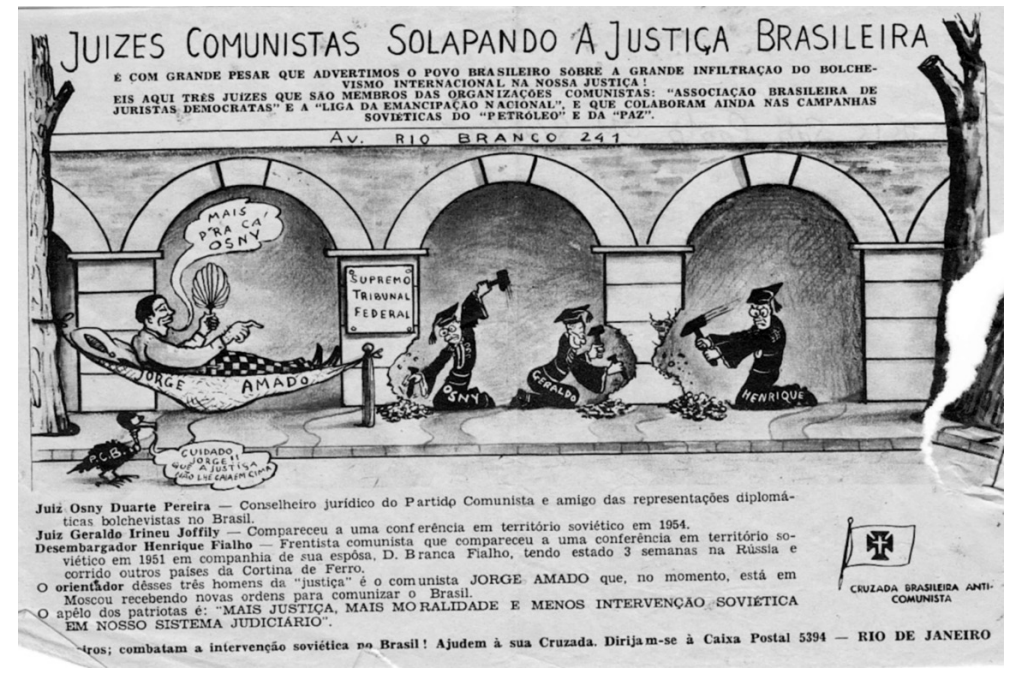

Figura 61 - Folheto da USIA, assinado pela "Cruzada Brasileira Anti-Comunista", denunciando a infiltração comunista no Judiciário. Todos os citados seriam orientados por Jorge Amado, sentado em sua rede com um leque. No verso do material, anotado "USIS São Paulo".

A USIA continuou utilizando-se da "Cruzada Brasileira Anti-Comunista” para fazer sua campanha, principalmente para os públicos estudantis e entre trabalhadores urbanos. Em 1956, por exemplo, divulgava uma revista ilustrada no suplemento "Singra", do jornal Correio da Manhã, que entre outras coisas, comparava Luiz Carlos Prestes a um "boneco de engonço", marionete brasileira manipulada pelos soviéticos. 


\section{AOS BRASILEIROS PATRIUIAD}

Năo se deixem liludir pelo novo embuste comunista representado pela chamada "Convenção pela Emancipaçáo Nacional". Tal "Convençáo" fol imaginada pelos bolchevistas da Rússla soviética e está sendo convocada, parz 15 de Abril proximo, pelos brasileiros traidores que cumprem ordens do embrutecido Malenkov! Nấo compareçam, nem tomem parte, nessa "Convençáo". Năo sấo os próprios

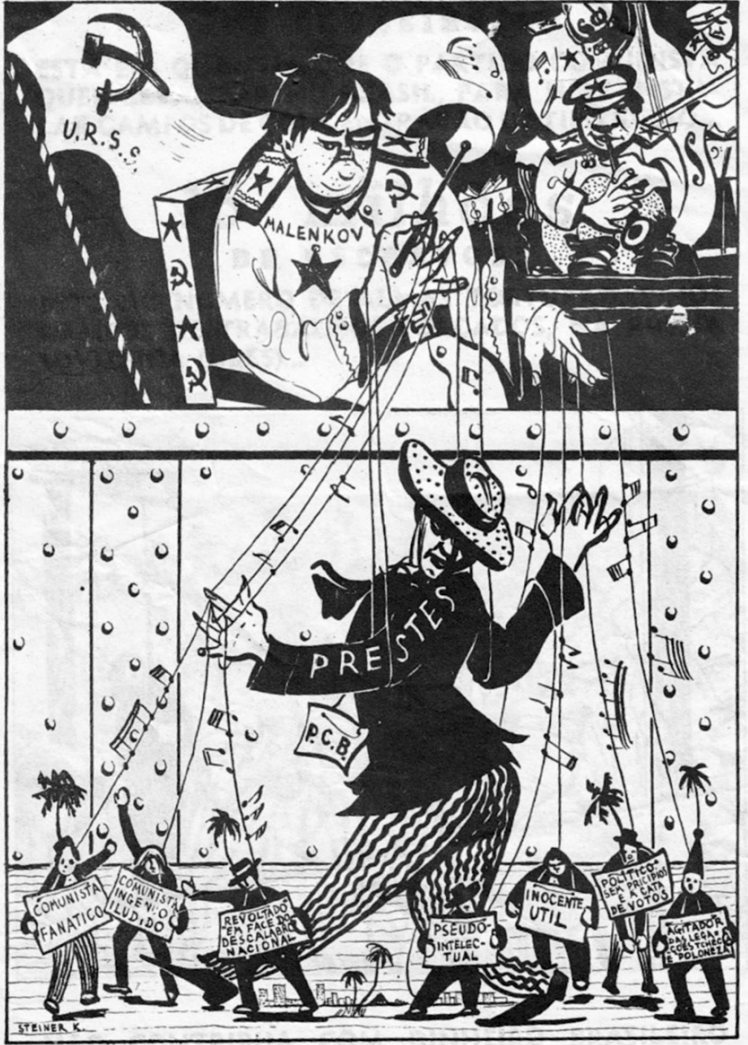

\section{MALENKOV MOVIMENTA SEUS BONECOS DE ENGONÇO}

Cruzada Brasileira Anti-Comunista (C.B.A.C.)

Figura 62 - Material da USIA, assinado pela Cruzada Brasileira Anti-Comunista, que mostrava Prestes como marionete dos soviéticos. Publicado no suplemento "Singra", no jornal Correio da Manhã, em 1956.

Além dos panfletos, a USIA também produzia séries de histórias em quadrinhos, muitas vezes traduzidas de produções para trabalhadores de outros países, como a "Comunistas contra o proletariado". Provavelmente uma publicação internacional da USIA, 
ela registrava em sua capa: "Enclosure No. 3 to São Paulo Despatch No. 113, dated November 19, 1953”. E abaixo estava o carimbo do Consulado Americano em São Paulo.

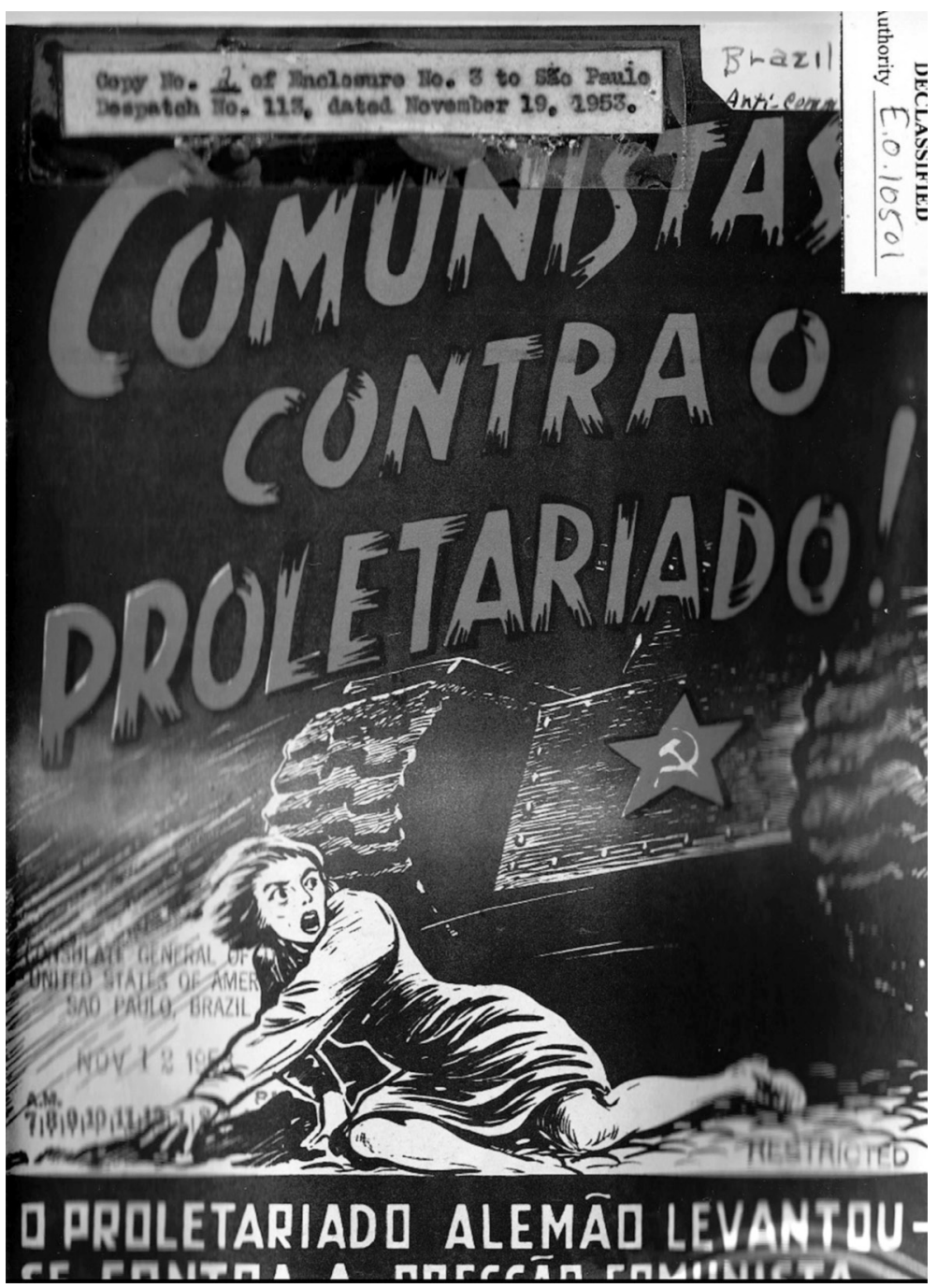

Figura 63 - Quadrinhos produzidos pela USIA para o Brasil, sem assinatura, que mostravam as revoltas dos operários alemães contra a opressão comunista naquele país, em 1955. 
A história, que não apresentava nenhuma assinatura de produção, contava a resistência do operariado alemão contra o regime comunista naquele país. As manifestações populares queriam livres eleições e o fim das leis trabalhistas ditadas pela União Soviética. $\mathrm{O}$ quadrinho contava a épica revolta, que destruiu as "luxuosas sedes do partido comunista" e expulsou, momentaneamente, os políticos soviéticos daquela região.

A história em quadrinhos contava a história do violento contra-ataque comunista, comandado pela Ministra da Justiça conhecida como "Hilda Vermelha", quando milhares de pessoas teriam sido massacradas e instituída a ditadura comunista na Alemanha.
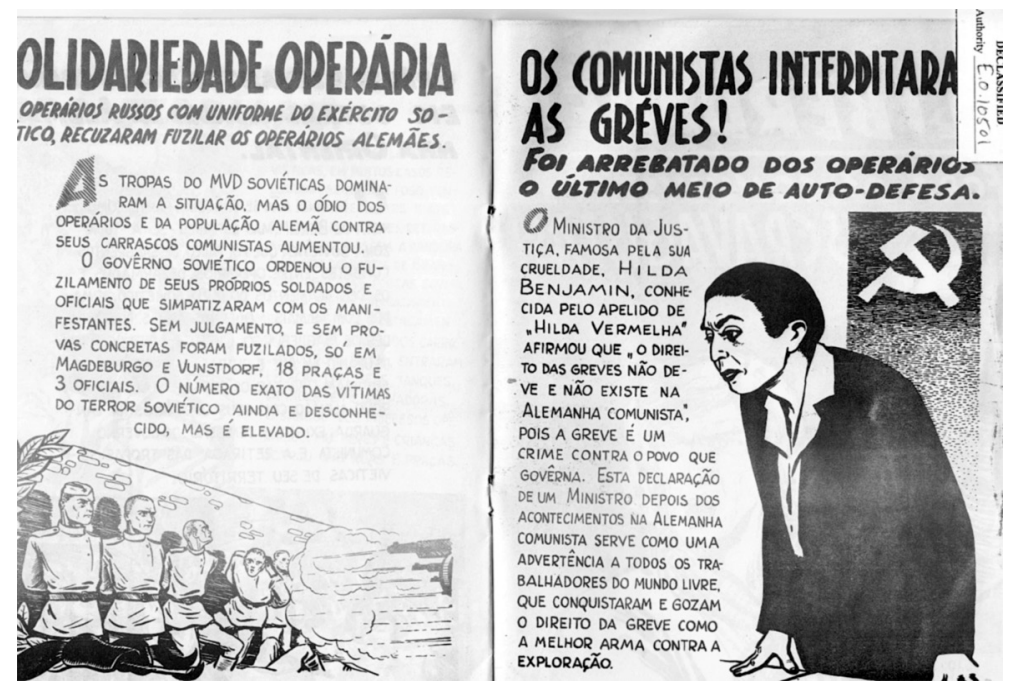

Figura 64 - Quadrinhos produzidos pela USIA para o Brasil, sem assinatura, mostrando a falta de liberdade laboral na Alemanha Comunista, em 1955.

Outra história em quadrinhos produzida pela USIA especificamente para operários brasileiros era uma série chamada "Zé Curioso”, de 1953, assinada pela Associação Democrática Cristã, de São Paulo. Os quadrinhos contavam a saga de um operário brasileiro que, por causa da propaganda comunista em sua fábrica, queria conhecer a realidade russa pessoalmente e, para isso, foi à embaixada 
soviética em Montevidéu, de onde poderia conseguir o visto para viajar à Moscou.

Chegando na Rússia, Zé Curioso é recebido por funcionários do partido comunista que o levam aos lugares turísticos e o hospedam em um luxuoso hotel. Sempre acompanhado de algum funcionário do governo comunista, ele é levado a visitar algumas fábricas-modelo, com funcionários felizes, bem alimentados e trajados.
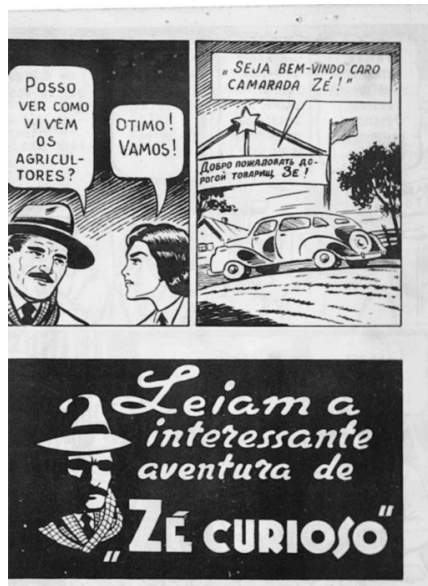

A.D.C. -1953 .
C:P. 3484. SÃO PAULO-BRAS

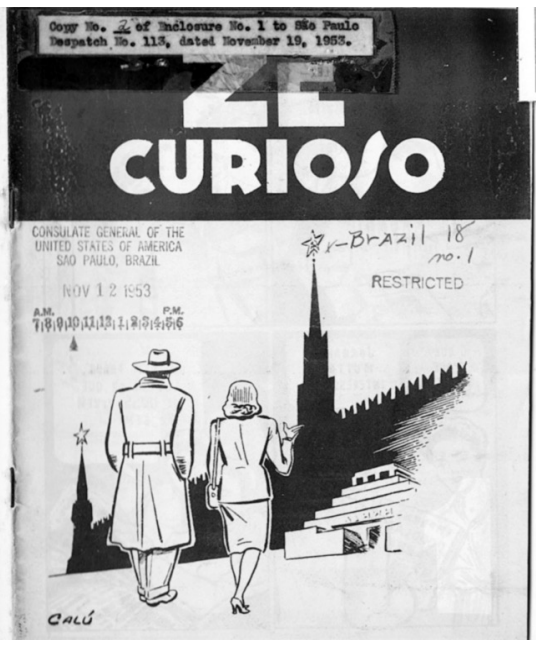

Figura 65 - "Zé Curioso", série de quadrinhos produzidos pela USIA no Brasil e assinados pela "Associação Democrática Cristã”, em 1953.

A série de quadrinhos mostrava a permanência de Zé Curioso na URSS, por sua própria vontade. A partir daí, seu passaporte é confiscado e ele começava a conhecer a verdadeira realidade soviética contada pela USIA, com precariedade nos transportes, falta de liberdade e de condições de trabalho. Por se revoltar contra o sistema soviético de trabalho, Zé Curioso é torturado e acaba em um campo de trabalho forçado na zona rural.

Por mandar cartas reclamando da URSS para sua mulher, interceptadas pelo serviço de espionagem soviético, Zé Curioso acaba sendo preso como espião americano e é forçado a confessar-se como espião. 
Os quadrinhos abordavam muitos dos temas do Brasil dos anos 1950, como acusações de infiltrações comunistas na Imprensa, no Governo, nos Sindicatos e no Judiciário. Além disso, toca também em temas como a nacionalização do petróleo brasileiro, que seria uma estratégia comunista para prejudicar os americanos e a liberdade brasileira.
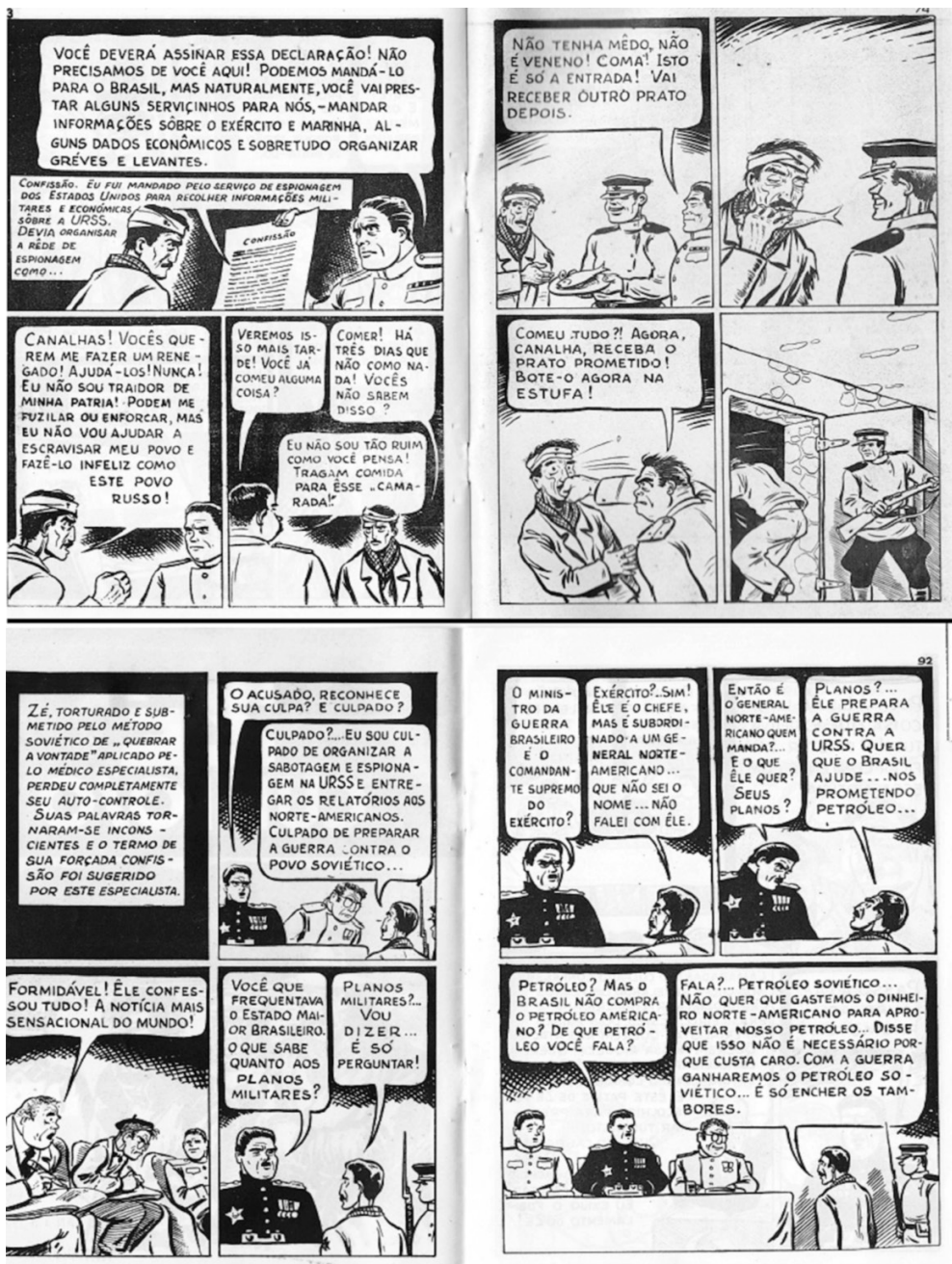

Figura 66 - "Zé Curioso”, quadrinho produzido pela USIA no Brasil, em 1954. 
É interessante notar que tanto o "Comunistas contra o proletariado", sem assinatura, quanto "Zé Curioso", produzido pela A.D.C, de São Paulo, são assinados pelo mesmo cartunista: Calú.

Os quadrinhos anticomunistas destinados a estudantes e trabalhadores brasileiros produzidos pela USIA apresentavam-se muitas vezes como apócrifos ou assinados por associações de existência duvidosa, como a "Cruzada Brasileira Anti-Comunista", ${ }^{178}$ ou "Associação Democrática Cristã”. No material encontrado nos arquivos da USIA no Brasil, muitos deles eram indicados como atribuídos a essas organizações, como esse abaixo atribuído à A.D.C., de 1952 .

Em outras ocasiões, alguns trabalhos distribuídos pela USIA eram assinados por organizações internacionais do trabalho anticomunistas ligadas a associações americanas de trabalho, como a Organização Regional Interamericana de Trabalhadores (ORIT), como o caso do panfleto "Ameaça ao Trabalhador", localizado nos arquivos americanos entre os materiais produzidos pela USIS no Rio de Janeiro, em 1956.

Segundo a publicação assinada pela ORIT em 1956, essa organização tinha sido criada para fazer frente à Confederação dos Trabalhadores da América Latina (CTAL), que sofreria a infiltração comunista e ameaçava a liberdade sindical dos trabalhadores latino-americanos. $\mathrm{O}$ folheto, cheio de elogios a líderes sindicais norte-americanos que representavam a Federação Americana do Trabalho (AFL) e o Congresso das Organizações Industriais (CIO), criticava duramente a infiltração comunista estrangeira no continente americano e apresentava a Organização Regional Inter-americana do Trabalho como saída para a liberdade dos trabalhadores das Américas: "As associações de classe das Américas têm revelado sua capacidade em repelir e destruir a ameaça comunista, especialmente

178 A Cruzada Brasileira Anti-Comunista, ligada a "Confederação Inter-Americana de defesa do continente era comandada pelo Almirante Carlos Penna Botto nos anos 1950, e tinha como principal atividade a publicação de materiais anti-comunistas pela imprensa (Abreu Penna, 2008). Os arquivos históricos americanos mostram, no entanto, que esses materiais eram produzidos pela USIA em Washington DC e distribuídos pelos USIS no Brasil. 


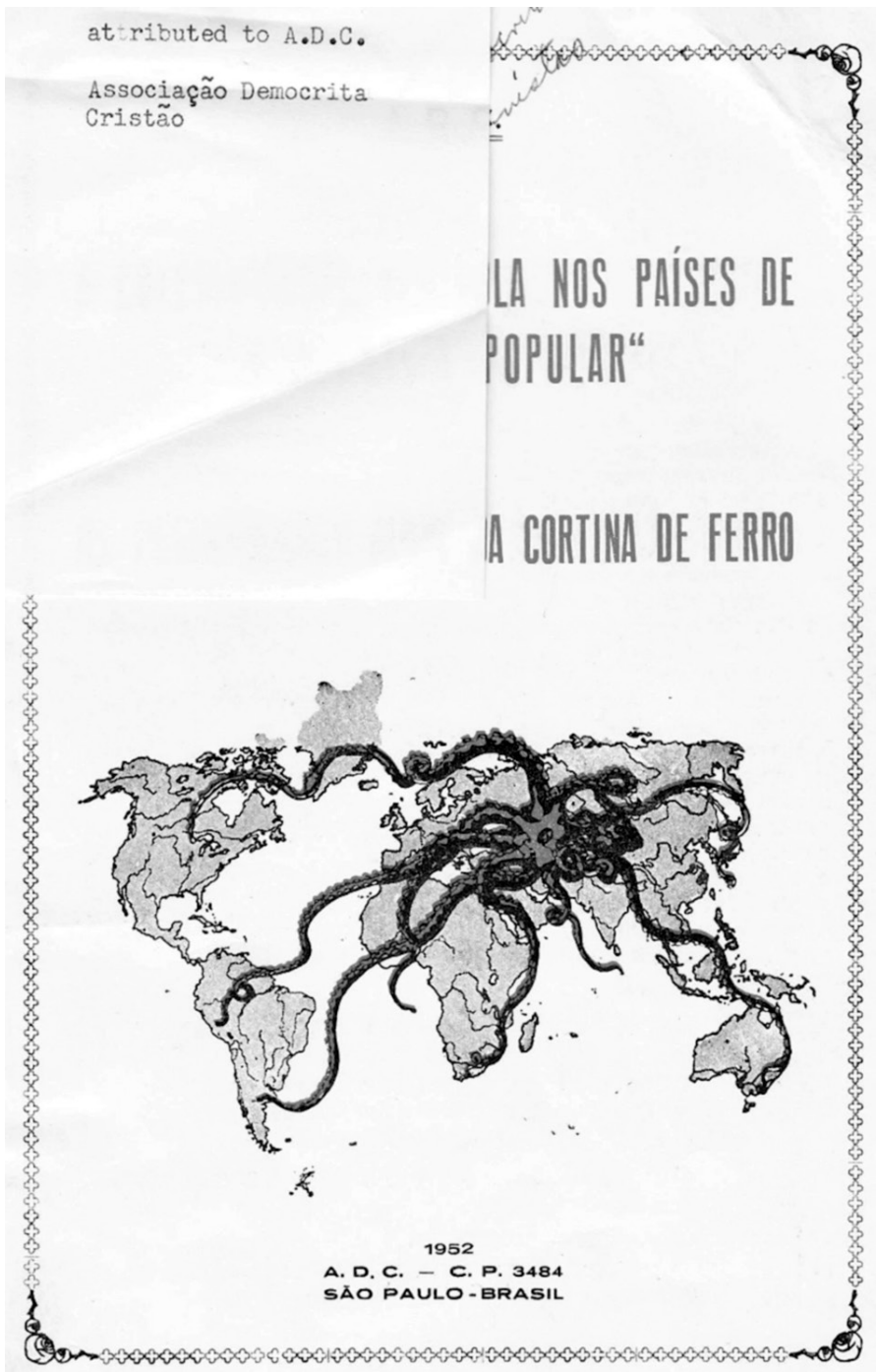

Figura 67 - Material anticomunista do USIS em São Paulo, "attributed to A.D.C., Associação Democrita Cristão [sic]”, em 1952. 


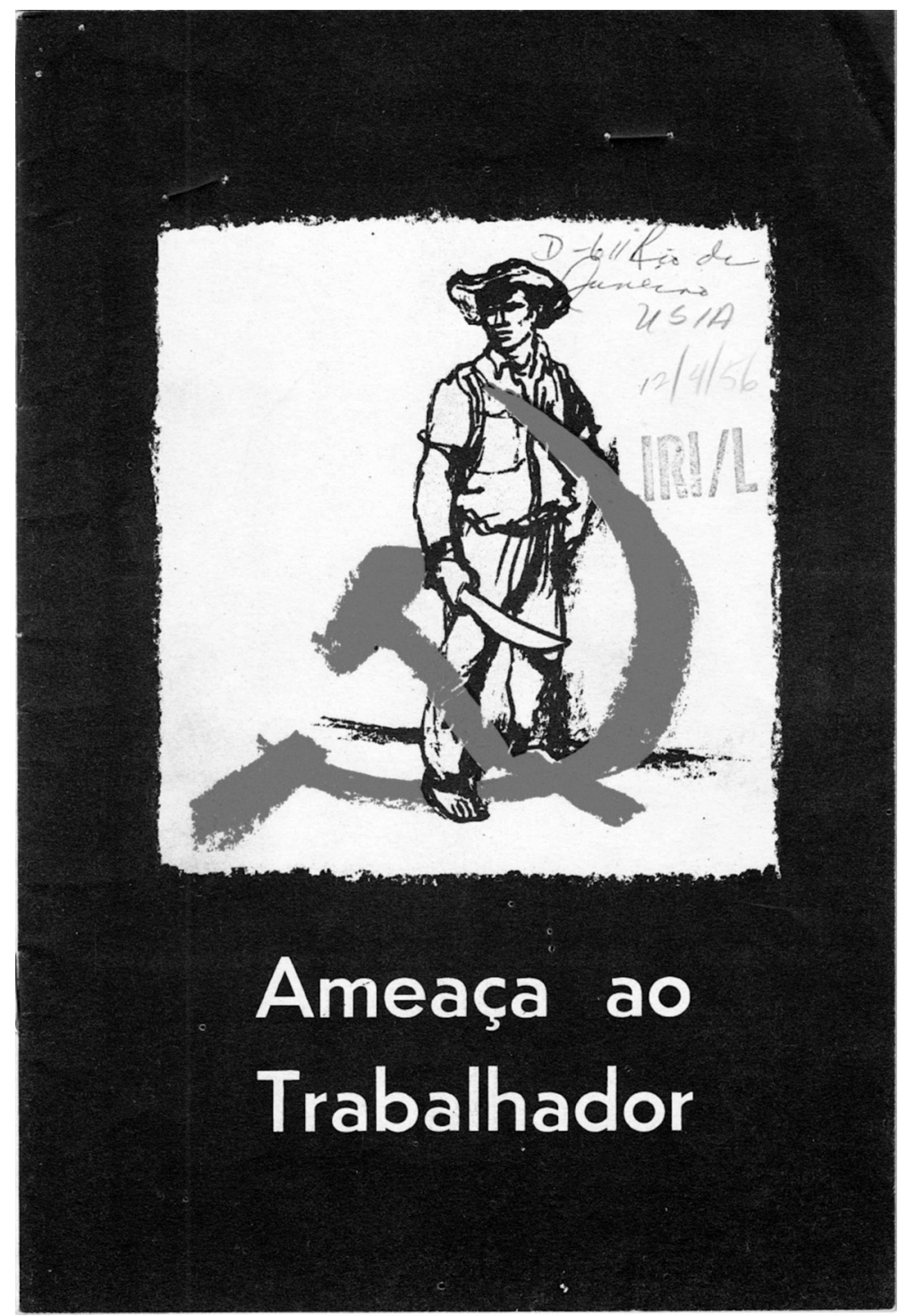

Figura 68 - Material do USIS no Rio de Janeiro, atribuído à recém-criada ORIT, em 1956. 
a partir de 1949, quando criaram a Confederação Internacional dos Sindicatos Livres e, pouco depois, a Organização Regional Inter-americana do Trabalho (ORIT)".

A última página do material era assinada pela ORIT, com endereço do escritório da organização em São Paulo, na Rua dos Andradas, 96. Em cima, a lápis, era indicada a cidade do Rio de Janeiro, que também tinha sido apontada na capa do encarte, o USIS/Rio, com carimbo do Consulado Americano. No final, era classificado como "anti-communist".

$$
\text { Ris de } 10 \text { (anti-communist) }
$$

ESCRITÓRIO NO BRASIL DA ORIT E CIOSL

RUA DOS ANDRADAS. $96-50^{\circ}$ AND.

\section{REPRESENTANTE : Joviano de Araujo}

Figura 69 - Material anticomunista assinado pela ORIT, mas produzido pelo USIS no Rio de Janeiro, em 1956.

Após a Revolução cubana, crescia a atenção dada aos movimentos potencialmente revolucionários comunistas na América Latina. Cada vez mais, aos olhos da USIA, além de estudantes e operários, grupos como as Ligas Camponesas, no Nordeste brasileiro, à medida que se fortaleciam, tornavam-se prioritários para a agência.

De acordo com relatório da USIA sobre um seminário promovido pela União Nacional de Estudantes para discutir os problemas do Nordeste, realizado em novembro de 1962, em Campina Grande/ Paraíba, observa-se que grupos de esquerda presentes na atividade - Ligas Camponesas, estudantes e sindicatos - se organizavam e fortaleciam. ${ }^{179}$

179 Documento 108: "Student program: UNE-Sponsored Seminar on Norheast Problems". 
Entre os grupos destacados pelo relatório do USIS/RJ, enviado à sede da USIA em Washington D.C., estava o Movimento Revolucionário Tiradentes (MRT), comandado por Francisco Julião, que com estudantes, sindicalistas e apoio do Partido Comunista Brasileiro, distribuiria armas a seus integrantes no Nordeste. O segundo grupo destacado era o próprio Partido Comunista Brasileiro, que aproximaria lideranças estudantis regionais, como Conceição Sarney (UNE/Maranhão) e José Carlos Capinam (UNE-Bahia) das Ligas Camponesas. O terceiro grupo a ser observado pela USIA era a Política Operária (POLOP), com inspiração no comunismo chinês e maior penetração nos grandes centros urbanos. O último era a Juventude Universitária Católica (JUC), com grande participação dos estudantes do Nordeste e da ala mais à esquerda da igreja. ${ }^{180}$

Considerando essas movimentações políticas, em abril de 1963, a USIA propôs ao Departamento de Estado a reavaliação do programa de bolsas de estudos aos latino-americanos aos EUA, para que fossem mais voltadas para o treinamento de lideranças, nos próprios países, para o combate ao anticomunismo:

muitos dos líderes revolucionários antiamericanos da América Latina visitaram ou estudaram nos Estados Unidos. Os projetos da USAID são propositalmente planejados para utilizar e mobilizar jovens lideranças e envolvê-los em trabalhos construtivos [...] mas utilizar treinamento profissional de mais jovens graduados universitários faria muito mais do que trazê-los aos EUA. Eles se convencerão mais tendo um papel no progresso de seu próprio país. ${ }^{181}$

A agência ainda recomendava que o foco dos estudantes bolsistas mudasse, privilegiando os intelectuais, artistas, com perfil de ciências humanas - mais do que os técnicos e militares - pois

180 Documento 108: "Student program: UNE-Sponsored Seminar on Norheast Problems".

181 Documento 108: "Student program: UNE-Sponsored Seminar on Norheast Problems". 
apresentavam perfil mais "subversivo", de acordo com os revolucionários cubanos:

Os projetos destacados são de natureza muito mais militar e técnica. Em Cuba, as jovens pessoas que lideraram a Revolução e assumiram posições de destaque no regime de Castro eram, em sua maior parte, advogados, estudantes de artes liberais, artistas e escritores, etc. Esses jovens intelectuais geralmente desempenham um papel mais ativo na arena política do que jovens oficiais das Forças Armadas e engenheiros. ${ }^{182}$

Em 1963, o Nordeste brasileiro virou uma região crucial na avaliação do governo americano ${ }^{183}$ que traçava, por meio de pesquisa patrocinada conjuntamente pela USIA e USAID, ${ }^{184}$ um perfil do nordestino médio: analfabeto, pobre e isolado, mas que na sua maioria (2/3) estava satisfeito com suas condições de vida: "A maioria dos camponeses do Nordeste ainda são, na sua grande maioria, ignorantes ou indiferentes às ideias sobre modernização ou revolução política. Eles têm pouca consciência social”. ${ }^{185}$

Entre os nordestinos entrevistados, 73\% de áreas rurais e 27\% de cidades pequenas, os programas de ajuda e cooperação norte-americana na região eram muito pouco conhecidos, como a "Aliança para o Progresso", conhecida somente por $15 \%$ da população da região. $\mathrm{O}$ programa "Food for Peace", era conhecido somente por 4\%, apesar de $8 \%$ dos nordestinos saberem que estavam recebendo doações de alimentos vindas dos EUA. ${ }^{186}$

182 Documento 108.

183 Documento 109: "Agitation and Public Opinion in Crucial Areas of Northeast Brazil, 1963".

184 Documento 111: "Peasant Attitudes in Northeast Brazil, February 14, 1964".

185 Documento 111: "Peasant Attitudes in Northeast Brazil, February 14, 1964".

186 Documento 109: "Agitation and Public Opinion in Crucial Areas of Northeast Brazil, 1963". 


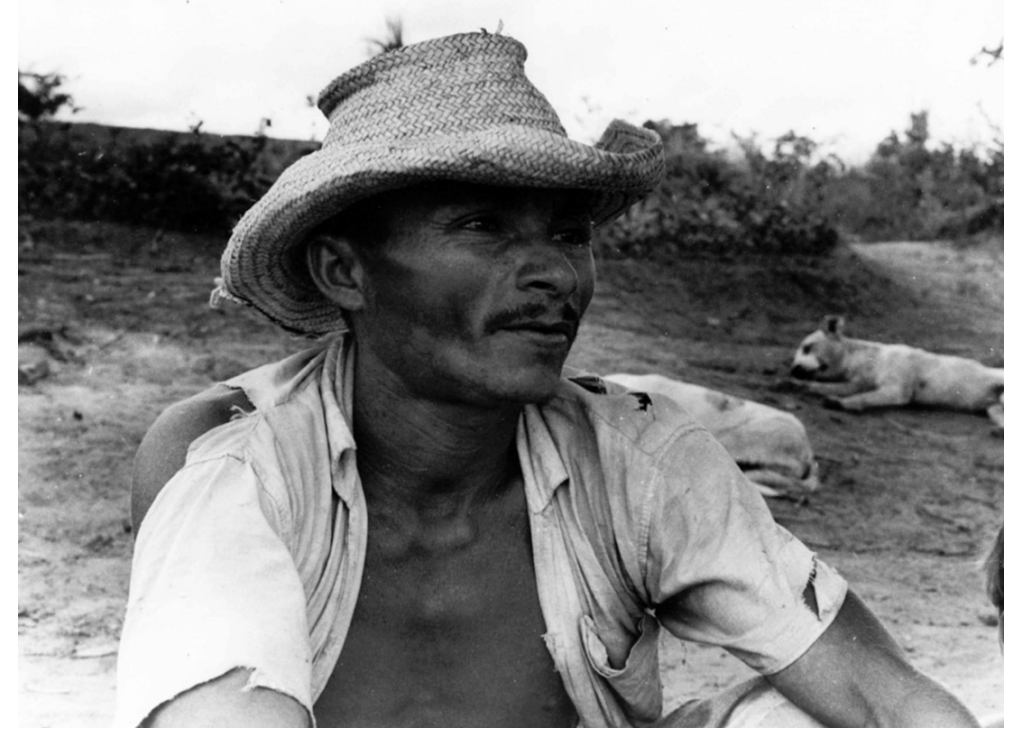

Figura 70 - Camponês nordestino participante de pesquisa patrocinada pela USIA e USAID sobre opiniões e atitudes de trabalhadores rurais do Nordeste Brasileiro, em 1963.

Foram analisados trabalhadores das cidades de Cabo, Vitória de Sto. Antão, Pesqueira, Aurora, Cabrobó, Sapé, São João do Cariri e Caiçara (do interior do Nordeste) e dos trabalhadores mais "qualificados" das usinas de açúcar de Pumaty, Cachoeira Lisa, Central Barreiros, Santa Terezinha, Santo Inácio e Matary (PE), das usinas de Santa Maria, São João e Tanques (PB). ${ }^{187}$

A pesquisa da USIA nesses locais apontava que $67 \%$ dos entrevistados nordestinos eram a favor da reforma agrária e 38\% desses defendiam as indenizações aos proprietários de terras. Apesar de conhecerem o nome "Ligas Camponesas", padre Melo (2\%) e Julião (1\%) eles eram pouco conhecidos, ao contrário do Presidente João Goulart e do governador de Pernambuco, Miguel Arraes, ambos conhecidos e bem avaliados pela grande maioria da região. Além dos

187 Documentos 81 e 111. 
nomes citados, também foi medida a avaliação de Fidel Castro, o único entre os pesquisados que foi mais mal avaliado do que bem. ${ }^{188}$

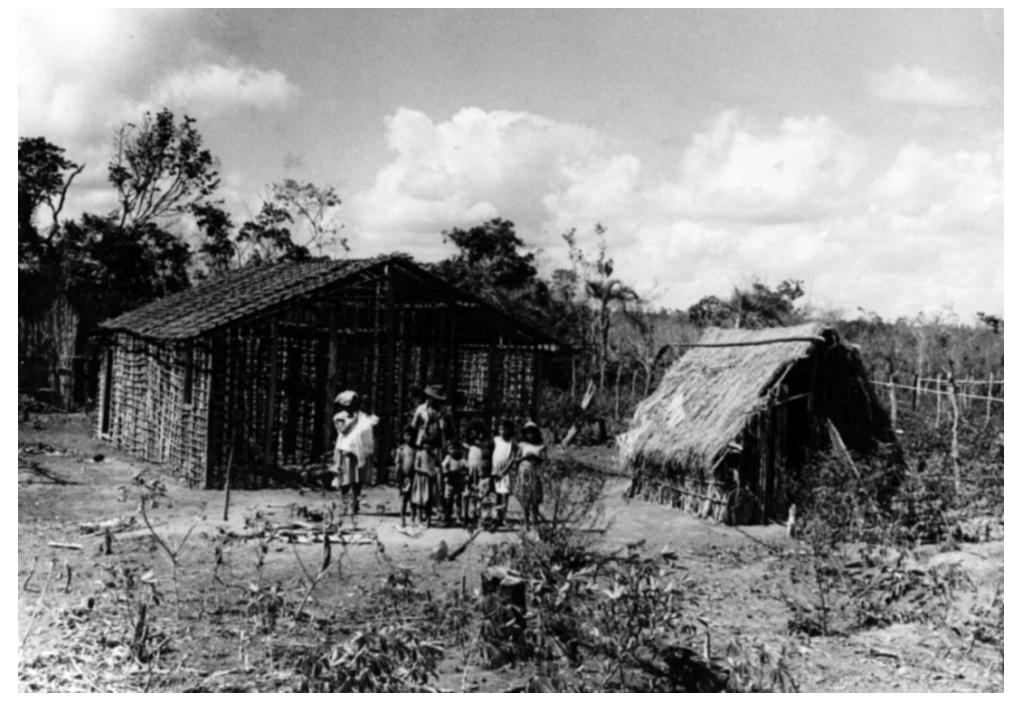

Figura 71 - Casa de camponeses nordestinos entrevistados em pesquisa da USIA e USAID, sobre o perfil dos trabalhadores rurais do Nordeste brasileiro, em 1963.

O levantamento da agência no Nordeste em 1963 ainda diagnosticava que a maior aceitação ao comunismo estava na parte litorânea da região: $11 \%$ desses achavam que o comunismo deveria ser mais forte do que era naquela ocasião. Mas, mesmo no litoral, onde os números comunistas se apresentavam maiores, $20 \%$ da população queria que o comunismo fosse menor do que era naquele momento. ${ }^{189}$

188 Documento 109: "Agitation and Public Opinion in Crucial Areas of Northeast Brazil, 1963".

189 Documento 109: "Agitation and Public Opinion in Crucial Areas of Northeast Brazil, 1963". 


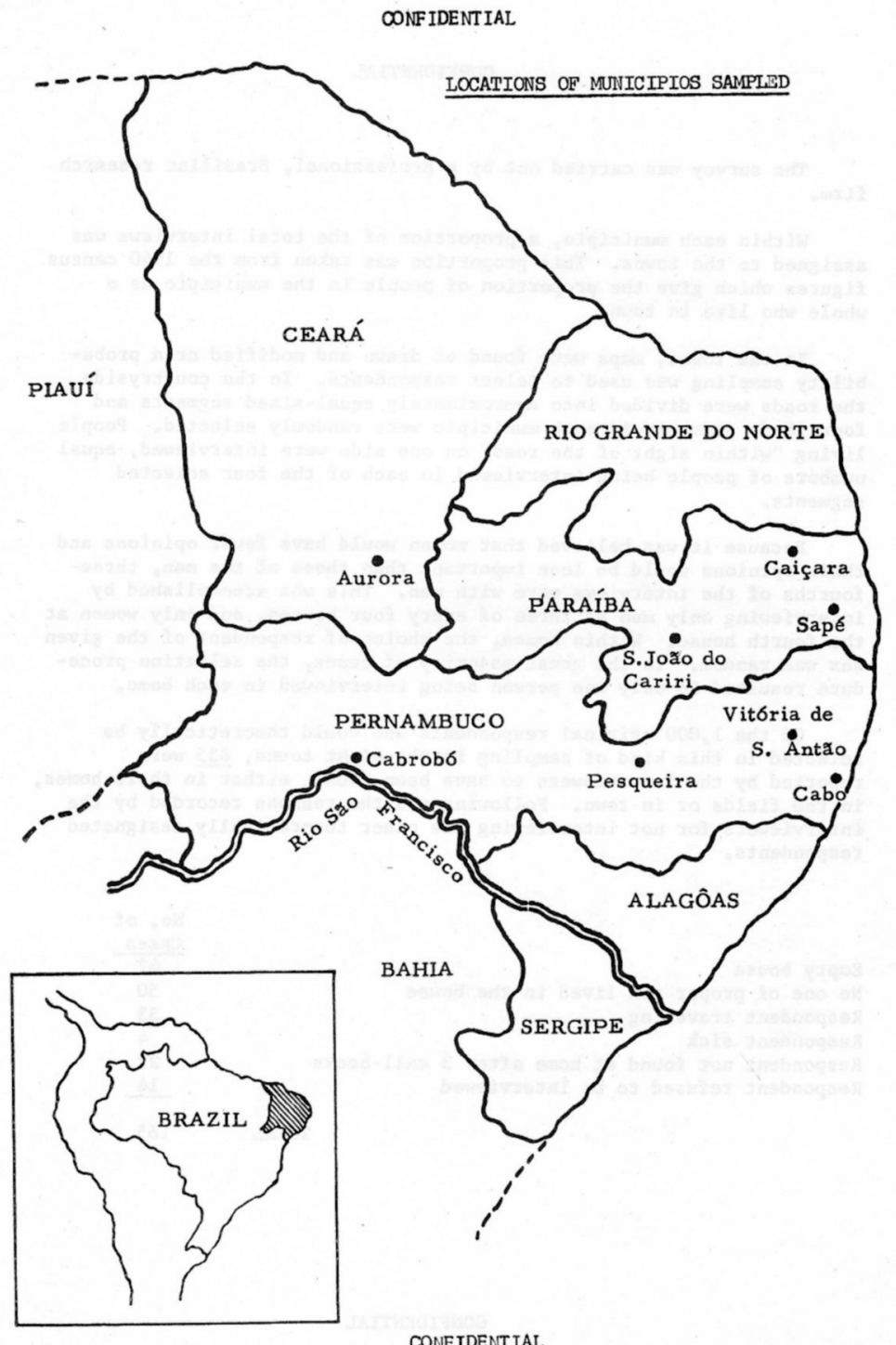

CONFIDENTIAL

Figura 72 - Municípios pesquisados pela USIA e USAID, sobre trabalhadores rurais do nordeste brasileiro, em 1963. 
O interesse da USIA e da USAID no Nordeste não era à toa. Segundo Bandeira, ${ }^{190}$ em seu clássico "Presença dos Estados Unidos no Brasil", desde o final dos anos 1950 o governo americano dedicou-se à ocupação clandestina do nordeste brasileiro, disfarçada de grupos de cooperação (seja pelo "Aliança para o Progresso" ou "Peace Corps"), mas que se preparava para uma possível ocupação da área, potencialmente subversiva, como apontavam as pesquisas da USIA/USAID:

As verbas da Aliança para o Progresso, a fim de pretensamente promover certa melhoria (de caráter assistencial) nos padrões de vida da população nordestina, constituíram apenas um dos instrumentos com que os Estados Unidos jogaram, para conter ou esmagar qualquer revolução. ${ }^{191}$

Ainda, segundo Bandeira, a imigração americana para o Brasil foi maior no começo dos anos 1960 do que no período da 2a Guerra, quando os EUA tinham bases militares oficiais no País, conforme os números de pedidos de visto para americanos no Brasil, abaixo: ${ }^{192}$

\begin{tabular}{cc}
\hline Anos & $\begin{array}{c}\text { Entradas de norte- } \\
\text {-americanos }\end{array}$ \\
\hline 1958 & 1.905 \\
1959 & 1.462 \\
1960 & 1.184 \\
1961 & - \\
1962 & 4.968 \\
1963 & 2.463 \\
1964 & 764 \\
1965 & 979 \\
1966 & 823 \\
\hline
\end{tabular}

190 Bandeira (1973, p.354).

191 Bandeira (1973, p.354).

192 Idem. 
Os dados e diagnóstico apontados por Bandeira seguem coerentemente com o aumento do número de funcionários na América Latina até 1964, e os métodos indicados para atividades de "black propaganda" da USIA em áreas de "risco subversivo". Segundo Bogart (1995, p.121), em estudo interno sobre os métodos de propaganda americana a serem adotados no exterior em lugares prioritários, a agência deveria criar clandestinamente o seu próprio "agitprop":

Para combater o comunismo, a USIA deve usar algumas armas comunistas (infiltração, distribuição de materiais não-atribuídos). A USIA deve ter seu próprio aparato de "agitprop" (um neologismo soviético para especialistas em agitação e propaganda) para estimular discussões e espalhar a propaganda boca-a-boca. Ela deve instalar centros de treinamento de "agitprop" pró-americanos em países importantes. Em resumo, seria melhor para agência manter operações na superfície que se dedicassem a formar um "quadro completo e honesto", como um disfarce para outras atividades clandestinas.

\section{As exposições, turnês e as parcerias entre cidades}

Gershwin emocionou muito os moscovitas (com Porgy and Bess)

Bernstein era o queridinho do Brasil (e ele não é moderninho?)

E só para acabar a confusão interna

Nós despachamos a Martha Graham

É isso o que chamamos de intercâmbio cultural

Isso é o que chamamos de intercâmbio cultural

Música de Iola E David Brubeck cantada por Louis Armstrong no disco "The Real Ambassadors", de 1961. ${ }^{193}$

193 Música "Cultural Echange" (Letra de Iola e Dave Brubeck, Música de Dave Brubeck), do disco "The Real Ambassadors"(gravada originalmente em 19 de 
Além das ações locais com os centros binacionais e das atividades específicas para grupos prioritários, o Brasil também recebeu as políticas globais da USIA, como turnês artísticas, musicais, esportivas, exibições, feiras sobre temas de interesse da agência e o início do irmanamento entre cidades brasileiras e americanas.

A epígrafe do subcapítulo sintetiza de maneira brilhante a ideia do "intercâmbio cultural" norte-americano do qual participaram como protagonistas David Brubeck, Louis Armstrong, Dizzy Gilespie e muitos outros jazzistas, atores, dançarinos, musicistas e atletas americanos. A utilização das artes e dos esportes para mudar a imagem de país segregacionista e ampliar a ideia da vanguarda artística e esportista americana, foi promovida a todo vapor pelos governos de Eisenhower e Kennedy. E o Brasil fez parte disso, principalmente como receptor.

Em 1954, o país recebeu a turnê do grupo de dança José Limon. Em 1955, o Brasil já entrava no circuito internacional das turnês da USIA, com a pianista Philippa Schuyler, a violonista Joyce Flissler, o musical Porgy E Bess, ${ }^{194}$ os dançarinos Tallchief \& Eglevsky e o "American Ballet Theatre".

Além disso, em 1955, mesmo ano que o governador Jânio Quadros proibia o Festival Sul-Americano da Juventude (segundo a USIA, apoiado por Moscou) em São Paulo ${ }^{195}$, o Brasil começava a receber grupos esportivos enviados pelo governo americano, como as equipes de atletismo e natação da "Amatheur Athletic Union" (AAU), organização responsável pelos atletas olímpicos americanos de então. ${ }^{196}$

Em 1956, a USIA detectava o poder da música para modificar a imagem americana no exterior e recomendava o seu uso em todos os postos: "A agência acredita que um forte programa de música

Setembro de 1961). Gravadora Sony/Columbia, ASIN: B0000029FQ.

194 Sobre o uso político do Porgy E Bess no exterior, contando a história de amor de dois negros (ao som das melodias de Gershwin) e promovendo a ideia dos EUA como uma democracia racial, ver Saunders (2000); Von Eschen (2004).

195 Documento 115.

196 Documento 113. 
nos USIS é um meio importante para demonstrar a criatividade da América nas artes e isso pode desempenhar um papel significativo no programa cultural como um todo". ${ }^{197}$

No mesmo ano, o Brasil também começava a fazer parte das turnês teatrais como a peça "Teahouse of the August Moon", 198 além das musicais que continuaram como o "New York Woodwind Quintet" e uma das grande estrelas das turnês de jazz americanas patrocinadas pelo governo: o "Dizzy Gillespie Jazz Band”. Ainda em 1956, o Brasil recebeu o time de basquete universitário de São Francisco, o San Francisco Dons, que mostrava o esporte inventado na América do Norte, para o público brasileiro. ${ }^{199}$

Enquanto isso, os artistas e esportistas dos blocos comunistas também começaram a se apresentar no país em 1956, como com a companhia tcheca de dança típica "Lucnica" (com 50 integrantes), a Companhia de Ópera Peiping (com 90 integrantes), a seleção de futebol da Tchecoslováquia e a de basquete da URSS. ${ }^{200}$

Em 1957, ano das visitas do compositor soviético Katchaturian e da companhia de balé Bolshoi, as seleções de basquete feminino de URSS, Tchecoslováquia e Hungria também participaram do campeonato mundial de basquete feminino no Brasil, mas foram vencidas pela equipe campeã norte-americana. No mesmo ano, os EUA enviavam ao país o violinista Joseph Fuchs, a contralto Blanche Thebom, o coral masculino "Columbus Boychoir", a sinfonietta Zimbler (música de câmara) e o grupo de teatro da Universidade de Minnesota. ${ }^{201}$

197 Documento 114.

198 A peça não foi tão bem recebida pela crítica especializada local. Em reportagems no Correio da Manhã e no "Diário de Notícias", apesar de destacarem a boa atuação de Rosita Diaz Gimeno, a peça era vista como um "desperdício de dinheiro do Departamento de Estado, se a sua intenção era promover o teatro norte-americano", segundo relato de reportagem do jornal New York Times, de 7 de maio de 1956, segundo Documento 50: "1956: "Teahouse of August Moon" flops in Rio de Janeiro".

199 Documento 113.

200 Documento 113.

201 Documento 113. 
Enquanto a seleção de futebol búlgara jogava no Brasil em 1958, os EUA enviavam a Filarmônica de New York regida pelo maestro Leonard Bernstein. O concerto da Filarmônica com Bernstein no Rio de Janeiro, no ginásio do Maracanãzinho lotado com 15 mil pessoas, também contou com a presença do Presidente Juscelino Kubitschek. A orquestra tocou um vasto repertório, com músicas de Brahms, Gershwin, Tchaikovsky e até o hino brasileiro. No final, o maestro brasileiro Eleazar de Carvalho foi convidado para conduzir a Filarmônica de Nova York, tocando o hino americano "The Star-Spangled Banner".

A turnê de Bernstein fez tanto sucesso, que depois de alguns dias, na apresentação em São Paulo, a única gratuita do Brasil, o público pediu tantas músicas que a orquestra perdeu o vôo de volta aos EUA. Em seu retorno aos EUA, Bernstein foi recebido como herói em Nova York. ${ }^{202}$

Ainda em 1958, apresentaram-se no Brasil o quarteto de cordas Stanley, o grupo de teatro da Catholic University, o grupo de balé de São Francisco e a banda do jazzista Woody Herman. Em 1959, era a vez da Orquestra Sinfônica Nacional e da soprano Phyllis Curtin. ${ }^{203}$ No último ano de Eisenhower e nos anos Kennedy as turnês mundiais americanas continuaram a privilegiar o Brasil na sua rota.

Em 1960, o país recebeu o coral da Universidade de Howard, e mais uma vez a companhia de dança José Limon. Em 1961, quando a batida da Bossa Nova começava a despontar no mundo, foi a vez do violonista Charlie Byrd e seu trio, além da companhia teatral "American Repertory Company". ${ }^{204}$

Em 1962, o governo americano enviou a companhia de teatro da Universidade de Cornell, o sexteto de jazz de Paul Winter, o trio vocal Chad Mitchell e a seleção de basquete da AAU. ${ }^{205}$

Os programas mundiais da USIA também incluíam diversas feiras e exposições que faziam turnês mundiais das principais marcas

202 Documento 116.

203 Documento 113.

204 Documento 113.

205 Documento 113. 


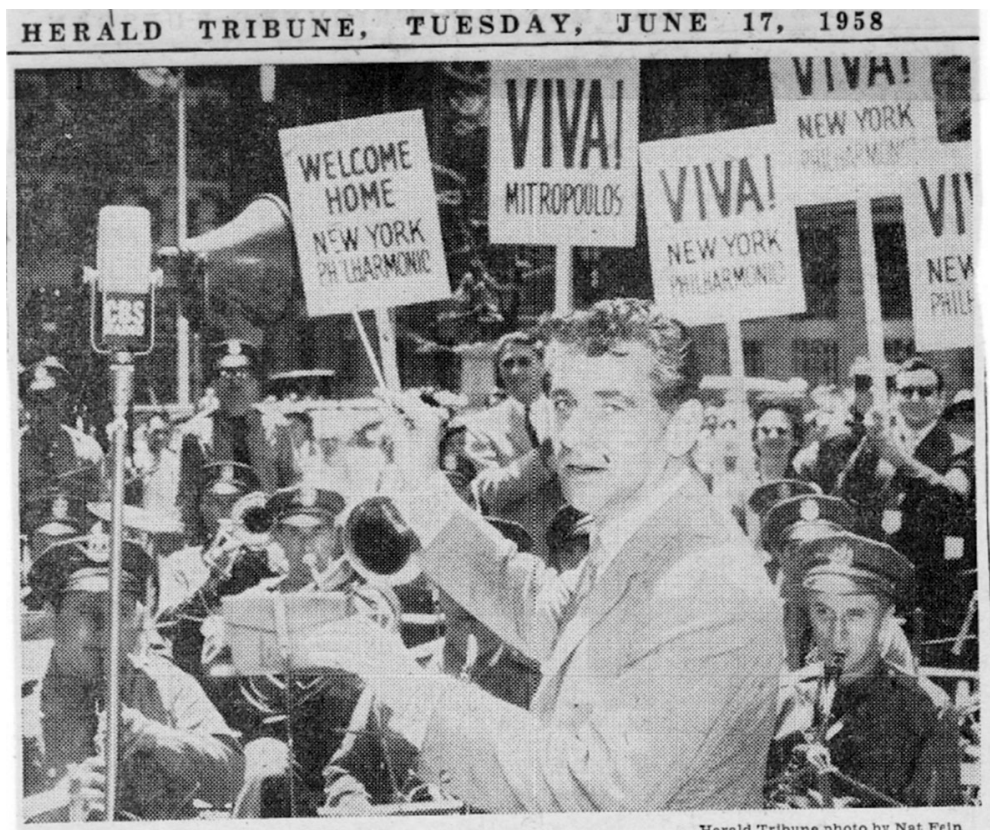

A DIFFERENT PODIUM FOR LEONARD BERNSTEIN - A surprised Sanitation A Direction of the conductor of the New York Philharmonic Symphony at City Hall Plaza yesterday as the city officially welcomed the orchestra back from its South American tour.

\section{Bernstein Leads Sanitation Band}

City Welcomes Philharmonic Home

By Jo-ann Price $\mid \begin{aligned} & \text { ies to a total audience of } 200,000 \\ & \text { persons. }\end{aligned}$ the Commerce Department ob

Leonard Bernstein, conductor ${ }^{\text {persons. }}$ After receiving a medal, a never played so well."

of the New York Philharmonic eitation and the plaudits of Mr. Celebre declared that the

Figura 73 - Reportagem do Herald Tribune destaca chegada triunfal do maestro Leonard Bernstein a Nova York, depois de turnê latino-americana patrocinada pelo governo americano, quando foi ovacionado no Rio de Janeiro e em São Paulo, em 1958.

do governo e das empresas americanas. Mesmo as feiras menores, no mesmo formato de outras ações da agência (por meio de seu Office of Private Cooperation), eram promovidas com articulação e apoio de empresas americanas interessadas no Brasil. Como foi o caso da Feira Americana do Vinho e da Uva em Jundiaí, em 1953, que tinha 
apoio da Wine Industry of America e do California Raisin Advisory Board, no fornecimento de materiais gráficos como panfletos, pôsteres, fotos e informações. ${ }^{206}$

No caso de temas de interesse do governo, a USIA contava com uma estrutura prevista para várias exibições ao redor do mundo. A primeira delas, de maior sucesso, foi organizada em São Paulo por ocasião do quarto centenário da cidade. Ela tinha como tema a energia atômica usada para fins pacíficos, intitulada "Átomos para o benefício da humanidade".

De agosto de 1954 a janeiro de 1955, a exposição localizada no Palácio das Nações ${ }^{207}$ (atual Pavilhão Manuel da Nóbrega, no Parque do Ibirapuera), recebeu a visita de mais de 400 mil paulistas. ${ }^{208}$ Segundo pesquisa interna encomendada pela USIA, a exposição em São Paulo foi um sucesso, que também se refletiu na imagem pacífica dos EUA e do Presidente Eisenhower:

De modo geral, a exibição "Átomos para o benefício da humanidade" provou ser um meio realmente eficaz de contar a história da contribuição da América para o progresso atômico, e chamar a atenção das pessoas de São Paulo, em especial, e do Brasil, em geral, sobre o tema, o que impressionou os brasileiros profundamente com os objetivos pacíficos da América, sob a liderança do Presidente Eisenhower. ${ }^{209}$

Para a promoção de feiras e exposições no exterior era comum a parceria entre a USIA e o Bureau of Educational and Cultural Affairs (CU) do Departamento do Estado, como foi o caso da Bienal

206 Documento 56.

207 Documento 75: BR 5401/ USIA Exhibit "Atoms for the benefit of Mankind" held at the Exposição do IVo Centenário da Cidade de São Paulo, from August 1954 to January 1955”.

208 Documento 45 e em Cull, 2008, p.106.

209 Documento 75: BR 5401/ USIA Exhibit "Atoms for the benefit of Mankind" held at the Exposição do IVo Centenário da Cidade de São Paulo, from August 1954 to January 1955". 
Internacional de Arte de São Paulo, de 1963, quando foram cedidos 5 funcionários exclusivos para a garantir a participação da arte americana no evento. ${ }^{210}$

Uma das feiras americanas de maior destaque no Brasil, organizada pela USIA (USIS/Rio), também em 1963, foi a "Partners in Progress", realizada na Quinta da Boa Vista, Rio de Janeiro, de julho a agosto daquele ano, com mais de 820 mil visitantes. ${ }^{211} \mathrm{Na}$ abertura, em 19 de julho, estiveram presentes o Embaixador americano no Brasil, Lincoln Gordon, o ministro da Justiça, Abelardo Jurema e o governador da Guanabara, Carlos Lacerda.

O discurso do Governador Lacerda durante a abertura do evento era elogioso ao progresso tecnológico americano mostrado na exposição, mas era mais ainda à abertura do governo americano aos movimentos de direitos civis e ao modo como os Estados Unidos tinham se construído como um "país de trabalhadores livres". Um relatório interno da USIA ${ }^{212}$ destacava o final do discurso de Lacerda, que saudava a proximidade histórica entre os povos brasileiro e americano:

Os brasileiros, na sua imensa maioria, sentem que o seu ímpeto pelo progresso é idêntico ao que bate no coração das pessoas dos Estados Unidos, assim como a sua índole para a paz e sua busca pela liberdade [...] Essa é a façanha dos Estados Unidos da América. Essa é a lição de seu grande povo, nossos irmãos. Como nosso próprio povo, eles são nascidos de muitos sangues e muitos sonhos, que cruzaram os oceanos e viajaram por distâncias imensas, para tomar a forma de um livro, o motor de um carro, uma geladeira, uma universidade, um saxofone - uma criança. ${ }^{213}$

210 Documento 11: "Exhibits Division Working Relationships with CU".

211 Documento 117.

212 Documento 117.

213 Documento 117. 


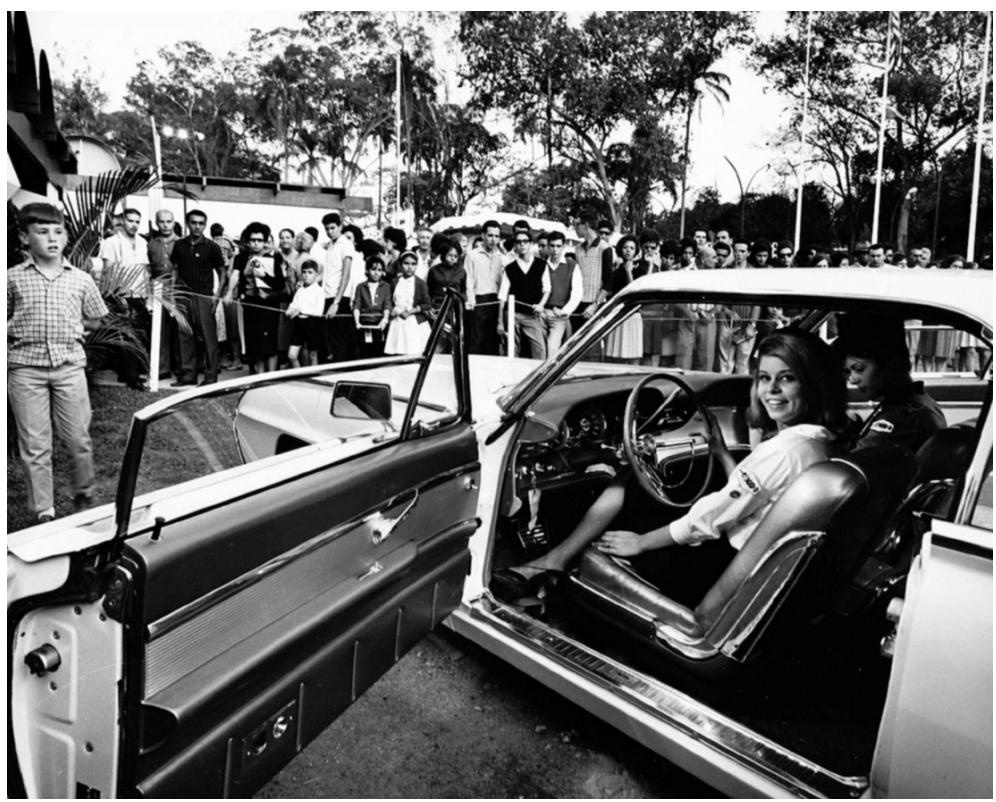

Figura 74 - Exposição "Partners in Progress", no Rio de Janeiro, recebeu mais de 30 mil visitantes por dia, em 1963, celebrando os feitos do progresso americano.

A exposição, com o tema "Aliados no Progresso", mostrava os grandes feitos tecnológicos aeroespaciais americanos e o que havia de mais moderno em estandes de empresas de carros, motos, tratores, lanchas, equipamentos médicos e domésticos. Até o final da feira, as empresas expositoras venderam mais de US\$ 550 mil dólares em máquinas e materiais americanos aos brasileiros. ${ }^{214}$

Uma das grandes atrações do evento foram as exibições do "Flying Belt Man", o protótipo de uma espécie de mochila que proporcionava o voo de um homem. Essa exibição, que também aconteceu em São Paulo na mesma ocasião, reuniu cerca de 250 mil pessoas nas duas cidades. 


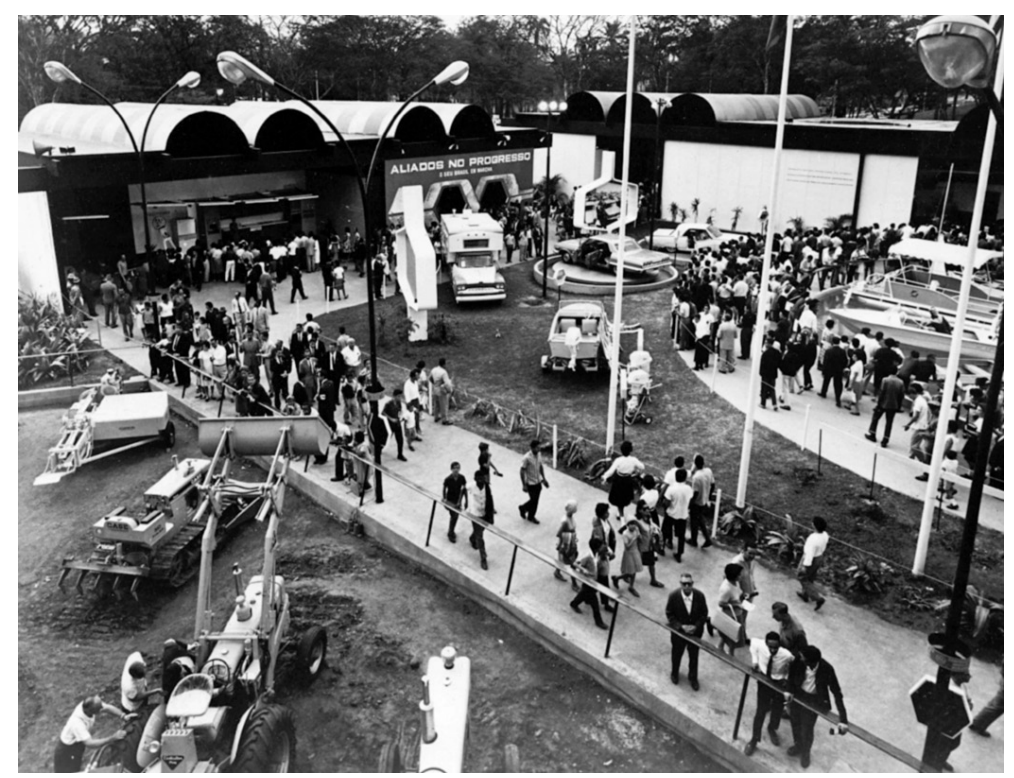

Figura 75 - Exposição "Partners in Progress", no Rio de Janeiro, tinha como tema a Aliança para o Progresso entre os países, em julho/agosto de 1963.

Durante a exposição, foram promovidos dias estaduais homenageando cada Estado brasileiro. Durante o mês da exposição, estiveram presentes à atividade os governadores mais "próximos": da Guanabara (Carlos Lacerda), de Alagoas (Luiz Cavalcanti), de Mato Grosso (Fernando Corrêa da Costa), de Minas Gerais (Magalhães Pinto), do Pará (Aurélio do Carmo), do Rio Grande do Sul (Ildo Meneghetti), do Estado do Rio de Janeiro (Badger Silveira) e de São Paulo (Adhemar de Barros). ${ }^{215}$

Além da organização geral do evento, a USIA também voltou os seus Departamentos (como o de imprensa, o de publicações, o de TV, o de rádio e o de filmes) para divulgar aos brasileiros, da melhor maneira possível, todos os resultados e impactos positivos da exposição. ${ }^{216}$

215 Documento 117.

216 Documento 117. 
Apesar do sucesso da exposição na aproximação entre americanos e brasileiros, assim como havia ocorrido em uma feira aeroespacial em São Paulo, em abril do mesmo ano, um memorando interno do diretor da USIA, Edward Murrow, antecipava um tema recorrente de discussão entre os dois povos, que devia ser tratado com paciência pelos representantes americanos no País:

Sugiro que os preparem quando chegarem, sobre as sensibilidades do Brasil e suas reivindicações relacionadas a Santos Dumont como o inventor do avião. Você conhece nossa posição e nós não repetiremos e não recuaremos uma polegada sobre os fatos verdadeiros relacionados aos Wright Brothers, que inventaram a primeira aeronave mais pesada que o ar, nós evitamos discussões controversas sobre o tema no Brasil. ${ }^{217}$

Outro programa global da USIA que teve excepcional sucesso na sua aplicação no Brasil foi o Sister Cities, que desde a criação do People-to-People Program em 1956, aproximou cidades americanas e brasileiras, com auxílio de entidades da sociedade civil e administrações municipais supervisionadas pela agência.

A ideia principal era ter no "irmanamento" das cidades uma plataforma para cooperação dos temas de ação definidos pelos comitês do People-to-People, como os já citados comitês de cartas, de hobbies, de esportes, de livros, de cartunistas, etc., aumentando o poder de penetração da cooperação americana até a sua célula local, independentemente do posicionamento dos países.

Apoiado pelo Office of Private Cooperation (OPC) da USIA, o Sister Cities tinha como referência a American Municipal Association (AMA), com sede em Washington D.C., para a gestão internacional do processo de Town Affiliation. ${ }^{218}$ A AMA representava 13 mil municípios americanos e era uma das 26 associações nacionais de

217 Documento 108.

218 Documento 52. 
cidades do "mundo livre", que formavam a International Union of Local Authorities (IULA). ${ }^{219}$

A contraparte brasileira da AMA era a Associação Brasileira de Municípios (ABM), primeira entidade de municípios do Brasil, fundada em 1946, a partir de demandas apresentadas no Congresso Interamericano de Cooperação Municipal ${ }^{220}$ e também membro da IULA. 221

Após um acordo entre duas administrações municipais que estabeleciam o irmanamento, eram criados os comitês municipais em cada cidade, com representantes da sociedade civil, como comunidade estrangeira, associações culturais e entidades privadas, que estabeleciam o rol das atividades conjuntas entre as cidades. Normalmente, o orçamento para as atividades saía da própria administração municipal, que podia contar com apoio dos membros do comitê, tanto na elaboração quanto na execução das atividades. ${ }^{222}$

No caso do Brasil, o princípio do irmanamento com cidades americanas não se deu por iniciativa das cidades, mas veio "de cima". Essas parcerias surgem a partir das indicações dos USIS no Brasil ou da USIA em Washington D.C., que encaminhavam as demandas para a AMA e só depois para a ABM e cidades brasileiras. Os irmanamentos eram como "casamentos arranjados". Em comparação aos das cidades americanas com europeias e japonesas dos anos 1950, com as cidades brasileiras vieram de forma tardia, realizados mais regularmente na década de 1960.

Reportagem do New York Times intitulada "U.S. Trying a New Way To Tell Its Story Abroad" 223 contava a maneira que a USIA prospectava novas parcerias, organizando visitas: "Visitas de cidades-a-cidades foram organizadas entre Cortland, N.Y., e Peshavar,

219 Documento 56, a IULA, fundada em 1913 e com sede na Holanda, mantinha ativa relação com a ONU, a Unesco, e a Organização Mundial de Saúde.

220 Disponível em <http://www.abm.org.br/a-abm-municipios-fortes-pais-desenvolvido/>, Acesso em: 15 dez. 2014.

221 Documento 119: "San Leandro, California Desires Brazilian Affilitation".

222 Documento 52.

223 Documento 53. 
Paquistão; Detroit, Mich., e Roterdã, Holanda; Hagerstown, Md., e Wesel, Alemanha; Boston, Mass., e Roma, Itália; e uma acontecerá entre Kansas City, Mo., e São Paulo, Brasil”. ${ }^{224}$

O grande passo do irmanamento entre cidades brasileiras e americanas começou mais fortemente a partir do governo Kennedy. Em fevereiro de 1962, seis cidades brasileiras já participavam do Sister Cities: Goiânia, GO (com Orlando, Flórida), Jundiaí, SP (com Trenton, New Jersey), Lajes, SC (com Monroe, Louisiana), Porto Alegre, RS (com Jacksonville, Flórida), Petrópolis, RJ (com Asheville, North Carolina) e Teresópolis, RJ (com Royal Palm Beach, Flórida).

Em 1963, já eram dez as cidades brasileiras participantes do programa. Além das citadas participavam Águas de Lindóia, SP (com Paso Robles, na Califórnia), Jequié, BA (com Takoma Park, Massachussets), Jundiaí, SP (que tinha feito outro irmanamento, agora com Benton Harbor, Michigan), Ribeirão Preto, SP (com San Leandro, na Califórnia) e Salvador, BA (com Los Angeles, Califórnia).

A proposta da associação das cidades se dava diretamente pela USIA, nos EUA intermediada por meio do OPC (pelo seu responsável, Snowden Chambers) ou mesmo pelo próprio diretor da agência (Murrow ou Wilson). A interlocução com as cidades brasileiras era realizada pelos responsáveis dos USIS mais próximos das localidades.

Dessa maneira, a USIA era quem administrava e geria a cooperação entre cidades no Sister Cities. Foi o caso, por exemplo, da proposta de filiação de Ribeirão Preto com San Leandro, na Califórnia. Acompanhada diretamente pelo próprio Murrow, a cidade brasileira demorava a responder sobre sua disponibilidade, o que afligia os responsáveis da cidade californiana em janeiro de 1962.

A interlocução das cidades brasileiras também era direta com os USIS. A pouca cooperação internacional entre cidades do Brasil nos anos 1950 e 1960 era diretamente operada pela USIA, como se vê em carta do prefeito de Ribeirão Preto à agência, aceitando a proposta americana. 


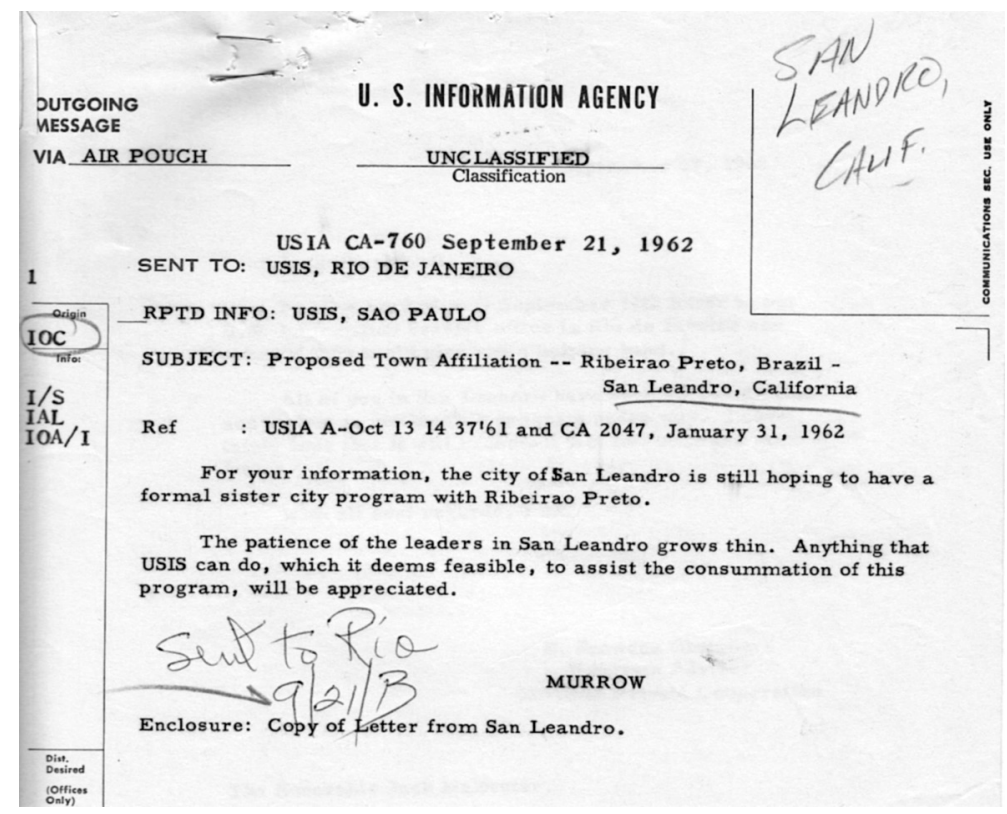

Figura 76 - Proposta de filiação de Ribeirão Preto com San Leandro, na Califórnia, feita e acompanhada diretamente pelo diretor da USIA, Edward Murrow, em 1962.

Essa fórmula foi repetida em todos "irmanamentos" de cidades brasileiras e americanas nos anos 1960, não só no processo de decisão sobre quais cidades participariam, mas também depois estabelecidas as cidades-irmãs.

A USIA (OPC) e os USIS no Brasil continuaram a acompanhar a efetividade das atividades entre as cidades. $\mathrm{O}$ começo da chamada "cooperação descentralizada" no Brasil foi bastante "centralizada" pela USIA. Como pode se observar no caso da parceria entre Takoma Park (Maryland) e Jequié (Bahia). ${ }^{225}$

Assinada em visita aos EUA do Governador baiano Antonio Lomanto Jr., também Presidente da ABM, em janeiro de 1963, a USIA continuou acompanhando a efetivação do que seria a primeira 


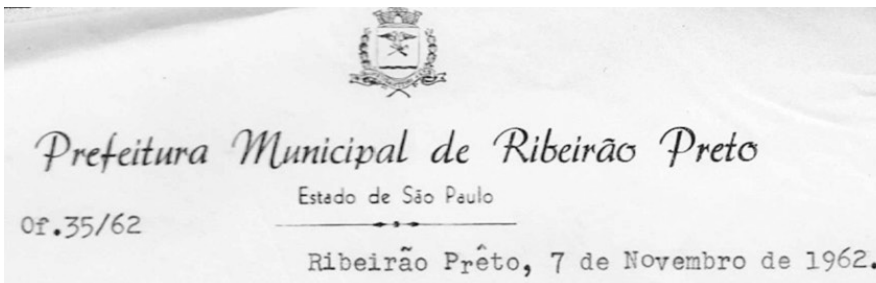

BXCEIENTISSIMO SENHOR

Com os meus respeitosos cumprimentos, tenho a grata satisfação de anexar ao presente a tese de fendida pelo sr.Antonio Machado Sant'Anna, diretor do De partamento de Educação, Cultura e Turismo desta Prefeitū ra, no IX Congresso Inter-Americano de Municípios, reali zado em Punta del Este, de 23 a 31 de outubro último, onde representou êste município integrando a Delegação Brasileira.

Trata-se de assunto de alta relevancia e que mereceu aprovação do plenário, com observação elogiosa das demais delegações, razão pela qual, ao apre sentar êsse trabalho à judiciosa observação de Vossa Excelência solicito, por obséquio, a impressão a respeito, para que a iniciativa não fique apênas no terreno das boas idéias.

Antecipando os meus agradecimentos a atenção dispensada, subscrevo-me

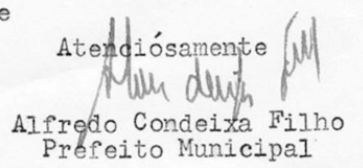

EXCEL ENTISSIMO SENHOR DOUTOR, Z,SNOWDEN CHAMBERS DIGNISSIMO CHEFA "UIFITED STATES INFORMATION SERVICE" 4.315, Pulier Dr.Kengnstn

WASHINGTON-DC

Figura 77 - Resposta do prefeito de Ribeirão Preto ao USIS: cooperação internacional das cidades nos anos 1960 era operada pela agência. 
atividade entre as cidades: a ida de uma estudante de Jequié (sobrinha da primeira-dama baiana) para Takoma. Entre outras atividades nos EUA, o Governador baiano discutiu possibilidades de empréstimos do Banco Interamericano de Desenvolvimento, no âmbito do programa "Aliança para o Progresso".

Após solucionar os trâmites operacionais (como habitação, escola e passagem), a USIA também participou da divulgação do dia a dia da jovem baiana nos EUA, seja em matéria do programa "Panorama Panamericano" (produzido pela USIA e exibido no Brasil), ou em programas comerciais americanos como "Mark Evans Show" (Channel 7).226 Jequié também participou, em junho de 1964, do Congresso da AMA, patrocinado pelo Departamento de Estado, como exemplo de caso de sucesso. Em setembro de 1964, a primeira estudante de Takoma Park chegou a Jequié para o intercâmbio de estudos de um ano no Brasil. ${ }^{227}$

Os mesmos procedimentos da USIA repetiram-se com outras cidades brasileiras, com maior intensidade principalmente nos anos de 1962 e 1963, como com Jundiaí e Trenton (NJ), com atividades amplamente divulgadas pelo VOA e pela agência de notícias nos USIS brasileiros.

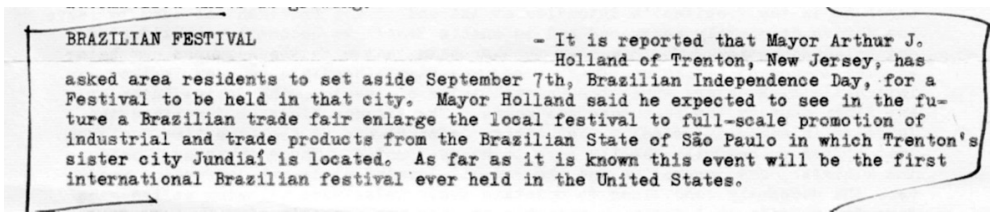

Figura 78 - Primeiro festival brasileiro nos EUA ocorreria em Trenton (NJ), cidade-irmã de Jundiaí, em maio de 1963.

Em 1963, a USIA também aproximou a cidade de Barbacena com Burlington (Iowa), iniciativa que foi elogiada pelo O Globo, em 13 de agosto do mesmo ano. Segundo a reportagem "Barbacena tem uma irmã no meio-oeste americano", que fazia parte de uma série 
de notícias do jornal chamada "Os EUA em 15 Dias". Segundo o jornal, a cidade mineira "pode sentir-se orgulhosa: dificilmente encontraria para "irmã" uma cidade mais bonita, mais limpa, mais agradável e mais rica do que Burlington, Iowa”. Mesmo não havendo registro de atividades de cooperação entre as cidades, as notícias foram favoráveis.

Um dos casos mais ativos entre as Sister Cities brasileiras foi o de Salvador e Los Angeles, como no fornecimento de material médico para a cidade brasileira, assim como 8 toneladas de brinquedos ao orfanato administrado pela Irmã Dulce, na Bahia, o que foi destacado pelo Herald-Examiner, em março de 1963.

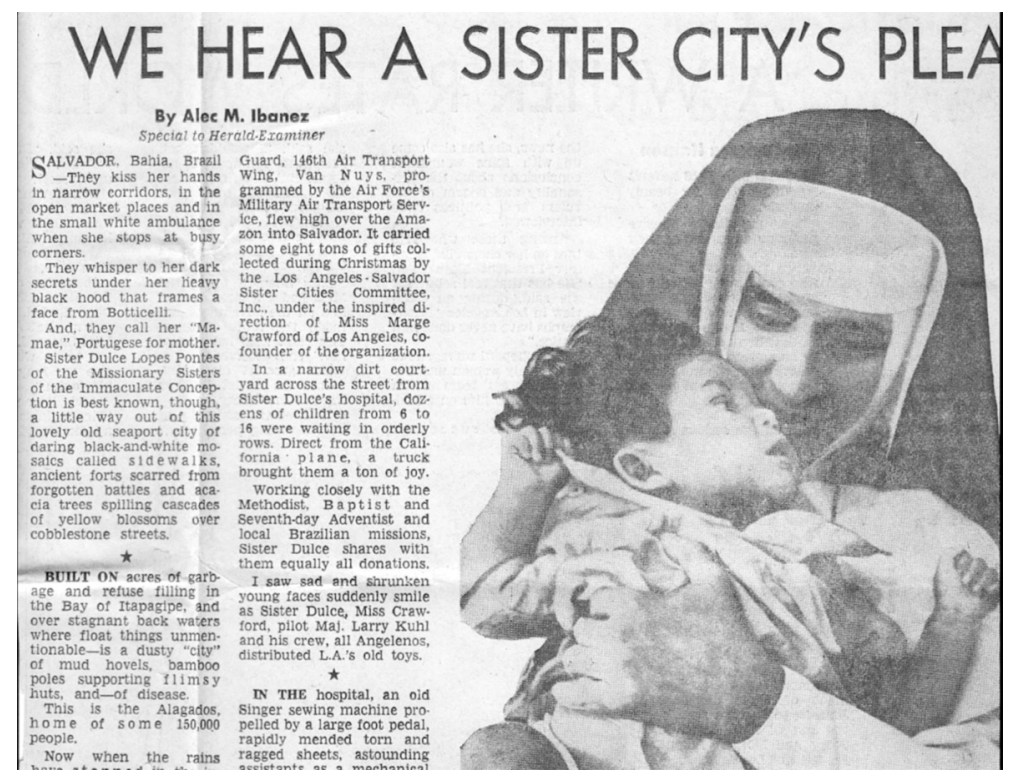

Figura 79 - Doação de brinquedos de Los Angeles para o orfanato de Irmã Dulce em Salvador, ação resultado do Sister Cities no Brasil, destacado pelo Herald-Examiner em 1963.

A USIA cumpria o papel de interlocutor com governos e legislativos locais brasileiros não só no caso do programa Sister City. Em setembro de 1963, por exemplo, ela encaminhou uma demanda 
da Assembleia Legislativa do Estado de São Paulo por maiores informações sobre os modelos e as experiências do metrô em Chicago e Nova York, para possível implantação do metrô na capital paulista. ${ }^{28}$ A agência mobilizou as cidades solicitadas e além disso, encaminhou experiências que julgava serem mais avançadas e de empresas americanas, e de Filadélfia, Boston e Washington DC.

A USIA, assim como nas outras áreas de atuação, continuou seu trabalho com as cidades nos anos seguintes, com menor intensidade. Em novembro de 1965, outras quatro cidades brasileiras estavam afiliadas e ativas no programa Sister Cities: Belo Horizonte/MG (e Austin, Texas), Coaraci/BA (e Great Bend, Kansas), Itapetinga/ BA (com Dairy Valley, Califórnia), São José dos Campos/SP (e Hanford, Califórnia).

Com a extinção de seu Office of Private Cooperation em 1967, a USIA não deu maior continuidade ao programa Sister Cities até 1969, quando o seu diretor à época, Frank Shakeaspeare, declarava publicamente o compromisso de reanimar o trabalho da agência junto à AMA e a National League of Cities americana. Apesar da vontade, a USIA não mostrou efetivamente a mesma força e compromisso do início dos anos 1960, ao menos junto às cidades brasileiras.

\section{A USIA, o rádio, a televisão e o cinema no Brasil}

Além dos programas para os grupos prioritários, e considerando que o acesso à maioria da população do Brasil era dificultado pelo alto índice de analfabetismo, pelo tamanho do País e pela precariedade de seu sistema de transporte, o rádio era o mais importante instrumento para alcançar o país como um todo.

Antes mesmo da USIA, a estratégia americana já contava com o rádio (e o Voice of America) para alcançar as regiões mais longínquas do mundo, como mostra o gráfico da IIA de 1952, a seguir: 


\section{VOICE OF AMERICA}

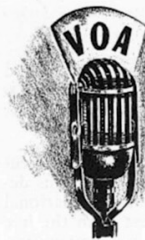

The VOA delivered a more intensive message during the period, particularly behind the Iron Curtain. The message went out over powerful transmitters, ranging up to 200,000 watts, in a system of networks larger than the three big American broadcasting systems combined. The system includes 42 stations in the United States and 36 U.S.-owned or -leased transmitters overseas. In addition, the Courier, a converted Coast Guard cutter equipped as a sea-going transmitter, was tested successfully in the Caribbean and dispatched to its first duty station in the Mediterranean. The Munich Radio Center added four languages to its daily broadcasting over the Iron Curtain.
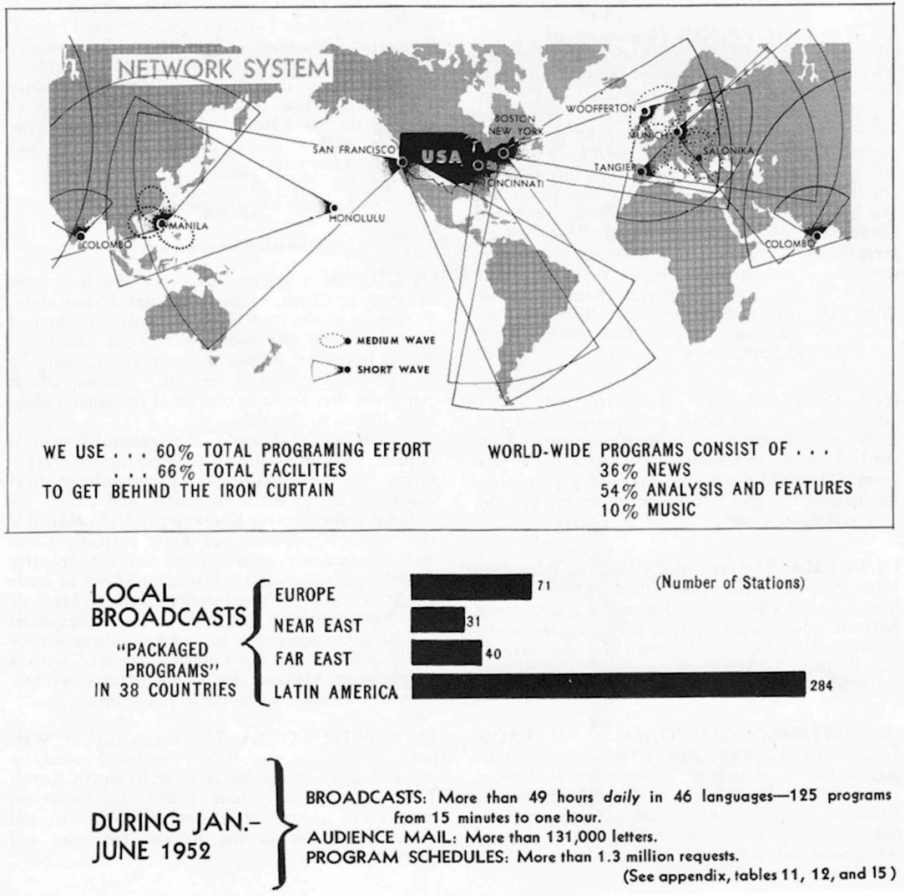

Figura 80 - "Voice of America" e a estratégia de rádio americana no começo dos anos 1950 .

Com o advento da USIA e seus cortes orçamentários iniciais (que se refletiram na diminuição de programas produzidos pelo VOA também em português), ${ }^{229}$ o espaço para transmissão do VOA começou a ser ocupado pelos programas produzidos localmente nos USIS 
de cada região do Brasil. A medida emergencial deu frutos positivos, diminuindo também os custos, assim como abordou características e temas mais conhecidos das populações locais. Essas seriam mescladas com as informações dos EUA que chegavam aos USIS por meio de sua agência de notícias. ${ }^{230}$

Em 1953, o sinal dos programas da USIA transmitidos pela WRUL em espanhol para o Brasil (principalmente em São Paulo) era nítido, ${ }^{231}$ mas de acordo com a nova orientação da USIA isso não era suficiente. Para ter maior aceitação do público brasileiro, os programas deveriam ser produzidos localmente, transmitidos nas principais estações comerciais, e como era padrão da USIA, não deveriam ser identificados como produzidos pelo governo americano.

Por isso, os programas da WRUL no Brasil em 1954, como "O Vespertino do Ar", ${ }^{232}$ começaram a ser transmitidos, em português, a 50 milhões de ouvintes, patrocinados por Gillette e Time-Life International. ${ }^{233}$ Eles eram reproduzidos em estações locais como a Rádio Clube do Pará (Belém/PA), Rádio Difusora (Petrópolis/ RJ), Rádio Emissora de Piratininga/SP, Rádio Rio Preto (Rio Preto/SP), Rádio Educadora de Campinas/SP, Rádio Difusora de Agudos/SP, Rádio Difusora de Assis/SP, Rádio Bebedouro/SP, Rádio Difusora de Cafelândia/SP, Rádio Difusora de Catanduva/SP, Sociedade Rádio Clube de Garça/SP, Rádio Liberdade de Guaratinguetá/SP, Rádio Difusora de Mirassol/SP, Rádio Difusora de Monte Aprazível/SP, Rádio Clube de Oswaldo Cruz/SP, Rádio Clube Marconi de Paraguaçú Paulista/SP, Rádio Difusora de Pompéia/SP, Rádio Difusora de Rancharia/SP, Sociedade Rádio Difusora de Regente Feijó/SP, Sociedade Rádio Difusora de São João da Boa Vista/SP, Rádio Difusora de Sertãozinho/SP, Rádio Mayrink Veiga/RJ e a Rádio Ministério da Educação/RJ. ${ }^{234}$

230 Documento 124.

231 Documento 71: "ZP 5302, Radio Listening, Multi Latin America, give-away offer on WRUL (responses), nov-dec 1953”.

232 Documento 78.

233 Documento 125.

234 Documento 125. 
No mesmo ano, o País chegava a 3 milhões de aparelhos de rádio que transmitiam os programas da WRUL como "A Voz da Liberdade", ou os feitos pela USIA para exibição em emissoras comerciais, como "Comentários de Al Neto", "Verdade ou Mentira” (na Rádio Nacional), "Rua do Sossego" (na Rádio Tupi), "História de Chinelo” (Rádio Nacional), "Repórter Esso” (Rádio Nacional), "Curiosidades" (Rádio Nacional) e "Ponta de Lança” (na Rádio Tupi). ${ }^{235}$

Nas pesquisas internas da USIA, 65\% dos brasileiros se informavam pelo rádio. E entre os programas de notícias, o "Repórter Esso" era o mais ouvido, ao menos nas grandes cidades brasileiras, com 49\% de preferência entre os ouvintes no Rio de Janeiro e 24\% em São Paulo. ${ }^{236}$

Para exibição dos programas nas principais emissoras de rádio do país e nas pequenas rádios locais, a USIA fez acordos sigilosos com a maior cadeia de rádio brasileira para exibição de seus programas em grande parte do Brasil, como pode verificar-se pelo contrato com “Os Diários Associados”, que já vigorava, pelo menos, desde 1951.

Como mostram os trechos do documento abaixo, para exibição dos programas da USIA "Nos Bastidores do Mundo - com Al Neto" e "A vida que o mundo leva", a USIA pagava diretamente a Assis Chateaubriand cerca de US\$ 5 mil dólares mensais (sem contar as taxas adicionais) para exibição em cidades fora do Rio de Janeiro, e em Belo Horizonte, Porto Alegre e São Paulo. O contrato havia sido feito seguramente desde 1951 e durou pelo menos até dezembro de 1955, data deste informe interno.

235 Documento 71.

236 Documento 71. 
On May 1, 1951, a contract was signed providing for payment of an amount that "in no case shall exceed US\$5,341.80 per month" for the medium and shortwave broadcast, six days a week on four stations outside Rio de Janeiro of a 5-minute international news commentary entitled "Nos Bastidores do Mundo." The contract was to run until June 30, 1952, and was subject to extension (or cancellation).

A Confidential telegram, No. 535, dated October 18, 1951, requested sufficient additional funds to pay Senhor Chateaubriand $\$ 12,500$ monthly for broadcasting A Vida que 0 Mundo Leva. On November 26 (Telegram No. 682) warned that if requested funds were not forthcoming by December 3, program would be cancelled. This was done on December 3, but the Department was

Figura 81 - Contrato da USIA que mostrava o pagamento direto feito a Assis Chateaubriand, pela exibição dos programas da agência nas estações da cadeia de rádio dos Diários Associados, pelo menos desde 1951 a 1955.

A aliança entre Chateaubriand e a USIA era estratégica para ambos. ${ }^{237}$ Quando discutiam sobre os pagamentos devidos aos "Diários Associados", o jornalista e empresário brasileiro deixava claro que mesmo se não fosse pago, ele gostaria continuar a exibir os programas da agência, por sua própria conta, pela grande importância do que era produzido pela USIA:

Em 26 de novembro [1951] (Telegrama No. 682 avisou que se os fundos requeridos não viessem até 3 de dezembro, o programa seria cancelado). Isso foi dito em 5 de dezembro e o senhor Chateaubriand insistiu na continuação do programa até $1^{\circ}$ de janeiro, 1952 "por sua própria conta, se necessário, porque ele considera a eficiência do programa de suma importância”. O telegrama acrescentou que o senhor Chateaubriand "solicitou à Embaixada que avisasse o Assistant Secretary Miller que, em sua opinião, o Departamento deveria aproveitar-se inteiramente de todos recursos de imprensa de Chateaubriand para a Campaign of Truth. ${ }^{238}$

Em 1956, a USIA exibia nas grandes emissoras de rádio, além do programa de Al Neto, novas atrações como "Você se lembra", "Os

237 Haines (1989, p.171) também destaca a aliança entre o Governo americano e Assis Chateaubriand.

238 Documento 74. 
vencedores da vida", "Noveleta Panamericana" e os musicais "Hit Parade" (transmitido pela Radio Metropolitana do Rio de Janeiro) 239 e "Clube do Disco". ${ }^{240}$

O historiador brasileiro Antonio Pedro Tota (2005) mostrou como Al Neto, funcionário da embaixada americana no Rio de Janeiro, mesclava curiosidades, variedades e opiniões políticas anticomunistas e pró-americanas, sem nunca mencionar sua ligação com a USIA. ${ }^{241}$

Segundo relatório interno da agência em 1957, os programas de Al Neto gravados pelo USIS do Rio de Janeiro, eram produzidos para disseminar comentários políticos e discutir frequentemente, de maneira positiva, a cooperação entre Brasil e EUA. Segundo o mesmo relatório, o programa de $\mathrm{Al}$ Neto era diário, com duração de 5 minutos e distribuído em discos a 35 estações ao redor do País. Os roteiros de Al Neto também eram usados por cerca de 300 estações, lidos pelos locutores locais. Esses comentários eram amplificados também em praça pública, por cerca de 300 caixas de som espalhadas pelo país. ${ }^{242}$

O sucesso do programa era grande também na capital do País: em 1957, 44\% dos cariocas identificavam o programa de Al Neto espontaneamente. ${ }^{243}$ No fim dos anos 1950, além de seu programa de rádio, Al Neto também escrevia colunas em jornais brasileiros, no Rio de Janeiro, Curitiba, Aracaju, Campos, Londrina, Itapetininga, e com grande sucesso em Joinville. Na ocasião, Al Neto também tinha um programa de TV (patrocinado pela "América Fabril") exibido no Rio de Janeiro, no qual entrevistava celebridades. ${ }^{244}$

239 Documento 125.

240 Documento 12.

241 Parte do acervo de Al Neto está disponível no sítio eletrônico do Núcleo de estudos de Política, História, e Cultura da Pontifícia Universidade Católica de São Paulo. Disponível em <http://www.pucsp.br/polithicult/midiateca/ bastidores_mundo1.html> Acesso em: 23 jan. 2014. Haines (1989, p.171) também menciona o programa de $\mathrm{Al}$ Neto.

242 Documento 125.

243 Documento 12.

244 Documento 138. 
Os programas de rádio da USIA ao longo dos anos 1950 conquistaram um importante público nas maiores cidades brasileiras. A grande preferência dos ouvintes brasileiros entre os programas da USIA eram os musicais; em segundo lugar, estavam as rádio-dramaturgias e em terceiro lugar as comédias e os noticiários. ${ }^{245}$

Em Porto Alegre, por exemplo, o programa "Você se lembra" era o preferido de um terço da população gaúcha em 1957. ${ }^{246}$ Produzido localmente e patrocinado pela American Corn Products, o programa tinha completa supervisão do Departamento de Rádio da USIA e dedicava-se a lembrar de fatos nacionais e internacionais do passado, bem como a relacioná-los com os acontecimentos da ocasião. ${ }^{247}$

Outro programa produzido localmente pelo USIS no Rio de Janeiro era "Os Vencedores da Vida”, um "programa documentário dramatizado", ${ }^{248}$ que contava a história de lideranças brasileiras nos campos da indústria e das artes, com ênfase especial ao empreendedorismo e ao espírito do capitalismo brasileiro, que segundo a descrição do programa, teriam ajudado a construir as bases do País. Esse também era distribuído a partir do Rio de Janeiro, em discos, aos outros postos locais no País. ${ }^{249}$ Outro grande destaque de popularidade dos programas da USIA era o programa “A Casa do Tio Sam”, lembrado espontaneamente por $17 \%$ da população de São Paulo.

Mesmo com o sucesso dos programas ("não-assinados") da USIA transmitidos em rádios comerciais brasileiras desde 1942, a agência continuou produzindo seu programa "assinado" mais célebre, o "Voice of America". ${ }^{250}$ Na maior parte dos anos 1950 e 1960, a USIA produzia três horas diárias do VOA em português especialmente para o Brasil, ${ }^{251}$ além de disponibilizar "feeds" (transmissões

245 Documento 12.

246 Documento 12.

247 Documento 125.

248 Documento 125.

249 Documento 125.

250 Documento 124. Com exceção de 1953, quando o VOA foi paralisado por questões orçamentárias.

251 Documento 128. 
diretas), em inglês, para 50 estações brasileiras, que os retransmitiam em ondas curtas para todo o Brasil. A agência também oferecia programas gravados, que eram redistribuídos em ondas médias por 100 estações locais. ${ }^{252}$

Em 1961, os programas do VOA para o Brasil misturavam, de maneira geral, notícias comentadas, a cobertura jornalística de temas de interesse do público brasileiro, especiais sobre literatura, história, ciência e eventos culturais americanos, músicas americanas e aulas de inglês. ${ }^{253}$ Eram recorrentes os temas como os principais avanços tecnológicos americanos, discursos dos Presidentes Eisenhower e Kennedy e o detalhamento de programas americanos para a região como, os "Peace Corps", a "Aliança para o Progresso", o "Food for Peace" e as ações do Banco Interamericano de Desenvolvimento. ${ }^{254}$

Após o governo Johnson, como em todas as áreas da USIA, o rádio e o VOA gradativamente foram perdendo força, orçamento e pessoal. Em relatório interno da USIA para avaliação do programa de rádio do Brasil em 1969, observava-se o começo do declínio da estratégia de rádio no Brasil a partir de 1967: "Naquele momento da pesquisa no Brasil, nós já tínhamos sofrido cortes substanciais na plataforma de rádio, por causa das limitações de orçamento e de pessoal que começaram a ser sentidas no outono de 1967”. ${ }^{255}$

Com o aumento das transmissões televisivas no Brasil, a USIA também participou com produções próprias voltadas ao público brasileiro. De 1953 a 1955, com um crescimento de 85\% no número de televisores no país - sendo 55 mil aparelhos no Rio de Janeiro e 65 mil em São Paulo - as estações de TV (quase sempre ligados às cadeias de rádio) também se multiplicavam..$^{256}$

Em 1955, a USIA destacava a existência de três emissoras em São Paulo, cada uma com 40 horas de transmissão semanais: a TV Tupi,

252 Documento 124.

253 Documento 124.

254 Documento 128.

255 Documento 85.

256 Documento 95: "IM-46-55, Recents Developments in Latin American Television, March 31, 1955”. 
canal 3; a TV Record, canal 7; e a TV Paulista, canal 5. A agência também alertava para o surgimento de uma TV ligada à Rádio Bandeirantes - que seria o canal 13 - em São Paulo, além da criação de emissoras ligadas à TV Tupi em Belo Horizonte e Porto Alegre. ${ }^{257}$

No Rio de Janeiro já existiam: em 1955, a Rádio Tupi-TV, canal 6, com 55 horas de transmissão por semana; a TV Rio, controlada pela TV Record de São Paulo; e a TV Roquete Pinto, de perfil educativo, pertencente à Prefeitura do Rio de Janeiro, que transmitia 50 horas por semana pelo canal 2. ${ }^{258}$ Até 1956, quando o Brasil já tinha 200 mil aparelhos de TV, ${ }^{259}$ o Governo abriu 16 concessões de televisão, sete delas no Rio de Janeiro, sete em São Paulo, uma em Belo Horizonte e uma no Recife. ${ }^{260}$

O Brasil já fazia parte de uma estratégia de programas de TV da USIA, que eram distribuídos em 21 países do mundo e dublados pelas emissoras locais. ${ }^{261} \mathrm{Em} 1957$, quando o Brasil já atingia 405 mil aparelhos de TV, ${ }^{262}$ a USIA distribuía programas de notícias como o "News in Review" e o "Report from America", além de um programa específico chamado "Mirante", ${ }^{263}$ nas emissoras cariocas, paulistas e mineiras.

No mesmo ano de 1957, levantamentos internos da USIA sobre a televisão no mundo destacavam que o Presidente Juscelino Kubistchek havia cedido seis concessões a Assis Chateaubriand (chamado no informe da USIA somente de "Chateaubriand"), de acordo com a demanda do jornalista em abrir emissoras de TV no interior do Estado de São Paulo, como mostra o documento abaixo:

257 Documento 95.

258 Documento 95.

259 Documento 131.

260 Documento 130.

261 Documento 129.

262 Documento 132.

263 Documento 129. 
BRAZII

The President of the Republic has granted a concession to Radio Tupi Difusore of Sao Paulo (Chateaubriand owned) for the installation of TV stations in Riberao Preto, Campos do Jordao, Santos (Santos is reported to have a TV station already.-Bd.), Campinas, Marilia, and Sao Jose do Rio Preto, all located in the State of Sao Paulo. The installation of these new TV stations has resulted from the efforts made by the "Emissoras Associadas" of Sao Paulo, which has declared its intention to expand TV throughout the interior of the State.

Figura 82 - Informe da USIA apontava para a cessão de TVs feita por Juscelino Kubitschek para "Chateaubriand” no interior de São Paulo, em 1957.

Para o Rio de Janeiro, em 1957, a USIA dirigia e supervisionava o "Quero saber mais", um programa de perguntas e respostas patrocinado pela "Coca-Cola" (conhecido por 41\% dos espectadores cariocas) e que alternava curiosidades e informações relevantes para os EUA, como energia atômica, temas políticos contemporâneos, esporte e música. ${ }^{264}$

A partir de 1958, os programas de TV da USIA dedicavam-se, principalmente, a reforçar os benefícios da cooperação americana no Brasil, como o Point IV e a "Aliança para o Progresso". Para isso, a agência produzia, em Washington D.C., o programa "Panorama Panamericano". Com 15 minutos semanais, o "Panorama" era transmitido pela TV Tupi e pela TV Excelsior, como reportagens que faziam parte de programas mais longos desses canais, e contava aos brasileiros todos os benefícios e casos de sucesso das parcerias com os EUA no País. O "Panorama" era transmitido aos sábados, domingos ou às segundas-feiras, às 17h30, $18 \mathrm{~h} 40 \mathrm{ou}$ $10 \mathrm{~h} 45 .{ }^{265}$

Além do "Panorama", no início dos anos 1960, a USIA também produzia para o Brasil um programa musical chamado "Jazz na América" (esse até outubro de 1962) e outro chamado "Entrevista da Semana", que durante cinco minutos dedicava-se sempre a algum tema de interesse da agência e era transmitido pela TV Paulista,

264 Documento 138.

265 Documento 128 e Documento 12: “USIA/IRS/R/ TV Survey in São Paulo May, 1963". 
normalmente às quartas-feiras, sextas-feiras ou sábados, às $18 \mathrm{hs} \mathrm{ou}$ 20hs, de acordo com a disponibilidade da emissora. ${ }^{266}$

A partir de abril de 1962, quando foram revogadas as barreiras anteriormente impostas por Jânio Quadros a programas estrangeiros na televisão brasileira, ${ }^{267}$ os programas "privados" americanos atingiram grande presença e audiência nos canais brasileiros com programas como "Papai sabe tudo", "Os Flintstones", "Lassie", "I love Lucy”, "Bat Masterson", "Rin-Tin-Tin”, "Além da Imaginação", "Três Patetas", "Top Cat" (o "Manda-Chuva”), "Rota 66”, entre outros. ${ }^{268}$

Mas a política de audiovisual da USIA não tinha começado com a TV. Na verdade, ela seguia uma tradição do governo americano em produzir filmes, com parcerias ou não, em conjunto com estúdios de Hollywood. Essa, como muitas outras ações, teve suas raízes em Creel, passando pelo Birô de Rockefeller (Tota, 2000), com filmes específicos para América Latina, e continuava com a USIA. A tradição continuava, com filmes em formatos de documentários, jornalísticos ou ficcionais, exibidos em centros binacionais e salas comerciais de cinema.

O filme sobre a visita do Presidente Dutra aos EUA, produzido em 1949, por exemplo, mostrava o encontro com Truman e a ótima relação pessoal dos dois Presidentes, refletindo o histórico de boas relações entre os dois países. Entre outras visitas que fazem parte do filme, Dutra vai ao Tennessee conhecer a usina hidrelétrica em Chattanooga, experiência de interesse do Presidente brasileiro. ${ }^{269}$

A USIA continuou a fazer filmes específicos para o público brasileiro, sempre reforçando as bandeiras políticas americanas e a boa relação entre os países. É o caso do filme "Atomic Medicine in Brazil”, realizado no Brasil em 1954, pela produtora Herbert Richers. Ele contava como a energia atômica podia ajudar no tratamento de casos de câncer, por meio da cooperação americana em hospitais,

266 Documento 12: "USIA/IRS/R/ TV Survey in São Paulo May, 1963”.

267 Documento 135.

268 Documento 134.

269 Documento 136. 
instituições como a Escola Paulista de Medicina e o Instituto Central do Câncer de São Paulo. ${ }^{270}$

A partir de 1955, as crescentes barreiras governamentais para exibição de filmes produzidos no exterior fez com que, cada vez mais, a USIA contratasse produtoras locais para seus filmes no Brasil. ${ }^{271}$ Um exemplo disso era o projeto da USIA exibido em cerca de mil salas comerciais, bibliotecas e postos móveis do USIS do Brasil durante todo ano de 1959: a série de filmes "A escola agora é outra", mostrava os avanços na educação básica brasileira alcançados com ajuda do Point $I V .^{272}$

A parceria da USIA com as companhias cinematográficas brasileiras proporcionava a exibição de seus filmes nas salas comerciais. A maior produtora e distribuidora do Brasil no começo dos anos 1960, por exemplo, era parceira da USIA. ${ }^{273}$ Em 1962, Luiz Severiano Ribeiro Jr., dono e Presidente da Cinegráfica São Luiz S.A. e companhias associadas, esteve em Washington DC para encontrar-se com a USIA.

Segundo o responsável pelo Departamento de Filmes da USIA naquele ano, Anthony Guarco, Ribeiro Jr. era o homem que controlava a indústria cinematográfica brasileira, com mais de 1.800 salas de cinema e cerca de 8 filmes produzidos por ano. Além disso, era responsável pela distribuição de filmes da maioria das corporações americanas, como a 20th Century Fox. ${ }^{274}$

Recebida pela diretoria da USIA na ocasião, a Cinegráfica São Luiz foi a responsável pela exibição de 12 curtas-metragens da USIA em 1.800 salas ao redor do Brasil, no ano de 1962. Entre esses, conta-se inclusive um filme colorido sobre a posse do Presidente Kennedy. ${ }^{275}$

270 Documento 137.

271 Documento 51: "1955: Brazil prohibits importation of Newsreels hence produced locally".

272 Documento 139.

273 Documento 140.

274 Documento 140.

275 Documento 140 
Em 1962, a USIA também exibia a série semanal de filmes "Horizons", que mostrava os impactos positivos da "Aliança para o Progresso" na América Latina, sendo exibido em mais três mil e duzentas ${ }^{276}$ salas comerciais no Brasil para mais de 1,5 milhão de pessoas naquele ano. ${ }^{277}$

O "Horizons" foi realizado pelas produtoras mais importantes do Brasil, como a mencionada Cinegráfica São Luiz (quatro histórias em três newsreels), Herbert Richers (três histórias em três newsreels), Carlos Niemeyer (três histórias em dois newsreels) e Ponte Gráfica, uma associação de pequenas produtoras (com uma história feita por dez diferentes companhias). ${ }^{278}$

As parcerias com produções locais continuaram, assim como a exibição de filmes produzidos para todo mundo, sempre fortalecendo os principais programas do governo e valorizando o perfil dos Presidentes americanos como lideranças globais.

Como já foi visto, após a morte de Kennedy, a USIA, em tempo recorde, produziu o filme "The President", que mostrava os funerais de JFK e a subida ao poder do Presidente Johnson, valorizando suas qualidades para enfrentar a crise interna e os desafios externos que os EUA sofriam na ocasião.

"The President" começou a ser exibido nos cinemas brasileiros em fevereiro de 1964, com o devido acompanhamento do Departamento de Pesquisa da agência, que media a aceitação do público local ao filme e à figura do novo Presidente americano como liderança capaz de influenciar o mundo (e o Brasil) positivamente. Em pesquisa da USIA em abril de 1964, feita com os espectadores do filme, era medida a confiança dos brasileiros aos EUA como líder de outros países, contra os principais problemas mundiais naquele ano. ${ }^{279}$

Pelo menos entre os brasileiros que tinham acabado de ver o filme, os resultados eram positivos para a USIA e os EUA: 10\%

276 Documento 117.

277 Documento 59.

278 Documento 117.

279 Documento 86: "BR 6401, Brazil, Reaction to "The President” Film, Apr. 1964". 
não sabiam, 14\% achavam que os EUA não tinham muita (ou tinham pouca) capacidade de liderança mundial, enquanto que $76 \%$ dos brasileiros acreditavam que o Presidente Johnson e seu país tinham muita (ou considerável) capacidade para liderar outros países. $^{280}$

Após o golpe que depôs o Presidente Goulart, em 14 de abril de 1964 a USIA enviou um memorando a todas as suas diretorias internas, ${ }^{281}$ com a nova orientação da agência para a linha editorial a ser adotada a partir de então, tanto oralmente, quanto nos materiais a serem produzidos relacionados ao ocorrido no Brasil. Basicamente, eram oito recomendações:

1. Internamente a USIA orientava a todos que documentassem e repassassem à Agência todos os sinais de infiltração comunista na "Brazilian Life", seja no governo, nos militares, no trabalho, no meio estudantil, na imprensa e na "intelligentsia";

2. Para os materiais a serem produzidos para o público latino-americano, a agência deveria destacar a influência castrista na "conspiração comunista" do Brasil e reforçar que a mesma estratégia era usada em todos os países da região;

3. Mostrar, a todo momento, o imenso apoio popular dado à derrubada do Presidente Goulart, o que daria legitimidade à "Revolução";

4. Mostrar elementos comunistas chineses e soviéticos infiltrados, que tentavam minar o sistema constitucional brasileiro;

5. Exibir todas as evidências materiais, como armas ou documentos, que provassem a determinação comunista em tomar o Brasil;

6. Usar fontes brasileiras nas reportagens e materiais;

7. Não mencionar nomes dos considerados comunistas envolvidos;

280 Idem.

281 Documento 94: "Treatment of Infiltration and Subversion in Brazil, April 14, 1964" 


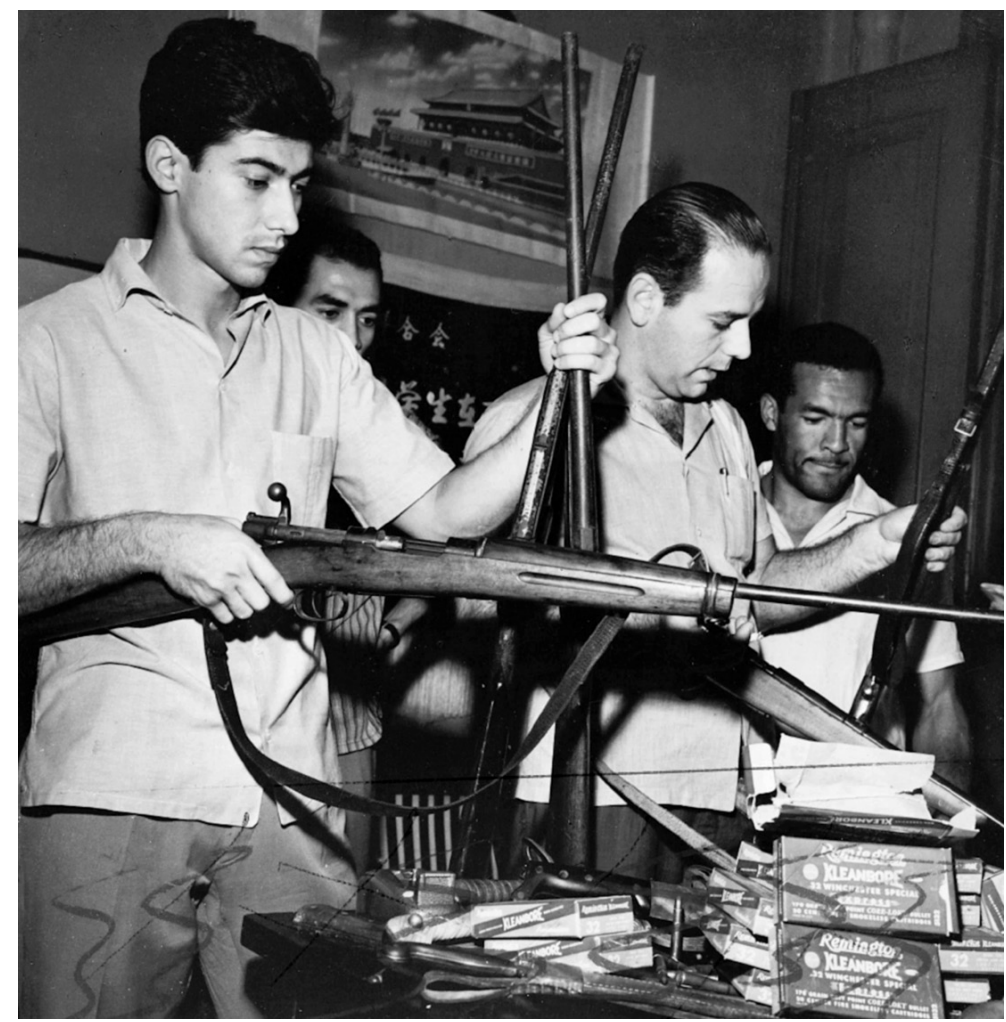

Figura 83 - Foto tirada pela USIA, demonstrando as provas materiais (armas) da infiltração comunista no Brasil, que segundo recomendação interna da agência, justificava a derrubada de Goulart.

8. Não havia interesse em incentivar "vendettas" contra Goulart, Brizola e outros membros graduados dos governos, mas usar (e explorar) todas as provas que expusessem a ligação desses com um possível golpe comunista no Brasil.

As reportagens, filmes e fotos produzidas a partir daí seguiam essa orientação, como é o caso das Figuras 35 e 51, tiradas pelos USIS brasileiros em 1964. Elas tentavam mostrar a ligação de estudantes brasileiros com comunistas chineses, ou centros acadêmicos com 
pôsteres do Che Guevara, explicitando o perigo comunista que justificava a "revolução".

Assim como a Figura 83, a seguir, também tirada pela USIA em 1964, mostrava as evidências "materiais" da tentativa do Levante Comunista no Brasil. A descrição da foto, encontrada nos arquivos americanos, reforçava essa ideia: "Brasil: armas confiscadas de organizações comunistas e indivíduos que planejaram a revolução comunista. Fonte: USIS Brasil”. ${ }^{282}$

As diretrizes internas, quanto à posição a ser seguida pelas coberturas da USIA sobre o golpe no Brasil, foram cumpridas em todos os seus materiais a partir daí. Em geral, as atividades da USIA no Brasil, desde sua criação até o Golpe Militar em 1964, seguiram mais um vez, à risca e com sucesso, as orientações do estudo feito por Leo Bogart em 1952, sobre o que uma agência americana de informação deveria ser:

O homem da rua é muito poderoso. $\mathrm{O}$ americano médio tende a pensar que o povo no exterior, o povo do Irã, por exemplo, como sem muito poder. Mas eles podem derrubar governos com maior eficácia do que nós poderíamos, por meio do voto, algumas vezes [...] Na América Latina, as classes mais baixas estão se armando e começando a atirar. [...] Esses fatos tornam necessário que a USIA faça sua mensagem chegar aos mais humildes e analfabetos. Se a maioria das pessoas em um determinado país for favorável aos EUA, a ação pró-americana sobressairá, mesmo se os grupos no poder forem antiamericanos. (Bogart, 1995, p.16) 


\section{3 \\ O OCASO DA USIA}

O mundo que nos amava agora nos odeia. Nós nos odiamos.

George Creel, 1920b, p.362 comentando os efeitos do fim do CPI.

Como pôde ser notado nos segundo e terceiro capítulos, a partir do governo Johnson houve uma visível diminuição do volume das atividades em todas as áreas de atuação da USIA e um afastamento da agência do centro das decisões da política externa, fruto da visão dominante dos Presidentes americanos (de ambos os partidos) e do contexto internacional que se desenhava após a segunda metade da década de 1960. Esse processo refletiu-se diretamente na redução do orçamento e pessoal da USIA até o seu fim, em 1999 (Bogart, 1995, p.xxiv e xxii).

A diminuição também foi sentida na quantidade de representações locais no exterior (centros binacionais, bibliotecas e USIS), no número de publicações e traduções de materiais, no volume de notícias, na produção de programas de rádio e filmes para TV e cinemas.

No Brasil, esse processo começou a ser sentido mais fortemente a partir dos anos 1970. Segundo entrevista feita com Carl Howard (2014), ex-information officer da USAID, press attaché e Country Public Affairs Officer no Brasil, no USIS do Rio de Janeiro em 1971, 
a orientação era diminuir o volume de atividades de imprensa, em relação às desenvolvidas nos anos 1950 e 1960: "Assim que eu cheguei, em maio de 1971, eu fui orientado para começar a diminuir gradativamente o tamanho dos serviços de imprensa, que tinha redatores, editores, um artista e sofisticados equipamentos de impressão". $\mathrm{Na}$ ocasião, Howard (ibidem) tinha uma equipe de 20 pessoas que trabalhavam na produção de materiais gráficos qualificados para divulgação da "Aliança para o Progresso", inclusive com representações no Nordeste.

Durante as décadas de 1960 e 1970, apesar do encolhimento do volume das atividades, ainda foram feitos esforços para cooperação a longo prazo, no intercâmbio de estudantes, no ensino de inglês e nas atividades cultural. O trabalho ativo com os principais jornais, revistas, assim como nos principais canais de televisão no Brasil, mesmo com menor intensidade, continuou nos anos seguintes.

Tanto Howard - que trabalhou durante 12 anos no País, ao longo das décadas de 1970, 1980 e 1990, no Rio de Janeiro, em Brasília e São Paulo - quanto Don Mathes, Branch Public Affairs Officer no Brasil (de 1974-1980) também entrevistado, a relação com a imprensa era, no geral, boa. Segundo Mathes (2014):

sobre os meus seis anos no USIS de São Paulo nos anos de 1970: nós tínhamos uma grande e diversa operação no USIS, quatro americanos na equipe e cerca de trinta brasileiros. Nós disponibilizávamos boletins diários para uma lista de contatos na imprensa, e eu tinha encontros frequentes com editores e repórteres, assim como almoços constantes e jantares sociais na minha casa [...]. Eu me lembro que a equipe e os executivos de "O Estado de S. Paulo" eram os mais difíceis de ver e para se ter um tempo juntos. Folha de São Paulo, Gazeta Mercantil e Veja eram muito mais facilmente acessíveis. Nós também tínhamos muito boas relações com várias estações de rádio, especialmente quando nós podíamos lhes oferecer algumas fitas de música americana, que fossem tocadas no ar. ${ }^{1}$

1 Entrevista por email, em 20 de março de 2014. 
Nos anos Carter (1977-81), a agência chegou a mudar de nome para USICA (United States International Communications Agency) em 1978, assumindo as funções de intercâmbio cultural e educacional levadas anteriormente pelo Departamento de Estado (Tuch, 1990, p.32) e com uma proposta de políticas bidirecionais a longo prazo (ibidem, p.144). No entanto, logo voltou a ter o mesmo perfil anterior da USIA, com Reagan, em 1982.

Apesar do progressivo fechamento de alguns postos locais, como Belém, Fortaleza e Curitiba, por falta de orçamento (ibidem, p.144), e da diminuição das atividades conjuntas com a USAID no Nordeste, continuaram ativas as atividades culturais; como palestras e exposições; e educacionais; principalmente com intercâmbios, aulas de inglês e as bibliotecas nos maiores centros. A fundação Casa de Thomas Jefferson, em Brasília, um dos maiores empreendimentos da USIA nos anos 1970 no Brasil, conseguiu recuperar o investimento feito na sua construção em dois anos, só com o lucro proveniente das aulas de inglês no Centro (ibidem, p.147). ${ }^{2}$

Durante as décadas seguintes, o foco continuava sendo trabalhar com as lideranças da mídia, políticas, comerciais e culturais (Mathes, 2014), principalmente nos grandes centros, como São Paulo, Rio de Janeiro, Brasília, Porto Alegre, Salvador e Recife (Howard, 2014). Tanto Howard - que mencionou palestras pontuais com lideranças do mundo do trabalho e contatos frequentes com o mundo acadêmico - quanto Mathes, que descreveu o trabalho de aproximação de especialistas americanos com universidades brasileiras como a USP, a PUC-SP e a Unicamp, confirmavam a atenção na aproximação com potenciais futuros líderes brasileiros nos anos 1970, 1980 e 1990.

Assim como chegou a auxiliar a libertar um jornalista americano da Time, preso e torturado pela ditadura no Nordeste brasileiro durante os anos 1970 (ibidem), a USIA também ajudou os intelectuais brasileiros perseguidos pela ditadura, como foi o caso de Paul

2 Howard (2014) também menciona o caráter auto-sustentável dos centros binacionais nos anos 70 no Brasil, em grande parte por causa dos cursos de inglês oferecidos. 
Singer, ${ }^{3}$ então professor de Economia e bolsista da Fundação Ford, que após ser detido, foi auxiliado por Joe O’Connel, funcionário da agência no País. Ao saber da prisão, O’Connel mobilizou seus colegas no consulado americano em São Paulo, causando pressão para a libertação do professor junto às autoridades brasileiras. Singer trabalhou no Centro Brasileiro de Análise e Planejamento (Cebrap) e anos depois foi um dos fundadores do Partidos dos Trabalhadores no Brasil e Secretário Nacional de Economia Solidária durante os governos Lula e Dilma.

A aproximação com outros intelectuais do Cebrap também renderam futuros frutos. Mathes mencionou sobre sua boa relação pessoal com Fernando Henrique Cardoso, desde quando esse era pesquisador do Cebrap nos anos 1970. As discussões, muitas vezes acaloradas com o então sociólogo, se refletiram mais tarde, a seu ver, em algumas das ideias e discursos seus como Presidente da República:

Um grupo com quem eu passei um tempo foi o Cebrap (Centro Brasileiro de Pesquisas), e eu tive uma relação muito próxima com o seu chefe acadêmico, Fernando Henrique Cardoso. Nós nos encontramos para almoçar muitas vezes, todos os anos, e conversávamos (às vezes discutíamos) sobre política externa americana e o papel do Brasil no mundo. Eu fiquei muito feliz quando Fernando Henrique foi chamado para Brasília, como ministro das Relações Exteriores, mas realmente feliz quando ele foi eleito Presidente do Brasil alguns anos depois. Ele foi o único Presidente com quem eu tive o tipo de relação de chamar pelo primeiro nome, e eu fiquei muito orgulhoso quando eu ouvi ele incluindo algumas das ideias que discutíamos em seus discursos como Presidente. Eu acho que a presidência de Fernando Henrique foi a mais significativa ao colocar o Brasil em uma postura moderada no mundo moderno. (Mathes, 2014)

3 Ver, Cull (2008, p.339): “Interview: Joe O'Connell, 9 November 1995”. 
Ainda nos anos 1990, quando Fernando Henrique já ocupava o posto de ministro da Fazenda, a USIA ainda envia-lhe livros de economia que poderiam ser de seu interesse, segundo Howard, PAO no Brasil de 1992-1996. Sobre a ocasião, Howard ainda observava que, mais do que nas décadas de 1970 e 1980, teve fortes restrições orçamentárias durante o governo Clinton. Howard, assim como Mathes, sempre salientou que além de relações institucionais, foram importantíssimas as relações pessoais construídas durante suas passagens. Testemunha do ocaso da agência dos anos 1970 aos 1990, Howard, um dos últimos PAOs da era USIA no Brasil, sempre destacou que, sobretudo, era um "labor of love".

Durante os anos Clinton (1993-2001), ao mesmo tempo em que a agência sofria sérios cortes orçamentários, o papel da USIA começou a ser repensado para além das relações culturais e informacionais tradicionais, discutindo-se, de acordo com os moldes propostos por Hansen nos anos 1980, ${ }^{4}$ a adaptação dos trabalhos de informação às novas tecnologias.

$\mathrm{Na}$ ocasião, chegou a ser proposto o trabalho da USIA levando-se em consideração a possibilidade de criação de uma rede mundial de informação. O projeto, no entanto, não teria sido levado adiante pela falta de capacidade de infraestrutura para implementação das novas ideias:

A agência estava movimentando-se para criar "uma rede mundial eletrônica e humana de informações, explorando a tecnologia de compressão digital que agora apareceu no mercado com as linhas de transmissão de informação de alta velocidade". No entanto, alguns operadores estavam impacientes com a reformulação que eles achavam ser somente retórica: Há um tipo de visão nessa administração sobre a "via eletrônica de alta velocidade". Existe

4 "Public Diplomacy in the Computer Age", é obra pioneira sobre as possibilidades de ação da USIA considerando-se as novas tecnologias de informação. Nesse estudo, Hansen (1984, p.225) propunha uma nova postura da agência, incluindo a tecnologia e a computação como instrumentos.

5 "eletronic highway". 
muito "falatório". ${ }^{6}$ Mas a infraestrutura para o seu manejo é muito precária. (Bogart, 1995, p.xxvii)

Os sucessivos cortes orçamentários e falta de capacidade de ação e estrutura fez com que a agência enfrentasse formalmente seu fim no ano de 1999, ainda no governo Clinton. Muitas de suas atribuições restantes foram assimiladas principalmente pelo Departamento de Estado.

À primeira vista, a história mostra ser direta a associação entre a USIA e a Guerra Fria; pelo contexto que motivou sua criação, pelos perfis e conteúdos de suas ações, pelos argumentos para o aumento (ou diminuição) de seu orçamento, pessoal, e também por seu declínio, que se acirrou à medida que a Guerra Fria ia congelando. No Brasil, esse declínio (de orçamento, pessoal e atividades) também foi observado à medida em que o risco comunista se afastava.

A crise interna vivida pelos EUA durante a guerra do Vietnã, ${ }^{7}$ bem como a sua imagem externa, também foram resultado direto da falta de prioridade que o País deixou de ter com a política de informação, conjuntamente com outros erros estratégicos. ${ }^{8}$ Mas seguramente os resultados positivos que os EUA deixaram de ter ao não dar o devido valor para a USIA, ao longo, principalmente dos anos 1980 e 1990, foram e continuam sendo sentidos no pós-Guerra Fria.

Nesse sentido, o valor dado ao tipo de trabalho feito pela USIA não deve estar ligado somente à Guerra Fria, assim como o CPI de Creel, à época, não deveria só ser visto como arma americana da $1^{\text {a }}$ Guerra, e o Birô de Rockefeller, atrelado à $2^{\text {a }}$ Guerra. Mesmo sendo deixados de lado, após passadas as crises que motivaram suas

6 "buzz words".

7 Nye (2004, p.3) vê o exemplo da guerra do Vietnã como descuido no uso do soft power, que é decisivo na batalha, mesmo quando há maior poderio militar e econômico.

8 Os possíveis erros de percepção em relação ao Vietnã e ao caráter mais nacionalista do que propriamente comunista que movia o país naquela ocasião, é discutido no documentário "The Fog of War" (2001), sobre o ex-secretário de Defesa norte-americano, Robert Mcnamara (das gestões JFK e Johnson). 
criações, os reflexos de suas políticas continuaram tendo efeito a médio e longo prazo.

A retomada de políticas de informação e cultural consistentes compatíveis com os interesses da política externa americana, como as já pensadas e realizadas com sucesso em algumas ocasiões ao longo da história dos EUA - ainda é reinvidicada internamente por alguns grupos, como instrumento acessório de curto, médio e longo prazo; como forma de qualificar a sua política externa, em momentos de guerra e de paz.

Como o Council on Foreign Relations (2003, p.48) sugeriu após o atentado às Torres Gêmeas e durante a segunda Guerra do Iraque, em 2003:

Afinal, os Estados Unidos agiu destacadamente abaixo do esperado em seus esforços para conquistar corações e mentes de públicos estrangeiros. A marginalização da diplomacia pública deixou um legado de esforços descoordenados e subfinanciados. A falta de vontade política e a ausência de uma estratégia global deixaram os antigos programas de diplomacia pública praticamente impotentes no crescentemente abarrotado mundo das comunicações atual. Mesmo que uma diplomacia pública potente não seja a bala de prata para os problemas de imagem americanos, torná-la um componente relevante do processo de formação da política externa é um passo vital para garantir a segurança nacional.

Entre outras coisas, o que pôde ser notado ao longo dessa pesquisa, foi que os EUA utilizaram esses instrumentos em momentos de conflitos mais críticos, como as duas grandes Guerras e a Guerra Fria. Quando o País estava em maior risco, escolheu estruturar-se de maneira que a opinião pública estrangeira fosse monitorada e tomou iniciativas para mudá-la em seu favor.

9 O Council é um órgão não-governamental criado em 1921, que reúne diversos atores e setores para discutir e propor ações para a política externa americana. Mais informações sobre o Council, disponível em < http:/ /www.cfr.org > Acesso em: 22 dez. 2014. 
É interessante também destacar que a decisão por utilizar a arma da informação deu-se com ambos os partidos americanos: os democratas (Wilson e Roosevelt) e os republicanos (Eisenhower). Por outro lado, a dissolução dos órgãos responsáveis pela informação sempre aconteceu em momentos de "paz" e em governos do partido democrata.

A USIA, o órgão que chegou a ter maior número de funcionários no exterior, orçamento e volume de atividades durante o maior período de tempo (46 anos), foi a iniciativa mais bem sucedida entre as formas de propaganda americana durante o século XX. E a ação dela no Brasil foi maciça e teve reflexos concretos na mídia nacional: rádio, cinema, TV, jornais, revistas e materiais gráficos, durante todo o período.

Além disso, o trabalho direto da USIA por meio de seus centros binacionais, postos móveis, ensino de inglês, bibliotecas e da relação pessoal alimentada com lideranças políticas, educacionais e formadores de opinião pública teve reflexo no perfil da opinião brasileira, majoritariamente favorável à americana, principalmente na segunda metade do século XX.

É possível afirmar, com base na documentação levantada, que o esforço americano de informação no Brasil visou influenciar, decisivamente, os humores políticos da população em geral, e de grupos prioritários em particular, em momentos críticos da história brasileira recente, como nos anos que antecederam o Golpe Civil-Militar de 1964.

Considerando a recorrência histórica dos EUA em criar novos instrumentos e instituições para continuar atingindo a opinião pública estrangeira de maneira não declarada, e a permanência de muitos dos principais grupos da mídia brasileira, ainda hoje é necessário tentar desnaturalizar esses processos pelos quais ainda pode passar o Brasil - receptor de fluxos culturais internacionais - muitas vezes provenientes de políticas de propaganda de Estados estrangeiros, mas que também podem se expressar por intermédio de atores da sociedade civil e outros atores não-governamentais.

Reconhecidos esses aspectos, há da mesma maneira a necessidade de pensar o Brasil não somente como receptor de políticas 
culturais estrangeiras, usadas como instrumentos de poder, mas também como possível produtor de políticas culturais e informacionais que podem auxiliar o país na consecução de seus interesses de política externa, seja na integração regional ou nas relações entre países do Sul, mas também nas relações tradicionais com países tidos como "desenvolvidos".

A forma como o Brasil pode utilizar-se de suas manifestações culturais, educacionais ou de comunicação no exterior faz parte de um projeto de País mais sofisticado e eficiente, a ser pensado pelos seus cidadãos, pesquisadores e atores das Relações Internacionais. 


\section{REFERÊNCIAS BIBLIOGRÁFICAS}

ABREU PENNA, L. de. Manifestos políticos do Brasil contemporâneo. Rio de Janeiro: E-papers, 2008.

ALKER, H.; BIERSTEKER, T. The Dialectics of World Order: notes for a future archeologist of International Savoir Faire, International Studies Quarterly, v.28, p.121-42, 1984.

ALMOND, G.; GENCO, S. Clouds, Clocks, and the Study of Politics, World Politics, v.29, n.4, p.489-522, 1977.

ALVES, J. F. A invasão cultural norte-americana. São Paulo: Moderna, 1988.

APPY, C. G (ed.). Cold War Constructions. The Political Culture of United States Imperialism: 1945-1966. Massachusetts: The University of Massachusetts Press, 2000.

ARNDT, RICHARD T. The first resort of kings - American cultural diplomacy in the twentieth century. Washington D.C.: Potomac Books, 2005.

ARON, Raymond. Qu'est-ce que qu'une théorie des Relations Internationales. Paris: RFSP, 1967. Peace and War. New York: Praeger, 1968.

ASHLEY, R. K. "The poverty of neorealism”. In: KEOHANE, R.O. (ed.). Neorealism and its critics. New York: Columbia University Press, 1986.

BANDEIRA, M. Presença dos Estados Unidos no Brasil (dois séculos de história).

Rio de Janeiro: Civilização Brasileira, 1973.

BELTRÁN, L. R.; CARMONA, E. F. de. Comunicação dominada: os Estados Unidos e os meios de comunicação na América Latina. Rio de Janeiro: Paz e Terra, 1982. 
BEMIS, S. F. The Latin American policy of the United States: an historical interpretation. Nova York: Harcourt, Brace and Company, 1943.

BINKLEY, W. E. Partidos políticos americanos. v.1 e 2. Rio de Janeiro: Fundo de Cultura, 1961.

BLACK, J. K. United States penetration of Brazil. Philadelphia: University of Pennsylvania Press, 1977.

BLEIKER, R. The Aesthetic Turn in International Political Theory. Millennium - Journal of International Studies, v.30, n.3, 2001, p.509-33.

BOGART, L. Cool Words, Cold War: a new look at USIA's Premises for propaganda. Washington, D.C.: The American University Press, 1995.

BOURDIEU, P. Dois imperialismos do Universal. In: Repensar os Estados Unidos: por uma sociologia do superpoder. São Paulo: Papirus Editora, 2003.

BRAISTED, P. J. Cultural affairs and foreign relations. Washington D.C.: Columbia Book Publishers, 1968.

BRECHER, M. International studies in the twentieth century and beyond: flawed, dichotomies, synthesis, cumulation. International Studies Quarterly, v.43, p.213-64, 1999.

BROCKMANN, M. M. Notas sobre política cultural no Brasil. In: MICELI,

S. Estado e cultura no Brasil. São Paulo: Difel/Difusão Editorial, 1984.

BUARQUE DE HOLANDA, S. Considerações sobre o americanismo. In: Cobra de vidro. São Paulo: Perspectiva, 1978.

. Visão do paraíso. São Paulo: Brasiliense, 2000.

. Raízes do Brasil. São Paulo: Companhia das Letras, 1995.

BUZAN, B.; LITLLE, R. Why International Relations has Failed as an Intellectual Project and what to do about that, Millennium - Journal of International Studies, v.30, n.1, p.19-39, 2001.

CABRAL, S. Antônio Carlos Jobim - uma biografia. Rio de Janeiro: Lumiar, 1997.

CATTAI, J. B. P. O estandarte silencioso: a United States Information Agency na mídia impressa do Brasil - Correio da Manhã e Tribuna da Imprensa, 1953-64. São Paulo, 2011. Dissertação (Mestrado) - Universidade de São Paulo.

CAZES, H. Choro - do quintal ao municipal. São Paulo: Editora 34, 1998.

CAUTE, D. The Dancer Defects - The struggle for Cultural Supremacy during the Cold War. Oxford: Oxford University Press, 2003.

CHARTIER, R. A história cultural. Lisboa: Difel, 1990.

. Au bord de la falaise, l'histoire entre certitudes et inquiétudes. Paris: Albin Michel, 1998. 
CHEKEL, J. The Constructivist Turn in International Relations Theory. World Politics, v.50, n.2, p.324-48, 1998.

CHESNOFF, R. Z. The arrogance of the French: why they can't stand us and why the feeling is mutual. New York: Penguin Books, 2006.

CHOMSKY, N. The Pentagon Papers as propaganda and as history. New York: Beacon Press, 1972.

CICCO, C. Hollywood na cultura brasileira. São Paulo: Convívio, 1979.

COBBS, E. A. The rich neighbor policy: Rockefeller and Kaiser in Brazil. New Haven: Yale University, 1992.

COELHO, T. Dicionário Crítico de Política Cultural. São Paulo: Iluminuras, 1999.

COLBY, G.; DENNETT, C. Seja feita a vossa vontade: a conquista da Amazônia - Nelson Rockfeller e o evangelismo na idade do Petróleo. Rio de Janeiro: Record, 1998.

COLLIEN, M. Foreign Policy in a Constructed World. New York: Sharpe, 2000.

COOMBS, P. H. The Fourth Dimension of Foreign Policy. Nova York: Harper \& Row Publishers, 1964.

COX, R. W.; SINCLAIR, T. J. Approaches to world order. Cambridge: Cambridge University Press, 1999.

. Social forces, States and World Orders: beyond international relations theory. In: KEOHANE, R. O. (ed.). Neorealism and its critics. New York: Columbia University Press, 1986.

COX, R. W.; SINCLAIR, T. J. Approaches to world order. Cambridge: Cambridge University Press, 2001.

COX, R. W. Gramsci, materialismo histórico e relações internacionais. Rio de Janeiro: Editora da UFRJ, 2007.

COUNCIL ON FOREIGN RELATIONS. Finding America's Voice: A Strategy for Reinvigorating U.S. Public Diplomacy. New York: Publications Office of the Council on Foreign Relations, 2003.

CREEL, G. How we advertised America. New York and London: Harper \& Brothers Publishers, 1920a.

. The War, The World And Wilson. New York and London: Harper \& Brothers Publishers, 1920b.

CULL, N. J. The Cold War and the United States Information Agency: American propaganda and public diplomacy. 1945-1989. New York: Cambridge University Press, 2008.

DARBY, P. Pursuing the Political: a Postcolonial Rethinking of Relations International. Millennium -Journal of International Studies, v.33, n.1, p.1-32, 2004. 
DE CONDE, A. Herbert Hoover's Latin American Policy. Stanford: Stanford University Press, 1951.

DIZARD JR., W. P. Inventing Public Diplomacy: the story of the U.S. Information Agency. London: Lynne Rienner Publishers, 2004.

DUNER, B. Cultural dimensions of dependency: the Interamerican system. Uppsala: Uppsala University, 1973.

DUROSELLE, J.-B., Culture et relations internationales. Relations Internationales. Paris: 24, 1980 \& 25, 1981.

ELDER, R. E. The information machine: The United states Information Agency and American foreign policy. Nova York: Siracuse University press, 1968.

FEJES, F. Imperialism, media and Good Neighbor: New Deal foreign policy and United States short-wave broadcasting to Latin American. Nova Jersey: Ablex Publishing Corporation, 1986.

FRANKEL, C. The Neglected Aspect of Foreign Affairs-American Educational and Cultural Policy Abroad. Washington, D. C.: The Brookings Institution, 1965.

FREITAS, Z. Lutas camponesas no Cabo. In: SIMPÓSIO NACIONAL DE HISTÓRIA, 23, Londrina, 2005. Anais do XXIII Simpósio Nacional de História - História: guerra e paz. Londrina: ANPUH, 2005. CD-ROM.

FURTADO, C. A hegemonia dos Estados Unidos e o subdesenvolvimento da América Latina. Rio de Janeiro: Civilização Brasileira, 1973.

Política cultural. Pronunciamento realizado na Escola Superior de Guerra. Brasília: documento MinC3/86, 14 p, 03 set. 86.

GELLMAN, I. F. Good Neighbor diplomacy: United States policies in Latin America, 1933-1945. Baltimore: Johns Hopkins University, 1979.

GILBAUT, S. How New York stole the Idea of Modern art. Chicago: University of Chicago Press, 1983.

GOWAN, P. "A radical realist". New Left Review, London, n.41, Second Series, sep.-oct. 2006.

GRIFFITS, M. 50 Grandes estrategistas das relações internacionais. São Paulo: Contexto, 2004.

GREEN, F. American Propaganda abroad. Nova York: Hipocreene Books, 1988. GUEDES, C.; MELO, M. F. de. O caso dos nove chineses: o escândalo internacional que transformou vítimas da ditadura militar brasileira em heróis de Mao Tsé-Tung. Rio de Janeiro: Objetiva, 2014.

GUINLE, J. E. Panorama Jazz. Rio de Janeiro: José Olympio, 2002.

GUZZINI, S. A Reconstruction of Constructivism in International Relations. European Journal of International Relations, v.6, n.2, 2000, p.147-82.

HAINES, G. K. The Americanization of Brazil: a study of U.S. cold war diplomacy in the Third World. Wilmington: SR Books, 1989. 
HALIDAY, F. International Relations and Its Discontents. International Affairs, v.71, n.4, p.733-46, 1995.

HAMILTON; MADISON; JAY. Sobre a Constituição dos Estados Unidos. São Paulo: Ibrasa, 1964.

HANSEN, A. C. USIA, public diplomacy in the computer age. New York: Praeger, 1984.

HARDT, M; NEGRI, A. Império. Rio de Janeiro: Editora Record, 2001.

HENDERSON, J. W. The United States Information Agency. New York: Praeger Library of U.S. Government Departments and Agencies, 1969.

MAY, H.; SELLERS, C.; MCMILLEN, N. R. Uma reavaliação da história dos Estados Unidos. Rio de Janeiro: Jorge Zahar, 1990.

HERZ, M. Zé Carioca: o embaixador de duas caras. Rio de Janeiro, 1986. Dissertação (Mestrado) - Instituto Universitário de Pesquisas do Rio de Janeiro.

A dimensão cultural das relações internacionais: proposta teórico-metodológica. Contexto Internacional, v.6, jul. 1987.

HIXSON, W. L. Parting the curtain: propaganda, culture and the Cold War, 1945-1961. New York: St. Martin's Press, 1997.

HOBBES, T. O Leviatã. São Paulo: Abril Cultural, 1979 (Os Pensadores).

HOBSBAWN, E. O novo século: entrevista a Antônio Polito. São Paulo: Companhia das Letras, 2000.

. História social do jazz. São Paulo: Paz e Terra, 2002.

HOFFMANN, s. International Relations: The Long Road to Theory. World Politics, v.11, n.3, 1959, p.346-77.

HOPF, T. The promise of Constructivism in International Relations Theory. Ohio: Massachusetts Institute of Technology, 1998.

HORKHEIMER, M.; ADORNO, T. W. Dialética do esclarecimento. Rio de Janeiro: Jorge Zahar, 1985.

HOROWITZ, I. L. The Rise and Fall of Project Camelot: Studies and Relationship between Social Science and Practical Politics. Cambridge, Massachusetts: M.I.T. Press, 1967.

HOUSE OF COMMONS. Foreign Affairs Committee, Fourth Report: Cultural Diplomacy, sessions 1986/87.

HOWARD, C. Entrevista [mensagem de correio eletrônico]. Mensagem recebida por <fsantomauro@gmail.com>.em 17 mar. 2014.

HUDSON, V.; BOER, A. A Surplus of Men, A Deficit of Peace Security and Sex Ratios in Asia's Largest States. International Security, v.26, n.4, p.5-38, 2002.

HUNTINGTON, S. P. A ordem política nas sociedades em mudança. São Paulo: Edusp, 1975. 
.; HARRISON, L. E. (orgs.). A cultura importa. São Paulo: Contexto, 2002.

The Clash of Civilizations and the Remaking of World Order. New York: Touchstone, 1996.

IANNI, O. Imperialismo e cultura. Petrópolis: Vozes, 1979.

JONES, K. D. Hollywood at War: the American motion picture and the World War II. South Brunswick: A. S. Barnes, 1973.

Katzenstein, P KEOHANE, R.; Krasner, S. International Organization and the Study of World Politics. International Organization, v.52, n.4, p.645-85, 1998.

KEATING, M.; DELLA PORTA, D. In Defense of Pluralism in the Social Sciences. European Political Science, n.9, 2010.

Keohane, R. O., Martin, L. L. The Promise of Institutionalist Theory. International Security, v.20, n.1, p.39-51, 1995.

KISSINGER, H. Diplomacy. New York: Touchstone Edition, 1995.

The White House Years. Boston: Little, Brown and Company, 1979.

LAFER, C. A identidade internacional do Brasil e a Politica Externa Brasileira. São Paulo: Perspectiva, 2001.

LAPID, Y. The Third Debate: On the Prospects of International Theory in a Post-Positivist Era, International Studies Quarterly, v.33, n.3, p.235-54, 1989.

LAVINE, H. War propaganda and the United States. New Haven: Yale University Press, 1940.

LEE, M.; MCMURRY, R. E. The Cultural Approach. North Carolina: The University of North Carolina Press, 1947.

LIMA, J. L. A expressão americana. São Paulo: Brasiliense, 1988.

LIMA, O. Formação histórica da nacionalidade brasileira. São Paulo: Brasiliense, 2000.

LOBATO, M. América. São Paulo: Brasiliense, 1959.

LOWENTHAL, A. F. Os Estados Unidos e a América Latina na virada do século. Revista de Política Externa, v.9, n.3, 2001.

MANDELBAUM, M. The ideas that conquered the world: Peace, Democracy and Free Markets in the Twenty-first Century New York: Public Affairs, 2003.

. The case for Goliath: How America act as the world's Government in the 21st Century, New York: Public Affairs, 2005.

MAQUIAVEL, N. O Príncipe. São Paulo: Abril Cultural, 1979. (Os Pensadores).

MARINI, R. M. América Latina. Dependência e Integração. São Paulo: Página Aberta, 1992. 
MÁRMORA, L. El concepto socialista de nación. México: Ediciones Pasado y Presente, 1986.

MARTÍ, J. Nossa América. São Paulo: Hucitec, 1983.

MATHES, D. Entrevista [mensagem de correio eletrônico]. Mensagem recebida por <fsantomauro@gmail.com>.em 15 mar. 2014.

MATTERLAT, A. Multinacionais e sistemas de comunicação. São Paulo: Ciências Humanas, 1976.

MATTHIEAU, G. Une ambition sud-américaine: Politique Culturelle de la France (1914-1940). Paris: L'Harmattan, 1991.

Mearsheimer, J. J. The False Promise of International Institutions. International Security, v.19, n.3, p.5-49, 1994.

MELLO, Z. H. de M.; SEVERIANO, J. A canção no tempo - 85 anos de músicas brasileiras. v.1 e 2. São Paulo: Editora 34, 1997.

McMURRY, R.; LEE, M. The cultural approach, an other way in international relations. North Carolina: University of North Carolina Press, 1947.

MICELLI, S. Les intellectuels et le pouvoir au Brésil (1920-1945). Paris: MSH, 1981.

MITCHELL, J. M. International Cultural Relations. London: Allen \& Unwin, 1986.

MORETTI, F. Planet Hollywood. New Left Review, n.9, jun. 2001.

MORSE, R. M. O espelho próspero: cultura e idéias nas Américas. São Paulo: Companhia das Letras, 1986.

MOURA, G. Tio Sam chega ao Brasil, A penetração cultural norte-americana. São Paulo: Brasiliense, 1985.

; KRAMER, P. Brasil-EUA: as razões das diferenças. Revista Ciências Sociais Hoje, São Paulo, 1987.

MURPHY, C. N. International Organization and Industrial change. Global Governance since 1850. Cambridge: Polity Press, 1994.

NICHOLS, D. A. Eisenhower 1956: the president's year of crisis: Suez and the brink of war. New York: Simon \& Schuster, 2011.

NINKOVICH, F. A. The diplomacy of ideas: US foreign policy and cultural relations, 1938-1950. 1.ed. Cambridge: Cambridge University Press, 1981. NYE, J. The Paradox of American Power: Why the World's Only Superpower Can't Go It Alone. Oxford: Oxford University Press, 2002.

NYE, J. The Powers to Lead. Oxford University Press, 2008.

. Bound to Lead: The Changing Nature of American Power. New York: Basic Books, 1991.

Soft power. New York: Public Affairs, 2004.

ONUF, N. Institutions, Intentions and International Relations. Review of International Studies, v.28, n.2, p.211-28, 2002. 
OSGOOD, K. Total Cold War, Eisenhower's Secret Propaganda Battle at Home and Abroad. Kansas: University Press of Kansas, 2006.

PARSONS, A. Vultures and Philistines: British attitudes to culture and cultural diplomacy. British Council, 1985.

PETRAS, J.; VELTMEYER, H. Hegemonia dos Estados Unidos no novo milênio. Petrópolis: Vozes, 2000.

PELLS, R. Not like us: How Europeans have loved, hated and transformed American Culture since World War II. New York: Basic Books, 1997.

PREVOTS, N. Dance for Export: Cultural Diplomacy and the ColdWar. Middletown: Wesleyan University Press, 1998.

REICH, C. The Life of Nelson A. Rockefeller: worlds to conquer, 1908-1958. New York: Doubleday, 1996.

RIGAUD, J. Les Relations Culturelles Extérieures. Paris: La Documentation Française. 1980.

RIBEIRO, E. T. Diplomacia Cultural: seu papel na política externa brasileira. Brasília: Fundação Alexandre Gusmão, 1989.

ROLLAND, D. La crise du modèle français: Marianne et l'Amérique latineculture, politique et identité. Paris: L'Harmattan, 2000.

ROLO, C. J. Radio goes to war. New York: G.P. Putnan's Sons, 1942.

ROSENBERG, J. The empire of civil society. A critique of the realist theory of international relations. London: Verso, 1994.

ROWLAND, D. W. (dir.). History of the Office of the Coordinator of Inter-American Affairs - historical report on war administration. Washington D. C., U.S. Government Printing Office, 1947.

SAHLINS, M. Ilhas da História. Rio de Janeiro: Zahar, 1990.

SANTOMAURO, F. As Políticas culturais de França e Estados Unidos no Brasil no entreguerras. São Paulo, 2007. Dissertação (Mestrado) - Pontifícia Universidade Católica.

De Brésil to Brazil - A política cultural como instrumento de poder: os casos de França e Estados Unidos no Brasil na primeira metade do século XX. In: SUPPO, H. R.; LESSA, M. L. (Org.). A quarta dimensão das relações internacionais: a dimensão cultural. Rio de Janeiro: Contra Capa, 2012a.

O velhinho gigante. Revista Inter-relações, São Paulo, p.17-20, 2012b. . Autonomia diante dos EUA é comunismo ou bolivarianismo? Uma carta escrita por um analista norte-americano em 1964 mostra que, há décadas, os estereótipos limitam as relações entre Washington e Brasília. Disponível em: <http://www.cartacapital.com.br/blogs/blog-do-grri/dicas-de-dr-wedge-para-dilma-e-os-estados-unidos-6001.html>. Acesso em: 2 nov. 2014. 
SAUNDERS, F. S. The Cultural Cold War: The CIA and the World of Arts and Letter. USA: New Press, 2000.

SCHLESINGER JR., A. M. Os ciclos da história Americana. Rio de Janeiro: Civilização Brasileira, 1992.

SCHOULTZ, L. Estados Unidos: poder e submissão, uma história da política norte-americana em relação à América Latina. São Paulo: Edusc, 2000.

Schroeder, P. Historical Reality vs. Neo-Realist Theory. International Security, v.19, n.1, p.108-48, 1994.

SCHWARTZ, J. Vanguardas latino-americanas: polêmicas, manifestos e textos críticos. São Paulo: Edusp, 2000.

SELLERS, C.; MAY, H.; MCMILLEN, N. R. Uma reavaliação da história dos Estados Unidos: de colônia a potência imperial. Rio de Janeiro: Zahar, 1990.

SMITH, J. Unequal giants: diplomatic relations between the United States and Brazil, 1889-1930. Pittsburgh: University of Pittsburgh, 1991.

SOLEY, L. C. Radio Warfare: OSS and CIA subversive propaganda. Nova York: Praeger, 1989.

SORENSEN, T. C. The world war: the story of American propaganda. Nova York: Harper \& Row, 1968.

STENSSORO, H. De caso com a CIA. Revista República, ago. 2000.

STUART, A. M. Regionalismo e democracia: uma construção possível. São Paulo, 2002. Tese (Doutorado) - Universidade de São Paulo.

SUPPO, H. R.; LESSA, M. L. A quarta dimensão das relações internacionais: a dimensão cultural. Rio de Janeiro: Contra Capa, 2012.

. Le Brésil pour la France: la construction d'une politique culturelle française 1920-1950. In : ROLLAND, D. Le Brésil et le monde. Pour une histoire des relations internationales des puissances émergentes. Paris: L'Harmattan, 1998.

TICKNER, J. You Just Don't Understand: Troubled Engagements between Feminists and IR Theorists. International Studies Quarterly, v.41, n.4, p.611-32, 1997.

TOCQUEVILlE, A. de. A democracia na América. São Paulo/Belo Horizonte: Edusp/Itatiaia, 1977.

TOTA, A. P. O imperialismo sedutor. São Paulo: Companhia das Letras, 2000. Cultura e dominação: relações culturais entre o Brasil e os Estados Unidos durante a Guerra Fria. Revista Perspectivas, São Paulo. 2005.

TYSON, J. L. Us International broadcasting and national security. Nova York, Ramapo Press/National Security Information Center, 1983.

TUCH, H. N. Communicating with the world: U.S. public diplomacy overseas. New York: St. Martin’s Press, 1990. 
VERÍSSIMO, É. Gato preto em campo de neve. Porto Alegre: Globo, 1984.

VIANA, F. Antropofagia e Globalização. São Paulo: Fundação Memorial da América Latina, 2002.

VIANA FILHO, L. A vida do Barão de Rio Branco. Rio de Janeiro: José Olympio, 1988.

VIANNA, H. O mistério do samba. Rio de Janeiro: Zahar, 2002.

VIGEVANI, T. História e contemporaneidade na questão nacional. In: BRESCIANI, M. S.; SAMARA, E. de M.; LEWKOWICZ, I. Jogos da política. São Paulo: ANPUH/Marco Zero/Fapesp, 1992.

. et al. A contribuição marxista para o estudo das relações internacionais. Lua Nova, n.83, p.111-43, 2011.

VIRILLO, P. Guerra e cinema. São Paulo: Scitta, 1993.

VON ESCHEN, Penny M. Satchmo blows up the world, Jazz Ambassadors Play the Cold War. Cambridge: Harvard University Press, 2004.

WALKER, R. B. J. Realism, Change and International Political Theory. International Studies Quarterly, n.31, v.1, p.65-86.

WALLERSTEIN, I. El moderno sistema mundial. México: Siglo Veintiuno Editores, 1979.

O declínio do império americano. New York Times, Nova Iorque, 8 ago. 2003.

WALTZ, K. Structural Realism after the Cold War. International Security, v. 25, n.1, p.5-41, 2000.

WEBER, M. Os três tipos de dominação legítima. In: WEBER, M. Sociologia. São Paulo: Ática, 1979 (Coleção Grandes Cientistas Sociais).

. A ética protestante e o espírito do capitalismo. São Paulo: Pioneira, 1999.

WENDT, A. The Agent-Structure Problem in International Relations. International Organization, v.41, n.3, p.335-70, 1987.

. Driving with the Rearview Mirror: On the Rational Science of Institutional Design. International Organization, v.55, n.4, p.1019-49, 2001.

WILFORD, H. The mighty Wurlitzer. How the CIA played America. Cambridge: Harvard University Press, 2008.

WINKLER, A. M. The politics of propaganda: the office of war information, 1942-1945. New Haven: Yale University Press, 1978.

WOLPER, G. The Origins of Public Diplomacy: Woodrow Wilson, George Creel, and the Committee on Public Information. Chicago, 1991. Dissertação (Ph.D.) - University of Chicago.

YETIV, S. History, International Relations, and Integrated Approaches: Thinking about Greater Interdisciplinary. International Studies Perspectives, n.12, 94-118, 2011. 


\section{Referências documentais utilizadas}

Documento 1: Johnson Library, Recordings and Transcripts, Tape F64.21, Side B, PNO1, Office of Historian, US Department of State, em Historical Documents, Foreign Relations of the United States, 1964-1968, Volume XXXI, South and Central America; Mexico, Document 193. Telephone Conversation Between Secretary of State, Rusk and President Johnson. March 30, 1964, 9:35 p.m., disponível em <http://history.state.gov/historicaldocuments/ frus1964-68v31/d193>. Acesso em: 28 nov. 2013.

Documento 2: Memorandum for the record by FitzGerald, March 31; Central Intelligence Agency, Job 78-03041R, [file name not declassified]). Disponível em: <http://history.state.gov/historicaldocuments/frus1964-68v31/ d193>. Acesso em: 28 nov. 2013.

Documento 3: National Archives and Records Administration, RG 59, Central Files 1964-66, POL 23-9 BRAZ. Top Secret; Flash; Nodis. Drafted and approved by Rusk. Office of the Historian, Foreign Relations of the United States, 1964-1968, Volume XXXI, South and Central America; Mexico, Document 194. Disponível em: <http://history.state.gov/historicaldocuments/frus1964-68v31/d194>. Acesso em: 27 nov. 2013.

Documento 4: Johnson Library, Recordings and Transcripts, Recording of telephone conversation among President Johnson, Ball and Mann, Tape F64.21, Side B, PNO 3. No classification marking. Ball and Mann were in Washington; the President was in Texas", e citada no site Office of the Historian, Department of State, FOREIGN RELATIONS OF THE UNITE”D STATES, 1964-1968 VOLUME XXXI, SOUTH AND CENTRAL AMERICA; MEXICO, DOCUMENT 199. Disponível em: <http://history.state.gov/historicaldocuments/frus1964-68v31/d199>. Acesso em: 27 nov. 2013.

Documento 5: Johnson Library, National Security File, Country File, Brazil, Vol. II, 3/64;

Documento 6: Johnson Library, Recordings and Transcripts, Recording of telephone conversation between President Johnson and Richard Russell, Tape F64.16, Side B, PNO 3. No classification marking, Office of the Historian, Department of State, FOREIGN RELATIONS OF THE UNITED STATES, 1964-1968 VOLUME XXXI, SOUTH AND CENTRAL AMERICA; MEXICO, DOCUMENT 396. Disponível em: <https://history.state.gov/ historicaldocuments/frus1964-68v31/d396>. Acesso em: 27 nov. 2013.

Documento 7: Telegram 1299 to Rio de Janeiro, March 31; National Archives and Records Administration, RG 59, Central Files 1964-66, POL 2 BRAZ; 
Documento 8: Johnson Library, National Security File, Country File, Brazil, Vol. II, 3/64. Secret; Exdis. According to Rusk's Appointment Book, Rusk met Ball and U. Alexis Johnson at 10 a.m. for the teleconference to Rio". Office of the Historian, Department of State, FOREIGN RELATIONS OF THE UNITED STATES, 1964-1968 VOLUME XXXI, SOUTH AND CENTRAL AMERICA; MEXICO, DOCUMENT 201, Teleconference Between the Department of State and the Embassy in Brazil. Disponível em: <http:// history.state.gov/historicaldocuments/frus1964-68v31/d201>. Acesso em: 28 nov. 2013.

Documento 9: Office of the Historian, do Departamento do Estado. Telegram 2126 from Rio de Janeiro, March 31; ibid., POL 23-9 BRAZ. Teleconference Between the Department of State and the Embassy in Brazil. Disponível em: <http://history.state.gov/historicaldocuments/frus1964-68v31/d201>. Acesso em: 28 nov. 2013.

Documento 10: National Archives and Records Administration, College Park, Nara II, RG 306, Declassified NND 022120, RECORDS OF THE UNITED STATES INFORMATION AGENCY (USIA); Movie Scripts, 19421965; Stack area 230, Row 047, compartment 17, Shelf 1-7, Entry A1-1098, Box 48, Script of the movie "Victory for Democracy in Brazil", 15/5/1964.

Documento 11: Nara II, RG 306, Declassified NND 931588, Records of the United States Information Agency, Exhibits Division, Subject Files of the Director, 1959-67, ICS/Director - Correspondence to IAN (Near East) correspondence, Stack area 230, Row 046, compartment 030, Shelf 07, Entry A1-1038, Box 1, HM 1991, "Memorandum for Mr. Akers, Subject ICS - Type Activities re Possible CBS Show, p.2, October 8,1965", "Manpower utilization, apr./may 1964", "Exhibits Division Working Relationships with CU”.

Documento 12: Nara II, RG 306, Declassified NND 988085, Records of the United States Information Agency, Office of Research, Area Project Correspondence, 1954-1963; Latin America 1954-63, Stack area 230, Row 046, compartment 035, Shelf 04, Entry A1-1021, Box 2. Operations memorandum, Oct. 4, 1963 (French Government Interest in Latin American Information Campaign). From USIS-Montevideo To: USIA-Washington (IRS); "Institutos de Pesquisa contratados para Barometer/1955", "Latin American Barometer, LA-6", "Impact of the Cooper Space Flight in Rio de Janeiro", "USIA/IRS/R/ TV Survey in São Paulo May, 1963”.

Documento 13: Walter Clinton Jackson Library, The University of North Carolina at Greensboro, Special Collections E Rare Books, WORLD WAR I PAMPHLET COLLECTION, Issued by the Committee on Public 
Information, The Secretary of State, The Secretary of War, The Secretary of Navy, George Creel, edition of January 1918. Disponível em: <https:// ia600305.us.archive.org/10/items/howwarcametoamer00unse/howwarcametoamer00unse.pdf > . Acesso em: 26 nov. 2013.

Documento 14: Nara II, RG 306, Declassified NN3-306-02-003, General Records of the United States Information Agency, Office of Administration; Historical Collection, Murray Lawson History Card Files Series; 1953-1975, State OIE/OII-OEX, 1945-1953 to State OIE/OII-OEX, 1945-1953, Stack area 230, Row 047, compartment 26, Shelf 6, Entry A1-1055, Box 14. 1945-58: Statistics on U.S. Financial Aid to BNCs in Latin America, HAC, USIA Approp '58, p.296-7 (5 Mar 57), 1946: Statistics on Cost of U.S. Support of Cultural Centers in Latin America; 1945-46: Cultural Centers in Latin America, DSB, 14 (17 Feb 46) 227-232-262, "Cultural Centers in the Other American Republics", article by Dorothy Greene and Sherly Goodman Esman.

Documento 15: Nara II, RG 306, Declassified NN3-306-02-003, General Records of the United States Information Agency, Office of Administration; Historical Collection, Murray Lawson History Card Files Series; 1953-1975, State OIE/OII-OEX, 1945-1953 to State OIE/OII-OEX, 1945-1953, Stack area 230, Row 047, compartment 26, Shelf 6, Entry A1-1055, Box 15: 1951: Truman establishes psychological strategy board to coordinate psychological operations and report to NSC.

Documento 16: Nara II, RG 306, Declassified NN3-306-02-003, General Records of the United States Information Agency, Office of Administration; Historical Collection, Murray Lawson History Card Files Series; 1953-1975, State OIE/OII-OEX, 1945-1953 to State OIE/OII-OEX, 1945-1953, Stack area 230, Row 047, compartment 26, Shelf 6, Entry A1-1055, Box 15: 1951-53: Attempts to Unify Total U.S. Overseas Information Programs, Ludden, US Information, 214.

Documento 17: Nara II, RG 306, Declassified NN3-306-02-003, General Records of the United States Information Agency, Office of Administration; Historical Collection, Murray Lawson History Card Files Series; 1953-1975, State OIE/OII-OEX, 1945-1953 to State OIE/OII-OEX, 1945-1953, Stack area 230, Row 047, compartment 26, Shelf 6, Entry A1-1055, Box 15: 1951: Wilber - Authorization for responsibilities of POC/S in Psy Warfare.

Documento 18: Nara II, RG 306, Declassified NN3-306-02-003, General Records of the United States Information Agency, Office of Administration; Historical Collection, Murray Lawson History Card Files Series; 1953-1975, State OIE/OII-OEX, 1945-1953 to State OIE/OII-OEX, 1945-1953, 
Stack area 230, Row 047, compartment 26, Shelf 6, Entry A1-1055, Box 15: Times (London) writes major problem facing U.S. ability to succeed in Psy War attitude of Congress.

Documento 19: Nara II, RG 306, Declassified NN3-306-02-003, General Records of the United States Information Agency, Office of Administration; Historical Collection, Murray Lawson History Card Files Series; 1953-1975, State OIE/OII-OEX, 1945-1953 to State OIE/OII-OEX, 1945-1953, Stack area 230, Row 047, compartment 26, Shelf 6, Entry A1-1055, Box 15: 1952: Benton Calls for consideration of information factors in formulation of foreign policy (Ludden, US Information, 224 (Fulbright Hearings, Pt. 2, 799-808), 1952: Barrett calls for consideration of information factors in formulation of foreign policy (36 Fulbright Hearings, Pt. 2, p.638; for supporting statement by Mark May, see pp.258-9), Ludden, US Information, 224 (Fulbright Hearings, Pt. 2, 799-808).

Documento 20: Nara II, RG 306, Declassified NN3-306-02-003, General Records of the United States Information Agency, Office of Administration; Historical Collection, Murray Lawson History Card Files Series; 1953-1975, State OIE/OII-OEX, 1945-1953 to State OIE/OII-OEX, 1945-1953, Stack area 230, Row 047, compartment 26, Shelf 6, Entry A1-1055, Box 13: "U.S. - Brazil Cultural Agreement signed on October 17: First U.S. Bilateral Cultural Agreement 1950”; DOSB, 23 (30 Oct 50) 696-8.

Documento 21: Nara II, RG 306, Declassified NN3-306-02-003, General Records of the United States Information Agency, Office of Administration; Historical Collection, Murray Lawson History Card Files Series; 1953-1975, State OIE/OII-OEX, 1945-1953 to State OIE/OII-OEX, 1945-1953, Stack area 230, Row 047, compartment 26, Shelf 6, Entry A1-1055, Box 13: "1948: Physical Location of OIE in NYC”, HAC, State Approp 1949, p.273 (29 Jan 48); "1948: Hall - OIE moving from Argounaut Bldg in NYC to", HAC, 1 Def Approp. 48, p.1050 (10 Mar 48).

Documento 22: Nara II, RG 306, Declassified NN3-306-02-003, General Records of the United States Information Agency, Office of Administration; Historical Collection, Murray Lawson History Card Files Series; 1953-1975, State OIE/OII-OEX, 1945-1953 to State OIE/OII-OEX, 1945-1953, Stack area 230, Row 047, compartment 26, Shelf 6, Entry A1-1055, Box 13: "1953: Private Corporations sometimes formed to obtain IIA contracts for production and distribution of Information Materials (books E movies)", HAC, SUPP Approp '54, p.743 (24 June 53).

Documento 23: Nara II, RG 306, Declassified NND 36844, General Records of the United States Information Agency, Bureau of Programs; Historical 
Collection, Records relating to select USIA Programs; 1953-1999, Afghan Media project, 1985-1986 to Media Studies Journal, Summer, 1993, Stack area 230, Row 047, compartment 1, Shelf 1, Entry A1-1061, Box 15: "The International Information Administration Program", OIR/ERS - Evron M. Kirkpatrick, Rm. 600 - SA - 1, 49, CS/R, ps. 1-32.

Documento 24: Nara II, RG 306, Declassified NND 37109, General Records of the United States Information Agency (USIA); Office of the Director, Historical Collection; BIOGRAPHICAL FILES RELATING TO USIA DIRECTORS AND OTHER SENIORS OFFICIALS, 1953-2000, Robert W. Akers, Deputy USIA Director, 1965-1969 to George V. Allen, Publications, 1949-1969, 1951-1974 to USIS News Articles, 1975, Stack area 230, Row 047, compartment 12, Shelf 3, outcard 3, Entry A1-1069, Box 1, NN3-30602-003, June 23, 1949, Address by George V. Allen, Assistant Secretary of State for Public Affairs, "Where Do We Stand on Point Four?".

Documento 25: Nara II, RG 306, Declassified NND 022120, RECORDS OF THE UNITED STATES INFORMATION AGENCY (USIA); Legal Subject File, 1950-54; Eduardo Fernandez To Movie Tone's Inc.; Stack area 230, Row 46, compartment 2, Shelf 2, Entry 11, Box 19, "Villa Lobos and Jansen Symphony Orchestra at the Philharmonic Auditorium of Los Angeles on Sunday, November 19, 1944 - Museum of Modern Art of New York/Office of the Coordinator of Inter-American Affairs".

Documento 26: Nara II, RG 306, Declassified NND 37109, General Records of the United States Information Agency (USIA); Office of the Director, Historical Collection; REPORTS AND STUDIES, 1953-1998, Report on Travel Grant Program, 1942 to An Analysis of 885 Evaluation Reports on Foreign Grantees After Completion of Grant, 1953, Stack area 230, Row 047, compartment 28, Shelf 5, Entry A1-1070, Box 41, NN3-306-02-003, List of Exchanges of Specialists And Distinguished Leaders in the Western Hemisphere (July 1, 1940 - June 30, 1944)".

Documento 27: Nara II, RG 306, Declassified NND 36854, General Records of the United States Information Agency (USIA); Historical Collection, SUBJECT FILES; 1953-2000, Latin America, Foreign Grantees Name List, 1940-1975 to Latin America, Resource Guide, 1987, Stack area 230, Row 047, compartment 6, Shelf 3, Entry A1-1066, Box 60, "Program Of Interchange of Visiting Professors in the Western Hemisphere (Breakdown by Countries), July 1, 1940 - June 30, 1948".

Documento 28: Nara II, RG 306, Declassified NND 37109, General Records of the United States Information Agency (USIA); Office of the Director, Historical Collection; BIOGRAPHICAL FILES RELATING TO USIA 
DIRECTORS AND OTHER SENIORS OFFICIALS, 1953-2000, Elmer Davis Press Coverage, 1942-1964, to Bruce Geib, Press Coverages, 19891991, Stack area 230, Row 047, compartment 12, Shelf 3, outcard 3, Entry A1-1069, Box 7, NN3-306-02-003, "About General William "Wild Bill" Donovan", "Not One of Us Alone - A Mutual Security Program, by John Foster Dulles, Secretary of State".

Documento 29: Nara II, RG 306, Declassified NN3-306-02-003, General Records of the United States Information Agency, Office of Administration; Historical Collection, Murray Lawson History Card Files Series; 1953-1975, USIA News Clippings, 1953-1973 to USIA News Clippings, 1953-1973, Stack area 230, Row 047, compartment 26, Shelf 6, Entry A1-1055, Box 36, "Murrow's Philosophy of Propaganda", "1960: Free-Sorensen-Wilson did studies of USIA for Kennedy”, "1960: Sorensen Report Recommendations", "1961: A study of USIA for President-elected Kennedy: Murrow a member of the task force", "1963: I/R's Account of Changes in USIA/USIS During Murrow Administration".

Documento 30: Nara II, RG 306, Declassified NN3-306-02-003, General Records of the United States Information Agency, Office of Administration; Historical Collection, Murray Lawson History Card Files Series; 1953-1975, USIA News Clippings, 1953-1973 to USIA News Clippings, 1953-1973, Stack area 230, Row 047, compartment 26, Shelf 6, Entry A1-1055, Box 36, Los Angeles Times, 4 Mar 73, "The McCarthy Era: Hunting Reds in USIS Libraries", "1964-65: Rowan shared Kennedy-Murrow view of USIA as a useful tool of foreign policy - but not supported by White House", "1964-5: Rowan insists truth must be placed in perspective", "1964: Rowan - - just as important to keep goodwill of a friend as to win goodwill of a neutral/USIA Approp '65, p 1500 (July 1)'.

Documento 31: Nara II, RG 306, Declassified NN3-306-02-003, General Records of the United States Information Agency, Office of Administration; Historical Collection, Murray Lawson History Card Files Series; 1953-1975, USIA News Clippings, 1953-1973 to USIA News Clippings, 1953-1973, Stack area 230, Row 047, compartment 26, Shelf 6, Entry A1-1055, Box 36, "151 Statement by the President on the Responsibility for the United States Information Agency. July 30, 1953., Eisenhower, Papers of the President, 1:527”., "1964: Rowan - rates personal contact, radio $\mathcal{E} T V$ in order named as best media for influencing foreign opinion", "1965: Rowan describes machinery for giving USIA policy guidance/ S: USIA Approp. '66, p.237 (June 14)”.

Documento 32: Nara II, RG 306, Declassified NN3-306-02-003, General Records of the United States Information Agency, Office of Administration; 
Historical Collection, Murray Lawson History Card Files Series; 1953-1975, USIA News Clippings, 1953-1973 to USIA News Clippings, 1953-1973, Stack area 230, Row 047, compartment 26, Shelf 6, Entry A1-1055, Box 36, "History of the reorganization plan no. 8 of 1953", "1953: Reorganization plan no. 8 creates USIA", "1953: E.O. 10483 establishing the Operations Coordinating Board", "1964: Rowan - USIA's most important function is furthering U.S. Foreign Policy by influencing foreign attitudes". .

Documento 33: Nara II, RG 306, Declassified NN3-306-02-003, General Records of the United States Information Agency, Office of Administration; Historical Collection, Murray Lawson History Card Files Series; 1953-1975, State OIE/OII-OEX, 1945-1953 to State OIE/OII-OEX, 1945-1953, Stack area 230, Row 047, compartment 26, Shelf 6, Entry A1-1055, Box 17, "Release of McMahon Memorandum on U.S. International Information Program"., "Senator McCarthy's investigation of IIA personnel - Compton $\mathcal{E}$ Johnson victims" e "Purposes of McCarthy investigations - personal publicity E jobs for republicans", "1953: Eisenhower appointed Jackson Committee on January 26 to "Survey E Evaluate the Information Program", "1953: Smith-Mundt separation of "information" $\mathcal{E}$ "exchange" activities in Washington countered by union in the field with transfer of cultural officers to USIA complement", "Public Recommendations of Jackson Committee's report to President on U.S. Information Program".

Documento 34: Nara II, RG 306, Declassified NN3-306-02-003, General Records of the United States Information Agency, Office of Administration; Historical Collection, Murray Lawson History Card Files Series; 19531975, State OIE/OII-OEX, 1945-1953 to State OIE/OII-OEX, 19451953, Stack area 230, Row 047, compartment 26, Shelf 6, Entry A1-1055, Box 15, "1953: Senators Fulbright, Hickenlooper, Mundt ES Smith as well as exchange advisory commission were all opposed to transferring exchanges to USIA".

Documento 35: Nara II, RG 306, Declassified NN3-306-02-003, General Records of the United States Information Agency, Office of Administration; Historical Collection, Murray Lawson History Card Files Series; 1953-1975, State OIE/OII-OEX, 1945-1953 to State OIE/OII-OEX, 1945-1953, Stack area 230, Row 047, compartment 26, Shelf 6, Entry A1-1055, Box 21, "1952: Presidential candidate Eisenhower promises to make U.S. information programs more effective if elected", "Harris states Fulbright thinking of separation exchange program from info program, or exchange program from state", "Eisenhower approves the Rockefeller committee re-orientation, claims precisely what he wanted". 
Documento 36: Nara II, RG 306, Declassified NND 36854, General Records of the United States Information Agency (USIA); Historical Collection, SUBJECT FILES; 1953-2000, Latin America, 1939-2000 to Latin America, 1979-1990, Stack area 230, Row 047, compartment 6, Shelf 3, Entry A11066, Box 214, "Around the Good Neighbor Network, 1951", "Bulletin of the Pan American Union, 1947”.

Documento 37: Nara II, RG 306, Declassified NND 36854, General Records of the United States Information Agency (USIA); Historical Collection, SUBJECT FILES; 1953-2000, Organization, News Articles, 1955-1974 to Agency Mission, 1947-1969, Stack area 230, Row 047, compartment 6, Shelf 3, Entry A1-1066, Box 2, "America's Overseas Information Program: How it Began... What It Means Today".

Documento 38: Nara II, RG 306, Declassified NN3-306-02-003, General Records of the United States Information Agency, Office of Administration; Historical Collection, Murray Lawson History Card Files Series; 1953-1975, State OIE/OII-OEX, 1945-1953 to State OIE/OII-OEX, 1945-1953, Stack area 230, Row 047, compartment 26, Shelf 6, Entry A1-1055, Box 20, "1952: IIA reports "Country Plan" E "Country Prospectus" the two basic documents underlying the new country concept of planning", "1953: Eisenhower's state of union message on U.S. foreign information activities and implementation of this objective".

Documento 39: Nara II, RG 306, Declassified NND 37109, General Records of the United States Information Agency (USIA); Office of the Director, Historical Collection; AGENCY HISTORY PROGRAM SUBJECT FILES, 1967-1975, Mission Statements, 1945-1967 to Missions and Chief Officers, 1962, Stack area 230, Row 047, compartment 13, Shelf 1, Entry A1-1072, Box 5, NN3-306-02-003, "Rockefeller Report/Executive Office of the President, President's Advisory Committee on Government organization, April 7, 1953".

Documento 40: Nara II, RG 306, Declassified NN3-306-02-003, General Records of the United States Information Agency, Office of Administration; Historical Collection, Murray Lawson History Card Files Series; 19-1975, State OIE/OII-OEX, 1945-1953 to State OIE/OII-OEX, 1945-1953, Stack area 230, Row 047, compartment 26, Shelf 6, Entry A1-1055, Box 13, "The United States Advisory Commission on Information".

Documento 41: Rockefeller Archives Center, Tarrytown, Collection: Nelson A. Rockefeller papers, Washington, DC, Series O, Subseries O.5: Special Committee on Government Organization (SCOGO), Reorganization Advisory Committee (RAC), President's Advisory Committee on Government 
Organization (PACGO), Series O.5A: Special Committee on Government Organization (SCOGO), General Correspondence, Memos and Clippings, 1952-1953, Box 45, Folder 388, "Brother Milton To Make Good-Will Pan Am Tour".

Documento 42: Rockefeller Archives Center, Tarrytown, Collection: Nelson A. Rockefeller papers, Washington, DC, Series O, Subseries O.5: Special Committee on Government Organization (SCOGO), Reorganization Advisory, Committee (RAC), President's Advisory Committee on Government Organization (PACGO), Series O.5A: Special Committee on Government Organization (SCOGO), State Department, 1952-1953, Box 48, Folder 410, "Draft of Letter to John Foster Dulles, 12/22/52".

Documento 43: Nara II, RG 306, Declassified NN3-306-02-003, General Records of the United States Information Agency, Office of Administration; Historical Collection, Murray Lawson History Card Files Series; 1953-1975, Radio Free Europe/Radio Liberty, 1953-1975 to Radio Free Europe/Radio Liberty, 1953-1975, Stack area 230, Row 047, compartment 26, Shelf 6, Entry A1-1055, Box 27, "1953: Milton Eisenhower claims Institutes, Bi-National Centers, E Exchange Program, most effective part of USIA, August 5, 1953”, "Milton S. Eisenhower, State College, Pennsylvania, to Mr. Streitbert, August 8, 1953”.

Documento 44: Rockefeller Archives Center, Tarrytown, Collection: Nelson A. Rockefeller papers, Projects, Series L, Subseries.: Theodore Streitbert, USIA; Radio Free Europe, Box 237, Folder 2381.

Documento 45: Nara II, RG 306, General Records of the United States Information Agency (USIA); Office of the Director, Historical Collection; BIOGRAPHICAL FILES RELATING TO USIA DIRECTORS AND OTHER SENIORS OFFICIALS, 1953-2000, Robert E. Sherwood, 1945-1956, to Theodore Streitbert, Press Coverage, 1953-1956, Stack area 230, Row 047, compartment 12, Shelf 7, Entry A1-1069, Box 29, NN3-306-02-003. Artigo "You Can't Shoot An Idea", "Address by Theodore C. Streitbert, Director of the U.S. Information Agency, at the Women's National Press Club Luncheon, Hotel Lafayette, Washington, D.C., Thursday, October 28, 1954, 12:30 p.m., The War for Men's Minds".

Documento 46: Nara II, RG 306, Declassified NN3-306-02-003, General Records of the United States Information Agency, Office of Administration; Historical Collection, Murray Lawson History Card Files Series; 1953-1975, State OIE/OII-OEX, 1945-1953 to State OIE/OII-OEX, 1945-1953, Stack area 230, Row 047, compartment 26, Shelf 6, Entry A1-1055, Box 24, "1953: Dulles - Favors a Cultural Relations Program For Latin America". 
Documento 47: Nara II, RG 306, Declassified NN3-306-02-003, General Records of the United States Information Agency, Office of Administration; Historical Collection, Murray Lawson History Card Files Series; 1953-1975, Pre 1953 Staffing Patterns, 1945-1953 to Pre 1953 Staffing Patterns, 19451953, Stack area 230, Row 047, compartment 26, Shelf 6, Entry A1-1055, Box 28, "1956 (FEB): USIA Office Directory".

Documento 48: Nara II, RG 306, Declassified NN3-306-02-003, General Records of the United States Information Agency, Office of Administration; Historical Collection, Murray Lawson History Card Files Series; 1953-1975, USIA News Clippings, 1953-1973 to USIA News Clippings, 1953-1973, Stack area 230, Row 047, compartment 26, Shelf 6, Entry A1-1055, Box 37, "1953: Total USIA Employment on December 31 By Element”, "1953-62: USIA Authorized Personnel Strength”, "1961: Murrow not Kennedy's first choice as agency director", "1956: Rockefeller writes Dulles ISA System needed to reduce confusion which exists in overseas personnel field"., "Overseas Personnel", "1963: Murrow came down with cancer in September: resigned in until January 20/64".

Documento 49: Nara II, RG 306, Declassified NND 36854, General Records of the United States Information Agency (USIA); Historical Collection, SUBJECT FILES; 1953-2000, Organization, News Articles, 1955-1974 to Agency Mission, 1947-1969, Stack area 230, Row 047, compartment 6, Shelf 3, Entry A1-1066, Box 2, "Excerpt from Mr. Eisenhower's Foreign Policy Speech, San Francisco, October 8, 1952”, "The Federal Diary, by Dwight D. Eisenhower, October 30, 1952", "Purpose of the U.S.I.A”., "Operating Responsibilities and relationships for the United States Information Agency", "Organization of the U.S. Overseas Information program, 1945-1958", "1963: Murrow came down with cancer in September: resigned in December but note accepted until January 20/64".

Documento 50: Nara II, RG 306, Declassified NN3-306-02-003, General Records of the United States Information Agency, Office of Administration; Historical Collection, Murray Lawson History Card Files Series; 1953-1975, Post 1953 Staffing Patterns, 1953-1973 to Post 1953 Staffing Patterns, 19531973, Stack area 230, Row 047, compartment 26, Shelf 6, Entry A1-1055, Box 30, "1954-: Sports made an integral part of President's Special International Program", "1954-7: Description of USIA Art Exhibits", "The USIA E Art Exhibits”, "1954-: President's Emergency fund for artistic performances established because of soviet cultural offensive: made permanent in 1956 $\mathcal{E}$ transferred to state: advisory committee on the arts established", "1955-: Geographical breakdown of State's Cultural-Sports Program in FY 56-58”, “1955: United States Has Secret Sonic Weapon-Jazz", "1956: "Teahouse 
of August Moon" flops in Rio de Janeiro", "1956: Jazz Offers U.S. Greatest opportunity to Win Friends", "In Latin America Joseph Fuchs Discusses His Recent Tour", "Dizzy rated Higher U.S. pay than Ike", "Sinfonietta Heading For Latin America", "Acting Ambassadors".

Documento 51: Nara II, RG 306, Declassified NN3-306-02-003, General Records of the United States Information Agency, Office of Administration; Historical Collection, Murray Lawson History Card Files Series; 1953-1975, USIA News Clippings, 1953-1973 to USIA News Clippings, 1953-1973, Stack area 230, Row 047, compartment 26, Shelf 6, Entry A1-1055, Box 33, "USIA Film Audience Increased by 200 Million", "Streitbert - USIA Concentrating on Anti-Communist Films \& Making Them Overseas", "1954: In FY55 Most Documentaries To Be Produced O/S And To Stress Either Anti-Communism and Virtues of American Democracy", "1954: Streitbert - USIA Seeking Hollywood's Help in Making Documentaries", "1954: Streitbert - Seeking Specialized Not Mass Audiences for USIA Films", "Completed productions contracted in fiscal year 1953", "1954: Streitbert Interested in 3 types of Films (Anti-communist, Pro-U.S., Topical)", "1955: USIA claims Hollywood Films Often Misrepresent U.S.), e "1955: Brazil Prohibits Importation of Newsreels hence produced locally", "1959: USIA's Overseas Film Program", "1963: USIA Films Admirable Lot", de Richard L. Coe, Washington Post"; "1962: USIA Film Depicts Positive Negro Gain", "1961: Murrow tried "to influence" Hollywood films to improve U.S. image abroad", "1961: Murrow urges Hollywood to portray U.S. more accurately in its films"., "Fine Kennedy Film, - Only for Abroad/ NY Times/Judith Crist", "1963-4: Stevens - Documentary on "The President" completed in four weeks/ H: USIA Approp '65, p.397 (4 mar 64)”.

Documento 52: Nara II, RG 306, Declassified NND 36854, General Records of the United States Information Agency (USIA); Historical Collection, SUBJECT FILES; 1953-2000, People to People Program, 1951-1973 to People to People Program, 1951-1973, Stack area 230, Row 047, compartment 6, Shelf 3, Entry A1-1066, Box 199, "What you should know about the People-to-People Program: How it Operates... what you can do.."., "Stamp Collecting and People-to-People", "Your Community in world affairs", "A program of international friendship", "The letter writing Committee of the President's People-to-People Program of the United States", "People-to-People Hobbies Committee", "People in the World Disabled", "Make a friend this trip", "How to organize a People-to-People Council in your Community", "Town Affiliation - your Community in the World" e "Hobby Found Peacemaker in International Strife". 
Documento 53: Nara II, RG 306, Declassified NND 36854, General Records of the United States Information Agency (USIA); Historical Collection, SUBJECT FILES; 1953-2000, People to People Program, 1954-2000 to People to People Program, 1954-2000, Stack area 230, Row 047, compartment 6, Shelf 3, Entry A1-1066, Box 200, "Cartoonists defend American tourists", "Sister City Program Expanding. May, 1963”.

Documento 54: Rockefeller Archives Center, Tarrytown, Collection: Nelson A. Rockefeller papers, Washington, DC, Series O, Subseries O.7: Special Assistant to the President for Foreign Affairs (SAP), Quantico II - Final Report, "Psychological Aspects of Future United States Strategy", Box 68, Folder 548. Disponível em: <http://dimes.rockarch.org/xtf/view?docId=ead/ FA350/FA350.xml;query $=;$ brand $=$ default; chunk. id $=$ ref786; doc. view $=$ contentsref $868>$. Acesso em: 20 nov. 2014.

Documento 55: Rockefeller Archives Center, Tarrytown, Collection: Nelson A. Rockefeller papers, Washington, DC, Series O, Subseries O.9: Special Assistant to the President Declassified Materials, Office of Non-Military Warfare (ONMW) - Psychological Warfare - Drafts, 1955, Box 1, Folder 13. Disponível em: <http://dimes.rockarch.org/xtf/view?docId=ead/ FA350/FA350.xml;query $=$; brand $=$ default; chunk. id $=$ ref2289; doc. view $=$ contentsref2315>. Acesso em: 20 nov. 2014 .

Documento 56: Nara II, RG 306, Declassified NND 36854, General Records of the United States Information Agency (USIA); Historical Collection, SUBJECT FILES; 1953-2000, People to People Program, 1951-1973 to People to People Program, 1951-1973, Stack area 230, Row 047, compartment 6, Shelf 3, Entry A1-1066, Box 199, "Portraying American culture to the world: U.S. Information Agency", "The free world speaks, 1951" e "What should I know when I travel abroad".

Documento 57: Nara II, RG 306, Declassified NND 37109, General Records of the United States Information Agency (USIA); Office of the Director, Historical Collection; BIOGRAPHICAL FILES RELATING TO USIA DIRECTORS AND OTHER SENIORS OFFICIALS, 1953-2000, Edward R. Murrow, Photographs, Awards E Presentations, 1961-1964, to Edward R. Murrow, Photographs, Journalists, 1963-1998, Stack area 230, Row 047, compartment 12, Shelf 3, outcard 3, Entry A1-1069, Box 19, NN3-306-02-003.

Documento 58: Nara II, RG 306, Declassified NND 37109, General Records of the United States Information Agency (USIA); Office of the Director, Historical Collection; BIOGRAPHICAL FILES RELATING TO USIA DIRECTORS AND OTHER SENIORS OFFICIALS, 1953-2000, Edward 
R. Murrow, Press Coverage, Jan. 1961 - March 1961, to Edward R. Murrow, Press Coverage, Jan. 1961 - March 1961, Stack area 230, Row 047, compartment 12, Shelf 3, outcard 3, Entry A1-1069, Box 15, NN3-306-02-003, Reading Times, 17/02/1961, "Now a Word From My Sponsor", "The White House, Text of letters exchanged by the President and the Honorable Edward R. Murrow, January 20, 1964".

Documento 59: Nara II, RG 306, Declassified NND 37109, General Records of the United States Information Agency (USIA); Office of the Director, Historical Collection; BIOGRAPHICAL FILES RELATING TO USIA DIRECTORS AND OTHER SENIORS OFFICIALS, 1953-2000, Donald M. Wilson, Speeches, 1961-1969, to Directors, Nominations, 1977-1981, Stack area 230, Row 047, compartment 12, Shelf 3, Entry A1-1069, Box 37, NN3306-02-003, “"Wilson Steps Out Aug. 1 As USIA Deputy Chief”.

Documento 60: $R G$ 306, General Records of the United States Information Agency (USIA); Office of the Director, Historical Collection; BIOGRAPHICAL FILES RELATING TO USIA DIRECTORS AND OTHER SENIORS OFFICIALS, 1953-2000, Eward R. Murrow, Press Coverage, Nov. 1961 - Dec. 1965, to Edward R. Murrow, Press Coverage, Nov. 1961 - Dec. 1965, Stack area 230, Row 047, compartment 12, Shelf 3, outcard 3, Entry A1-1069, Box 17, NN3-306-02-003, "The Edward R. Murrow center of Public Diplomacy/The Agency Library, archives collection", "Murrow to Rowan, U.S. to the World (Springfield, Mass. Union, Jan 23, 1964)", "Ed Murrow's Contribution (Roanoke, Virginia Times, Jan 26, 1964)".

Documento 61: Nara II, RG 306, Declassified NND 931587, RG 306, RECORDS OF THE UNITED STATES INFORMANTION AGENCY (USIA); Office of Research and Intelligence; Headquarters Subject Files, 1955-1970; Stack area 230, Row 47, compartment 19, Shelf 5, Entry A11048, Box 11, "IRS - U.S. News Media Representatives serving abroad".

Documento 62: Nara II, RG 306, Declassified NND 37109, General Records of the United States Information Agency (USIA); Office of the Director, Historical Collection; BIOGRAPHICAL FILES RELATING TO USIA DIRECTORS AND OTHER SENIORS OFFICIALS, 1953-2000, Carl T. Rowan, 1957-1998, to Howland H. Sergeant, Asst. Secretary of State for Public Affairs, 1947-1953, Stack area 230, Row 047, compartment 12, Shelf 6, Entry A1-1069, Box 26, NN3-306-02-003, "The White House, Exchange of letters between President Johnson and Carl T. Rowan, July 1965", "Rowan's speech to L.A. Ambassadors, mar 11, 1964", "On the Propaganda War: Latin America... - Printing Week Convention, Minneapolis, Minn., February 21, 1964". 
Documento 63: Nara II, RG 306, Declassified NND 988085, RECORDS OF THE UNITED STATES INFORMATION AGENCY (USIA); Office of Research; Special Reports (S), 1953-1997, S-16-55 THRU S-2-56; Stack area 230, Row 48, compartment 27, Shelf 5, Entry P-160, Box 9 ARC 5664216.

Documento 64: Nara II, RG 306, Declassified NND 968139, RECORDS OF THE UNITED STATES INFORMATION AGENCY (USIA); Master Budget Files; 1953-1967, Stack area 230, Row 46, compartment 16, Shelf 4, Entry A1-56, Box 4, "1954-55 IIA Prospectus for Brazil/April 1953".

Documento 65: Nara II, RG 306, Declassified NND 36854, General Records of the United States Information Agency (USIA); Historical Collection, SUBJECT FILES; 1953-2000, Damage to USIA Property, 1953-1985 to Architecture, 1996-1999, Stack area 230, Row 047, compartment 6, Shelf 3, Entry A1-1066, Box 208, "Attacks against USIS installations since August 1, 1953 to date which have occurred for a wide variety of reasons, some political/ U.S. Information Agency".

Documento 66: Declassified NND 988085, Nara II, RG 306, stack area 230, row 046, compartment 024, shelf 5, Entry 1010, Box 2, Records of the US Information Agency, Office of Research, Public Opinion Barometer Reports, 1955-1962, LA-1 to 2nd Series LA-5, Box 2, ARC ID 1101836, A1, Entry 1010, LA 15, "A note on the impact of Vice-President Nixon's trip on public opinion in three latin-american cities, Report 15, June, 1958", "LA-1, Some basic political and economic attitudes in six Latin American cities, Report 1, June 29, 1955", "LA-8, (Mexican and Brazilian attitudes toward Communism, Report 8, July 2, 1959)", "LA-11 a LA-16, sendo: LA-11 (Latin American attitudes toward US economic policies, Report 1, June 28, 1957)".

Documento 67: Collection: Nelson A. Rockefeller papers, Washington, DC, Series O, Subseries O.7: Special Assistant to the President for Foreign Affairs (SAP), Latin America - Countries (Brazil), Box 88, Folder 664

Disponível em: <http://dimes.rockarch.org/xtf/view?docId=ead/ FA350/FA350.xml;query $=$; brand $=$ default; chunk. id $=$ ref786; doc. view $=$ contentsref1056>. Acesso em: 11 dez. 13 .

Documento 68: NARA II, Still Pictures, RG 306, Box 25, photo 56-2304, "Volta Redonda, Brazil. Vice President Nixon and President Juscelino Kubitschek of Brazil look over the huge steel mill. Source: Assoc Press. 2/3/56 copy neg".

Documento 69: Nara II, RG 306, Declassified NND 988085, Records of the United States Information Agency, Office of Research and Analysis; Research Reports; 1956-1959, 1959: P-36 THRU 1959: P-57, Stack area 230, Row 046, compartment 36, Shelf 6, Entry A1-1033, Box 7, ARC 1074148, 
"UNTAPPED RESOURCE: RESEARCH RECORDS OF THE UNITED STATES INFORMATION AGENCY, by Kenneth W. Heger $\mathcal{E}$ David A. Langbart, The Shafr Newsletter".

Documento 70: Nara II, RG 306, Declassified NND 988085, Records of the United States Information Agency, Office of Research and Analysis; Research Reports; 1956-1959, 1959: P-36 THRU 1959: P-57, Stack area 230, Row 046, compartment 36, Shelf 6, Entry A1-1033, Box 7, ARC 1074148, "USIA Historical Collection".

Documento 71: Nara II, RG 306, Declassified NND 988085, Records of the United States Information Agency, Office of Research, Multi Country (Area) Project Files, 1952-1963, Latin America, 1953 to Latin America, 1957, Stack area 230, Row 046, compartment 035, Shelf 02, Entry A1-1023, Box 4, ARC ID 1074070, "The reactions of Latin-Americans Listeners to two programs broadcast over Station WRUL, New York city, nov. 1953”, "ZP 5303, Radio Listening, multi-Latin American, 6 Latin American cities radio listening + political attitudes, mar. 1955", "ZP 5302, Radio Listening, Multi Latin America, give-away offer on WRUL (responses), nov.-dec. 1953".

Documento 72: Nara II, RG 306, Declassified NND 988085, Records of the United States Information Agency, Office of Research Records and Intelligence, Bulletins, memorandums and Summaries; 1954-1956; 1956: IM-21 thru 1955: IS-27, Stack area 230, Row 046, compartment 035, Shelf 01, Entry A1-1022, Box 4, ARC 1073965, "IS- 6-54, Report on "Communism in Brazil", 25-6-54", "IS-3-55, Communist attempts to obstruct development of petroleum industry in Brazil, January 28, 1955", "IM-23- 56, Latin American reactions to the Panama Meeting of Presidents of the American Republics, August 15, 1956".

Documento 73: Nara II, RG 306, Declassified NND 931587, RECORDS OF THE UNITED STATES INFORMATION AGENCY (USIA); Office of research and Intelligence; Headquarters Subject Files, 1955-1970; Stack area 230, Row 47, compartment 19, Shelf 5, Entry A1-1048, Box 7, "Department of Defense Special Operations Research Fields", "IRI Memorandum requesting subject report of December 15, 1955", "Project at Western Reserve Document Center".

Documento 74: Nara II, RG 306, Declassified NND 931613, RECORDS OF THE UNITED STATES INFORMATION AGENCY (USIA); INSPECTION STAFF; Inspection reports and Related Records, 1954-1962; Afghanistan THRU British East Africa, Stack area 230, Row 17, compartment 18, Shelf 7, Entry A1-1045, Box 1, H. M. Done 1989, "INSPECTION REPORT, USIS Brazil, 1960", "Contract No. Ia-6fa-17/Diários 
Associados, 1954", "Inspection Report of USIS Brazil, August 15-September 28, 1955”, "Inspection Report, USIS-Brazil, October 21, 1960", "Record of Meeting in Mr. Vebber's Office - September 9, 1955”.

Documento 75: Nara II, RG 306, Declassified NN D 988085, stack area 230, row 046, compartment 024-25, shelf 7-1, Country Project Files, 1951-1964, Brazil, 1955 to Brazil, 1958, Box 9, ARC ID 1065787, Entry1015, "InRa Survey of Brazilian Opinions on Foreign Investments Reported in New York Times, April 30”., "BR 5602 set.1956 BRA media habits", "BR 5603 fev. 1957 (LA6) - (A study of Brazilian Public Opinion on selected national and international issues)", "BR5802, abr. 1958 - Television Viewing”, “BR 5801, nov 1958 - Nationalism Study", "BR 5401/ USIA Exhibit "Atoms for the benefit of Mankind” held at the Exposição do IV Centenário da Cidade de São Paulo, from August 1954 to January 1955".

Documento 76: Nara II, RG 306, Declassified NND 988085, Records of the United States Information Agency, Office of Research and Reference; Requestor Only Reports; 1956-1962, RO 1959 THRU RO/LA 1960, Stack area 230, Row 046, compartment 36, Shelf 05-, Entry A1-1032, Box 1, ARC 1074138, "RO/LA-37-58, Analysis of Letters of reaction to Combate, 12/30/58”, "RO/LA 1960, 101-116 Complete, 1960”, “RO/LA 1960, 81100 Complete, 1960 ”.

Documento 77: Nara II, RG 306, Declassified NND 988085, Records of the United States Information Agency, Office of Research and Analysis; Research Notes; 1958-1962, 1959: RN-91 THRU 1960: RN-20, Stack area 230, Row 046, compartment 36, Shelf 02 -, Entry A1-1029, Box 3, ARC 1074117, "RN-86-59, Fact Book on Latin America, June 29, 1959".

Documento 78: Nara II, RG 306, Declassified, US Information Agency; Office of Research and Reference/ Agency Library; International Survey Research Reports; 1953-1964, IRI BR 67: A Study of Wrul's Transmission to Brazil: O Vespertino Do Ar"-April, 1959 THRU IEV CHL 1: Attitudes toward the U.S. and Exposure to the Mass Media and the USIS (United States Information Service) Program in Chile - July 1953, Stack area 230, Row 47, compartment 22, Shelf 4, Entry P-78, Box 14, ARC 721251, "A Study of Wrul's Transmission to Brazil "O Vespertino Do Ar", 1959", "Brazilian Public opinion Surveys, Series 7, Report 4, December 22, 1959", "Sample copies of: Desfile do Mundo para seu Lar", "Singra", "Gazeta Comercial” e "A Gazeta"," "Utilization and Opinions of USIS Brazil - Media Press Services", "Some International Implications of THE POLITICAL PSYCHOLOGY OF BRAZILIANS, by Lloyd A. Free, July, 1961", "RIO's FAVELAS, the rural slum within the city, august 1961". 
Documento 79: Nara II, RG 306, Declassified NND 988085, Stack Area 230, Row 046, compartment 024-25, shelf 7-1Records of the U.S. Information Agency, Office of Research, Country Project Files, 1951-1964, Brazil, 1961 to Brazil, 1963, Box 11 ARC ID 1065787, A1, Entry 1015, "62-007, Brazil in Crisis, public opinion reaction in Rio and SP about the US - crisis Janio, 1961", "BR 6102, Brazil in Crisis attitudes, Cuban-USA crisis opinion survey, sept. 1961".

Documento 80: Nara II, RG 306, Declassified NND 988085, Records of the United States Information Agency, Office of Research and Reference; Requestor Only Reports; 1956-1962, RO 1961 THRU RO/PI, Stack area 230, Row 046, compartment 36, Shelf 05-, Entry A1-1032, Box 2, ARC 1074138, "RO/LA 1961, 82-110 (Incomplete), 1961", "RO/LA, 101-126, 1962".

Documento 81: Declassified NN D 988085, Nara II, RG 306, stack area 230, row 046, compartment 024-25, shelf 7-1, Records of the U.S. Information Agency, Office of Research, Country Project Files, 1951-64, Brazil, 1963 to Brazil, 1963, Box 15, ARC ID 1065787, A1, Entry 1015, "BR 6306, Attitudes on Race+Astronauts, May 1963".

Documento 82: Declassified NN D 988085, Nara II, RG 306, stack area 230, row 046, compartment 024-25, shelf 7-1, Records of the U.S. Information Agency, Office of Research, Country Project Files, 1951-64, Brazil, 1963 to Brazil, 1963, Box 14, ARC ID 1065787, A1, Entry 1015, BR 6302, "Economic attitudes in rural NE Brazil \& attitudes on Alliance for Progress, March 1963".

Documento 83: Nara II, RG 306, Declassified NND 927503RG 306, Records of the United States Information Agency, Office of Research Records of Research Projects, Latin America, 1964-73, Stack area 230, Row 046, compartment 030, Shelf 02, Entry A1-1018, BR 6402, Brazil, Political Semantics thru BR 6501, Brazil, Alliance for Progress, Box 3, HM FY1991, "BR 6403, Brazil Students Attitudes (Bryant Wedge Study), Oct. 1964-65", "Bryant Wedge to John Evans, 5 February 1965”, "BR 6403, Brazil Effect of Media on Politics, 1964".

Documento 84: NARA II, Still Pictures, RG 306, Box 81, photo 64-1934, "Brazil: Brazilian National Students Union Headquarters, showing posters printed by the organization announcing fair to commemorate 42nd anniversary of Brazilian Communist Party. On Wall, photograph of Cuban Leader Ernesto "Che" Guevara. Source: USIS Rio C.N. Brazil, Posters-Foreign-Brazil Propaganda-Communist-Communism-Brazil", 24/4/1964, "photo 64-1546, Brazil: Weapons confiscated from Communist Organizations, and individuals who planned Communist Revolution"., "photo 64-1555, Rio de Janeiro, Brazil: Address labels from Propaganda material direct from Moscow and Peking 
to a communist-dominates student organization, the União Fluminense dos Estudantes. The material was seized by authorities after the April Revolution. Source: USIS Brazil, Copy Neg., Brazil, Rio de Janeiro”, "photo 64-1522, 02/abril/1964, Rio de Janeiro: Cheering, Flag-waving crowd of Brazilians in front of Guanabara palace celebrate successful revolution: 4/2/64, Source USIS/Brazil, Copy Neg”..

Documento 85: Nara II, RG 306, Declassified NND 927503RG 306, Records of the United States Information Agency, Office of Research Records of Research Projects, Latin America, 1964-73, Stack area 230, Row 046, compartment 030, Shelf 02, Entry A1-1018, BR 6502, Brazil, General Attitudes thru BR 6701, Brazil, Radio Listening, Box 4, HM FY1991, "BR 6504, Brazil Paths to Leadership, june 1965", "Brazil Radio Listening, Mar 1969".

Documento 86: Nara II, RG 306, Declassified NND 927503RG 306, Records of the United States Information Agency, office of Research Records of Research Projects, Latin America, 1964-73, Stack area 230, Row 046, compartment 030, Shelf 02, Entry A1-1018, AR6602, Argentina, media habits thru BR 6402, Brazil, Political Semantics, Box 2, HM FY1991, "AR GG3, Folder "Alboreal Book Collection, 1966", "BR 6401, Brazil, Reaction to "The President" Film, Apr. 1964".

Documento 87: Nara II, RG 306, Declassified NND 998107, RECORDS OF THE UNITED STATES INFORMATION AGENCY (USIA); Subject Files; 1953-1967, Stack area 230, Row 46, compartment 16, Shelf 4, Entry A1-56, Box 26, "Brazil, 1957”.

Documento 88: Nara II, RG 306, Declassified NN3-306-02-003, General Records of the United States Information Agency, Office of Administration; Historical Collection, Murray Lawson History Card Files Series; 1953-1975, USIA News Clippings, 1953-1973 to USIA News Clippings, 1953-1973, Stack area 230, Row 047, compartment 26, Shelf 6, Entry A1-1055, Box 31, "1954- : DISTRIBUTION OF REPRESENTATION FUNDS FOR FY55 BY COUNTRY”.

Documento 89: Nara II, RG 306, Declassified NN3-306-02-003, General Records of the United States Information Agency, Office of Administration; Historical Collection, Murray Lawson History Card Files Series; 1953-1975, USIA News Clippings, 1953-1973 to USIA News Clippings, 1953-1973, Stack area 230, Row 047, compartment 26, Shelf 6, Entry A1-1055, Box 32, "1957: ORAM - USIA SUPPORTING 70 BNCs IN LATIN AMERICA: DESCRIPTION”.

Documento 90: Nara II, RG 306, Declassified NND 37109, General Records of the United States Information Agency (USIA); Office of the Director, 
Historical Collection; BIOGRAPHICAL FILES RELATING TO USIA DIRECTORS AND OTHER SENIORS OFFICIALS, 1953-2000, George V. Allen, Speeches, 1957-1960, to George V. Allen, Speeches, Press Coverages, 1958-1959, Stack area 230, Row 047, compartment 12, Shelf 3, outcard 3, Entry A1-1069, Box 4, NN3-306-02-003, "Mutual understanding through binational activities, George V. Allen, Seventh national Conference, Denver, Colorado, September 29 - October 2, 1959".

Documento 91: Nara II, RG 306, Declassified NND 927503, Records of the United States Information Agency, office of Research Records of Research Projects, Latin America, 1964-73, Stack area 230, Row 016, compartment 030, Shelf 02, Entry A1-1018, AR7101, BR 7302, Brazil Binational Centers, Box No. 24, "BR 7302, Binational Centers, Brazil, evaluation of BNC program in Brazil-survey of BNC patrons, sept. 1973, INESE, São Paulo".

Documento 92: Nara II, RG 306, Declassified NND 988085, Records of the United States Information Agency, Office of Research and Evaluation; Estimates and Evaluation; 1966-1978, 1974: E-6 THRU 1976: E-18, Stack area 230, Row 046, compartment 36, Shelf 01-, Entry A1-1028, Box 4, ARC 1074103, "E-2-76, Study of Binational Centers in Brazil, 1976".

Documento 93: Collection: Nelson A. Rockefeller papers, Washington, DC, Series O, Subseries O.7: Special Assistant to the President for Foreign Affairs (SAP), United States Information Agency - General, Box 83, Folder 633: "Barometer and Rockefeller, 1955". Disponível em: <http://dimes.rockarch.org/ $\mathrm{xtf} /$ view?docId=ead/FA350/FA350.xml;query=; brand=default; chunk. id=ref786; doc.view =contentsref999>. Acesso em: 21 dez. 2013.

Documento 94: Nara II, RG 306, Declassified NND 74626, RECORDS OF THE UNITED STATES INFORMATION AGENCY (USIA); Information Center Service/Information Media Guaranty/Liquidation Staff; Administrative Files, 1949-1967, Proposed IMG - Brazil THRU Proposed IMG - Egypt (1956-1965); Stack area 350, Row 73, compartment 10, Shelf 6, Entry P-56, Box 9 ARC 4700155, "Country Plan, 1953", "Treatment of Infiltration and Subversion in Brazil, April 14, 1964".

Documento 95: Nara II, RG 306, Declassified NND 988085, Records of the United States Information Agency, Office of Research and Intelligence, Intelligence Bulletins, memorandums and Summaries; 1954-1956; 1954: IM-31 thru 1955: IM-75, Stack area 230, Row 046, compartment 035, Shelf 01, Entry A1-1022, Box 2, ARC 1073965, "IM-24-55, MATERIALS REQUESTED FOR BUDGET HEARINGS, Selected Communist Publications in Latin America, March" 2, 1955", "IM-46-55, Recents Developments in Latin American Television, March 31, 1955". 
Documento 96: Nara II, RG 306, Declassified NND 988085, Records of the United States Information Agency, Office of Research and Intelligence, Intelligence Bulletins, memorandums and Summaries; 1954-1956; 1955: IB-1 thru 1954: IM-30, Stack area 230, Row 046, compartment 035, Shelf 01, Entry A1-1022, Box 1, ARC 1073965, "IB-4-56, Foreign Reaction to Presidente Eisenhower's uranium offer of February 22, 1956, March 15, 1956".

Documento 97: Nara II, RG 306, Declassified NND 988085, Records of the United States Information Agency, Office of Research and Intelligence, Intelligence Bulletins, memorandums and Summaries; 1954-1956; 1955: IM-76 thru 1956: IM-20, Stack area 230, Row 046, compartment 035, Shelf 01, Entry A1-1022, Box 3, ARC 1073965, "IM-17-56, Brazilian Opinion of US Policies, January 1955- June 1956".

Documento 98: Nara II, RG 306, Declassified NN3-306-02-003, General Records of the United States Information Agency (USIA); Historical Collection, PROPAGANDA COUNTRY FILES; 1953-1991, Argentina to Uruguay, Stack area 230, Row 47, compartment 1, Shelf 2, Entry A1-1068, Box 41, "A Morte vem de Moscou (O Globo), 1956", "Radio Press, divulgação interna, 1956”.

Documento 99: Nara II, RG 306, RECORDS OF THE UNITED STATES INFORMANTION AGENCY (USIA); PROBLEMS OF COMMUNISM, 1952-73, Problems of Communism, 1972-1973 thru Problemas Internacionales, 1954-1973, Stack area 230, Row 46, compartment 1, Shelf 4, Entry 3, Box 3 NN3-306-93-003, "Problemas do Comunismo, 1957".

Documento 100: Nara II, RG 306, Declassified NND 988085, Records of the United States Information Agency, Office of Research and Analysis; Research Notes; 1958-1962, 1958: RN-1 THRU 1958: RN-58, Stack area 230, Row 046, compartment 36, Shelf 02-, Entry A1-1029, Box 1, ARC 1074117, "RN-6-58, Selected List of Important Non-Communist Newspapers and Magazines in Latin America, January 27, 1958”.

Documento 101: Nara II, RG 306, Declassified NND 988085, RG 306, Records of the United States Information Agency, Office of Research and Analysis; Research Notes; 1958-1962, 1960: RN-21 THRU 1962: RN-13, Stack area 230, Row 046, compartment 36, Shelf 02 -, Entry A1-1029, Box 4, ARC 1074117, "RN-10-61, Peace Corps, Overseas Press reaction, April 20, 1961".

Documento 102: Nara II, RG 306, Declassified NND 988085, US Information Agency; Office of Research and Media Reaction; Research Memoranda; 1963-1999, M-215-1963 THRU M-330-1963, 1954 to Security Reports, 1968-1971, Stack area 230, Row 046, compartment 19, Shelf 3, Entry P-64, 
Box 3, ARC 4778251, "Brazilian Press View on the Crisis, 1963”, "Brazilian Catholics Quarantine Tito, 1963”.

Documento 103: Nara II, RG 306, Declassified NND 988085, US Information Agency; Office of Research and Media Reaction; Research Memoranda; 1963-1999, M-1-1964 THRU M-101-1964, Stack area 230, Row 046, compartment 19, Shelf 3, Entry P-64, Box 5, ARC 4778251, "Brazil Leading Newspaper praises President Johnson, 1964".

Documento 104: Nara II, RG 306, Declassified NND 008024, RECORDS OF THE UNITED STATES INFORMATION AGENCY (USIA); Subject Files; 1953-1967, Stack area 230, Row 46, compartment 17, Shelf 1, Entry A1-56, Box 56.

Documento 105: Nara II, RG 306, Declassified NND 36854, General Records of the United States Information Agency (USIA); Historical Collection, SUBJECT FILES; 1953-2000, Portuguese and Spanish Translations of U.S. Books, 1950-1966 to Selections of Titles, 1981-1987, Stack area 230, Row 047, compartment 6, Shelf 3, Entry A1-1066, Box 185, "Portuguese Translations of United States Books, 1950- 1963".

Documento 106: Nara II, RG 306, Declassified NND 37109, General Records of the United States Information Agency (USIA); Office of the Director, Historical Collection; REPORTS AND STUDIES, 1953-1998, Evaluation of the Exchange Program, 1950 to Evaluation of International Exchange Experiences of Brazilian Grantees, 1953, Stack area 230, Row 047, compartment 28, Shelf 3, Entry A1-1070, Box 31, NN3-306-02-003, "Evaluation of International Exchange Experiences of Brazilian Grantees, 1953".

Documento 107: NARA II, Still Pictures, RG 306, Box 81, photo 64-1555, "Rio de Janeiro, Brazil: Address labels from propaganda material direct from Moscow and peeking to a communist-dominates student organization, the União fluminense dos estudantes. The material was seized by authorities after the April Revolution. Source: USIS Brazil. 4/24/64 copy neg”.

Documento 108: Nara II, RG 306, Declassified NND 74640, RECORDS OF THE UNITED STATES INFORMATION AGENCY (USIA); Information Center Service/English Teaching Division/Country Files; 1955-1965, Lebanon-E.T. THRU Chile E.T.; Stack area 131, Row 16, compartment 20, Shelf 4, Entry P-79, Box 8 ARC 4750923, "General view of overflow audience on occasion of graduation ceremony at BNC Belo Horizonte. December 1st, 1962", "Student program: UNE-Sponsored Seminar on Northeast Problems".

Documento 109: Nara II, RG 306, Declassified NND 988085, US Information Agency; Office of Research and Media Reaction; Research Memoranda; 
1963-1999, M-123-63 THRU M-214-1963, Stack area 230, Row 046, compartment 19, Shelf 3, Entry P-64, Box 2, ARC 4778251, "Agitation and Public Opinion in Crucial Areas of Northeast Brazil, 1963”.

Documento 110: Nara II, RG 306, Declassified NND 988085, RG 306, Records of the United States Information Agency, Office of Research and Media Reaction; Research Memoranda; 1963-1999, January 1963 THRU M-79-63, Stack area 230, Row 046, compartment 19, Shelf 03-, Entry P-64, Box 1, ARC 4778251, "M-63-63, "USIA Comments on the First Working DraftTraining of Latin Americans in the United States, April 11, 1963”.

Documento 111: Nara II, RG 306, Declassified NND 988085, RECORDS OF THE UNITED STATES INFORMATION AGENCY (USIA); Office of Research; Research Reports, 1960-1999, R-216-63 THRU R-25-64; Stack area 230, Row 48, compartment 26, Shelf 3, Entry P-142, Box 18 ARC 5637789, "Peasants Attitudes in Northwest Brazil, February 14, 1964".

Documento 112: Nara II, RG 306, Declassified NN3-306-02-003, General Records of the United States Information Agency, Office of Administration; Historical Collection, Murray Lawson History Card Files Series; 1953-1975, USIA Personnel Issues, 1953-1975 to USIA Personnel Issues, 1953-1975, Stack area 230, Row 047, compartment 26, Shelf 6, Entry A1-1055, Box 38, "1954- : Streitbert/Logan - USIA cartoon strips are unattributed", "1969: Usia's renewed interest in town affiliation program".

Documento 113: Nara II, RG 306, Declassified NND 36854, General Records of the United States Information Agency (USIA); Historical Collection, SUBJECT FILES; 1953-2000, Arts America, 1968-1998 to Arts America, 1968-1998, Stack area 230, Row 047, compartment 6, Shelf 3, Entry A11066, Box 169, "Arts America, Latin America, '55 - 63”".

Documento 114: Nara II, RG 306, Declassified NND 988085, stack area 230, row 046, compartment 024, shelf 6, Office of Research, Special reports, 195559, -11; Media Briefs, 1961-62, -13, Box 1 Entry (A1) 1012, "Music USIA, 50's-60's'.

Documento 115: Nara II, RG 306, Declassified NND 988085, Records of the United States Information Agency, Office of Research and Analysis; Research Reports; 1956-1959, 1957: P-35.1 THRU 1957: P-75, Stack area 230, Row 046, compartment 36, Shelf 05-06, Entry A1-1033, Box 3, ARC 1074148, "P-57-57, Latin American Communist preparation dor the Moscow Youth Festival, June 21, 1957”.

Documento 116: Nara II, RG 306, Declassified NND 36854, General Records of the United States Information Agency (USIA); Historical Collection, SUBJECT FILES; 1953-2000, Cultural Programming, Latin America, 
1938-1966 to Cultural Programming, International Cultural Relations in Europe, 1997-1998, Stack area 230, Row 047, compartment 6, Shelf 3, Entry A1-1066, Box 188, "City Welcomes Philharmonic Home", "Rio Visit is ended by Philharmonic".

Documento 117: Nara II, RG 306, Declassified NND 74610, RECORDS OF THE UNITED STATES INFORMATION AGENCY (USIA); Information Center Service/Exhibitions Division/Records Relating to International Trade Fairs; 1951-1966, Lima Trade Fair fall 1959, 1961 THRU São Paulo Air Show (Spring 63); Stack area 131, Row 39, compartment 11, Shelf 1, Entry P-33, Box 3 ARC 4705668, "Rio Solo Exhibition, Fall 1963, São Paulo Space Fair, Spring 1963”.

Documento 118: Nara II, RG 306, Declassified NND 74610, RECORDS OF THE UNITED STATES INFORMATION AGENCY (USIA); Information Center Service/Exhibitions Division/Records Relating to International Trade Fairs; 1951-1966, Paris Air Show Spring 63 THRU Tokyo 1963 Photos; Stack area 131, Row 39, compartment 11, Shelf 2, Entry P-33, Box 9 ARC 4705668, "Photos Rio exhibition 1963".

Documento 119: Nara II, RG 306, Declassified NND 008024, RECORDS OF THE UNITED STATES INFORMATION AGENCY (USIA); Subject Files; 1953-1967, Stack area 230, Row 46, compartment 16, Shelf 4, Entry A1-56, Box 39, "San Leandro, California Desires Brazilian Affilitation".

Documento 120: Nara II, RG 306, Declassified NND 008024, RECORDS OF THE UNITED STATES INFORMATION AGENCY (USIA); Subject Files; 1953-1967, Stack area 230, Row 46, compartment 16, Shelf 4, Entry A1-56, Box 37, "Barbacena tem uma irmã no meio-oeste americano, 13/8/1963".

Documento 121: Nara II, RG 306, Declassified NND 008024, RECORDS OF THE UNITED STATES INFORMATION AGENCY (USIA); Subject Files; 1953-1967, Stack area 230, Row 46, compartment 16, Shelf 4, Entry A1-56, Box 38, "People to People da cidade do Salvador-Programa de Amizade de Povo para Povo, Los Angeles-Bahia, Estados Unidos-Brasil, October 31st, 1963".

Documento 122: Nara II, RG 306, Declassified NND 008024, RECORDS OF THE UNITED STATES INFORMATION AGENCY (USIA); Subject Files; 1953-1967, Stack area 230, Row 46, compartment 17, Shelf 1, Entry A1-56, Box 47, "Request for information - Institute of Engineers - São Paulo State, September 19, 1963".

Documento 123: Nara II, RG 306, Declassified NND 36854, General Records of the United States Information Agency (USIA); Historical Collection, 
SUBJECT FILES; 1953-2000, People to People Program, 1956-1962 to People to People Program, 1956-1962, Stack area 230, Row 047, compartment 6, Shelf 3, Entry A1-1066, Box 201, "Town Affiliation News, November $1965 "$.

Documento 124: Nara II, RG 306, Declassified NND 36854, General Records of the United States Information Agency (USIA); Historical Collection, SUBJECT FILES; 1953-2000, Broadcasting to Africa, 1954-1997 to Broadcasting to Latin America, 1953-1987, Stack area 230, Row 047, compartment 6, Shelf 3, Entry A1-1066, Box 70, "Voice concludes Spanish programs, May, 1953”, "VOA adds for Brazil, 1961".

Documento 125: Nara II, RG 306, Declassified NN3-306-02-003, General Records of the United States Information Agency, Office of Administration; Historical Collection, Murray Lawson History Card Files Series; 1953-1975, USIA News Programs, 1953-1975 to USIA Programs, 1953-1975, Stack area 230, Row 047, compartment 26, Shelf 6, Entry A1-1055, Box 39, "1954: Lemmon- WRUL broadcasts to Brazil began in March".

Documento 126: Nara II, RG 306, Declassified NND 988085, RECORDS OF THE UNITED STATES INFORMATION AGENCY (USIA); Office of Research; Special Reports (S), 1953-1997, S-13-54 THRU S-27-54 (vol.1); Stack area 230, Row 48, compartment 27, Shelf 4, Entry P-160, Box 5 ARC 5664216, "Geographic distribution of Radio Sets and Characteristics of Radio Owners in Countries Around the World, 1954".

Documento 127: Nara II, RG 306, stack area 230, row 046, compartment 24, shelf 5, Declassified NND 988085, Entry 1011, Box, U.S. Information Agency, Office of Research and Analysis, Entry A1 1011: Program and Media Studies; 1956-1962, PMS-1 THRU PMS-45, Container, Arch101846, "PMS-21, Radio listening in some Latin American Countries, November 29, 1957".

Documento 128: Nara II, RG 306, Declassified NND 36844, General Records of the United States Information Agency, Bureau of Programs; Historical Collection, Records relating to select USIA Programs; 1953-1999, Latin American Program, 1961 to Afghan Media project, 1985-1988, Stack area 230, Row 047, compartment 1, Shelf 1, Entry A1-1061, Box 14, "USIA Support for the "Alliance for Progress", November, 1961".

Documento 129: Nara II, RG 306, Declassified NN3-306-02-003, General Records of the United States Information Agency, Office of Administration; Historical Collection, Murray Lawson History Card Files Series; 1953-1975, USIA Programs, 1953-1975 to USIA Programs, 1953-1975, Stack area 230, Row 047, compartment 26, Shelf 6, Entry A1-1055, Box 41, "USIA sending 
untranslated TV programs to 21 countries", "1957: description of USIA's Washington TV program".

Documento 130: Nara II, RG 306, Declassified NND 988085, Records of the United States Information Agency, Office of Research and Intelligence, Intelligence Bulletins, memorandums and Summaries; 1954-1956; 1956: IS-5 thru 1956: IS-30, Stack area 230, Row 046, compartment 035, Shelf 01, Entry A1-1022, Box 7, ARC 1073965, "IS-28-56, Overseas Television Developments, quarterly report, March 30, 1956".

Documento 131: Nara II, RG 306, Declassified NND 988085RG 306, Records of the United States Information Agency, Office of Research and Analysis; Research Reports; 1956-1959, 1956: P-127 THRU 1957: P1.6, Stack area 230, Row 046, compartment 36, Shelf 05 - 06, Entry A1-1033, Box 1, ARC 1074148, "P-128-56, Overseas Television Developments, 1956".

Documento 132: Nara II, RG 306, Declassified NND 988085, Records of the United States Information Agency, Office of Research and Analysis; Research Reports; 1956-1959, 1957: P-1.7 THRU 1957: P-34, Stack area 230, Row 046, compartment 36, Shelf 05-06, Entry A1-1033, Box 2, ARC 1074148, "P-23-57, Overseas Television Developments - Quarterly Report, January-March, 1957".

Documento 133: Nara II, RG 306, Declassified NND 988085, Records of the United States Information Agency, Office of Research and Analysis; Research Reports; 1956-1959, 1957: P-76 THRU 1958: P-2.1, Stack area 230, Row 046, compartment 36, Shelf 05-06, Entry A1-1033, Box 4, ARC 1074148, "P-91-57, Overseas Television Developments - Quarterly Report, July-September 1957".

Documento 134: Nara II, RG 306, Declassified NND 988085, stack area 230, row 046, compartment 024-25, shelf 7-1, Records of the U.S. Information Agency, Office of Research, Country Project Files, 1951-1964, Brazil, 1961 to Brazil, 1963, Box 13 ARC ID 1065787, A1, Entry 1015, "BR 6301, American TV Viewing, Jan-Feb 1963".

Documento 135: Nara II, RG 306, Declassified NND 988085, RECORDS OF THE UNITED STATES INFORMATION AGENCY (USIA); Office of Research; Research Reports, 1960-1999, R-11-63 THRU R-50-63; Stack area 230, Row 48, compartment 26, Shelf 3, Entry P-142, Box 13 ARC 5637789. "Overseas Television Developments in 1962".

Documento 136: Nara II, RG 306, Declassified NND 022120, RECORDS OF THE UNITED STATES INFORMATION AGENCY (USIA); Movie Scripts, 1942-1965; Stack area 230, Row 047, compartment 17, Shelf 5, Entry A1-1098, Box 34, "President Dutra's Visit to USA, 1949". 
Documento 137: Nara II, RG 306, Declassified NND 022120, RECORDS OF THE UNITED STATES INFORMATION AGENCY (USIA); Movie Scripts, 1942-1965; Stack area 230, Row 047, compartment 17, Shelf 1, Entry A1-1098, Box 3, "Atomic Medicine in Brazil, 1954".

Documento 138: Nara II, RG 306, Declassified, US Information Agency; Office of Research and Reference/ Agency Library; International Survey Research Reports; 1953-1964, IRI BR 37 - IRI BR 40: Media Habits in Selected Brazilian Cities - Public Opinion Surveys - January, 1957 THRU IRI BR 66: U.S. Assistance, Trade and Private Companies - Public Opinion Surveys March 1959, Stack area 230, Row 47, compartment 22, Shelf 4, Entry P-78, Box 13, ARC 721251, "Audience Reaction to Quero Saber Mais, 1957".

Documento 139: Nara II, RG 306, Declassified NND 988085, stack area 230, row 046, compartment 024-25, shelf 7-1Records of the U.S. Information Agency, Office of Research, Country Project Files, 1951-1964, Brazil, 1959 to Brazil, 1960, Box 10, ARC ID 1065787, A1, Entry 1015, BR 5901, Brazil, "Film Study: Now the School is different, apr. 1959".

Documento 140: Nara II, RG 306, Declassified NND 37109, General Records of the United States Information Agency (USIA); Office of the Director, Historical Collection; BIOGRAPHICAL FILES RELATING TO USIA DIRECTORS AND OTHER SENIORS OFFICIALS, 1953-2000, Edward R. Murrow, "Harvest of Shame", 1961, to Edward R. Murrow, Jonas Salk, 1962, Stack area 230, Row 047, compartment 12, Shelf 3, outcard 3, Entry A1-1069, Box 18, NN3-306-02-003, "Cinegráfica São Luiz S.A., January, 1962". 
SOBRE O LIVRO

Formato: $14 \times 21 \mathrm{~cm}$

Mancha: $23,7 \times 42,5$ paicas

Tipologia: Horley Old Style 10,5/14

Papel: Offset $75 \mathrm{~g} / \mathrm{m}^{2}$ (miolo)

Cartão Supremo $250 \mathrm{~g} / \mathrm{m}^{2}$ (capa)

1a edição: 2015

EQUIPE DE REALIZAÇÃO

Coordenação Geral

Marcos Keith Takahashi 